\title{
25. PETROLOGIC EVOLUTION OF LAU BASIN SITES 834 THROUGH 839¹
}

\author{
James W. Hawkins ${ }^{2}$ and James F. Allan ${ }^{3}$
}

\begin{abstract}
Ocean Drilling Program Leg 135 provided igneous rock cores from six sites drilled on a transect across the Lau Basin between the Lau Ridge remnant arc and the modern spreading ridges of the Central and Eastern Lau Spreading Centers. The drill cores sampled crust from the earliest stage of backarc extension (latest Miocene time, about $6 \mathrm{Ma}$ ), and younger crust (late Pliocene, about 3.8-2 Ma, and middle Pleistocene, about $0.64-0.8 \mathrm{Ma}$ ). Nearly all of the igneous samples are from tholeiitic basalt flows; many of them are interbedded with arc-composition volcaniclastic sediments. Rock compositions range from olivine-plagioclaseclinopyroxene basalt, with up to $8 \% \mathrm{MgO}$, to oceanic andesites with less than $3.2 \% \mathrm{MgO}$ and silica contents as high as $56 \%$. The oldest rocks recovered are close in composition to rocks formed at the modern Central and Eastern Lau Spreading Centers and have MORB-like characteristics. Generation of the oldest units was coeval with arc-tholeitic volcanism on the Lau Ridge less than $100 \mathrm{~km}$ to the west. The arc and backarc melts came from different mantle sources. At three sites near the center of the basin, the crust is arc-tholeiitic basalt, two-pyroxene basaltic-andesite, and two-pyroxene andesite. These rocks have many similarities to modern Tofua Arc lavas yet they were drilled within $70 \mathrm{~km}$ of the MORB-like Eastern Lau Spreading Center. Estimates of the minimum age for these arc-like rocks indicate that they are late Pliocene (about $2 \mathrm{Ma}$ ). These ages overlap the age of the nearby Eastern Lau Spreading Center.

The heterogeneous crust of the Lau Basin carries many of the signatures of supra-subduction zone (SSZ) melts but also has a distinct MORB-like component. Mixing between SSZ and MORB mantle sources may explain the variations and the spatial distribution of magma types.
\end{abstract}

\section{INTRODUCTION}

The Lau Basin and its adjacent island-arc systems are located at a major plate convergence zone marked by the Tonga Trench. A major objective for Ocean Drilling Program (ODP) Leg 135 was to sample the Lau Basin crust on a transect between the remnant volcanic arc (the Lau Ridge) and the modern seafloor-spreading centers in the backarc basin. The goals included (1) dating the inception of opening of the basin and the beginning of Lau Basin magmatism, (2) learning the composition of the earliest magmatism to compare it to the modern spreading centers and island arcs, and (3) looking for evidence of temporal or spatial variation in magma chemistry in response to opening of the basin.

Intraoceanic convergent plate margins are major sites of crustal generation in ocean basins second in importance only to the mid-ocean ridges. Here, magmas derived by partial melting of supra-subduction zone (SSZ) mantle and small amounts of subducted oceanic lithosphere form new crust in the forearc, island-arc chains, and backarc basins. Much of the mantle source is older, previously melted and depleted mantle, but the stress fields set up during the subduction process no doubt give rise to mantle counterflow that allows introduction of more fertile mantle into the melting regime. Dehydration reactions in the subducted lithosphere generate fluids enriched in large ionic radius lithophile elements that permeate and metasomatize the previously depleted mantle wedge (e.g., Pearce et al., 1984; Tatsumi et al., 1986; Tatsumi, 1989). Partial melts of the subducted lithosphere also may replenish the depleted mantle wedge. Thus, the SSZ mantle may be quite heterogeneous.

A major focus of study for Leg 135 was the long-standing problem of the petrologic/tectonic controls on backarc magmatism, and the relationship between coeval arc and backarc magmatism. Under-

\footnotetext{
${ }^{1}$ Hawkins, J., Parson, L., Allan, J., et al., 1994. Proc. ODP, Sci. Results, 135: College Station, TX (Ocean Drilling Program).

${ }^{2}$ Geological Research Division, Scripps Institution of Oceanography, La Jolla, CA 92093-0220, U.S.A.

${ }^{3}$ Ocean Drilling Program, 1000 Discovery Drive, Texas A\&M University, College Station, TX 77845-9547, U.S.A.
}

standing these processes has implications to the nature of mantle sources for magmas and to magmatic processes in arc, backarc, and forearc settings. It also can give insight to the nature of tectonic processes that form these wide zones of crustal extension at convergent intraoceanic plate margins.

The main petrologic objective addressed at Sites 834 through 839 was to understand the petrology of the magmas formed in the earliest stages of extensional deformation of the Lau Basin. The plan was to sample the region west of the modern spreading centers in order to look for spatial and temporal zonation in magma types. The drilling would give samples of crust buried by sediment, provide paleontologic and stratigraphic control on crustal age, and give deep samples of igneous rocks that would give information about temporal compositional evolution at each site. A detailed discussion of Leg 135 drilling objectives is in the Initial Reports volume (Parson, Hawkins, Allan, et al., 1992).

This report uses the drill-core data to discuss the petrology and chemistry of rocks formed during the first 4-5 m.y. of Lau Basin extension. Six backarc sites were drilled (Fig. 1), but we focus mainly on the petrology of Sites $834,835,836$, and 839 as only limited material was recovered at Sites 837 and 838 . In the following sections, we give a brief description of the regional geology to provide the background for our new data and for other contributions in this volume; we then discuss the petrology and chemistry of the backarc drill sites; and we compare the data with the modern Tofua island arc and rocks formed at the axial ridges in the Lau Basin during the last 1-2 m.y.

This report complements other detailed descriptions of Sites 834 and 839 (Hergt and Nilsson, Hergt and Hawkesworth, and Ewart et al.; all in this volume). A synthesis of the Leg 135 petrologic data (Hawkins, this volume) discusses models for petrogenesis. Adetailed petrographic discussion of the samples recovered and a summary of the geochemical data collected aboard ship are in the Initial Reports volume (Parson, Hawkins, Allan, et al., 1992).

\section{SUMMARY OF TECTONIC SETTING}

The Lau Basin occupies a trapezoidal shaped rift that has separated the Lau and Tonga ridges during the last 6 m.y. (Karig, 1970; Hawkins, 1974). The basin is situated above a well-defined Wadati-Benioff Zone 


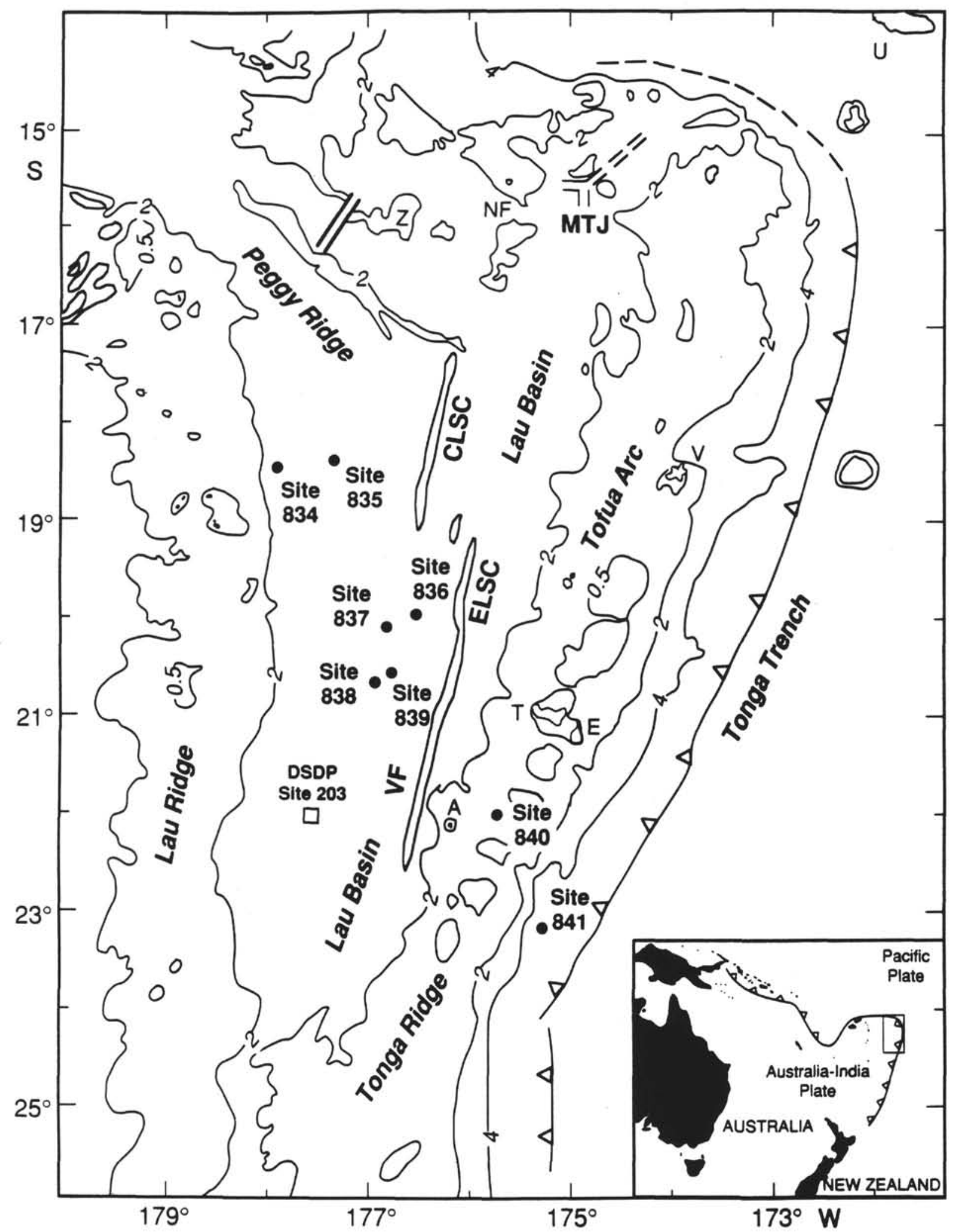

Figure 1. Regional setting for Leg 135 Sites 834 through 839 discussed in this paper as well as the locations of the other Leg 135 sites. Shown are the Tonga Trench, Lau Basin, and Lau Ridge. Other features are the Central Lau (CLSC) and Eastern Lau (ELSC) spreading centers, Mangatolu Triple Junction (MTJ), Valu Fa Ridge (VF), and Zephyr Shoal (Z). Islands shown are Upolu (U), Western Samoa, Tongatapu (T), 'Eua (E), Vava'u (V), 'Ata (A), and Niuafo'ou (NF). Depth contours in kilometers. 
that marks the location of the subducted Pacific Plate. Cretaceous age Pacific Plate lithosphere is being subducted into the Tonga Trench beneath the Indo-Australian Plate at rates estimated to range from 10.5 $\mathrm{cm} / \mathrm{yr}$ (Minster and Jordan, 1978) to as much as $17.8 \mathrm{~cm} / \mathrm{yr}$ (Pelletier and Louat, 1989) depending on the latitude. The upper surface of the seismic zone lies at a depth of about $140 \mathrm{~km}$ below the active volcanoes of the Tofua (Tonga) Arc and is about $250 \mathrm{~km}$ under the Central Lau Spreading Center (CLSC) and Eastern Lau Spreading Center (ELSC) (Isacks and Barazangi, 1977). A broad zone of strong seismic wave attenuation was recognized west of the Tonga Ridge beneath the Lau Basin by Barazangi and Isacks (1971) who attributed it to high temperature or partial melting in the mantle. The upper trace of the seismic zone has been modeled as an irregular and strongly curved surface (Billington, 1980). It terminates at its northern end where the Tonga Trench curves sharply to the west and the plate boundary becomes a transform fault boundary between the Tonga and New Hebrides-Vanuatu trenches. An inflection in the seismic zone at depths of 525-575 $\mathrm{km}$, first identified by Billington (1980), was interpreted as the result of imbrication of the subducted lithosphere by Louat and Dupont (1982) who estimated that the lithosphere at the depth of this inflection was subducted about 7-8 m.y. ago. This is close to the 6-Ma age estimated for beginning of opening of the Lau Basin (Parson, Hawkins, Allan, et al., 1992); the two events may be related.

Attempts to model Lau Basin crustal structural fabric, and ages of magnetic lineations, in terms of plate tectonic theory have met with only limited success because the magnetic data have proved difficult to interpret. The western part of the basin lacks a continuous magnetic fabric and symmetric anomalies cannot be traced beyond the region near the axial ridges (e.g., Lawver et al., 1976; Lawver and Hawkins, 1978; Weissel, 1977). Previous interpretations of the age of the earliest backarc crust in the Lau Basin vary from 5-10 Ma (Sclater et al., 1972) to 2.5-3 Ma (Malahoff et al. 1982).

Data from Site 834 demonstrate that rifting started before $5.6 \mathrm{Ma}$; we estimate that it may have started by about $6 \mathrm{Ma}$. The early backarc crustal extension was contemporaneous with volcanism on the Lau Ridge (e.g., 4.5-2.5 Ma basalts of the Korobasaga Group). Whelan et al. (1985) recognize an "early rifting stage" that occurred late in the evolution of the Lau Ridge; they correlate the Korobasaga Group with this rifting. The arc rifting and eruption of the Korobasaga Group, which was dominated by tholeiitic basalt, overlaps with beginning of crustal extension in the western Lau Basin but predates the time inferred for the beginning of seafloor spreading.

Presently, the Lau Basin appears to be opening in an east-west direction by symmetric seafloor spreading on well-defined, but segmented and offset, axial ridges aligned along longitude $176^{\circ} 30^{\prime} \mathrm{W}$. The seafloor spreading represents a second stage of basin opening that may have started at about 4.5-5.0 Ma. Parson and Hawkins (this volume) propose that true seafloor spreading began by southward propagation of a rift that started on the trace of the Peggy Ridge; this propagator formed the present ELSC. Thus the age of crust formed by seafloor spreading is progressively younger to the south. This age pattern is further complicated by the development of a second propagator that has cut through the older (ELSC) seafloor and has formed the present CLSC (Parson et al., 1989, 1990; Parson, Hawkins, Allan, et al., 1992; Parson and Hawkins, this volume). The two spreading centers overlap and are separated by complex seafloor with traces of pseudo-faults and an abandoned intermediate ridge or relay zone.

\section{REGIONAL GEOLOGIC SETTING}

A comprehensive discussion of the geologic setting and history of the Lau Basin region is in Parson, Hawkins, Allan, et al. (1992); here we summarize some of the key points:

1. The Lau Ridge was an active volcanic island arc from at least 14.0-2.5 Ma (Cole et al., 1985). Volcanic activity younger than 2.5
Ma appears to have been related to extensional stresses to the rear of the arc and backarc rather than to frontal arc volcanism.

2. The geologic history of the Lau Ridge may extend back to late Eocene time as suggested by the occurrence of Eocene arc volcanic rocks on Viti Levu, Fiji Islands (Wharton et al., 1992) and Eocene arc plutonic rocks on 'Eua, in the Tonga forearc (Ewart and Bryan, 1972; Cunningham and Anscombe, 1985). Leg 135 drilling at Site 841 (Parson, Hawkins, Allan, et al., 1992; Bloomer, this volume) also revealed pre-late Eocene and late Miocene arc series volcanic rocks on the Tonga Ridge. All of these rocks are interpreted as remnants of a former "Melanesian island arc" that included what are now parts of the Lau Ridge, Tonga Ridge, Fiji Platform, and New Hebrides-Vanuatu Ridge (Woodhall, 1985; Cole et al., 1985).

3. The Lau Basin began to open in latest Miocene time (about 6 Ma) as the eastern part of the Lau Ridge and its forearc were rifted away to the east. Fragments of the Lau Ridge and its older basement are found on the Tonga Ridge.

4. There has been more or less continuous arc volcanism in the Lau-Tonga region since late Eocene time. Lau Ridge volcanism overlapped with the time of initial crustal extension that formed the Lau Basin, but during the last $2.5 \mathrm{Ma}$ it has diminished and seafloor spreading in the Lau Basin has supplanted it. Within the last 1 m.y. the Tofua Arc has become a major feature on the Tonga Ridge.

5. Lau Basin crust is largely floored by basaltic rocks having MORB (mid-ocean-ridge basalt) mineralogy and many MORB-like chemical and isotopic characteristics. The Central Lau and Eastern Lau spreading centers (Fig. 1) are well-defined axial ridge systems formed mainly of N-MORB type basalts (e.g., Hawkins, 1974, 1976, 1977, 1988, 1989; Hawkins and Melchior, 1985, Hawkins et al., 1989; Volpe et al., 1988; Sunkel, 1990; Loock et al., 1990; Ernewein et al., in press).

6. Although dominated by MORB-like chemistry, the crust of the Lau Basin, like other backarc basins, is heterogeneous. Hawkins and Melchior (1985) proposed that the Lau Basin was compositionally zoned from older "transitional to arc" rocks to younger MORBlike rocks. Seamounts in the northern Lau Basin include rocks having an ocean island basalt composition component (Volpe et al., 1988), and dacitic rocks of Zephyr Shoal (Hawkins, 1976) that appear to be silicic differentiates of boninite magma series. Rocks having a strong arc signature are found on the Valu Fa Ridge (Jenner et al., 1987; Vallier et al., 1991), and the Mangatolu Triple Junction (Nilsson et al., 1989; Nilsson, 1993) includes a range in rock types from basaltic to basaltic andesite.

Sites 834,835 , and 836 (Fig. 1), although not on a true "flow line" in the sense of progressive accretion of new crust, sampled the evolution of magma types over a time span of about $5 \mathrm{~m} . \mathrm{y}$. The sites are located, respectively, on the oldest crust drilled (about 5.6 Ma, latest Miocene), intermediate age crust (about $3.4 \mathrm{Ma}$, late Pliocene), and the youngest crust drilled (about $0.64-0.80 \mathrm{Ma}$, middle Pleistocene). Site 836 lies about $50 \mathrm{~km}$ west of the axis of the ELSC, which comprises both MORB-like tholeiite and rocks having a composition transitional from MORB to arc tholeiite (e.g., Hawkins and Melchior, 1985; Ernewein et al., in press). Sites 837,838 , and 839 form a cluster, about $125 \mathrm{~km}$ west of the active ELSC, on crust estimated to be 1.9, 2.0, and $2.1 \mathrm{Ma}$, respectively. An extensive description of each drill site is given in Parson, Hawkins, Allan, et al., 1992; site locations and depths are in Table 1.

\section{SAMPLES AND ANALYTICAL PROCEDURES}

We present new data for 175 samples selected from the drill cores to complement the major and trace element data collected with the shipboard X-ray fluorescence (XRF) system. The shipboard data for representative samples from each of the petrographic units recognized aboard ship are in the Initial Reports volume (Parson, Hawkins, Allan, et al., 1992). The new data presented here include glass, bulk-rock, 
Table 1. Drill-site locations.

\begin{tabular}{|c|c|c|c|}
\hline Hole & Latitude & Longitude & $\begin{array}{l}\text { Water depth } \\
\text { (m) }\end{array}$ \\
\hline Hole $834 \mathrm{~A}$ & $18^{\circ} 34.058^{\prime} \mathrm{S}$ & $177^{\circ} 51.735^{\prime} \mathrm{W}$ & 2692.3 \\
\hline Hole 834B & $18^{\circ} 34.052^{\prime} \mathrm{S}$ & $177^{\circ} 51.737^{\prime} \mathrm{W}$ & 2688.4 \\
\hline Hole $835 \mathrm{~A}$ & $18^{\circ} 30.061^{\prime} \mathrm{S}$ & $177^{\circ} 18.162^{\prime} \mathrm{W}$ & 2905.7 \\
\hline Hole $835 \mathrm{~B}$ & $18^{\circ} 30.050^{\prime} \mathrm{S}$ & $177^{\circ} 18.192^{\prime} \mathrm{W}$ & 2905.6 \\
\hline Hole 836A & $20^{\circ} 08.494^{\prime} \mathrm{S}$ & $176^{\circ} 30.008^{\prime} \mathrm{W}$ & 2466.3 \\
\hline Hole 836B & $20^{\circ} 08.505^{\prime} \mathrm{S}$ & $176^{\circ} 30.011^{\prime} \mathrm{W}$ & 2468.5 \\
\hline Hole 837A & $20^{\circ} 13.307^{\prime} \mathrm{S}$ & $176^{\circ} 49.362^{\prime} \mathrm{W}$ & 2752.5 \\
\hline Hole 837B & $20^{\circ} 13.319^{\prime} \mathrm{S}$ & $176^{\circ} 49.362^{\prime} \mathrm{W}$ & 2753.0 \\
\hline Hole 838A & $20^{\circ} 49.618^{\prime} \mathrm{S}$ & $176^{\circ} 53.402^{\prime} \mathrm{W}$ & 2322.8 \\
\hline Hole 838B & $20^{\circ} 49.629^{\prime} \mathrm{S}$ & $176^{\circ} 53.402^{\prime} \mathrm{W}$ & 2333.8 \\
\hline Hole 839A & $20^{\circ} 41.531^{\prime} \mathrm{S}$ & $176^{\circ} 46.492^{\prime} \mathrm{W}$ & 2617.4 \\
\hline Hole 839B & $20^{\circ} 42.539^{\prime} \mathrm{S}$ & $176^{\circ} 46.501^{\prime} \mathrm{W}$ & 2617.3 \\
\hline
\end{tabular}

and mineral analyses collected by a combination of electron microprobe (EMX), XRF, and instrumental neutron activation analysis (INAA) techniques. Major element data for glasses from chilled margins of pillows and flows were collected by EMX using the SIO Cameca CAMEBAX electron probe microanalyzer with three wavelength-dispersive spectrometers. Running conditions were $15 \mathrm{kv}, 15$ $\mathrm{nA}$ sample current on brass, and a 10-m spot size. Standards used were a combination of mineral and glass standards; data were normalized to Smithsonian Institution basalt glass standard VG-2. The EMX mineral analyses were normalized to mineral standards.

Bulk-rock XRF analyses were made on glass discs fused with lithium metaborate flux and lanthanum heavy absorber (for major elements) or pressed discs of rock powder and a cellulose binder (for trace elements). Major elements were analyzed with a Sc tube ( $40 \mathrm{kv}$, $40 \mathrm{~mA})$ and trace elements with a W tube $(40 \mathrm{kv}, 45 \mathrm{~mA})$ using a Philips AXS X-ray spectrometer. Samples were crushed with alumina equipment to avoid contamination with elements of interest. Details of sample preparation procedure and XRF running conditions are in Bloomer et al. (1985). The INAA analyses were made on bulk-rock powders split from samples analyzed by shipboard XRF. The glass data represent liquid compositions with minimal contamination by phenocrysts or alteration material. The probe data are considered to be free of contamination. The glass was collected where preserved in the core; however, because of the extensive loss of glass in the drilling process, the stratigraphic distribution is spotty. There are sufficient data from glass to give a general picture of the downhole variations in magma chemistry, but much of the detail is lost because of the relatively poor recovery. The bulk-rock data are much better in terms of representing compositional stratigraphy although they are not truly liquid compositions. We attempted to select aphyric to very sparsely phyric samples from each unit and from various depth levels within them. For several samples we have data both for the glassy margin and the aphyric rock a few centimeters beneath it. These serve to show that, except for some of the porphyritic Site 839 samples, the differences between glass and contiguous aphyric samples is minimal. Thus, the bulk-rock data give a fairly reliable indication of magma evolution.

Bulk-rock INAA were made at Texas A\&M University using the campus TRIGA reactor for irradiation. Counting was done with facilities in the Center for Chemical Characterization. Samples were run in duplicate (both irradiation and counting) with $2 \mathrm{hr}$ counts obtained at 7-12 days, 28-33 days, and 4 months. Lead-shielded, high-resolution Ortec coaxial intrinsic germanium detectors, with efficiencies of $22 \%$ $24 \%$ relative to a $3 \times 3 \mathrm{in}$. NaI detector crystal at a distance of $25 \mathrm{~cm}$, and resolutions of $1.64-1.68 \mathrm{KeV}$ at FWHM of the $1332 \mathrm{KeV}$ line of ${ }^{60} \mathrm{Co}$ were used in the analysis procedure. Dead time was kept below $5 \%$ during counting. The NBS standard fly ash SRM 1633A was used as the multiple element standard (Korotev, 1987), with its Tb content corrected to $2.53 \mathrm{ppm}$ (R.L. Korotev, pers. comm., 1991). Spectral analysis and peak-height evaluation were made using a software package by Nuclear Data with U- and Th-series overlap and interference corrections done by hand (Glascock et al., 1986; Landsberger, 1986; Landsberger and Simsons, 1987).

Both the glass and bulk-rock data are complemented by microprobe data for the crystalline phases present at various levels within the rock columns sampled. These data are used both to characterize melt chemistry further and to model magma evolution by fractional crystallization. Silicate minerals were analyzed on the SIO microprobe. Spinel and magnetite analyses were made on the Texas A\&M Cameca SX50 automated four-spectrometer microprobe using 20-30 $\mathrm{s}$ counting times and a $1-\mu \mathrm{m}$ focused beam. International oxide standards were used. Si and $\mathrm{Ca}$ were counted for $10 \mathrm{~s}$ and are used primarily as a check for beam overlap on surrounding glass or silicate minerals. Corrections for Ti overlap on $\mathrm{V}$ were made by noting $\mathrm{V}$ count rates on Ti metal and V-free rutile.

\section{DISCUSSION OF THE DATA}

Our discussion focuses mainly on the petrology of samples cored at Sites 834, 835, 836, and 839. Data for these samples and those from Sites 837 and 838 are compared with other Lau Basin samples, especially from the CLSC and ELSC, and with rocks from the nearby volcanic arcs. Locations of the drill sites are shown in Figure 1; depths and coordinates are in Table 1. Major and trace element data for glasses and bulk-rock samples from the drill sites are summarized in Tables 2 and 3; INAA trace element data are in Table 4. The complete data are in Appendixes A and B. Comparative data for other parts of the Lau Basin are in Table 5. Mineral data are illustrated in Figure 2 and listed in Appendixes C-G. Complete descriptions of the geologic setting for each drill site and petrographic descriptions of the various rock units are in Parson, Hawkins, Allan, et al. (1992).

\section{Site 834}

\section{Introduction}

One of the major petrologic objectives at Site 834 was to determine the sequence of magmatic events associated with the earliest stages of opening of the Lau Basin. The site is in a small basin (about $2700 \mathrm{~m}$ deep) adjacent to the eastern flank of the Lau Ridge, some $100 \mathrm{~km}$ east of the axis of the ridge crest. This basin is one of several narrow, discontinuous, partly sedimented grabens or half-grabens that trend in a northerly direction nearly parallel to the Lau Ridge. These graben-like structures dominate the seafloor of the western Lau Basin and make a striking contrast with the morphology of the seafloor near the active spreading centers. We use the informal term "western extensional basin province" (WEB) for this part of the Lau Basin. For further discussion see Parson and Hawkins (this volume) and Hawkins (this volume). Immediately to the east of Site 834, a broad, north-trending bathymetric high centered on $18^{\circ} 35^{\prime} \mathrm{S}, 177^{\circ} 25^{\prime} \mathrm{W}$, shoals to about $1650 \mathrm{~m}$ at its summit. We have no data for rocks forming this ridge. It may be a fragment rifted from the Lau Ridge or it may have formed at an extinct spreading ridge, abandoned after an eastward migration, or jump, of the backarc spreading axis. Sidescan sonar images of pervasive, northsouth linear features along its crest are interpreted as evidence for recent tectonism, and a number of scattered discrete, brightly backscattering areas of the seafloor could be recent lava flow. These features may mark the site either of waning activity on a spreading center or rejuvenation of magmatism (Parson, this volume). Drilling at Site 834 encountered basalt flows at $106.2 \mathrm{~m}$ below seafloor (mbsf) in Hole $834 \mathrm{~A}$ and at $112.6 \mathrm{mbsf}$ in Hole 834B. Presumed igneous basement was reached at 163 mbsf. The maximum depths drilled were 149.5 mbsf in Hole 834A and 435.7 mbsf in Hole 834B.

\section{Petrographic and Mineralogic Summary}

Thirteen igneous units (Table 6) were distinguished aboard ship on the basis of such petrographic criteria as phenocrysts and textures, 
Table 2. Representative glass analyses.

\begin{tabular}{|c|c|c|c|c|c|c|c|c|c|c|c|c|c|c|c|c|}
\hline $\begin{array}{l}\text { Core, section, } \\
\text { interval }(\mathrm{cm})\end{array}$ & Unit & $\mathrm{SiO}_{2}$ & $\mathrm{TiO}_{2}$ & $\mathrm{Al}_{2} \mathrm{O}_{3}$ & $\mathrm{FeO}^{*}$ & $\mathrm{MnO}$ & $\mathrm{MgO}$ & $\mathrm{CaO}$ & $\mathrm{Na}_{2} \mathrm{O}$ & $\mathrm{K}_{2} \mathrm{O}$ & $\mathrm{P}_{2} \mathrm{O}_{5}$ & Sum & $\mathrm{Mg} \#$ & $\mathrm{CaO} / \mathrm{Al}_{2} \mathrm{O}_{3}$ & $\begin{array}{c}\mathrm{Na}_{2} \mathrm{O} / \\
\left(\mathrm{Na}_{2} \mathrm{O} / \mathrm{CaO}\right) \\
\end{array}$ & $\mathrm{Na}_{2} \mathrm{O}_{8}$ \\
\hline \multicolumn{17}{|c|}{$135-834 \mathrm{~A}-12 \mathrm{X}-\mathrm{CC}, 2-4$} \\
\hline & 1 & 50.17 & 1.48 & 16.19 & 8.68 & 0.20 & 7.00 & 11.93 & 3.40 & 0.12 & 0.21 & 99.08 & 62.3 & 0.737 & 0.285 & 3.03 \\
\hline \multicolumn{17}{|c|}{$135-834 \mathrm{~A}-13 \mathrm{X}-1,18-24(\mathrm{~N})$} \\
\hline & 2 & 49.96 & 1.65 & 16.06 & 9.71 & 0.17 & 5.81 & 11.14 & 3.73 & 0.16 & 0.17 & 98.55 & 55.1 & 0.694 & 0.335 & 2.92 \\
\hline Mean (12) & 6 & 51.98 & 1.66 & 16.01 & 9.34 & 0.19 & 5.66 & 10.23 & 3.32 & 0.19 & 0.20 & 98.77 & 55.2 & 0.640 & 0.330 & 2.45 \\
\hline Mean (17) & 7 & 50.20 & 1.32 & 16.33 & 8.78 & 0.17 & 7.73 & 11.88 & 3.00 & 0.10 & 0.12 & 99.64 & 64.1 & 0.730 & 0.240 & 2.91 \\
\hline Mean (5) & 8 & 51.59 & 1.22 & 15.99 & 8.77 & 0.18 & 5.97 & 11.17 & 2.87 & 0.11 & 0.11 & 97.99 & 58.3 & 0.700 & 0.260 & 2.12 \\
\hline Mean (9) & $10 \mathrm{~A}$ & 53.35 & 1.80 & 15.28 & 10.74 & 0.22 & 4.40 & 8.80 & 3.22 & 0.27 & 0.21 & 98.29 & 45.6 & 0.580 & 0.370 & 1.88 \\
\hline \multicolumn{17}{|c|}{ 135-834B-46R-1, 37-40 } \\
\hline & 11 & 50.53 & 1.18 & 16.16 & 8.77 & 0.17 & 6.63 & 12.00 & 2.77 & 0.12 & 0.12 & 98.46 & 60.8 & 0.743 & 0.231 & 2.26 \\
\hline Mean (6) & 12 & 55.20 & 2.13 & 14.62 & 12.66 & 0.24 & 3.30 & 7.34 & 2.63 & 0.23 & 0.26 & 98.60 & 34.8 & 0.510 & 0.340 & 0.88 \\
\hline Mean (6) & 13 & 52.14 & 1.55 & 15.73 & 9.84 & 0.20 & 5.62 & 10.24 & 2.97 & 0.17 & 0.17 & 98.63 & 54.0 & 0.650 & 0.300 & 2.08 \\
\hline \multicolumn{17}{|c|}{$135-835 \mathrm{~A}-17 \mathrm{R}-3,137-140$} \\
\hline & 1 & 51.76 & 1.08 & 15.46 & 9.77 & 0.18 & 6.15 & 11.25 & 2.44 & 0.19 & 0.13 & 98.41 & 56.3 & 0.728 & 0.217 & 1.75 \\
\hline \multicolumn{17}{|l|}{$135-836 \mathrm{~A}-3 \mathrm{H}-2,83-85$} \\
\hline Mean (3) & 3 & 49.53 & 0.88 & 15.74 & 9.11 & 0.18 & 7.89 & 13.76 & 2.05 & 0.06 & 0.07 & 99.28 & 64.0 & 0.870 & 0.150 & 2.33 \\
\hline Mean (2) & 4 & 49.77 & 0.87 & 15.80 & 8.91 & 0.20 & 7.91 & 13.60 & 2.07 & 0.07 & 0.07 & 99.27 & 64.6 & 0.860 & 0.150 & 2.04 \\
\hline Mean (5) & 5 & 52.77 & 1.18 & 14.93 & 11.44 & 0.22 & 5.44 & 10.11 & 2.36 & 0.24 & 0.12 & 98.80 & 49.4 & 0.680 & 0.230 & 1.41 \\
\hline \multicolumn{17}{|l|}{$135-838 \mathrm{~A}-$} \\
\hline \multicolumn{17}{|l|}{$135-839 \mathrm{~B}-18 \mathrm{R}-1,6-8$} \\
\hline & 2 & 55.84 & 1.10 & 14.90 & 10.94 & 0.24 & 4.10 & 8.77 & 2.30 & 0.49 & 0.16 & 98.83 & 43.4 & 0.589 & 0.262 & 0.85 \\
\hline Mean (7) & 3 & 52.60 & 0.70 & 15.82 & 8.57 & 0.18 & 6.47 & 12.19 & 1.77 & 0.31 & 0.10 & 98.70 & 60.8 & 0.770 & 0.150 & 1.20 \\
\hline
\end{tabular}

Notes: $(\mathrm{N})$ suffix = analysis also given in Hergt and Nilsson (this volume). Numbers in parentheses indicate numbers of samples in mean. $\mathrm{Na}_{2} \mathrm{O} 8$ after $\mathrm{Klein}$ and $\mathrm{Langmuir}$ (1987).

the presence of sedimentary interbeds, and chemical data. Subunits were designated where nearly identical rocks were separated by thin layers of indurated or baked sediment. Thin sediment interbeds (centimeter to meter scale) separate some of the units; these help in paleontological dating of the presumed flows. The numerous sedimentary interbeds emphasize that, through the time span represented by our drill cores, episodic eruption occurred of lavas into a basin that was rapidly being infilled with volcaniclastic turbidites and hemipelagic sediments (see Rothwell et al., this volume, for a discussion). Igneous Units 1-9 range in age from early Pliocene (3.8 Ma) to late Miocene (5.5 Ma). Units 10-13 are older than 5.5 Ma. We have no data for the age of the beginning of volcanism at Site 834 , but it seems likely that it could have been $6 \mathrm{Ma}$ or older. Biostratigraphic data suggest that the basins were close to present depths when the lavas were erupted mainly as flows. Some may have been sills intruded close to the sediment seawater interface, but we did not recover any baked sediments at the upper surfaces to support this. Site 834 samples are basalts and differentiated basalts with basaltic andesite or Fe-Ti basalt compositions. All of the rocks are either low-K tholeiitic basalt or basaltic andesite and show a range in composition that probably reflects crystal fractionation. A summary of representative magma types from each unit is in Tables 2 and 3. The complete data set is in Appendixes A and B.

Samples collected at Site 834 comprise vitrophyres from chilled margins of flows or pillows and holocrystalline rocks from interior parts of flows or pillows. Nearly all the cored samples are obviously extrusive rocks in that they have fine grain size and glassy margins are common. The rocks are highly vesicular with up to $40-50$ modal $\%$ vesicles. This is one of the more significant textural features of the Site 834 samples and points to the importance of volatiles in their petrogenesis. High vesicularity is characteristic of the other drill sites as well as for most of the rocks dredged from the basin (e.g., Hawkins, 1976).

The rocks are formed mainly of plagioclase, olivine, and clinopyroxene; glass and vitrophyric rinds are common on chilled margins of flows and pillows. Nearly all samples have all three silicate phases as phenocrysts, microphenocrysts, or groundmass minerals. Chrome spinel and $\mathrm{Fe}-\mathrm{Ti}$ oxides are minor constituents, and $\mathrm{Fe}-$, or $\mathrm{Cu}-\mathrm{Fe}$, sulfides are present in trace amounts in most samples. Representative microprobe analyses are in Appendixes $\mathrm{C}-\mathrm{G}$ and displayed in Figure
2. Although the glass data are for visually unaltered material, all of the rock samples are altered to some extent and show some level of alteration. See Parson, Hawkins, Allan, et al. (1992) for a discussion of alteration at the drill sites discussed here.

Plagioclase is a major constituent of all of the samples. It occurs as phenocrysts, microphenocrysts, highly skeletal or swallowtail microphenocrysts in glass, and euhedral inclusions (chadacrysts) in large oikocrysts of clinopyroxene. Plagioclase phenocrysts form glomeroporphyritic aggregates, commonly with clinopyroxene, and rarely with olivine. The phenocrysts ( $>1 \mathrm{~mm}$ maximum dimension) typically are euhedral, with oscillatory and normally zoning, commonly having a sharply defined, narrow, sodic rim. Plagioclase composition at Site 834 ranges from $\mathrm{An}_{88.8}$ (phenocryst core composition in Subunit 10B) to $\mathrm{An}_{35.4}$ (phenocryst rim composition in Unit 5). Generally, the phenocryst rims, microphenocrysts, and groundmass compositions are the same in each rock sample studied. The K content of all samples analyzed is very low; typically they have an Or content of $0.2 \%$ or less. Plagioclase inclusions in clinopyroxene oikocrysts of Unit 5 show progressive compositional change from $\mathrm{An}_{69}$ to $\mathrm{An}_{48}$ from the interior to the exterior of the host clinopyroxene. Considering all of the samples analyzed, the $\mathrm{FeO}^{*}$ content ranges from $0.4 \%$ to $1.7 \%$, and a strong positive correlation exists between $\mathrm{FeO}^{*}$ and $\mathrm{Na} /(\mathrm{Na}+\mathrm{Ca})$. No apparent relationship is present between plagioclase composition and sample depth, nor does a relationship exist between bulk-rock composition and depth.

Olivine forms euhedral phenocrysts and microphenocrysts as well as highly skeletal, quench-textured crystals. With the exception of Units $6,10,12$, and 13 , the olivine shows a narrow range in composition from $\mathrm{Fo}_{80}$ to $\mathrm{Fo}_{88}$; most of the units have olivine more magnesian than $\mathrm{Fo}_{84}$. Unit 7 has the most magnesian olivine with $\mathrm{Fo}_{88}$ cores and $\mathrm{Fo}_{86}$ rims. Throughout the sample set, grain rims typically are 1-2 mol\% less magnesian than grain cores and generally overlap with microphenocryst compositions (Fig. 2D). Many of the olivine grain cores may be xenocrysts as evidenced by comparison of $\mathrm{Fe} / \mathrm{Mg}$ of grain cores, rims, and enclosing glass, which suggests that many grain cores are not in equilibrium with the enclosing glass whereas the rims are in equilibrium. The ratio $(\mathrm{Fe} / \mathrm{Mg})_{\mathrm{OL}} /(\mathrm{Fe} / \mathrm{Mg})_{\text {glass }}=0.27$ as calculated from the data, and assuming $\mathrm{Fe}^{3+} / \mathrm{Fe}^{2+}=0.15$ for the glass. This 
Table 3. Representative analyses of rocks, XRF data.

\begin{tabular}{|c|c|c|c|c|c|c|c|c|c|c|c|c|c|c|c|c|}
\hline $\begin{array}{l}\text { Core, section, } \\
\text { interval }(\mathrm{cm})\end{array}$ & Unit & $\begin{array}{l}\text { Depth } \\
\text { (mbsf) }\end{array}$ & $\mathrm{SiO}_{2}$ & $\mathrm{TiO}_{2}$ & $\mathrm{Al}_{2} \mathrm{O}_{3}$ & $\mathrm{FeO}^{\circ}$ & $\mathrm{Fe}_{2} \mathrm{O}_{3}$ & $3 \mathrm{FeO}$ & $\mathrm{MnO}$ & $\mathrm{MgO}$ & $\mathrm{CaO}$ & $\mathrm{Na}_{2} \mathrm{O}$ & $\mathrm{K}_{2} \mathrm{O}$ & $\mathrm{P}_{2} \mathrm{O}_{5}$ & Sum & Mg\# \\
\hline \multicolumn{17}{|l|}{$135-834 \mathrm{~A}-$} \\
\hline $12 \mathrm{X}-\mathrm{CC}, 20-22$ & 1 & 106.03 & 47.78 & 1.28 & 21.83 & 8.00 & 1.16 & 6.96 & 0.14 & 6.24 & 11.71 & 3.38 & 0.21 & 0.19 & 100.75 & 61.5 \\
\hline $12 \mathrm{X}-\mathrm{CC}, 13-15^{\circ}$ & $i$ & 105.96 & 49.78 & 1.40 & 17.51 & 8.47 & 1.22 & 7.37 & 0.15 & 5.06 & 12.71 & 3.08 & 0.26 & 0.15 & 99.48 & 55.0 \\
\hline $8 \mathrm{R}-1,105-109^{\circ}$ & 2 & 127.15 & 50.70 & 1.33 & 16.24 & 9.11 & 1.32 & 7.92 & 0.13 & 7.19 & 11.04 & 3.09 & 0.18 & 0.13 & 100.13 & 61.8 \\
\hline $14 X-1,4-6$ & 2 & 117.04 & 50.57 & 1.49 & 16.49 & 9.74 & 1.41 & 8.47 & 0.18 & 5.77 & 11.36 & 3.10 & 0.36 & 0.18 & 100.30 & 54.8 \\
\hline $16 \mathrm{X}-\mathrm{CC}, 30-33^{\circ}$ & 4 & 134.13 & 50.81 & 1.13 & 17.55 & 8.13 & 1.18 & 7.07 & 0.13 & 6.34 & 12.59 & 2.69 & 0.11 & 0.11 & 100.47 & 61.5 \\
\hline \multicolumn{17}{|l|}{$135-834 \mathrm{~B}-$} \\
\hline $13 \mathrm{R}-1,130-131$ & $\begin{array}{l}5 \\
5\end{array}$ & $\begin{array}{l}158.60 \\
162.30\end{array}$ & $\begin{array}{l}50.00 \\
49.27\end{array}$ & $\begin{array}{l}1.05 \\
1.09\end{array}$ & $\begin{array}{l}17.20 \\
15.91\end{array}$ & $\begin{array}{l}8.01 \\
7.96\end{array}$ & $\begin{array}{l}1.16 \\
1.16\end{array}$ & $\begin{array}{l}6.97 \\
6.92\end{array}$ & $\begin{array}{l}0.13 \\
0.14\end{array}$ & $\begin{array}{l}8.99 \\
7.99\end{array}$ & $\begin{array}{l}11.54 \\
11.19\end{array}$ & $\begin{array}{l}2.57 \\
3.90\end{array}$ & $\begin{array}{l}0.12 \\
0.18\end{array}$ & $\begin{array}{l}0.10 \\
0.21\end{array}$ & $\begin{array}{r}100.57 \\
97.84\end{array}$ & $\begin{array}{l}69.7 \\
67.3\end{array}$ \\
\hline $18 \mathrm{R}-1,14-21$ & 6 & 204.14 & 49.75 & 1.10 & 16.78 & 8.58 & 1.24 & 7.46 & 0.16 & 7.20 & 12.32 & 3.46 & 0.09 & 0.21 & 99.64 & 63.2 \\
\hline $15 R-2,56-62$ & 6 & 177.36 & 50.79 & 1.74 & 17.24 & 9.76 & 1.41 & 8.49 & 0.19 & 5.66 & 10.57 & 3.47 & 0.32 & 0.26 & 99.98 & 54.3 \\
\hline $31 \mathrm{R}-3,19-25^{\circ}$ & 7 & 269.68 & 49.51 & 1.21 & 17.57 & 7.70 & 1.11 & 6.70 & 0.13 & 7.88 & 11.82 & 2.64 & 0.06 & 0.10 & 99.49 & 67.7 \\
\hline $29 \mathrm{R}-1,7-12$ & 7 & 257.37 & 46.68 & 1.23 & 21.61 & 7.80 & 1.13 & 6.78 & 0.14 & 5.49 & 12.41 & 3.91 & 0.12 & 0.20 & 99.59 & 59.1 \\
\hline $36 \mathrm{R}-1,65-68^{\circ}$ & 8 & 301.15 & 50.32 & 1.35 & 16.33 & 8.24 & 1.19 & 7.17 & 0.14 & 7.33 & 11.83 & 2.58 & 0.19 & 0.12 & 99.33 & 64.6 \\
\hline $35 R-1,115-125$ & 8 & 291.95 & 50.02 & 1.05 & 17.61 & 8.31 & 1.20 & 7.23 & 0.15 & 6.79 & 11.73 & 2.86 & 0.16 & 0.17 & 98.84 & 62.6 \\
\hline $37 \mathrm{R}-1,47-50^{\circ}$ & $9 \mathrm{~B}$ & 310.67 & 51.21 & 1.57 & 16.66 & 9.13 & 1.32 & 7.94 & 0.17 & 6.54 & 11.45 & 3.01 & 0.31 & 0.16 & 101.21 & 59.5 \\
\hline $39 \mathrm{R}-1,16-21$ & $10 \mathrm{~A}$ & 324.96 & 50.54 & 1.39 & 17.21 & 8.75 & 1.27 & 7.61 & 0.16 & 5.81 & 11.48 & 4.27 & 0.29 & 0.25 & 100.14 & 57.6 \\
\hline $42 \mathrm{R}-1,0-5$ & $10 \mathrm{~A}$ & 339.10 & 48.91 & 1.99 & 17.86 & 12.12 & 1.76 & 10.54 & 0.21 & 3.67 & 8.04 & 4.37 & 0.66 & 0.22 & 98.05 & 38.3 \\
\hline $46 \mathrm{R}-1,37-40$ & $10 \mathrm{~B}$ & 358.87 & 49.33 & 1.13 & 16.79 & 8.55 & 1.24 & 7.43 & 0.16 & 7.41 & 12.36 & 3.23 & 0.11 & 0.20 & 99.26 & 64.0 \\
\hline $47 \mathrm{R}-1,130-135$ & 12 & 364.80 & 52.98 & 1.71 & 16.55 & 9.79 & 1.42 & 8.51 & 0.18 & 4.07 & 8.12 & 4.39 & 0.63 & 0.26 & 98.69 & 46.0 \\
\hline $56 \mathrm{R}-1,7-15^{\circ}$ & 12 & 406.97 & 52.20 & 2.11 & 15.71 & 12.41 & 1.80 & 10.79 & 0.20 & 3.40 & 8.58 & 3.87 & 0.73 & 0.21 & 100.78 & 36.0 \\
\hline $59 \mathrm{R}-2,52-55$ & 13 & 432.95 & 45.54 & 1.04 & 25.53 & 7.71 & 1.12 & 6.70 & 0.14 & 6.77 & 11.05 & 2.55 & 0.16 & 0.17 & 100.67 & 64.3 \\
\hline $58 \mathrm{R}-1,92-99$ & 13 & 426.92 & 49.37 & 1.52 & 16.80 & 10.74 & 1.56 & 9.34 & 0.19 & 5.23 & 10.23 & 3.83 & 0.46 & 0.20 & 98.57 & 50.0 \\
\hline \multicolumn{17}{|l|}{ 135-835B- } \\
\hline $7 \mathrm{R}-2,75$ & 1 & 179.95 & 51.22 & 0.80 & 15.72 & 8.24 & 1.19 & 7.17 & 0.12 & 7.71 & 12.27 & 2.17 & 0.17 & 0.19 & ND & 65.7 \\
\hline $6 \mathrm{R}-1,114-117^{\circ}$ & 1 & 174.84 & 49.80 & 1.23 & 16.17 & 9.66 & 1.40 & 8.40 & 0.19 & 6.70 & 12.33 & 2.19 & 0.21 & 0.12 & 99.66 & 58.7 \\
\hline \multicolumn{17}{|l|}{$135-836 \mathrm{~A}=$} \\
\hline $3 \mathrm{H}-3,33-43$ & 1 & 14.50 & 54.89 & 1.27 & 14.24 & 11.70 & 1.70 & 10.17 & 0.18 & 3.87 & 8.60 & 3.02 & 0.28 & 0.20 & 98.26 & 40.4 \\
\hline $3 \mathrm{H}-4,88-100$ & 2 & 18.00 & 55.77 & 1.12 & 14.07 & 11.04 & 1.60 & 9.60 & 0.23 & 3.69 & 8.24 & 3.12 & 0.31 & 0.20 & 97.80 & 40.7 \\
\hline $7,54-55$ & 3 & 20.12 & 47.13 & 0.69 & 19.18 & 8.08 & 1.17 & 7.03 & 0.16 & 8.88 & 13.03 & 1.90 & 0.00 & 0.14 & 99.20 & 69.3 \\
\hline $9 X-2,29-34$ & 4 & 36.95 & 49.07 & 0.72 & 16.39 & 8.13 & 1.18 & 7.07 & 0.13 & 9.38 & 13.43 & 2.19 & 0.01 & 0.13 & 99.57 & 70.3 \\
\hline $8 X-1,29-34$ & 4 & 31.49 & 50.22 & 1.05 & 18.72 & 10.84 & 1.57 & 9.43 & 0.19 & 5.66 & 10.67 & 2.49 & 0.23 & 0.16 & 100.23 & 51.7 \\
\hline \multicolumn{17}{|l|}{ 135-836B- } \\
\hline $3 \mathrm{R}-1,68$ & $4 \mathrm{~A}$ & 3. & 48.38 & 0.7 & 16 & 8.3 & 1.2 & 7.2 & 0. & 7.5 & 14 & 1.5 & 0.11 & 0.06 & 99.72 & 66.2 \\
\hline $5 R-1,67-72$ & $4 B$ & 34.67 & 49.08 & 0.6 & 17.01 & 8.1 & 1.18 & 7.0 & 0.14 & 9.5 & 13.79 & 2.35 & 0.01 & 0.13 & 100.82 & 70.5 \\
\hline $7 R-2,56-62$ & 5 & 45.76 & 48.08 & 0.72 & 16.21 & 8.13 & 1.18 & 7.07 & 0.14 & 9.07 & 13.78 & 2.33 & 0.01 & 0.14 & 98.59 & 69.6 \\
\hline 8R-1, & 5 & 53.41 & 52.13 & 1.08 & 16.42 & 11.04 & 1.60 & 9.60 & 0.19 & 5.89 & 11.05 & 2.34 & 0.22 & 0.16 & 100.51 & 52.2 \\
\hline \multicolumn{17}{|l|}{$135-837 \mathrm{~B}-$} \\
\hline $3 R-1,34-39$ & 1 & 80.54 & 55.95 & 1.35 & 15.39 & 11.95 & 1.73 & 10.39 & 0.20 & 3.57 & 8.24 & 2.84 & 0.71 & 0.22 & 100.43 & 38.0 \\
\hline \multicolumn{17}{|l|}{ 135-839B- } \\
\hline $13 \mathrm{R}-2,72-77^{*}$ & I & 220.42 & 52.7 & 0. & 15 & 9.05 & 1.31 & 7.87 & 0.1 & 9.0 & 11. & 1.36 & 0.3 & 0.07 & 101.00 & 67.2 \\
\hline $13 R-2,106-110$ & 1 & 220.76 & 52.51 & 0.62 & 15.13 & 8.76 & 1.27 & 7.62 & 0.15 & 8.05 & 11.62 & 1.57 & 0.28 & 0.18 & 98.87 & $\begin{array}{l}65.3 \\
50.2\end{array}$ \\
\hline $18 \mathrm{R}-1,48-52$ & 2 & 266.88 & 52.70 & 0.82 & 18.38 & 9.51 & 1.38 & 8.27 & 0.16 & $\begin{array}{r}4.67 \\
19.26\end{array}$ & $\begin{array}{l}9.98 \\
8.97\end{array}$ & 2.05 & 0.53 & 0.19 & 98.99 & $\begin{array}{l}50.2 \\
82.0\end{array}$ \\
\hline $25 \mathrm{R}-1,17-22$. & $\begin{array}{l}3 \\
3\end{array}$ & $\begin{array}{l}334.17 \\
276.50\end{array}$ & $\begin{array}{l}46.77 \\
50.63\end{array}$ & $\begin{array}{l}0.46 \\
0.58\end{array}$ & 12.17 & 8.64 & 1.26 & 7.51 & 0.16 & $\begin{array}{l}19.26 \\
14.15\end{array}$ & $\begin{array}{r}8.97 \\
10.98\end{array}$ & 1.19 & $\begin{array}{l}0.25 \\
0.32\end{array}$ & $\begin{array}{l}0.14 \\
0.07\end{array}$ & $\begin{array}{r}98.00 \\
10085\end{array}$ & $\begin{array}{l}82.0 \\
76.4\end{array}$ \\
\hline $\begin{array}{l}19 \mathrm{R}-1,50-56^{\circ} \\
26 \mathrm{R}-1,23-29^{\circ}\end{array}$ & $\begin{array}{l}3 \\
4\end{array}$ & $\begin{array}{l}276.50 \\
343.83\end{array}$ & $\begin{array}{l}50.63 \\
51.64\end{array}$ & $\begin{array}{l}0.5 \\
0.5\end{array}$ & $\begin{array}{l}12.75 \\
14.33\end{array}$ & $\begin{array}{l}8.94 \\
8.48\end{array}$ & $\begin{array}{l}1.30 \\
1.23\end{array}$ & $\begin{array}{l}7.77 \\
7.37\end{array}$ & $\begin{array}{l}0.16 \\
0.17\end{array}$ & $\begin{array}{r}14.15 \\
9.72\end{array}$ & $\begin{array}{l}10.98 \\
13.64\end{array}$ & $\begin{array}{l}1.28 \\
1.15\end{array}$ & $\begin{array}{l}0.32 \\
0.22\end{array}$ & $\begin{array}{l}0.07 \\
0.04\end{array}$ & $\begin{array}{l}100.85 \\
100.92\end{array}$ & $\begin{array}{l}70.4 \\
70.1\end{array}$ \\
\hline $27 \mathrm{R}-1,15-19^{*}$ & 5 & 353.45 & 54.15 & 0.85 & 16.55 & 9.95 & 1.44 & 8.65 & 0.19 & 4.36 & 9.85 & 1.99 & 0.65 & 0.13 & 99.78 & 47.30 \\
\hline $27 \mathrm{R}-1,21-24^{*}$ & 6 & 353.51 & 50.45 & 0.58 & 12.75 & 8.91 & 1.29 & 7.75 & 0.17 & 13.71 & 11.00 & 1.71 & 0.29 & 0.07 & 100.63 & 75.90 \\
\hline $27 \mathrm{R}-1,38-42^{\circ}$ & 7 & 353.68 & 55.02 & 0.87 & 16.46 & 10.11 & 1.47 & 8.79 & 0.20 & 4.35 & 9.80 & 1.96 & 0.78 & 0.13 & 100.80 & 46.90 \\
\hline $41 \mathrm{R}-1,5-10^{\circ}$ & 9 & 487.55 & 53.41 & 0.81 & 16.12 & 10.24 & 1.49 & 8.90 & 0.19 & 5.76 & 10.80 & 1.72 & 0.39 & 0.08 & 100.64 & 53.60 \\
\hline $36 \mathrm{R}-1,21-24$ & 9 & 439.81 & 53.02 & 0.76 & 17.92 & 9.11 & 1.32 & 7.92 & 0.16 & 4.81 & 10.38 & 1.85 & 0.47 & 0.18 & 98.65 & 52.00 \\
\hline
\end{tabular}

Notes: An asterisk $(*)=$ shipboard analysis (Parson, Hawkins, Allan, et al., 1992). ND = not determined.

suggests that the $\mathrm{fO}_{2}$ for these magmas was higher than for typical MORB (see also Nilsson, this volume).

Clinopyroxene forms small phenocrysts, microphenocrysts, glomeroporphyritic aggregates with plagioclase, and the large oikocrysts that distinguish Unit 5. It also forms sheaflike bundles of acicular fine-textured grains that are common in the groundmass of many aphyric to sparsely phyric samples. Data for 83 grains lie mainly in the field for augite with some in the endiopside field of the pyroxene quadrilateral (Fig. 2A). The composition ranges from $\mathrm{En}_{54} \mathrm{Wo}_{37}$ to $\mathrm{En}_{35} \mathrm{Wo}_{40}$. Individual samples have a small compositional range, but the range for each unit may be considerable. Of the nonquadrilateral components, $\mathrm{Al}_{2} \mathrm{O}_{3}$ and $\mathrm{TiO}_{2}$ show the greatest range, $1.35 \%-6.25 \%$ and $0.35 \%-2.32 \%$, respectively. Both $\mathrm{Na}$ and $\mathrm{Ti}$ display a strong negative correlation with $\mathrm{En}$. Al shows a fair negative correlation with En, but much scatter is present. Collectively, the nonquadrilateral components show a broad negative correlation with En, but considerable scatter is imposed by the range in $\mathrm{Al}$.

Chrome spinel is present in Units 1, 3, 5, 7, and 13. Site 834 spinels, as well as those at other sites, approximate the formula $\left(\mathrm{Mg}, \mathrm{Fe}^{2+}\right)(\mathrm{Al}$,
$\left.\mathrm{Cr}, \mathrm{Fe}^{3+}\right)_{2} \mathrm{O}_{4}$ with minor $\mathrm{TiO}_{2}(0.17 \%-1.62 \%), \mathrm{V}_{2} \mathrm{O}_{3}(0.02 \%-0.30 \%)$, $\mathrm{NiO}(<0.01 \%-0.27 \%), \mathrm{MnO}(<0.01 \%-0.34 \%), \mathrm{ZnO}(<0.01 \%-0.20 \%)$, and low $\mathrm{Fe}_{2} \mathrm{O}_{3}(4.5 \%-14.2 \%$, generally $<8 \%)$. Representative data are given in Appendix F; see Allan (this volume) for a more extensive discussion. Spinel data given here are from Units 1 and 7, the youngest unit and the least evolved unit, respectively. $\mathrm{The} \mathrm{Cr} /(\mathrm{Cr}+\mathrm{Al})$ is low, ranging from 0.38 to 0.48 , and resembles MORB values and data for the Lau Basin spreading centers (Dick and Bullen, 1984; Hawkins and Melchior, 1985; Allan et al., 1988). As discussed subsequently, they differ markedly from spinels at Site 839 (arc-like magmas) but are similar to those at Site 836 (MORB-like magmas). The spinels typically are euhedral and most commonly are found as separate crystals in the groundmass, as inclusions in plagioclase, or attached to plagioclase. More rarely, they occur as inclusions in olivine or adjacent to it. Most of the spinel grains are between 10 and $100 \mu \mathrm{m}$ in size, although some spinels in Unit 7 are as large as $200 \mu \mathrm{m}$. Compositional zoning is minimal (see Allan, this volume, for examples of spinel core-rim pairs).

The Ti-rich magnetite generally is confined to the groundmass, where it occurs as equant to skeletal crystals generally $<0.1 \mathrm{~mm}$ in 
Table 3 (continued).

\begin{tabular}{|c|c|c|c|c|c|c|c|c|c|c|c|c|c|c|}
\hline $\begin{array}{l}\text { Core, section, } \\
\text { interval }(\mathrm{cm})\end{array}$ & $\mathrm{CaO} / \mathrm{Al}_{2} \mathrm{O}_{3}$ & $\mathrm{Ti} / \mathrm{Zr}$ & $\mathrm{Zr}$ & $\mathrm{Y}$ & $\mathrm{Nb}$ & $\mathrm{Sr}$ & $\mathrm{Rb}$ & $\mathrm{Ba}$ & $\mathrm{Ni}$ & $\mathrm{Cr}$ & V & $\mathrm{Ce}$ & $\mathrm{Y} / \mathrm{Zr}$ & $\mathrm{Zr} / \mathrm{Nb}$ \\
\hline \multicolumn{15}{|l|}{$135-834 \mathrm{~A}-$} \\
\hline $12 \mathrm{X}-\mathrm{CC}, 20-22$ & 0.54 & 70.4 & 109 & 30 & 4 & 229 & 4 & 26 & 58 & ND & 231 & ND & 0.275 & 27.3 \\
\hline $12 \mathrm{X}-\mathrm{CC}, 13-15^{*}$ & 0.73 & 69.9 & 120 & 28 & 2 & 245 & 5 & 41 & 53 & 267 & ND & 22 & 0.233 & 60.0 \\
\hline $8 \mathrm{R}-1,105-109^{\circ}$ & 0.68 & 78.2 & 102 & 27 & 1 & 187 & 1 & 49 & 40 & 41 & ND & 13 & 0.265 & 102.0 \\
\hline $14 X-1,4-6^{\circ}$ & 0.69 & 79.1 & 113 & 31 & 2 & 210 & 5 & 64 & 27 & 6 & ND & 14 & 0.274 & 56.5 \\
\hline $16 \mathrm{X}-\mathrm{CC}, 30-33^{*}$ & 0.72 & 76.1 & 89 & 24 & 2 & 186 & 0 & 35 & 105 & 234 & ND & 15 & 0.270 & 44.5 \\
\hline \multirow{2}{*}{\multicolumn{15}{|c|}{$\begin{array}{l}135-834 \mathrm{~B}- \\
12 \mathrm{R}-3,66-71^{\circ}\end{array}$}} \\
\hline & 0.67 & 80.7 & 78 & 21 & 1 & 170 & 1 & 49 & 91 & 191 & ND & 7 & 0.269 & 78.0 \\
\hline $13 \mathrm{R}-1,130-131$ & 0.70 & 75.1 & 87 & 29 & 2 & 176 & 1 & ND & 96 & ND & ND & ND & 0.333 & 43.5 \\
\hline $18 \mathrm{R}-1,14-21$ & 0.73 & 89.1 & 74 & 29 & 4 & 161 & 2 & 32 & 55 & ND & 241 & ND & 0.392 & 18.5 \\
\hline $15 R-2,56-62$ & 0.61 & 71.0 & 147 & 43 & 4 & 179 & 3 & 36 & 38 & ND & 281 & ND & 0.293 & 36.8 \\
\hline $31 \mathrm{R}-3,19-25^{*}$ & 0.67 & 75.6 & 96 & 25 & 2 & 167 & 1 & 22 & 95 & 313 & ND & 11 & 0.260 & 48.0 \\
\hline $29 \mathrm{R}-1,7-12$ & 0.57 & 72.3 & 102 & 29 & 3 & 176 & 3 & 22 & 102 & ND & 227 & ND & 0.284 & 34.0 \\
\hline $36 \mathrm{R}-1,65-68^{\circ}$ & 0.72 & 99.9 & 81 & 25 & 1 & 165 & 3 & 36 & 52 & 139 & ND & 13 & 0.309 & 81.0 \\
\hline $35 \mathrm{R}-1,115-125$ & 0.67 & 76.8 & 82 & 26 & 2 & 154 & 2 & 37 & 56 & ND & 224 & ND & 0.317 & 41.0 \\
\hline $37 \mathrm{R}-1,47-50^{\circ}$ & 0.69 & 79.8 & 118 & 35 & 2 & 142 & 5 & 40 & 115 & 196 & ND & 16 & 0.297 & 59.0 \\
\hline $39 \mathrm{R}-1,16-21$ & 0.67 & 70.0 & 119 & 37 & 2 & 170 & 6 & 34 & 70 & ND & 255 & ND & 0.311 & 59.5 \\
\hline $42 \mathrm{R}-1,0-5$ & 0.45 & 86.4 & 138 & 43 & 5 & 186 & 7 & 42 & 12 & ND & 367 & ND & 0.312 & 27.6 \\
\hline $46 \mathrm{R}-1,37-40$ & 0.74 & 96.8 & 70 & 22 & 3 & 155 & 2 & 30 & 74 & ND & 212 & ND & 0.314 & 23.3 \\
\hline $47 R-1,130-135$ & 0.49 & 64.1 & 160 & 50 & 5 & 148 & 13 & 48 & 21 & ND & 278 & ND & 0.313 & 32.0 \\
\hline $56 \mathrm{R}-1,7-15^{\circ}$ & 0.55 & 86.6 & 146 & 40 & 1 & 195 & 13 & 60 & 12 & 0 & ND & 15 & 0.274 & 146.0 \\
\hline $59 \mathrm{R}-2,52-55$ & 0.43 & 77.9 & 80 & 26 & 4 & 148 & 2 & 38 & 65 & ND & 221 & ND & 0.325 & 20.0 \\
\hline $58 \mathrm{R}-1,92-99$ & 0.61 & 86.8 & 105 & 35 & 3 & 192 & 11 & 38 & 32 & ND & 324 & ND & 0.333 & 35.0 \\
\hline \multicolumn{15}{|l|}{ 135-835B- } \\
\hline $7 \mathrm{R}-2,75-84$ & 0.78 & 94.0 & 51 & 25 & 2 & 129 & 2 & ND & 70 & ND & ND & ND & 0.490 & 25.5 \\
\hline $6 \mathrm{R}-1,114-117^{*}$ & 0.76 & 150.5 & 49 & 25 & 1 & 135 & 5 & 64 & 60 & 127 & ND & ND & 0.510 & 49.0 \\
\hline \multicolumn{15}{|l|}{$135-836 \mathrm{~A}-$} \\
\hline $3 \mathrm{H}-3,33-43$ & 0.60 & 96.4 & 79 & 32 & 2 & 142 & 5 & ND & 13 & ND & ND & ND & 0.405 & 39.5 \\
\hline $3 \mathrm{H}-4,88-100$ & 0.59 & 83.9 & 80 & 35 & 3 & 141 & 3 & ND & 15 & ND & ND & ND & 0.438 & 26.7 \\
\hline $3 \mathrm{H}-7,54-55$ & 0.68 & 88.0 & 47 & 19 & 2 & 140 & 0.1 & 17 & 111 & ND & 216 & ND & 0.404 & 23.5 \\
\hline $9 X-2,29-34$ & 0.82 & 89.9 & 48 & 18 & 2 & 153 & 1 & 25 & 104 & ND & 181 & ND & 0.375 & 24.0 \\
\hline $8 X-1,29-34$ & 0.57 & 106.7 & 59 & 28 & 2 & 146 & 2 & 33 & 31 & ND & 368 & ND & 0.475 & 29.5 \\
\hline \multicolumn{15}{|l|}{$135-836 \mathrm{~B}-$} \\
\hline $3 \mathrm{R}-1,68-70^{\circ}$ & 0.87 & 80.3 & 56 & 18 & 1 & 356 & 7 & 11 & 103 & 342 & ND & 10 & 0.321 & 56.0 \\
\hline $5 R-1,67-72$ & 0.81 & 90.6 & 30 & 18 & 2 & 155 & 1 & 20 & 112 & ND & 187 & ND & 0.419 & 21.5 \\
\hline $7 R-2,56-62$ & 0.85 & 98.1 & 44 & 20 & 2 & 319 & 2 & 19 & 120 & ND & 157 & ND & 0.455 & 22.0 \\
\hline $8 \mathrm{R}-1,11-17$ & 0.67 & 109.7 & 59 & 26 & 2 & 146 & 5 & 30 & 28 & ND & 350 & ND & 0.441 & 29.5 \\
\hline \multicolumn{15}{|l|}{ 135-837B- } \\
\hline 3R-1, 34-39 & 0.54 & 97.5 & 83 & 37 & 3 & 167 & 9 & ND & 6 & ND & ND & ND & 0.446 & 27.7 \\
\hline \multicolumn{15}{|l|}{ 135-839B- } \\
\hline $13 R-2,72-77^{\circ}$ & 0.77 & 128.2 & 29 & 14 & 1 & 143 & 13 & 59 & 130 & 644 & ND & 7 & 0.483 & 29.0 \\
\hline $13 \mathrm{R}-2,106-110$ & 0.77 & 97.8 & 38 & 20 & 1 & 150 & 7 & ND & 114 & ND & ND & ND & 0.526 & 38.0 \\
\hline $18 \mathrm{R}-1,48-52$ & 0.54 & 96.4 & 51 & 24 & 2 & 190 & 8 & ND & 16 & ND & ND & ND & 0.471 & 25.5 \\
\hline $25 \mathrm{R}-1,17-22$ & 0.74 & 72.6 & 38 & 15 & 1 & 120 & 4 & ND & 384 & ND & ND & ND & 0.395 & 38.0 \\
\hline $19 \mathrm{R}-1,50-56^{\circ}$ & 0.86 & 105.4 & 33 & 14 & 1 & 137 & 4 & 62 & 283 & 1229 & ND & 12 & 0.424 & 33.0 \\
\hline 26R-1, 23-29". & 0.95 & 126.6 & 27 & 15 & 1 & 117 & 3 & 44 & 92 & 445 & ND & 6 & 0.556 & 27.0 \\
\hline $27 \mathrm{R}-1,15-19^{\circ}$ & 0.60 & 98.0 & 52 & 20 & $i$ & 217 & 9 & 114 & 12 & 3 & ND & 9 & 0.385 & 52.0 \\
\hline $27 \mathrm{R}-1,21-24^{\circ}$ & 0.86 & 105.4 & 33 & 14 & 1 & 140 & 5 & 58 & 258 & 1391 & ND & 2 & 0.424 & 33.0 \\
\hline $27 \mathrm{R}-1,38-42^{*}$ & 0.60 & 100.3 & 52 & 21 & $i$ & 215 & 12 & 127 & 11 & 4 & ND & 15 & 0.404 & 52.0 \\
\hline $41 R-1,5-10^{2}$ & 0.67 & 107.9 & 45 & 20 & 1 & 185 & 5 & 72 & 20 & 10 & ND & 10 & 0.444 & 45.0 \\
\hline $36 \mathrm{R}-1,21-24$ & 0.58 & 94.9 & 48 & 22 & 2 & 183 & 7 & ND & 22 & ND & ND & ND & 0.458 & 24.0 \\
\hline
\end{tabular}

size. Much larger (e.g., as large as $0.3 \mathrm{~mm}$ ) equant or skeletal grains are present in more slowly cooled lavas, as in Units 5 and 7. Microprobe analyses of some representative grains are in Appendix G.

Several units have distinctive textures or other features. Relative to the other 12 units, Unit 5 has coarser grain size, lacks internal chill margins, and appears to be a single 27 -m-thick cooling unit that probably was a flow. Unit 5 is also distinctive in having a groundmass formed of a network of large clinopyroxene oikocrysts that poikilitically enclose smaller plagioclase crystals. Miarolitic cavities, partly filled with alteration products or secondary minerals, also are common. Unit 7 is the only highly phyric unit; it has $10-25$ modal\% phenocrysts (plagioclase $\gg$ clinopyroxene $\gg$ olivine. Unit 7 also is distinctive in being essentially nonvesicular. Unit 8 , in contrast, has abundant small vesicles ( $20-45$ modal $\%)$ in a glass-rich rock that has only a trace of glomerocrysts of plagioclase and clinopyroxene and minor olivine. The other units are aphyric to sparsely phyric rocks of which nearly all have all three silicate phases forming phenocrysts as well as being constituents of the groundmass. The deepest unit sampled (Unit 13) has all three phases as phenocrysts but olivine is subordinate and is the most $\mathrm{Fe}$-rich analyzed $\left(\mathrm{Fo}_{6}-\mathrm{Fo}_{68}\right)$. With the exception of Unit 7, all of the units are vesicular with vesicles abundances varying from about $10 \%$ (e.g., Unit 12 ) to as much as $50 \%$ (e.g., Unit 6).

\section{Site $\mathbf{8 3 5}$}

\section{Introduction}

Site 835 (Fig. 1 and Table 1) is in the west central Lau Basin approximately $200 \mathrm{~km}$ east of the foot of the Lau Ridge (remnant arc) and about $80 \mathrm{~km}$ west of the CLSC. Paleontologic and magnetostratigraphic dating gave a probable minimum age for igneous basement of about 3.2 Ma (late Pliocene); this confirmed previous estimates of about 3 Ma determined from magnetic anomaly data. The drill site is in a fault-bounded basin, or graben, more than $2900 \mathrm{~m}$ deep. This basin is on the eastern flank of a broad, north-trending bathymetric high, centered on $18^{\circ} 35^{\prime} \mathrm{S}, 177^{\circ} 25^{\prime} \mathrm{W}$, which rises to a depth of about $1650 \mathrm{~m}$. This shoal area is but one of many upstanding blocks that, together with intervening broad basins and troughs, characterize the 
Table 4. INAA analyses of Leg 135 bulk rocks.

\begin{tabular}{|c|c|c|c|c|c|c|c|c|c|c|c|c|c|c|}
\hline Hole: & $834 \mathrm{~A}$ & 834B & $834 \mathrm{~A}$ & $834 \mathrm{~A}$ & $834 \mathrm{~A}$ & $834 B$ & $834 \mathrm{~B}$ & $834 B$ & $834 \mathrm{~B}$ & 834B & 834B & 834B & $834 B$ & 834B \\
\hline Core, section: & $14 X-1$ & $8 \mathrm{R}-1$ & $15 X-1$ & $16 \mathrm{X}-\mathrm{CC}$ & $10 \mathrm{R}-1$ & $12 \mathrm{R}-1$ & $12 R-3$ & $13 R-1$ & 18R-1 & 26R-1 & 28R-1 & $30 \mathrm{R}-3$ & $33 \mathrm{R}-2$ & $36 \mathrm{R}-1$ \\
\hline INAA interval: & 0 & 77 & 26 & 11 & 26 & 31 & 61 & 130 & 50 & 53 & 35 & 94 & 105 & 25 \\
\hline Unit: & $2 \mathrm{~A}$ & 2 & 2B & 3 & 4 & 5 & 5 & 5 & 6 & 7 & 7 & 7 & 7 & 8 \\
\hline $\mathrm{Na}$ & 2.50 & 2.17 & 2.43 & 2.05 & 2.20 & 2.07 & 1.86 & 2.00 & 2.40 & 1.99 & 2.10 & 1.92 & 1.97 & 1.95 \\
\hline $\mathrm{Fe}$ & 8.13 & 6.65 & 6.88 & 5.88 & 6.11 & 6.02 & 5.81 & 6.02 & 6.44 & 5.64 & 5.69 & 5.93 & 5.89 & 5.82 \\
\hline Sc & 39.5 & 39.1 & 37.9 & 37.2 & 38.4 & 34.3 & 36.0 & 37.1 & 31.7 & 31.1 & 31.4 & 32.9 & 33.6 & 34.4 \\
\hline $\mathrm{Cr}$ & 20 & 62 & 43 & 248 & 246 & 202 & 259 & 238 & 183 & 294 & 310 & 320 & 321 & 188 \\
\hline Co & 40.3 & 36.9 & 37.2 & 29.9 & 40.6 & 37.3 & 37.0 & 38.0 & 33.6 & 35.4 & 36.3 & 36.8 & 36.8 & 34.7 \\
\hline $\mathrm{Zn}$ & 108 & 91 & 102 & 82 & 83 & 88 & 77 & 88 & 88 & 77 & 74 & 80 & 83 & 89 \\
\hline $\mathrm{Sr}$ & 282 & 142 & 204 & 285 & 219 & 163 & 164 & 150 & 138 & 167 & 168 & $<119$ & 167 & 148 \\
\hline $\mathrm{La}$ & 4.22 & 3.27 & 3.63 & 2.80 & 3.40 & 2.57 & 2.90 & 2.60 & 3.96 & 2.82 & 2.63 & 3.31 & 2.79 & 2.19 \\
\hline $\mathrm{Ce}$ & 13.5 & 8.7 & 11.1 & 8.7 & 11.9 & 8.2 & 8.0 & 8.1 & 12.3 & 9.5 & 8.7 & 9.4 & 9.6 & 7.7 \\
\hline $\mathrm{Sm}$ & 3.66 & 2.90 & 3.21 & 2.69 & 3.38 & 2.56 & 2.74 & 2.60 & 3.84 & 2.83 & 2.83 & 3.12 & 2.94 & 2.81 \\
\hline $\mathrm{Eu}$ & 1.44 & 1.14 & 1.21 & 1.08 & 1.13 & 0.95 & 0.98 & 1.03 & 1.35 & 1.10 & 1.03 & 1.10 & 1.05 & 1.02 \\
\hline $\mathrm{Tb}$ & 0.88 & 0.61 & 0.66 & 0.79 & 0.63 & 0.60 & 0.50 & 0.64 & 0.85 & 0.57 & 0.61 & 0.59 & 0.60 & 0.61 \\
\hline $\mathrm{Yb}$ & 2.92 & 2.19 & 2.53 & 2.19 & 2.29 & 2.00 & 2.00 & 2.06 & 3.01 & 2.30 & 2.25 & 2.37 & 2.13 & 2.32 \\
\hline $\mathrm{Lu}$ & 0.41 & 0.42 & 0.35 & 0.30 & 0.40 & 0.27 & 0.38 & 0.32 & 0.44 & 0.41 & 0.36 & 0.47 & 0.38 & 0.41 \\
\hline Hf & 2.78 & 1.90 & 2.36 & 2.09 & 2.20 & 1.86 & 1.79 & 1.82 & 2.74 & 2.22 & 2.12 & 2.27 & 2.21 & 1.99 \\
\hline $\mathrm{Ta}$ & 0.12 & 0.07 & 0.13 & 0.10 & $<0.08$ & $<0.07$ & 0.10 & $<0.07$ & 0.14 & 0.08 & 0.08 & 0.10 & 0.21 & $<0.07$ \\
\hline Th & 0.16 & ND & ND & ND & 0.26 & ND & ND & ND & ND & ND & ND & ND & ND & ND \\
\hline$(\mathrm{La} / \mathrm{Sm}) \mathrm{N}$ & 0.70 & 0.69 & 0.69 & 0.63 & 0.61 & 0.61 & 0.65 & 0.61 & 0.63 & 0.61 & 0.57 & 0.65 & 0.58 & 0.48 \\
\hline
\end{tabular}

Table 4 (continued).

\begin{tabular}{|c|c|c|c|c|c|c|c|c|c|c|c|c|c|}
\hline Hole: & $836 \mathrm{~B}$ & $837 \mathrm{~B}$ & $837 \mathrm{~B}$ & $839 \mathrm{~A}$ & 839B & $839 B$ & 839B & $839 \mathrm{~B}$ & $839 B$ & $839 B$ & $839 \mathrm{~B}$ & $839 \mathrm{~B}$ & $839 \mathrm{~B}$ \\
\hline Core, section: & $7 R-1$ & 2R-1 & $5 R-1$ & $24 X-1$ & $12 \mathrm{R}-2$ & $15 \mathrm{R}-1$ & 16R-1 & $18 \mathrm{R}-1$ & 19R-1 & 20R-1 & $23 R-1$ & 26R-1 & 28R-1 \\
\hline INAA Interval: & 22 & 49 & 9 & 19 & 20 & 27 & 60 & 38 & 59 & 81 & 7 & 18 & 18 \\
\hline Unit: & 5 & 1 & 1 & 1 & 1 & 1 & 1 & 2 & 3 & 3 & 3 & 4 & 9 \\
\hline $\mathrm{Na}$ & 1.81 & 2.25 & 1.95 & - & 1.07 & 1.17 & 1.14 & 1.45 & 1.14 & - & 1.08 & 1.03 & 1.69 \\
\hline $\mathrm{Fe}$ & 8.20 & 8.72 & 8.52 & 7.26 & 6.63 & 6.47 & 6.93 & 7.31 & 6.98 & 6.51 & 7.06 & 6.47 & 7.47 \\
\hline $\mathrm{Sc}$ & 41.0 & 33.5 & 33.3 & 42.9 & 40.6 & 40.1 & 43.1 & 35.3 & 49.7 & 35.2 & 38.2 & 44.2 & 35.8 \\
\hline $\mathrm{Cr}$ & 31 & 10 & 8 & 715 & 535 & 1113 & 1048 & 15 & 992 & 1163 & 1502 & 503 & 9 \\
\hline $\mathrm{Co}$ & 43.5 & 30.9 & 33.0 & 40,4 & 38.0 & 39.01 & 42.3 & 31.7 & 49.4 & 49.4 & 56.4 & 41.7 & 30.8 \\
\hline $\mathrm{Zn}$ & 113 & 114 & 117 & 102 & 86 & 90 & 92 & 98 & 81 & 81 & 90 & 89 & 101 \\
\hline $\mathrm{Sr}$ & 113 & 141 & 202 & 161 & 113 & - & $<160$ & 185 & $<136$ & 85 & 133 & $<133$ & 200 \\
\hline $\mathrm{La}$ & 2.54 & 3.94 & 4.14 & 1.68 & 1.82 & 1.4 & 1.64 & 2.99 & 2.44 & 2.16 & 1.98 & 1.29 & 3.60 \\
\hline $\mathrm{Ce}$ & 7.4 & 10.7 & 10.3 & 5.2 & 4.7 & 6 & 8.6 & 7.5 & 10.7 & 7.6 & 10.3 & 2.6 & 8.7 \\
\hline $\mathrm{Sm}$ & 2.54 & 3.29 & 3.70 & 1.64 & 1.70 & 1 & 1.59 & 2.39 & 1.81 & 1.57 & 1.68 & 1.46 & 2.47 \\
\hline Eu & 0.88 & 1.26 & 1.23 & 0.67 & 0.61 & 0.56 & 0.62 & 0.81 & 0.66 & 0.56 & 0.55 & 0.52 & 0.87 \\
\hline $\mathrm{Tb}$ & 0.57 & 0.76 & 0.81 & 0.37 & 0.30 & 0.4 & 0.34 & 0.52 & 0.37 & 0.36 & 0.24 & 0.28 & 0.54 \\
\hline $\mathrm{Yb}$ & 2.57 & 3.22 & 3.55 & 1.85 & 1.48 & 1.52 & 1.56 & 2.03 & 1.34 & 1.30 & 1.28 & 1.35 & 1.95 \\
\hline $\mathrm{Lu}$ & 0.49 & 0.59 & 0.70 & 0.40 & 0.27 & 0.29 & 0.24 & 0.36 & 0.29 & 0.18 & 0.26 & 0.40 & 0.38 \\
\hline Hf & 1.54 & 2.24 & 2.06 & 0.95 & 0.73 & 0.80 & 0.78 & 1.31 & 0.92 & 0.90 & 0.84 & 0.73 & 1.43 \\
\hline $\mathrm{Ta}$ & $<0.08$ & 0.10 & 0.10 & $<0.07$ & 0.07 & $<0.05$ & $<0.08$ & $<0.07$ & $<0.07$ & $<0.07$ & $<0.07$ & $<0.07$ & 0.07 \\
\hline Th & 0.16 & 0.30 & 0.24 & ND & 0.21 & $<0.2$ & ND & 0.18 & ND & ND & ND & ND & 0.35 \\
\hline$(\mathrm{La} / \mathrm{Sm}) \mathrm{N}$ & 0.61 & 0.73 & 0.68 & 0.62 & 0.65 & 0.59 & 0.63 & 0.76 & 0.82 & 0.84 & 0.72 & 0.54 & 0.89 \\
\hline
\end{tabular}

seafloor of the WEB. Parson et al. (1990) proposed that this bathymetric high was the remnant of an extinct ridge abandoned after an eastward migration (or jump) of the backarc spreading axis.

\section{Petrographic and Mineralogic Summary}

Igneous rocks recovered are sparsely to highly phyric olivine-clinopyroxene basalt that appear to constitute a single lithologic unit. There is only minor mineralogical or geochemical variation in the core even though there is considerable textural variation. Compositional data for an average of glass analyses and for the range in aphyric rock data are in Tables 2 and 3, respectively. Plagioclase is the dominant mineral; it is about twice as abundant as clinopyroxene, whereas olivine, and opaque minerals are minor constituents. Representative microprobe data are in Appendixes $\mathrm{C}-\mathrm{G}$ and Figure 2B. Textures range from slightly to highly phyric to nearly diabasic and exhibit a spectrum including these two textures as end-members. Cooling units, recognized by glass chill margins and microlitic zones, increase in thickness down section. The unit is highly vesicular $(8 \%-35 \%)$ with varying extent of infilling. Many of the largest vesicles (as large as $4 \mathrm{~mm}$ across) are partly filled with dark brownblack, quench-textured, and in some instances glassy, basalt. These segregation vesicles have crystallites of plagioclase, clinopyroxene, and magnetite. Most of the samples show at least minor effects of low-temperature alteration. The extent of alteration is in part related to texture; the finer grained rocks show only incipient alteration, whereas many of the diabasic-textured samples are more pervasively altered. These filled segregation vesicles are discussed in detail by Bloomer (this volume).

Plagioclase is the major constituent of the samples studied. It forms euhedral grains that occur as isolated grains and in glomeroporphyritic clusters with clinopyroxene. Oscillatory normal zoning is common; sodic rims are narrow and sharply defined. The compositional range is from $\mathrm{An}_{83}$ to $\mathrm{An}_{66}$, and the Or content typically is about $0.1 \%-0.2 \%$, but it does reach as high as $0.6 \%$ in one microphenocryst. The limited data show a good positive correlation between $\mathrm{FeO}^{*}$ and the Ab component.

Olivine occurs in forms similar to those at Site 834. It ranges in composition from phenocryst cores of $\mathrm{Fo}_{84}-\mathrm{Fo}_{87}$ rimmed with $\mathrm{Fo}_{83}-$ $\mathrm{Fo}_{84}$. Clinopyroxene data lie in the field for augite in the pyroxene quadrilateral (Fig. 2B). The composition ranges from $\mathrm{Wo}_{36} \mathrm{En}_{53}$ to $\mathrm{Wo}_{44} \mathrm{En}_{46}$. The data are limited, but there appears to be a good negative correlation between $\mathrm{En}$ and both $\mathrm{Na}$ and Ti. There is considerable scatter for $\mathrm{Al}$, but a negative correlation with En is also suggested. A good negative correlation exists among $\mathrm{Na}, \mathrm{Ti}$, and $\mathrm{En}$, as is seen at Site 834 . The analyzed grains show a limited range in nonquadrilateral components. $\mathrm{Al}_{2} \mathrm{O}_{3}$ varies from $2 \%$ to $4 \%, \mathrm{Na}_{2} \mathrm{O}$ is about $0.2 \%$, and $\mathrm{TiO}_{2}$ ranges from $0.3 \%$ to $0.7 \%$. $\mathrm{Cr}_{2} \mathrm{O}_{3}$ varies considerably, reaching $0.88 \%$ in some grains. In general, clinopyroxene from Site 835 compares closely with that at Sites 834 and 836 . 
Table 4 (continued).

\begin{tabular}{|c|c|c|c|c|c|c|c|c|c|c|c|c|c|c|}
\hline Hole: & 834B & $834 \mathrm{~B}$ & $834 B$ & $834 \mathrm{~B}$ & $834 \mathrm{~B}$ & $834 \mathrm{~B}$ & $834 \mathrm{~B}$ & $834 \mathrm{~B}$ & $835 \mathrm{~B}$ & $836 \mathrm{~A}$ & $836 \mathrm{~A}$ & $836 \mathrm{~A}$ & 836B & $836 \mathrm{~B}$ \\
\hline Core, section: & $37 R-1$ & $37 R-1$ & $43 R-1$ & $46 \mathrm{R}-1$ & $46 \mathrm{R}-1$ & $49 \mathrm{R}-1$ & $52 \mathrm{R}-1$ & $59 \mathrm{R}-2$ & $7 \mathrm{R}-2$ & $3 \mathrm{H}-3$ & $3 \mathrm{H}-4$ & $5 X-1$ & $3 R-1$ & $5 R-2$ \\
\hline INAA interval: & 14 & 45 & 110 & 0 & 40 & 135 & 46 & 26 & 75 & 33 & 84 & 0 & 127 & 65 \\
\hline Unit: & $9 \mathrm{~A}$ & $9 \mathrm{~B}$ & $10 \mathrm{~A}$ & $10 \mathrm{~B}$ & 11 & 12 & 12 & 13 & 1 & 1 & 2 & 3 & $4 \mathrm{~A}$ & $4 B$ \\
\hline $\mathrm{Na}$ & 2.39 & 2.41 & 3.34 & 2.70 & 1.64 & 2.82 & 2.03 & 1.84 & 1.65 & 1.82 & - & - & - & 1.60 \\
\hline $\mathrm{Fe}$ & 6.57 & 6.87 & 6.94 & 6.96 & 6.57 & 9.04 & 9.30 & 6.34 & 6.93 & 8.71 & 9.03 & 7.23 & 6.42 & 6.50 \\
\hline Sc & 32.8 & 35.1 & 23.5 & 34.4 & 37.9 & 32.4 & 31.0 & 37.0 & 38.7 & 35.0 & 37.0 & 42.5 & 44.2 & 45.4 \\
\hline $\mathrm{Cr}$ & 194 & 201 & 11 & 37 & 198 & 5 & 5 & 185 & 130 & 6 & 6 & 348 & 365 & 291 \\
\hline Co & 36.7 & 41.7 & 27.0 & 41.0 & 38.0 & 37.0 & 36.2 & 35.5 & 40.1 & 34.6 & 35.7 & 40.4 & 45.0 & 44.0 \\
\hline $\mathrm{Zn}$ & 91 & 86 & 116 & 100 & 82 & 115 & 115 & 153 & 106 & 113 & 117 & 85 & 95 & 91 \\
\hline $\mathrm{Sr}$ & $<112$ & 104 & 199 & 191 & 141 & 164 & 145 & 81 & $<123$ & 141 & 145 & ND & 368 & $<165$ \\
\hline $\mathrm{La}$ & 3.25 & 3.16 & 6.69 & 3.60 & 2.60 & 4.21 & 4.02 & 2.50 & 1.94 & 2.69 & 3.04 & 1.49 & 1.51 & 1.63 \\
\hline $\mathrm{Ce}$ & 10.7 & 10.5 & 20.6 & 10.5 & 8.0 & 13.8 & 14.4 & 9.0 & 6.0 & 8.2 & 9.7 & 4.5 & 5.1 & 5.5 \\
\hline $\mathrm{Sm}$ & 3.83 & 3.86 & 6.51 & 3.63 & 2.77 & 4.62 & 4.46 & 3.06 & 2.22 & 3.05 & 3.10 & 1.64 & 1.67 & 1.85 \\
\hline $\mathrm{Eu}$ & 1.31 & 1.34 & 1.98 & 1.25 & 1.05 & 1.60 & 1.59 & 1.11 & 0.83 & 1.09 & 1.13 & 0.69 & 0.74 & 0.77 \\
\hline $\mathrm{Tb}$ & 0.84 & 0.93 & 1.37 & 0.69 & 0.64 & 0.99 & 1.02 & 0.73 & 0.57 & 0.79 & 0.83 & 0.33 & 0.49 & 0.37 \\
\hline $\mathrm{Yb}$ & 3.16 & 3.24 & 4.83 & 2.87 & 2.28 & 3.68 & 3.64 & 2.52 & 2.20 & 3.15 & 3.66 & 1.84 & 1.87 & 1.83 \\
\hline Lu & 0.49 & 0.55 & 0.78 & 0.49 & 0.39 & 0.61 & 0.54 & 0.47 & 0.40 & 0.62 & 0.63 & 0.33 & 0.42 & 0.30 \\
\hline Hf & 2.81 & 2.84 & 5.44 & 2.49 & 1.94 & 3.41 & 3.66 & 2.21 & 1.36 & 2.00 & 2.11 & 1.06 & 1.01 & 1.16 \\
\hline $\mathrm{Ta}$ & 0.11 & 0.08 & 0.16 & 0.10 & 0.06 & 0.12 & 0.12 & $<0.07$ & $<0.07$ & 0.06 & 0.10 & $<0.07$ & $<0.07$ & 0.08 \\
\hline Th & ND & ND & 0.25 & ND & ND & ND & 0.19 & ND & ND & ND & ND & ND & ND & ND \\
\hline$(\mathrm{La} / \mathrm{Sm}) \mathrm{N}$ & 0.52 & 0.50 & 0.63 & 0.60 & 0.57 & 0.56 & 0.55 & 0.50 & 0.53 & 0.54 & 0.60 & 0.55 & 0.55 & 0.54 \\
\hline
\end{tabular}

AGV-1 Standard Analyses (Table 4, continued).

\begin{tabular}{|c|c|c|c|c|c|c|c|c|}
\hline & $\begin{array}{c}\text { AGV-1 } \\
\text { (6) } \\
\text { 1st irrad }\end{array}$ & $\begin{array}{l}\text { Error } \\
1 \mathrm{SD}\end{array}$ & $\begin{array}{c}\text { AGV-1 } \\
\text { (5) } \\
\text { 2nd irrad }\end{array}$ & $\begin{array}{l}\text { Error } \\
1 \mathrm{SD}\end{array}$ & $\begin{array}{c}\text { AGV-1 } \\
\text { (3) } \\
\text { 3rd irrad }\end{array}$ & $\begin{array}{l}\text { Error } \\
1 \mathrm{SD}\end{array}$ & $\begin{array}{l}\text { Gladney } \\
\text { Reference } \\
\text { Value }\end{array}$ & $\begin{array}{l}\text { SD of } \\
\text { reported } \\
\text { values }\end{array}$ \\
\hline $\mathrm{Na}$ & 3.18 & 0.10 & 3.15 & 0.12 & 3.12 & 0.11 & 3.15 & 0.09 \\
\hline $\mathrm{Fe}$ & 4.61 & 0.12 & 4.73 & 0.12 & 4.68 & 0.13 & 4.73 & 0.13 \\
\hline $\mathrm{Sc}$ & 11.6 & 0.3 & 12.0 & 0.2 & 11.9 & 0.3 & 12.1 & 0.9 \\
\hline $\mathrm{Cr}$ & 11 & 2 & 11 & 1 & 12 & 1 & 12 & 3 \\
\hline Co & 15.2 & 0.4 & 15.7 & 0.3 & 15.5 & 0.3 & 15.1 & 1.2 \\
\hline $\mathrm{Zn}$ & 88 & 5 & 86 & 4 & 90 & 3 & 88 & 2 \\
\hline $\mathrm{Rb}$ & 68 & 3 & 68 & 6 & 64 & 6 & 67 & 1 \\
\hline $\mathrm{Sr}$ & 709 & 40 & 708 & 29 & 713 & 40 & 662 & 9 \\
\hline $\mathrm{Ba}$ & 1210 & 26 & 1170 & 51 & 1163 & 3 & 1221 & 16 \\
\hline $\mathrm{La}$ & 38.9 & 1.0 & 38.7 & 0.7 & 38.6 & 0.4 & 38 & 3 \\
\hline $\mathrm{Ce}$ & 70.6 & 1.6 & 71.0 & 1.8 & 70.3 & 2.0 & 66 & 6 \\
\hline $\mathrm{Sm}$ & 6.12 & 0.26 & 5.96 & 0.10 & 6.06 & 0.14 & 5.9 & 0.5 \\
\hline $\mathrm{Eu}$ & 1.60 & 0.03 & 1.61 & 0.04 & 1.59 & 0.06 & 1.66 & 0.11 \\
\hline $\mathrm{Tb}$ & 0.65 & 0.04 & 0.68 & 0.04 & 0.67 & 0.10 & 0.71 & 0.10 \\
\hline $\mathrm{Yb}$ & 1.65 & 0.08 & 1.54 & 0.14 & 1.62 & 0.07 & 1.67 & 0.17 \\
\hline $\mathrm{Lu}$ & 0.250 & 0.016 & 0.242 & 0.015 & 0.244 & 0.007 & 0.28 & 0.03 \\
\hline $\mathrm{Hf}$ & 5.43 & 0.12 & 5.43 & 0.09 & 5.36 & 0.06 & 5.1 & 0.4 \\
\hline $\mathrm{Ta}$ & 0.85 & 0.03 & 0.90 & 0.04 & 0.87 & 0.02 & 0.92 & 0.12 \\
\hline Th & 6.39 & 0.14 & 6.46 & 0.21 & 6.39 & 0.17 & 6.50 & 0.37 \\
\hline $\mathbf{U}$ & 2.01 & 0.21 & 1.70 & 0.19 & 1.86 & 0.26 & 1.89 & 0.25 \\
\hline
\end{tabular}

Note: $\mathrm{SD}=$ standard deviation, and "irrad" = irradiation.

The Ti-rich magnetite is the main opaque mineral in these rocks. As at Site 834 , typically it forms skeletal to equant crystals less than $0.1 \mathrm{~mm}$ in size. These Ti-rich magnetites are similar to those typical of MORB.

\section{Site 836}

\section{Introduction}

Site 836 (Fig. 1 and Table 1) is in the western Lau Basin about 220 $\mathrm{km}$ east of the Lau Ridge and about $48 \mathrm{~km}$ west of the ELSC. The site is approximately $100 \mathrm{~km}$ south of the apex of the southward propagating rift tip of the CLSC (Parson et al., 1990, 1992). The site is in a small, elongated, oval-shaped basin about $20 \mathrm{~km}$ long and about 5 $\mathrm{km}$ wide at the $2400 \mathrm{~m}$ isobath. It trends north-northeast $\left(020^{\circ}\right)$ and is one of a number of linear depressions, bounded on the west and east by discontinuous ridges, that we interpret as horsts separating grabens and half-grabens. Unlike the other backarc sites that we assign to the WEB, Site 836 appears to be on crust formed by seafloor spreading at the ELSC. The southward propagating rift tip of the ELSC would have passed through the latitude of Site 836 at about the time assigned to the crust on the basis of paleontologic data ( $0.64-0.8$ Ma). We selected Site 836 as a likely place to sample crust that had formed shortly after a postulated ridge jump, or initiation of a new ridge, at the present location of the ELSC. Our present understanding is that rather than representing a jumped ridge, this crust formed as a consequence of the southward propagation of the ELSC into older rifted forearc or arc crust.

The relative youth of crust at this site is indicated by the overlying sedimentary sequence which extends only through the mid-Pleistocene to a depth of $20.8 \mathrm{mbsf}$. The sedimentary sequence is characterized by abundant volcaniclastic material at all depths, but in particular from about 12 mbsf downward. Rapidly deposited arc-composition basaltic andesite volcaniclastics make up as much as $50 \%$ of the lower half of the hole, with individual layers as thick as $1 \mathrm{~m}$. Accumulation of these sediments started soon after the end of basaltic volcanism that formed the igneous basement (e.g., at about 50 k.y.). An arc-composition source for these volcaniclastic sediments is indicated by their basaltic andesite composition $\left(55 \%-56 \% \mathrm{SiO}_{2}\right)$ determined by shipboard XRF analyses (Parson, Hawkins, Allan, et al., 1992) and by data presented in this volume (Bednarz and Schmincke; Clift and Dixon). Glass shards have blocky to angular shapes and low to intermediate vesicularity. They are interpreted as hyaloclastite fragments spalled off active pillowed flows, sheet flows, or both. The source of the hyaloclastite must have been less than $10 \mathrm{~km}$ away. A more detailed discussion of these volcaniclastic turbidites is in Bednarz and Schmincke (this volume). 
Table 5. Lau Basin dredge data.

\begin{tabular}{|c|c|c|c|c|c|c|c|c|c|c|c|c|c|c|}
\hline Location & $\mathrm{SiO}_{2}$ & $\mathrm{TiO}_{2}$ & $\mathrm{Al}_{2} \mathrm{O}_{3}$ & $\mathrm{FeO}^{*}$ & $\mathrm{MnO}$ & $\mathrm{MgO}$ & $\mathrm{CaO}$ & $\mathrm{Na}_{2} \mathrm{O}$ & $\mathrm{K}_{2} \mathrm{O}$ & $\mathrm{P}_{2} \mathrm{O}_{5}$ & Sum & $\mathrm{Mg} \#$ & $\mathrm{CaO} / \mathrm{Al}_{2} \mathrm{O}_{3}$ & $\begin{array}{c}\mathrm{Na}_{2} \mathrm{O} / \\
\left(\mathrm{Na}_{2} \mathrm{O}+\mathrm{CaO}\right)\end{array}$ \\
\hline \multicolumn{15}{|l|}{ ELSC: } \\
\hline $\mathrm{Mg} \#>60$, mean $(20)$ & 50.95 & 0.95 & 15.41 & 9.36 & 0.18 & 7.52 & 12.64 & 2.03 & 0.08 & 0.08 & 99.22 & 62.2 & 0.820 & 0.161 \\
\hline $\mathrm{Mg} \# 50-59$, mean (7) & 52.79 & 0.92 & 15.13 & 10.47 & 0.19 & 6.52 & 11.47 & 1.92 & 0.12 & 0.08 & 99.61 & 56.1 & 0.758 & 0.167 \\
\hline $\mathrm{Mg \#}<50$, mean $(2)$ & 52.79 & 1.85 & 14.08 & 13.62 & 0.21 & 4.28 & 8.90 & 3.03 & 0.16 & 0.19 & 99.09 & 39.2 & 0.632 & 0.254 \\
\hline \multicolumn{15}{|l|}{ CLSC: } \\
\hline Mg\# $>60$, mean (5) & 49.15 & 0.99 & 16.97 & 9.19 & 0.18 & 8.48 & 12.14 & 2.57 & 0.11 & 0.07 & 99.88 & 65.4 & 0.715 & 0.212 \\
\hline $\mathrm{Mg} \# 50-59$, mean $(17)$ & 52.04 & 1.24 & 14.46 & 10.70 & 0.20 & 6.71 & 11.37 & 2.53 & 0.14 & 0.10 & 99.67 & 56.2 & 0.786 & 0.223 \\
\hline $\mathrm{Mg} \# 40-49$, mean $(10)$ & 50.81 & 1.94 & 13.41 & 14.10 & 0.26 & 5.63 & 10.21 & 2.88 & 0.12 & 0.16 & 99.55 & 45.0 & 0.761 & 0.282 \\
\hline $\mathrm{Mg} \#<40$, mean $(7)$ & 53.76 & 2.07 & 13.01 & 14.44 & 0.24 & 3.82 & 8.34 & 3.27 & 0.26 & 0.28 & 99.56 & 35.2 & 0.641 & 0.392 \\
\hline \multicolumn{15}{|l|}{ Old crust: } \\
\hline RNDB 2-5GL & 56.43 & 1.53 & 14.06 & 13.14 & 0.20 & 3.91 & 8.53 & 1.68 & 0.29 & 0.15 & 99.92 & 37.9 & 0.607 & 0.197 \\
\hline RNDB 2-7GL & 55.86 & 1.20 & 14.95 & 11.32 & 0.22 & 3.87 & 8.32 & 2.91 & 0.24 & 0.15 & 99.20 & 41.2 & 0.557 & 0.350 \\
\hline RNDB $2-8 \mathrm{GL}$ & 56.43 & 1.25 & 14.14 & 12.19 & 0.22 & 3.72 & 8.14 & 2.41 & 0.29 & 0.14 & 99.11 & 38.5 & 0.576 & 0.296 \\
\hline 7-TOW 74-1 & 50.24 & 0.76 & 15.80 & 9.13 & 0.21 & 7.39 & 13.37 & 2.10 & 0.11 & 0.09 & 99.20 & 62.4 & 0.846 & 0.157 \\
\hline ANT 225-1 & 53.59 & 1.05 & 14.56 & 11.55 & 0.21 & 5.27 & 10.22 & 2.34 & 0.17 & 0.11 & 99.07 & 48.3 & 0.702 & 0.229 \\
\hline ANT 223-1 & 50.89 & 1.32 & 17.10 & 8.01 & 0.17 & 6.35 & 11.06 & 3.23 & 0.38 & 0.23 & 98.79 & 61.9 & 0.647 & 0.292 \\
\hline P34-1 & 49.18 & 0.79 & 15.58 & 10.91 & 0.20 & 6.97 & 13.38 & 1.90 & 0.17 & 0.08 & 99.16 & 56.7 & 0.859 & 0.142 \\
\hline P $34-2$ & 49.59 & 0.87 & 15.65 & 11.20 & 0.19 & 6.76 & 12.85 & 1.99 & 0.15 & 0.19 & 99.44 & 55.3 & 0.821 & 0.155 \\
\hline \multicolumn{15}{|l|}{ Relay zone: } \\
\hline RNDB $12-1 \mathrm{GL}$ & 48.78 & 0.47 & 15.42 & 6.33 & 0.13 & 6.80 & 10.68 & 1.54 & 0.30 & 0.06 & 90.51 & 68.8 & 0.693 & 0.144 \\
\hline RNDB $12-6 \mathrm{GL}$ & 53.00 & 0.57 & 16.20 & 7.95 & 0.14 & 6.89 & 12.28 & 1.54 & 0.32 & 0.10 & 99.00 & 64.0 & 0.758 & 0.125 \\
\hline RNDB 31-1GL & 51.44 & 1.21 & 15.31 & 10.61 & 0.22 & 6.28 & 11.61 & 2.54 & 0.08 & 0.07 & 99.37 & 54.8 & 0.758 & 0.219 \\
\hline RNDB $31-4 \mathrm{GL}$ & 49.25 & 0.79 & 17.36 & 8.65 & 0.17 & 9.10 & 12.82 & 2.20 & 0.03 & 0.03 & 100.41 & 68.3 & 0.738 & 0.172 \\
\hline
\end{tabular}

Note: Data from Hawkins $(1976,1988,1989)$.

\section{Petrographic and Mineralogic Summary}

Five igneous rock units were identified on the basis of mineralogy, mineral proportions, and texture in the two holes drilled at Site 836. Units 1 and 2 are fresh, glassy, sparsely phyric andesitic hyaloclastites. The fragments are vesicular; many are markedly angular, with sharp conchoidal fractures, and preserve delicate fine textured vesicles. The textural preservation of the clasts suggests that they have experienced little transport or reworking and a nearby source is inferred. Units 3-5 are sparsely to moderately phyric, multiply-saturated basalts. Unit 3 comprises plagioclase-clinopyroxene basalt fragments intercalated with sediment. Unit 4, an aphyric holocrystalline, seriate-textured to ophitic-textured basalt, was subdivided into Sub-units $4 \mathrm{~A}$ and $4 \mathrm{~B}$, both petrographically similar, on the basis of a sedimentary interbed. Unit 5 has phenocrysts of plagioclase $>$ clinopyroxene $>$ olivine together, constituting 2-5 modal\% of the rocks. The shipboard XRF data indicate that Units 3 and 4 are olivine-normative tholeiites and Unit 5 is quartz-normative, verging on a basaltic andesite. All of the basalts of Units 3-5 are moderately to highly vesicular (e.g., 14-36 modal\% vesicles). All of the samples recovered are relatively unaltered. Some representative data for glasses and rocks from the various units are in Tables 2 and 3. The complete data set is in Appendixes A and B, and representative microprobe data for the primary minerals are in Appendixes $\mathrm{C}-\mathrm{G}$ and Figure $2 \mathrm{~B}$.

Plagioclase is a major constituent that occurs as phenocrysts and microphenocrysts, in glomeroporphyritic intergrowths with clinopyroxene, and as quench-textured microlites in glass rinds. Most of the grains have normal, oscillatory zoning with sharply defined, narrow sodic rims. Our microprobe data are limited to Units 4 and 5. Plagioclase composition ranges from cores of $\mathrm{An}_{87}$ (Subunit 4B) to an interior zone of $\mathrm{An}_{29}$ in Subunit 4A. Grain-rim compositions vary widely from $\mathrm{An}_{72}$ (Unit 5) to $\mathrm{An}_{46}$ (Subunit 4B). As with the other sites, a good positive correlation exists between $\mathrm{FeO}^{*}$ and the ratio $\mathrm{Na} /(\mathrm{Na}+\mathrm{Ca})$.

Olivine is present as a minor phase; it forms both phenocrysts and groundmass material in Units 3 and 4. Orthopyroxene was identified in Unit 2.

Clinopyroxene forms rare phenocrysts in Units 4 and 5 and is a groundmass component in Units 3-5. Microprobe data for Units 4 and 5 are presented in Appendix D and shown in Figure 2B. The clinopyroxene is mainly augite, but some analyses lie in the endiop- side field. There are negative correlations between En and the nonquadrilateral components with $\mathrm{Na}$ and $\mathrm{Ti}$ giving the strongest trends. Site 836 clinopyroxene has variable nonquadrilateral components (e.g., $\mathrm{Al}_{2} \mathrm{O}_{3} 1.2 \%-4.5 \%, \mathrm{TiO}_{2} 0.3 \%-1.1 \%$, and $\mathrm{Na}_{2} \mathrm{O} 0.1 \%-0.2 \%$ ). Most grains have low $\mathrm{Cr}$, ranging from 70 to $890 \mathrm{ppm}$, but two grains in Unit 4 have up to $1800 \mathrm{ppm}$.

The Cr-rich spinel typically is euhedral and commonly occurs disseminated through the rock or included in olivine or plagioclase. Epitaxial attachment of spinel to olivine or plagioclase is also found. Site 836 spinel has substantially less $\mathrm{TiO}_{2}(0.37 \%-0.56 \%)$ than spinels from Site 834 (e.g., Analysis 3, Appendix F). This must reflect fundamental differences in $\mathrm{TiO}_{2}$ in the parental magmas. An extensive discussion of the spinels is given by Allan (this volume). The Ti-rich magnetites are common but of low abundance in Site 836 rocks. Site 836 Ti-magnetite (Appendix G) is similar to that typical of MORB.

The age of the igneous units is well constrained by paleontologic dating of intercalated sediments. Units 2 and 3 are interbedded with, and Units 3-5 are overlain by, sediments with a maximum age of middle Pleistocene (e.g., 0.64 Ma). It may be significant that the basal sediments are nannofossil ooze with thin discontinuous layers of angular fragments of mafic rock. Much more voluminous volcaniclastic sedimentation began at about $0.6 \mathrm{Ma}$. Volcaniclastic sediments with abundant glass shards are a major constituent of the Site 836 sediments. They are interpreted as basaltic andesite hyaloclastites (56\%-58\% $\mathrm{SiO}_{2}$ ) derived from proximal sources. Rocks dredged from a nearby ridge, about $5 \mathrm{~km}$ to the east (Scripps Institution of Oceanography, ROUNDABOUT Expedition dredge RNDB-15-02; Hawkins, 1989) have $54 \% \mathrm{SiO}_{2}$ and $4.2 \% \mathrm{MgO}$.

\section{Sites $\mathbf{8 3 7}, \mathbf{8 3 8}$, and $\mathbf{8 3 9}$}

\section{Introduction}

These three sites will be discussed together because the sample recovery at Sites 837,838 , and 839 was limited and all three share a common setting as part of the WEB. All three sites are in narrow linear sub-basins in the central Lau Basin between $20^{\circ}$ and $21^{\circ} \mathrm{S}$. Crustal ages were expected to be on the order of $2 \mathrm{Ma}$ based on magnetic anomaly patterns. The sites were picked to give information about crustal age and composition in the zone of transition between older rifted crust and the younger crust formed at the ELSC. 
A

\section{SITE 834}

$+12 \mathrm{X}-\mathrm{CC}, 02 \mathrm{~cm} \mathrm{PH}$

- $13 \mathrm{X}-1,24 \mathrm{~cm} \mathrm{PH}$

- $13 X-1,24 \mathrm{~cm}$ MIC

- $30 \mathrm{R}-3,105 \mathrm{~cm} \mathrm{OPH}$

- $43 \mathrm{R} 1 / 107 \mathrm{~cm}$ MIC

- 47R-1, $130 \mathrm{~cm}$ MIC

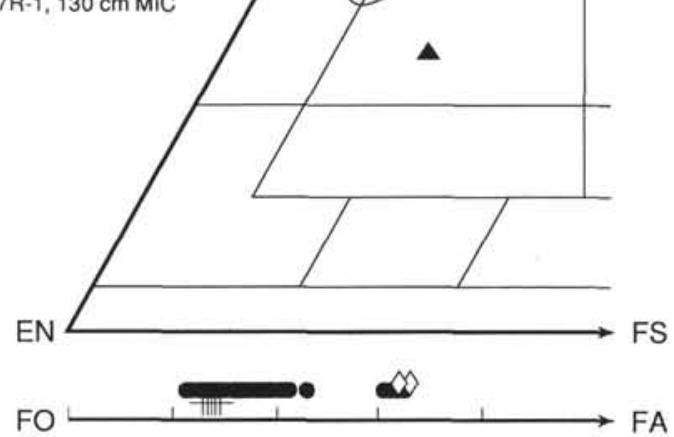

B

\section{SITE 835}

- $3 \mathrm{R}-1,137 \mathrm{~cm}$ PH

- $3 \mathrm{R}-2,104 \mathrm{~cm}$ MIC

SITE 836

- $3 \mathrm{R} \cdot 2,93 \mathrm{~cm}$ PH

- $5 \mathrm{R}-2,92 \mathrm{~cm} \mathrm{PH}$

$+7 R-1,31 \mathrm{~cm} \mathrm{MIC}$

- $9 \mathrm{M}-1,47 \mathrm{~cm}$ PH
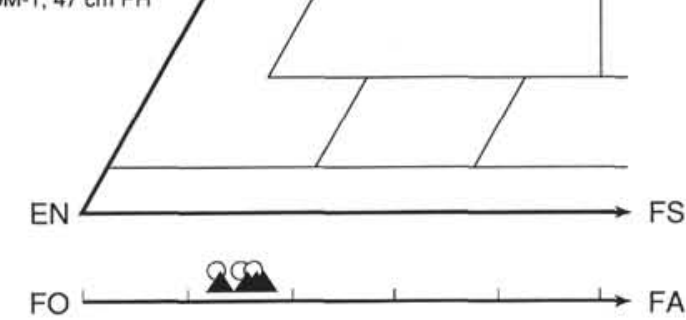

\section{SITE 839}

- $18 \mathrm{R}-1,54 \mathrm{~cm}$ MIC

- $26 \mathrm{R}-1,23 \mathrm{~cm} \mathrm{PH}$

- $27 \mathrm{R}-1,15 \mathrm{~cm} \mathrm{PH}$

- $30 \mathrm{R}-1,74 \mathrm{~cm}$ MIC

+ $22 \mathrm{R}-1,24 \mathrm{~cm} \mathrm{PH}$

- $27 \mathrm{R}-1,15 \mathrm{~cm}$ PH

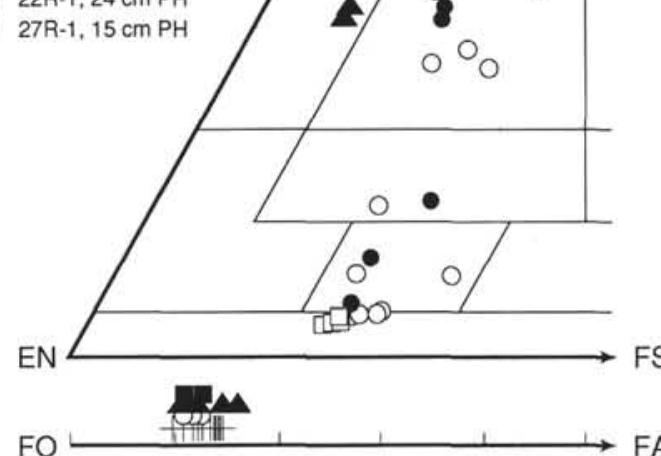

D

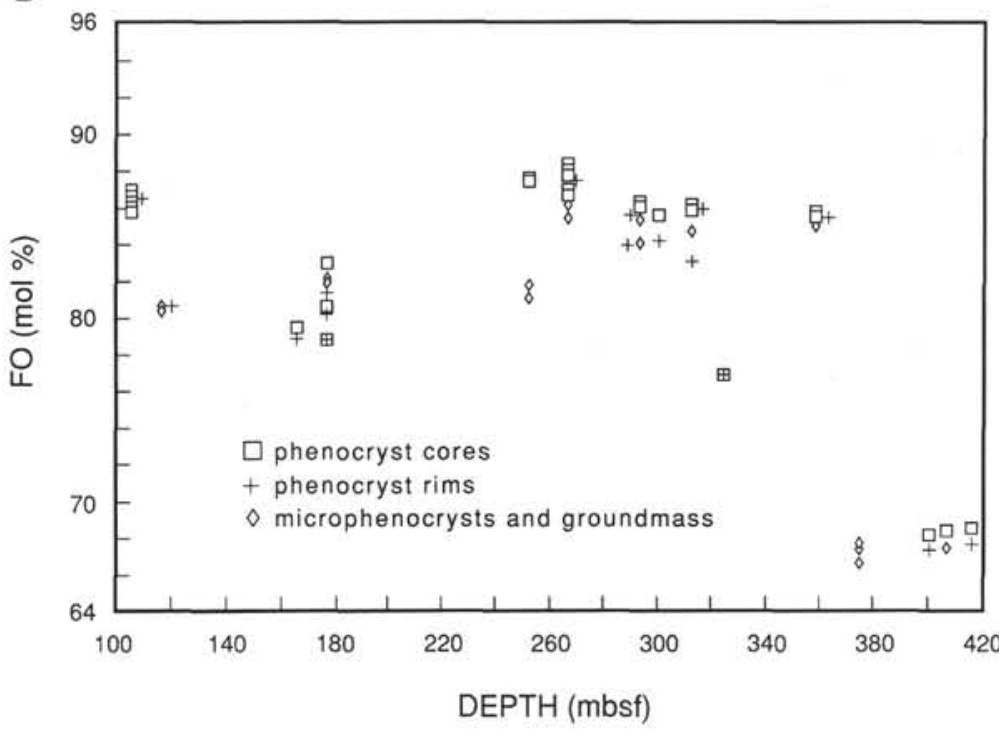

Figure 2. Electron microprobe data for representative minerals from drill cores. A. Pyroxene data plotted on pyroxene quadrilateral. WO=wollastonite, $\mathrm{EN}=\mathrm{enstatite,}$ $\mathrm{FS}=$ ferrosilite, $\mathrm{DI}=$ diopside, and $\mathrm{HD}=$ hedenbergite. Circled field for Site 834 encloses 81 data points. Symbols are for young flow (Unit 2, 135-834A-13X-2, 24 $\mathrm{cm}$ ) and least fractionated deep unit (Unit 12, 135-834B-47R-1, $130 \mathrm{~cm}$ ). Data lying outside main field are shown also. Data for coexisting olivine are shown on bottom of diagram. B. Pyroxene and olivine data for Sites 835 and 836. C. Pyroxene and olivine data for Site 839. D. Olivine data, Site 834, for phenocryst cores, rims, and microphenocrysts vs. depth in hole. Fo = forsterite.

Site 837 is about $70 \mathrm{~km}$ west of the axial zone of the ELSC and about $175 \mathrm{~km}$ west of the Tofua Arc. A single, basaltic andesite igneous unit was recognized in Hole 837B. The oldest sediments at the site are latest Pliocene (about $2 \mathrm{Ma}$ ). They are dominated by epiclastic deposits that are predominantly gravity-flow deposits of volcaniclastic sediments. Pyroclastic sediments are much less abundant. Glass shards in the sediment show a bimodal distribution of compositions in which high-silica glasses $\left(70 \%-71 \% \mathrm{SiO}_{2}\right)$ predominate over more mafic glasses $\left(52 \%-54 \% \mathrm{SiO}_{2}\right)$. The source may have been an arc, but it is not clear where the arc was located. Fryer et al. (1990) show that rifting of the Izu-Bonin Arc to form the Sumisu and Toroshima backarc rift basins resulted in bimodal basaltic/rhyolitic volcanism. The bimodal glass compositions at Site 837 may represent similar processes in the development of small rift basins that preceded seafloor spreading in the Lau Basin.

Site 838 is about $87 \mathrm{~km}$ west of the ELSC and $155 \mathrm{~km}$ west of the Tofua Arc. The site lies close to the arbitrary line separating the part of the Lau Basin, to the east, that probably formed by seafloor spreading from the basin-range structure (WEB) to the west. The only igneous rocks recovered were clasts in polymict volcanic gravels. The oldest sediments recovered at this site are latest Pliocene (about $2 \mathrm{Ma}$ ) that include polymict volcanic gravels interbedded with volcaniclastic sandstones and vitric clayey siltstone.

Site 839 is about $70 \mathrm{~km}$ west of the ELSC and $140 \mathrm{~km}$ from the Tofua Arc. The oldest sediments, interbedded with igneous rocks, are late Pliocene in age, about $1.9 \mathrm{Ma}$.

\section{Petrographic and Mineralogic Summary}

\section{Site 837}

Igneous rock recovery was limited to about $4 \mathrm{~m}$ of sparsely to moderately phyric, orthopyroxene-clinopyroxene-plagioclase basaltic andesite. Some representative data for these rocks are in Tables 3 
Table 6. Lithologic units, Site 834.

\begin{tabular}{|c|c|c|c|}
\hline \multirow{2}{*}{$\begin{array}{l}\text { Unit and } \\
\text { lithology }\end{array}$} & \multirow{2}{*}{$\begin{array}{l}\text { Phenocryst } \\
\text { (modal \%) }\end{array}$} & \multicolumn{2}{|c|}{ Phases present } \\
\hline & & Groundmass (\%) & $\operatorname{Vesicle}(\%)$ \\
\hline Unit 1 & $0 \%-2 \%$ & $55 \%-95 \%$ & $10 \%-45 \%$ \\
\hline $\begin{array}{l}\text { Aphyric to plagioclase- } \\
\text { bearing basalt }\end{array}$ & Plag $>$ OI & $\begin{array}{l}\text { Plag }>\text { Cpx }>\mathrm{Ol} \\
\text { + mesostasis }\end{array}$ & $<1 \mathrm{~mm}$ \\
\hline Unit 2 & Trace & $65 \%-80 \%$ & $20 \%-35 \%$ \\
\hline Aphyric basalt & Plag $>\mathrm{Cpx}$ & Plag $>\mathrm{Cpx} \gg \mathrm{Ol}$ & $<2 \mathrm{~mm}^{*}$ \\
\hline Unit 3 & $3 \%-5 \%$ & $60 \%$ & $30 \%-35 \%$ \\
\hline $\begin{array}{l}\text { Moderately phyric } \\
\text { plagioclase basalt }\end{array}$ & Plag & $\begin{array}{l}\text { Plag }=\text { Cpx } \\
\text { + mesostasis }\end{array}$ & $<3 \mathrm{~mm}$ \\
\hline Unit 4 & $0 \%-1 \%$ & $60 \%-65 \%$ & $35 \%-40 \%$ \\
\hline Aphyric basalt & Plag & $\begin{array}{l}\text { Plag }>\mathrm{cp} \\
+ \text { mesostasis }\end{array}$ & $<3.5 \mathrm{~mm}$ \\
\hline Unit 5 & $1 \%-2 \%$ & $80 \%-85 \%$ & $10 \%-20 \%$ \\
\hline $\begin{array}{l}\text { Aphyric, poikilitic } \\
\text { plagioclase basalt }\end{array}$ & Plag & $\begin{array}{l}\text { Plag }>\mathrm{cp} \\
+ \text { minor } \\
\text { mesostasis }\end{array}$ & $<6 \mathrm{~mm}$ \\
\hline Unit 6 & Trace & $50 \%-70 \%$ & $30 \%-50 \%$ \\
\hline $\begin{array}{l}\text { Aphyric to sparsely } \\
\text { phyric basalt }\end{array}$ & Plag $>\mathrm{Cpx}$ & $\begin{array}{l}\text { Plag }>\text { Cpx }>\mathrm{Ol} \\
+ \text { mesostasis }\end{array}$ & $<1.5 \mathrm{~mm}^{*}$ \\
\hline Unit 7 & $10 \%-25 \%$ & $75 \%-90 \%$ & Nonvesicular \\
\hline $\begin{array}{l}\text { Moderately to highly } \\
\text { phyric plagioclase basalt }\end{array}$ & Plag $\gg$ Cpx & $\begin{array}{l}\text { Plag }>\text { Cpx }> \\
+ \text { mesostasis }\end{array}$ & $>\mathrm{Ol}$ \\
\hline Unit 8 & Trace & $60 \%-80 \%$ & $20 \%-45 \%$ \\
\hline Aphyric basalt & Plag $>\mathrm{Cpx}$ & $\begin{array}{l}\text { Plag }>\text { Cpx } \\
+ \text { mesostasis }\end{array}$ & $<6 \mathrm{~mm}^{*}$ \\
\hline Unit 9 & $5 \%-11 \%$ & $60 \%-80 \%$ & $7 \%-20 \%$ \\
\hline $\begin{array}{l}\text { Moderately phyric } \\
\text { olivine-plagioclase ba- } \\
\text { salt }\end{array}$ & Plag $>\mathrm{Ol}$ & $\begin{array}{l}\text { Plag }>\text { Cpx } \gg \text { Ol } \\
\text { + mesostasis }\end{array}$ & $<1 \mathrm{~mm}^{*}$ \\
\hline Unit 10 & None & $70 \%-85 \%$ & $15 \%-30 \%$ \\
\hline Aphyric basalt & & $\begin{array}{l}\text { Plag }>\text { Cpx }>\text { Ol } \\
+ \text { mesostasis }\end{array}$ & $<6 \mathrm{~mm}^{*}$ \\
\hline Unit 11 & & & \\
\hline $\begin{array}{l}\text { Sparsely phyric } \\
\text { olivine-plagioclase ba- } \\
\text { salt }\end{array}$ & No data & No data & \\
\hline Unit 12 & $0 \%-15 \%$ & $75 \%-90 \%$ & $10 \%$ \\
\hline $\begin{array}{l}\text { Aphyric to moderately } \\
\text { phyric plagioclase basalt }\end{array}$ & Plag $>\mathrm{Cpx}$ & $\begin{array}{l}\text { Plag }>\text { Cpx } \\
+ \text { mesostasis }\end{array}$ & $<1 \mathrm{~mm}^{*}$ \\
\hline Unit 13 & $<5 \%$ & $50 \%-60 \%$ & $30 \%-35 \%$ \\
\hline Moderately phyric & $\begin{array}{l}\text { Plag }>\mathrm{Ol}> \\
\text { Cpx }\end{array}$ & Plag $>\mathrm{Cpx}>\mathrm{Ol}$ & $<2 \mathrm{~mm}^{*}$ \\
\hline $\begin{array}{l}\text { olivine-clinopyroxene- } \\
\text { plagioclase basalt }\end{array}$ & & + mesostasis & \\
\hline
\end{tabular}

Notes: $\mathrm{Plag}=$ plagioclase, $\mathrm{Ol}=$ olivine, and $\mathrm{Cpx}=$ clinopyroxene. An asterisk

$\left({ }^{*}\right)$ indicates that patches of quenched vesicular material fill some vesicles.

and 4 and in Appendix B. Orthopyroxene is present only in trace amounts; plagioclase phenocrysts are more abundant than clinopyroxene, but both constitute only about 2 modal\%. Vesicle content ranges from $15 \%$ to $20 \%$.

\section{Site 838}

About $1.7 \mathrm{~m}$ of volcanic gravel with clasts of aphyric to sparsely phyric clinopyroxene-plagioclase basalt and basaltic andesite provided the only igneous rocks from this site. Representative analyses of glass are in Table 2 and the complete set of analyses is in Appendix A. Some of the fragments are highly vesicular with up to $40-60$ modal $\%$ of tiny vesicles that give the clasts a spongy texture. Clasts with larger vesicles (e.g., as large as $2.5 \mathrm{~mm}$ diameter) have on the order of $10 \%$ vesicles.

\section{Site 839}

Nine lithologic units were recognized in the $292 \mathrm{~m}$ of core recovered. Rocks at this site are distinctive in having several lithologic units with orthopyroxene as a phenocryst phase. The $\mathrm{Cr}$-spinel, some of it xenocrystic, also is distinctive. The lowermost half of the cored interval comprises a series of phyric clinopyroxene-orthopyroxene-plagioclase basaltic andesite flows with high plagioclase/pyroxene ratios. The upper part of the core has aphyric to sparsely phyric olivine-clinopyroxene basalts and basaltic andesites and highly phyric clinopyroxene-olivine basalts. Representative glass and bulk-rock analyses are in Tables 2-4. The complete data set is in Appendixes A and B. Representative microprobe data for the minerals are in Appendixes $\mathrm{A}-\mathrm{G}$ and Figure $2 \mathrm{C}$.

Unit 1 comprises $42 \mathrm{~m}$ of aphyric to moderately phyric clinopyroxene-olivine basalt having only a small number of cooling units. Unit 2 is moderately phyric orthopyroxene-clinopyroxene-plagioclase basaltic andesite. Unit 3 is sparsely to highly phyric clinopyroxene-olivine basalt. Unit 4 is aphyric to sparsely phyric olivineclinopyroxene basalt. Unit 5 is moderately phyric orthopyroxeneclinopyroxene-plagioclase basaltic andesite. Unit 6 is moderately to highly phyric clinopyroxene-olivine basalt. Unit 7 is moderately phyric clinopyroxene-orthopyroxene-plagioclase basaltic andesite. Unit 8 is moderately to highly phyric clinopyroxene-olivine basalt. Unit 9 is moderately to highly phyric clinopyroxene-orthopyroxene-plagioclase basaltic andesite. Except for moderate alteration of Unit 1, the rocks are remarkably fresh.

As for the other backarc sites, the rocks are dominated by plagioclase and clinopyroxene with varied amounts of olivine. The presence of orthopyroxene, strongly zoned olivine and plagioclase and, in some samples, abundant $\mathrm{Cr}$-spinel, makes the Site 839 samples somewhat anomalous for the Lau Basin. Plagioclase forms phenocrysts, microphenocrysts and groundmass that range in composition from rims of $\mathrm{An}_{70}$ to cores of $\mathrm{An}_{90}$. The $\mathrm{K}$ content is low and Or rarely exceeds $0.4 \%$. Olivine occurs as xenocrysts, phenocrysts, and microlites. Probable xenocrystic olivine, having cores of $\mathrm{Fo}_{88}$ to $\mathrm{Fo}_{90}$, have sharply defined rims with $\mathrm{Fo}_{83}$ to $\mathrm{Fo}_{87}$. The $\mathrm{Fe}$-rich rims commonly are only a few microns wide. These rims are in apparent equilibrium with the host glasses whereas the cores are not. Orthopyroxene compositions generally parallel the olivine with a range from $\mathrm{En}_{74} \mathrm{Wo}_{3.3}$ to $\mathrm{En}_{59}$ $\mathrm{Wo}_{9}$. Clinopyroxene is augite and endiopside. The $\mathrm{Cr}$-spinel occurs in two forms: as relatively small $(5-100 \mu \mathrm{m})$ euhedral inclusions in olivine crystals or as loose individual crystals or crystal clumps that may reach sizes of $3 \mathrm{~mm}$ or more in Units 1 and 3. These large crystals are euhedral where present in the glass of Unit 3, but become increasingly rounded, embayed, and resorbed as the groundmass becomes coarser, particularly in diabasic Unit 1 . There are no consistent compositional differences between the large groundmass crystals and the smaller inclusions, however many large spinels have cores with high $\mathrm{Cr} /(\mathrm{Cr}+\mathrm{Al})$ suggesting that they may be xenocrystic. $\mathrm{TiO}_{2}$ is noticeably low in the $\mathrm{Cr}$-spinels (Appendix F) presumably reflecting the low $\mathrm{TiO}_{2}$ of the host rocks.

A striking feature of the spinels from Units 1 and 3 is the great range shown in their divalent cation composition; $\mathrm{Mg} \#(\mathrm{Mg} /(\mathrm{Mg}+\mathrm{Fe}))$ ranges from 0.27 to 0.75 ). Divalent cation zoning in the large spinels typically is profound in the coarse-grained groundmass crystals (e.g., Analyses 4 and 5 in Appendix $\mathrm{F}$ are from a core-rim pair); zoning is still substantial when the spinel lies within quench glass or fine-grained mesostasis (Analyses 6 and 7, Appendix F). In contrast, their zoning in the trivalent cations is minimal (Appendix F) despite the strong energetic coupling of $\mathrm{Mg}-\mathrm{Al}$ and $\mathrm{Fe}^{2+}-\mathrm{Cr}$ into the spinel structure. This type of zoning, where divalent cations are mobile and trivalent cations are not, is similar to that observed within spinels that have undergone reequilibration during metamorphism or hydrothermal alteration. Experimental evidence for crystallization of these spinels bears out the conclusion that this zoning is related to reequilibration and not to crystallization (Forsythe and Fisk, this volume; and Allan; this volume). The cores of these large spinels contain very high $\mathrm{Mg \#}$ up to 0.80 ), as do many of the spinel inclusions within the centers of the larger olivines. These spinels crystallized from silicate liquids with $\mathrm{Mg}$ \# of up to 0.80 (Allan, this volume), indicating profound disequilibrium between them and the host liquids within which they are found (glass compositions of Unit 3 have Mg\# of 0.62-0.63). 


\section{PETROLOGY OF THE CENTRAL AND EASTERN LAU SPREADING CENTERS}

Generation of new ocean crust by seafloor spreading, occurs at the Central and Eastern Lau Spreading Centers and on the three segments of the Mangatolu Triple Junction in the northeastern Lau Basin (Hawkins and Melchior, 1985: Hawkins et al., 1989; Nilsson et al., 1989; Nilsson, 1993). The CLSC and ELSC lie east of the Leg 135 backarc drill sites, yet their dredged rocks show many compositional similarities to the core samples we studied. Sites 834 and 835 lie on a time "flow line" west of the CLSC, but it is not likely that rocks from the drill sites are directly related to the much younger CLSC. However, crust drilled at Site 836 most likely formed at the ELSC, and much similarity exists between Site 835 and the ELSC.

The western Lau Basin is dominated by small elongated basins, separated by high-standing blocks, that give the area a basin-range type morphology. There is a major change in the geology of the basin near $176^{\circ} 30^{\prime} \mathrm{W}$, some $150 \mathrm{~km}$ east of Site 834 , as evidenced by bathymetry, magnetic anomaly patterns, dredged rocks, and GLORIA imagery. These changes mark the location of the CLSC, which is one of the major morphologic-tectonic-petrologic features of the Lau Basin. It overlaps the ELSC near $19^{\circ} 15^{\prime} \mathrm{S}$ (Parson et al., 1990). Together, the CLSC and ELSC are the main sites of magma leakage and backarc spreading presently forming new Lau Basin crust near our drill sites. The ELSC is the older system of the two having started as a propagating rift near the southeastern end of the Peggy Ridge at about 4.5-5.0 Ma (Parson and Hawkins, this volume). As discussed in a previous section, rift propagation, and beginning of seafloor spreading, were contemporary with crustal rifting and extension in the western basin. The bathymetric and magnetic patterns of the CLSC indicate that it is propagating southward into older Lau Basin crust originally formed by the ELSC. In the overlap zone, there are offsets in magnetic patterns and bathymetry that are interpreted as pseudofaults. The relay zone between the two ridges has a complex fabric with both nodal basins and small positive features. The age of the CLSC is equivocal because the older magnetic anomaly patterns are unclear, but the propagator appears to have started near the southeastern end of the Peggy Ridge at about 1.5-1.2 Ma and has advanced southward, forming an overlap system with the ELSC, which is dying southward (Parson and Hawkins, this volume). Presently, the propagator tip is at $19^{\circ} 16^{\prime} \mathrm{S}, 176^{\circ} 32^{\prime} \mathrm{W}$, some $120 \mathrm{~km}$ east of Site 834. The ELSC also is propagating southward and is nearly parallel to the Tofua Arc for over $180 \mathrm{~km}$. The northern end is at $19^{\circ} 20^{\prime} \mathrm{S}$, and the southern end is at $21^{\circ} \mathrm{S}$, where it merges with the Valu Fa Ridge.

Rocks forming these active ridges have a MORB-like character (e.g., Hawkins, 1974, 1976, 1977, 1988, 1989; Hawkins and Melchior, 1985; Hawkins et al., 1989; Volpe et al., 1988; Sunkel, 1990; Loock, 1990; Falloon et al,, in press; Ernewein et al., in press). Major element data for glasses are plotted vs. $\mathrm{MgO}$ in Figure 3 and compared with fields for MORB, arcs, and the Mariana Trough axial ridge. These plots show that the Mariana Trough backarc basin glasses are intermediate to arc and MORB for $\mathrm{Al}_{2} \mathrm{O}_{3}, \mathrm{FeO}^{*}$, and $\mathrm{TiO}_{2}$, whereas $\mathrm{Na}_{2} \mathrm{O}$ and $\mathrm{K}_{2} \mathrm{O}$ are significantly higher than MORB. $\mathrm{CaO}$ is essentially like MORB. The Lau Basin axial ridges each define fields with some overlap, but both are closer to MORB than are the Mariana Trough data. The CLSC and ELSC fields for $\mathrm{CaO}$ and $\mathrm{K}_{2} \mathrm{O}$ show no difference from MORB; $\mathrm{P}_{2} \mathrm{O}_{5}$ (not shown) also overlaps MORB. The CLSC data for $\mathrm{Al}_{2} \mathrm{O}_{3}, \mathrm{FeO}^{*}$, and $\mathrm{TiO}_{2}$ show considerable overlap with MORB; however, many of the ELSC data are displaced from the MORB fields and overlap with the Mariana Trough glasses. $\mathrm{TiO}_{2}$ for the ELSC lies in the Mariana Trough field with some overlap onto the arc field; $\mathrm{Na}_{2} \mathrm{O}$ is intermediate between MORB and Mariana Trough. The CLSC glasses have $\mathrm{Na}_{2} \mathrm{O}$ that plots on the Mariana Trough field.

The chemical distinctions discussed above (and given in Table 5) set the Lau Basin axial ridges apart from N-MORB sensu strictu, yet they are distinct from arc tholeiites as well. Some of these differences are seen in Figure 4, in which trace element data for the CLSC and ELSC are normalized to N-MORB. Relative depletions in highfield-strength elements (HFSE), especially $\mathrm{Nb}$ and $\mathrm{Ta}$, are seen for both ridges. The ELSC shows selective enrichment in some large ionic radius lithophile elements (LILE) and light rare-earth elements (LREE). These are considered to be SSZ or arc signatures, although the scale of these depletions or enrichments does not reach arc levels.

Isotope data are limited but suggest that both ridge systems have MORB-like $\mathrm{Nd}, \mathrm{Pb}, \mathrm{He}$, and $\mathrm{O}$ ratios, whereas the $\mathrm{Sr}$ ratios are more radiogenic than MORB (e.g., 0.7030-0.7035) and may have an affinity to an "Indian Ocean" mantle source (Volpe et al., 1988; Poreda, 1985; Loock et al., 1990; Boespflug et al., 1990). In a section that follows, we will show that in this respect they differ from Site 834 lavas, but are similar to Site 836 (Hergt and Hawkesworth, this volume).

In summary, both the Mariana Trough and Lau Basin axial ridges differ slightly from N-MORB in their abundances of oxides of $\mathrm{Al}, \mathrm{Fe}$, $\mathrm{Ti}$, and $\mathrm{Na}$, but they are more similar to MORB than to arc lavas. In addition, these two backarc basins each have their own chemical signatures as a result of an imprint from SSZ mantle sources.

Both of the Lau Basin spreading centers are petrologically similar, even though they differ somewhat in chemistry as discussed above (see also data in Table 5). Rocks collected on the ridge axes, and from within $50 \mathrm{~km}$ of the axial zones, are mainly aphyric to sparsely phyric, vesicular, tholeiitic basalt. The vesicularity is a major textural feature found throughout the Lau Basin and is common in the Mariana Trough rocks as well. Mineralogically, the ELSC and CLSC rocks are largely olivine-plagioclase-clinopyroxene basalts. Chrome-spinel, sulfides of $\mathrm{Fe}, \mathrm{Cu}-\mathrm{Fe}$, and $\mathrm{Fe}-\mathrm{Ni}$, and oxides (ilmenite and $\mathrm{Ti}$-magnetite) are minor constituents. Many samples have experienced a variable extent of low-pressure crystal fractionation of olivine and clinopyroxene as indicated by the range in $\mathrm{MgO}$. For example, CLSC glasses range from $9.54 \%$ to $2.0 \% \mathrm{MgO}$ and ELSC glasses range from $8.02 \%$ to $6.45 \% \mathrm{MgO}$. Although olivine-plagioclase-(clinopyroxene) basalts predominate on the ridge systems, some highly fractionated rocks and glasses are also present. For example, in the vicinity of the CLSC propagating tip there are highly fractionated samples best termed $\mathrm{Fe}-\mathrm{Ti}$ basalts (e.g., $1.9 \%-2.4 \% \mathrm{TiO}_{2}$ and $13.5 \%-16.1 \% \mathrm{FeO}^{*}$ ). One CLSC sample is an "oceanic andesite."

The crystallization sequence on both ridges appears to have been (chrome-spinel)+olivine-plagioclase-clinopyroxene-oxides or sulfides; this is the typical MORB sequence (e.g., Bryan et al., 1981). Nearly all of the samples have both olivine and plagioclase microphenocrysts in glass indicating compositions lying on or near a two phase plus liquid boundary. Clinopyroxene is present as a third microphenocryst phase in most samples or with plagioclase alone in some of the more highly fractionated samples. Olivine forms euhedral phenocrysts, highly skeletal and euhedral microphenocrysts (in glass), and is a groundmass constituent in most samples. Less common are irregular grains, with high $\mathrm{Mg}$ content (e.g., $\mathrm{Fo}_{89}$ ) that probably are xenocrysts. The least fractionated samples (e.g., $\mathrm{MgO}>6.8 \%$ ) have olivine ranging from $\mathrm{Fo}_{81.7}$ to $\mathrm{Fo}_{87.7}$, whereas the more fractionated samples have olivine as evolved as $\mathrm{Fo}_{76}$. Xenocrysts of both plagioclase and olivine are present in some samples; $\mathrm{An}_{83}$ and $\mathrm{Fo}_{89}$ core compositions were found. In both cases the xenocrysts show resorbed/corroded grain margins and rim compositions in apparent equilibrium with the host melt.

Chrome spinel is a minor constituent, but is of interest in reflecting early melt chemistry. The $\mathrm{Cr} \#=[\mathrm{Cr} /(\mathrm{Cr}+\mathrm{Al})]$ ranges from 0.3 to 0.5 , and $\mathrm{Mg}$ \# ranges from 0.70 to 0.76 . These values are typical of MORB or abyssal chrome spinel (Dick and Bullen, 1984; Hawkins and Melchior, 1985; Allan et al., 1988) and distinct from "arc" chrome spinels that have low $\mathrm{Mg} \#$ and high Cr\#. The differences between MORB and arc, or SSZ, chrome spinels are usually attributed to differences in the extent of melting of the source, previous depletion of the source, and the $\mathrm{fO}_{2}$ with $\mathrm{SSZ}$ spinels reflecting higher oxygen fugacity.

Plagioclase ranges from $\mathrm{An}_{64}$ to $\mathrm{An}_{89}$ in least fractionated samples, and from $\mathrm{An}_{54}$ to $\mathrm{An}_{77}$ in more evolved samples. Zoning is typically oscillatory and normal. The Or component is very low, typically 

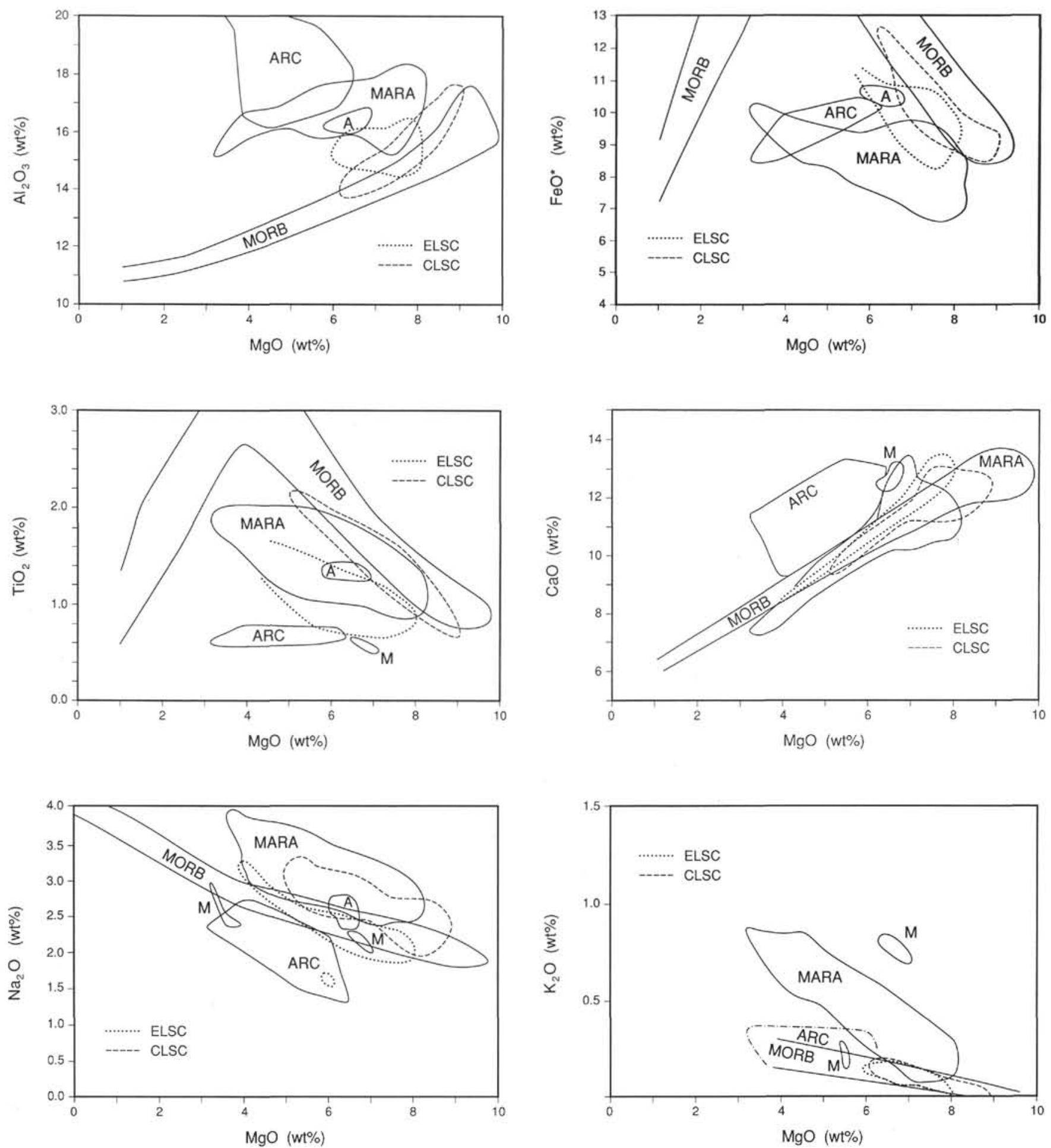

Figure 3. Major element data plotted vs. MgO showing fields for MORB, for arc systems, for the Mariana Trough (MARA), and the Lau Basin (CLSC and ELSC). Outliers are A (Arc) and M (MARA). MORB and ARC fields after Hochstaedter, Gill, Kusakabe, et al. (1990). MARA data from Hawkins et al. (1990). Lau Basin data from Hawkins and Melchior (1985) and Hawkins (1988, 1989).

$0.1 \%$, and never exceeds $0.4 \%$ even in the most highly fractionated Fe-Ti basalts.

Clinopyroxene is mainly endiopside or augite; it forms phenocrysts in glass and holocrystalline material, and is a constituent of the groundmass. Compositions range from $\mathrm{Wo}_{36.3}$ to $\mathrm{Wo}_{41.7}$ and from $\mathrm{En}_{45}$ to $\mathrm{En}_{52.5}$. The clinopyroxene is characterized by low $\mathrm{Al}_{2} \mathrm{O}_{3}$
$(2 \%-5 \%), \mathrm{TiO}_{2}(<1.5 \%)$, and $\mathrm{Cr}_{2} \mathrm{O}_{3}(<1 \%)$, all of which suggest that it formed at relatively low pressure (e.g., $<3 \mathrm{~kb}$ ). Opaque minerals are mainly Ti-magnetite and magnetite that form bladed, skeletal or cruciform microphenocrysts. The Ti-magnetite is relatively abundant (e.g., $1 \%-2 \%$ ) in the Fe-Ti basalt, whereas magnetite is the oxide phase in the ocean andesite samples. 


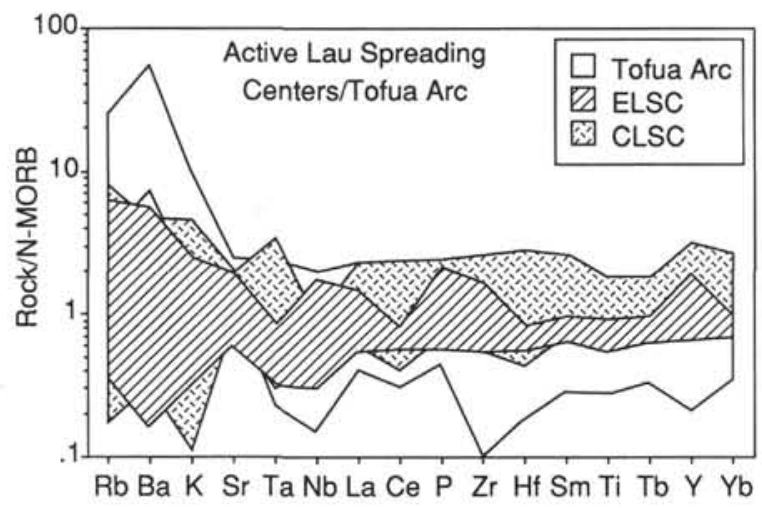

Figure 4. Trace element data for CLSC, ELSC, and Tofua Arc normalized to N-MORB. Normalizing values from Sun and McDonough (1989). Sources of data for CLSC and ELSC are Hawkins $(1976,1988,1989)$ and Hawkins and Melchior (1985); Tofua Arc data are from Ewart and Hawkesworth (1987).

Samples from the relay zone are mineralogically similar to the axial ridge samples except for some samples having orthopyroxene $\left(\mathrm{Wo}_{4}-\right.$ $\left.\mathrm{Wo}_{5}, \mathrm{En}_{76}-\mathrm{En}_{78}\right)$ and low-calcium augite $\left(\mathrm{Wo}_{23}-\mathrm{Wo}_{30}, \mathrm{En}_{53}-\mathrm{En}_{60}\right)$.

\section{PETROLOGY AND GEOCHEMISTRY OF THE BACKARC SITES}

\section{Introduction}

Magmatism in ocean basins mainly occurs at mid-ocean ridges and at convergent plate margins where two fundamentally different mantle regions give rise to partial melts each having distinctive chemical signatures. These distinctive magma systems reflect differences in their sources, extent of melting, and depths of separation of melts and their residue. Basalts from mid-ocean ridges, except for those thought to be influenced by the distinctive magmas from melting anomalies (i.e., mantle plumes) or those formed at propagating rift tips (Sinton et al., 1983), exhibit a fairly restricted range in chemistry and isotopic composition. These serve to define "normal" or N-MORB (e.g., Bryan et al., 1976; Melson et al., 1976; Viereck et al., 1989). Magmatism at convergent oceanic plate margins develops a range of magma types dominated by arc-tholeiitic basalt and andesite (e.g., Gill, 1970).

The SSZ mantle at convergent oceanic plate margins must have experienced a complex history that includes depletion by previous melting events and variable reenrichment by fluids and melts derived from the subducted lithosphere (e.g., Pearce et al., 1984; Tatsumi et al., 1986; Tatsumi, 1989). Mantle counterflow into the potential void formed above the subducted lithosphere as the result of trench rollback may be an extremely important contribution that adds further complexity to the SSZ mantle source (Sleep and Toksoz, 1971; Toksoz and Bird, 1978; Hawkins et al., 1984). Backarc basins are situated above SSZ mantle, therefore, it would not be surprising to find that arc-like rocks are common. As discussed in a previous section, we find instead that most backarc basins have heterogeneous crust that varies from MORB to arc-like. There are abundant data showing that the most widespread crustal rocks in backarc basins have MORB-like compositions and, by inference, are derived from MORB-source mantle. Nonetheless, many backarc basins have ridge segments, and seamounts, with rocks carrying the geochemical signatures of arc magmas as well as having larger areas of basalt transitional in composition between arc and MORB. Compositional heterogeneity, and deviation from MORB chemistry, both between and within backarc basins, was discussed above. For example, Mariana Trough basalts have major element differences that are accompanied by differences in the HFSE (Hawkins and Melchior, 1985; Hawkins et al., 1990), LILE (e.g., Hart et al., 1972; Wood et al., 1981), and volatiles (Garcia et al., 1979) all of which give many of the Mariana Trough basalts compositions transitional to arc chemistry. Hawkins and Melchior (1985) showed that basalts, like the Mariana Trough basalts, are found in parts of the Lau Basin. In some backarc basins we find rocks with arc chemistry (e.g., Mariana Trough [Hawkins et al., 1990] and parts of the Lau Basin [Parson, Hawkins, Allan, et al., 1992; Ewart et al., this volume]).

The heterogeneity of Lau Basin crust was known before Leg 135, but the drill-core data adds to our understanding of this heterogeneity by giving us samples from the previously inaccessible, older, sediment-covered parts of the western basin. We see both regional compositional heterogeneity, as demonstrated by variations between the drill sites, and intrasite variations as seen by differences between petrographic units.

\section{Major Element Chemistry}

Our new data for 115 glasses and 60 aphyric to sparsely phyric rocks, plus shipboard data, are in Appendixes A and B. Summaries of representative data are in Tables 2 and 3 , and trace element data are in Table 4. The glass data all are from fresh, clear, tan to brown sideromelane showing no apparent signs of alteration. The microprobe analyses of glass are from quenched margins of pillows or flows and, although all are vitrophyric and locally show spots of darkened glass (spherulitic structures), the spots analyzed were of pure glass. The analytic sums are all nearly $98.5 \%$ or higher. The difference from $100 \%$ is assumed to reflect the presence of water and $\mathrm{CO}_{2}$. The iron is expressed as $\mathrm{FeO}^{*}$, which introduces a small error in the sum, because we know that the ratio $\mathrm{Fe}^{3+} / \mathrm{Fe}^{2+}$ is on the order of $0.15-0.25$, as determined by direct measurement of $\mathrm{FeO}$ by titration (Nilsson, this volume).

The bulk-rock XRF data are from aphyric to sparsely phyric samples selected to represent the lower, middle, and upper parts of the petrographic units. The INAA data (Table 4) for selected rock samples provide a representative set of REE and other trace element data. The glass data are, in most cases, similar to bulk-rock data for nearby or contiguous samples of aphyric rock. Thus, the aphyric rock data are a close approximation to liquid compositions. However, moderately phyric samples with more than $9 \% \mathrm{MgO}$, or $17 \% \mathrm{Al}_{2} \mathrm{O}_{3}$, probably reflect the presence of phenocrysts. Much of the mesostasis of the rocks shows varying amounts of alteration. It is likely that the $\mathrm{K}, \mathrm{Na}$, $\mathrm{Rb}, \mathrm{Ba}$, and possibly $\mathrm{Sr}$ of some of these samples may be suspect.

Silica and the oxides of $\mathrm{Al}, \mathrm{Mg}, \mathrm{Ca}, \mathrm{Fe}$, and $\mathrm{Ti}$ are major variables in the drill-core data. Considering all of the backarc sites, the $\mathrm{SiO}_{2}$ content varies from $49.20 \%$ to $56.15 \%$, covarying negatively with $\mathrm{MgO}$, which ranges from $3.2 \%$ to $15.2 \%$. Other major and minor elements covary in a predictable fashion for magma evolution controlled largely by low-pressure crystal fractionation (i.e., olivine, plagioclase, clinopyroxene, Fe-Ti oxides). Plagioclase occurs as a phenocryst or microphenocryst, together with olivine, clinopyroxene, or both, in all of the samples studied. There is no petrographic evidence to suggest that plagioclase crystallization was suppressed in any of our samples, including liquid compositions that range as high as $8 \% \mathrm{MgO}$.

There are significant compositional differences between sites, between the units at each site, and within the units. Much of the intrasite variation may be explained by low-pressure fractional crystallization, but the intersite variability must be the result of source differences, different extent of melting, or both.

The drill-site data are presented in Figure 5 and are compared with the data fields for the Mariana Trough, CLSC, and ELSC in Figure 6. The drill sites may be divided into those with rocks broadly similar to the CLSC and ELSC (Sites 834-836) and those more like the Mariana Trough or modern Tofua Arc (Sites 837-839). We will consider first the glasses from Sites 834 through 836 . Site 834 shows more variability than any of the other sites, but this may be because the hole was drilled to a greater depth than any of the others and we have more data. $\mathrm{SiO}_{2}$ varies from $49.8 \%$ to $56.15 \%$ correlating positively with oxides of $\mathrm{Ti}, \mathrm{Fe}, \mathrm{Mn}, \mathrm{K}$, and $\mathrm{P}$. There is a negative 

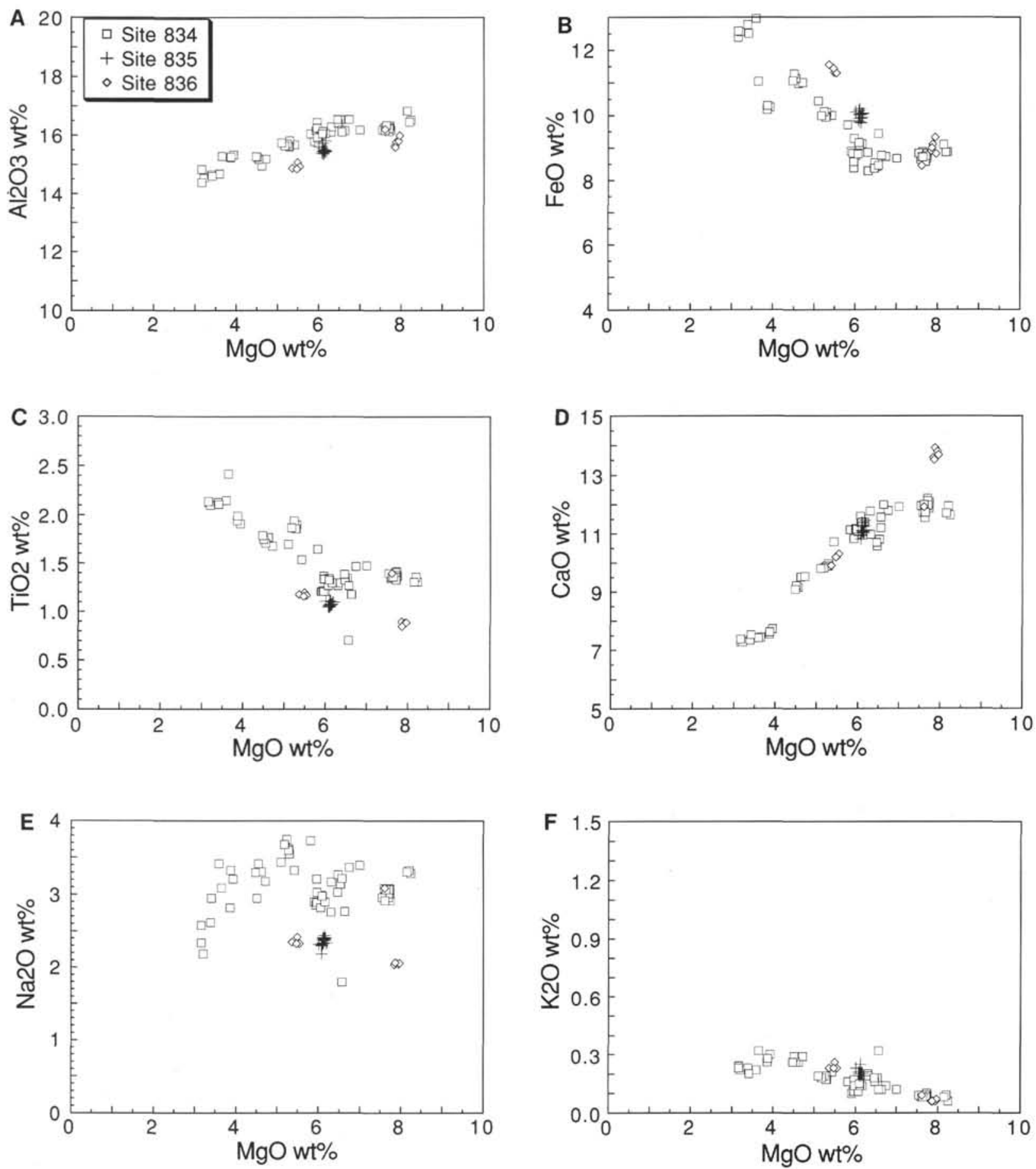

Figure 5. Major element data for Lau Basin glasses plotted vs. MgO. Data for Sites 834 and 835 appear in Figures $5 \mathrm{~A}-5 \mathrm{~F}$ and for Sites 838 and 839 in Figures 5G-5L.

correlation with $\mathrm{Al}, \mathrm{Ca}$, and $\mathrm{Mg}$. Similar covariation, over a lesser range, is seen at the other drill sites. Data for Site 835 essentially define one point but this lies on, or close to, variation trends defined by data from the other sites. The extensive data for Site 834 do not show any uniform compositional trends with depth. The least fractionated samples were found near the middle of the depth range cored with some of the most fractionated samples being near the bottom. We have no idea of the composition or depth of the first magmas erupted. The range in glass composition is shown in the CMAS system as projected from plagioclase on to the OL-DI-SIL diagram (Fig. 7).
The data define an evolutionary trend following the experimentally determined low pressure cotectic.

Rock and glass chemistry ranges from olivine-normative tholeiite to $\mathrm{Fe}-\mathrm{Ti}$ basalt with extreme compositions approaching andesite. Few of the rocks or glasses at Sites 834,835 , and 836 have more than $7.5 \%$ $\mathrm{MgO}$ and none has more than $8.2 \%$. Thus all have experienced some level of fractionation from more primitive parental melts. For example, the Mg\# varies from 64.8 to 34.0 for Site 834 glasses and from 69.7 to 36.0 for the rocks. The rock sample with $\mathrm{Mg \#}$ of 69.7 is a moderately phyric plagioclase-olivine-clinopyroxene basalt. Thus, 

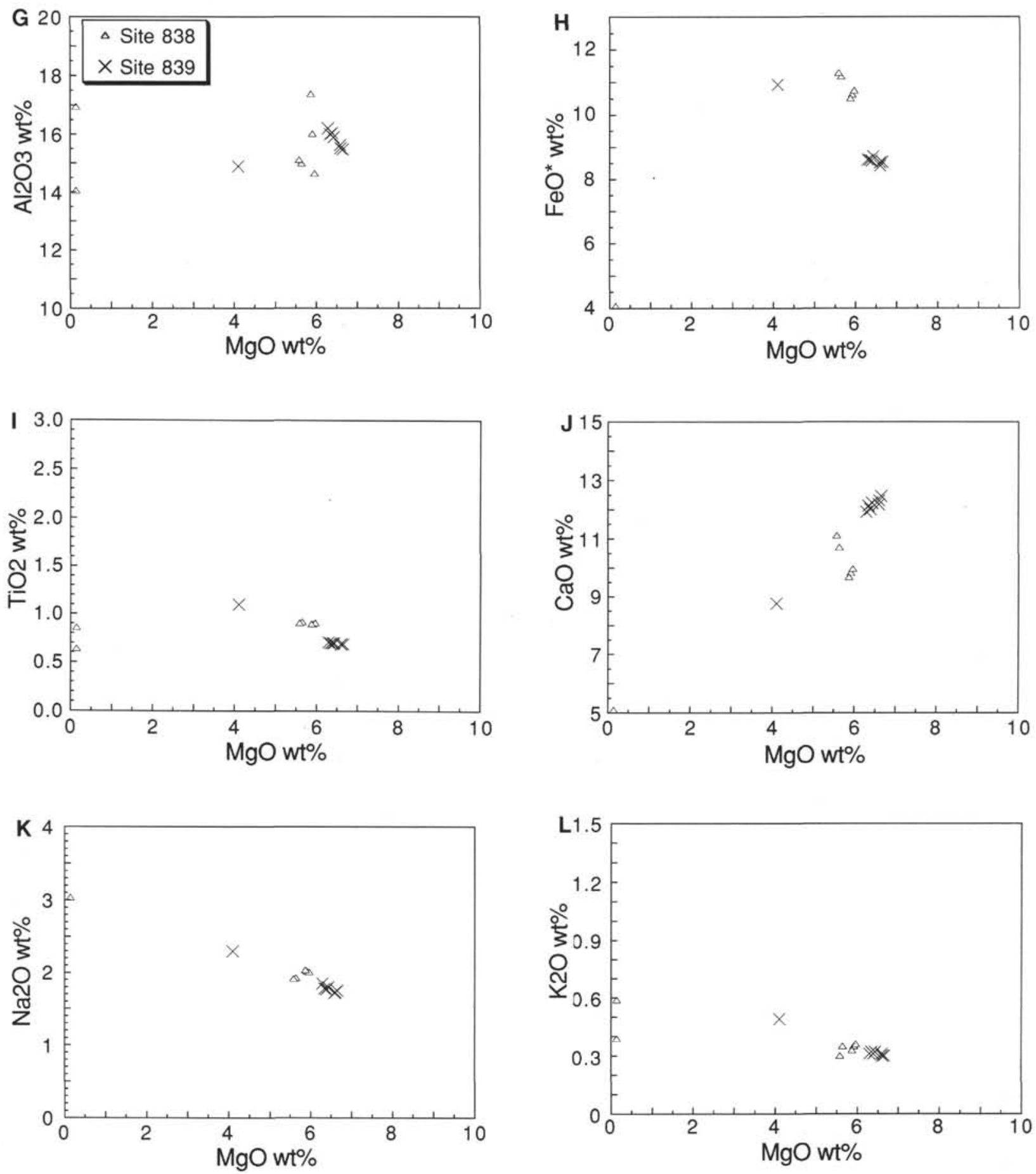

Figure 5 (continued).

the slightly higher $\mathrm{MgO}$ content $(8.99 \%)$ can be explained by the presence of phenocrystal olivine. Site 835 sampled a single petrographic unit in which there is little compositional variation. This unit must have been derived from a more $\mathrm{Mg}$-rich parental magma as the glass samples range from $6.0 \%$ to $6.2 \% \mathrm{MgO}$. The data lie in a small cluster near the olivine-clinopyroxene cotectic in Figure 7. Site 836 glasses are more variable; $\mathrm{MgO}$ ranges from $5.4 \%$ to $8.0 \%$. Glass data lie in two small clusters on the olivine-clinopyroxene cotectic (Fig. 7) suggesting fractional crystallization of a common parental magma. In the following discussion of Sites 834,835 , and 836 , we will use

largely the data for glasses with more than $6 \% \mathrm{MgO}$ to avoid effects caused by crystal accumulation or fractionation or to alteration. We have made the point that Sites 834,835 , and 836 are MORB-like if not true MORB. Let us consider the data to support this. Glasses from the Lau Basin neovolcanic zones are intermediate between MORB and the Mariana Trough, but unlike arcs, for $\mathrm{Al}_{2} \mathrm{O}_{3}, \mathrm{FeO}^{*}$, and $\mathrm{TiO}_{2}$. They are identical to MORB for $\mathrm{CaO}$ and $\mathrm{K}_{2} \mathrm{O}$, whereas $\mathrm{Na}_{2} \mathrm{O}$ varies from MORB to Mariana values (Figs. 3A-3F). Drill-core data for oxides vs. $\mathrm{MgO}$ are in Figures $5 \mathrm{~A}-5 \mathrm{~F}$, and the fields are compared to the axial ridge data in Figures $6 \mathrm{~A}-6 \mathrm{~F}$. Site 834 overlaps with both the 

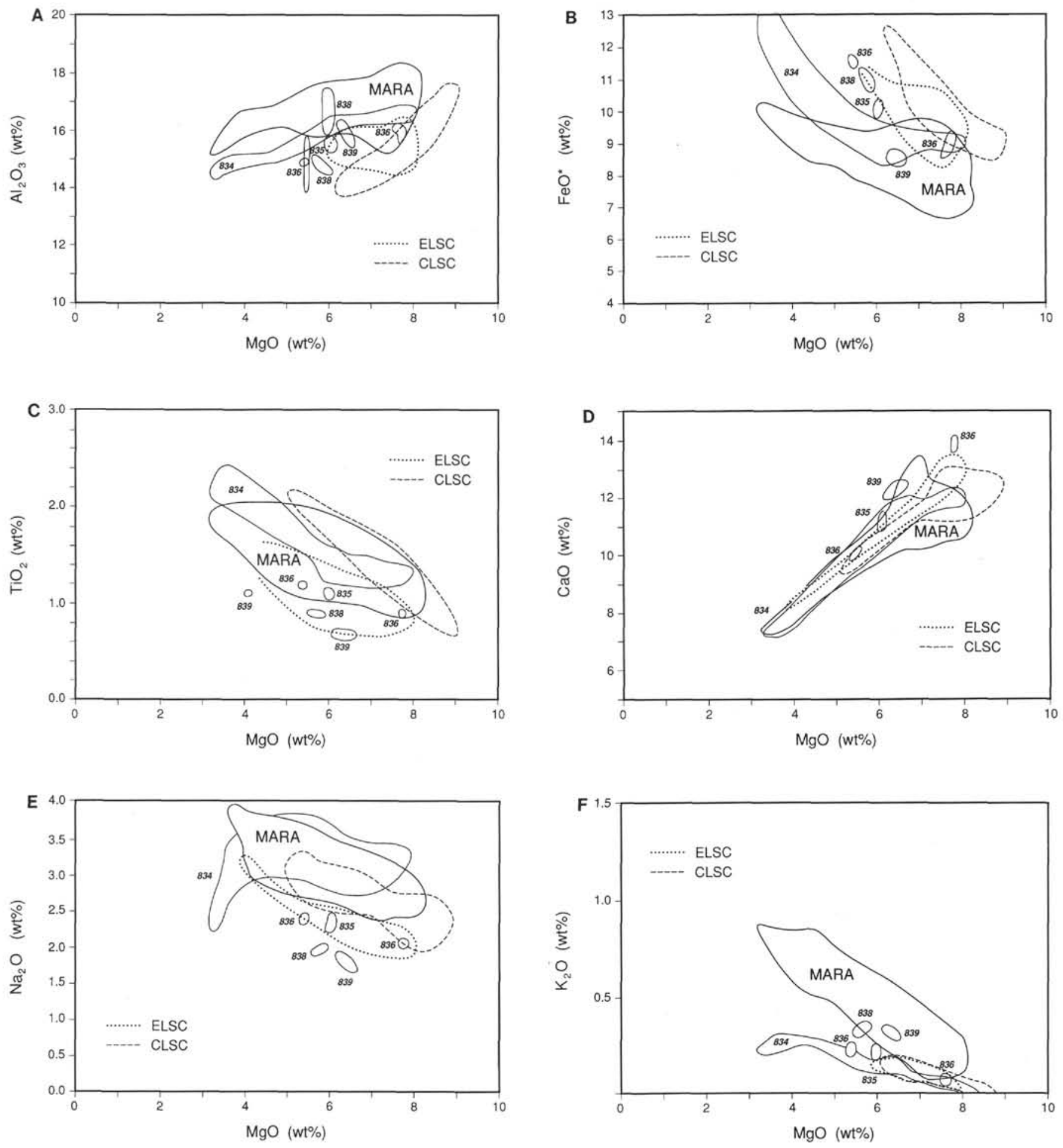

Figure 6. Major element data plotted vs. MgO for drill sites and for Mariana Trough axial ridge (MARA), ELSC, and CLSC. All data are for glasses. Fractionation trends in Figure $6 \mathrm{G}$ are $\mathrm{A}=30 \%$ fractionation of olivine and plagioclase $(1: 2) ; \mathrm{B}=30 \%$ fractionation of olivine and plagioclase $(1: 1)$; and $\mathrm{C}=$ fractionation of plagioclase and clinopyroxene (1:1). Fractionation trend in Figure $6 \mathrm{H}$ is for mixture of olivine and plagioclase.

ELSC and CLSC in $\mathrm{FeO}^{*}$, $\mathrm{TiO}_{2}, \mathrm{CaO}$, and $\mathrm{K}_{2} \mathrm{O}$ and with the Mariana Trough in $\mathrm{Al}_{2} \mathrm{O}_{3}$ and $\mathrm{Na}_{2} \mathrm{O}$. Site 835 resembles the ELSC. Site 836 is closely similar to the ELSC and like MORB in FeO*, $\mathrm{CaO}$, and $\mathrm{K}_{2} \mathrm{O}$.

Note that although the Lau Basin samples are displaced toward the arc field for both $\mathrm{Na}_{2} \mathrm{O}$ and $\mathrm{Al}_{2} \mathrm{O}_{3}$, the $\mathrm{TiO}_{2}$ values are not as depleted as those of the arcs and define MORB-like slopes. The Lau
Basin neovolcanic zone (ELSC and CLSC) glasses, and samples from Site 835 and 836, are similar on these plots, whereas Site 834 samples overlap with Mariana Trough glasses. The trends for $\mathrm{Al}_{2} \mathrm{O}_{3}$ vs. $\mathrm{MgO}$ (Figs. 5A and 6A) are instructive both for comparing the data to other petrologic series and in evaluating the timing of appearance of plagioclase as a liquidus phase. There is a monotonic steep slope for CLSC 

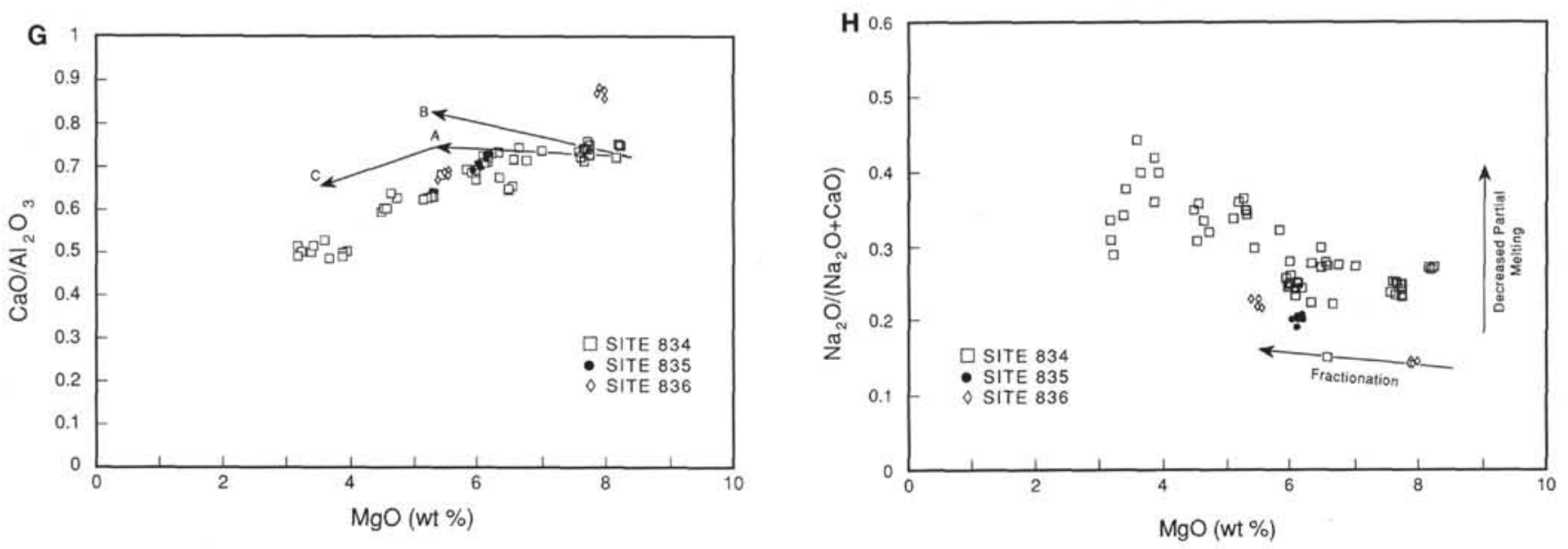

Figure 6 (continued).
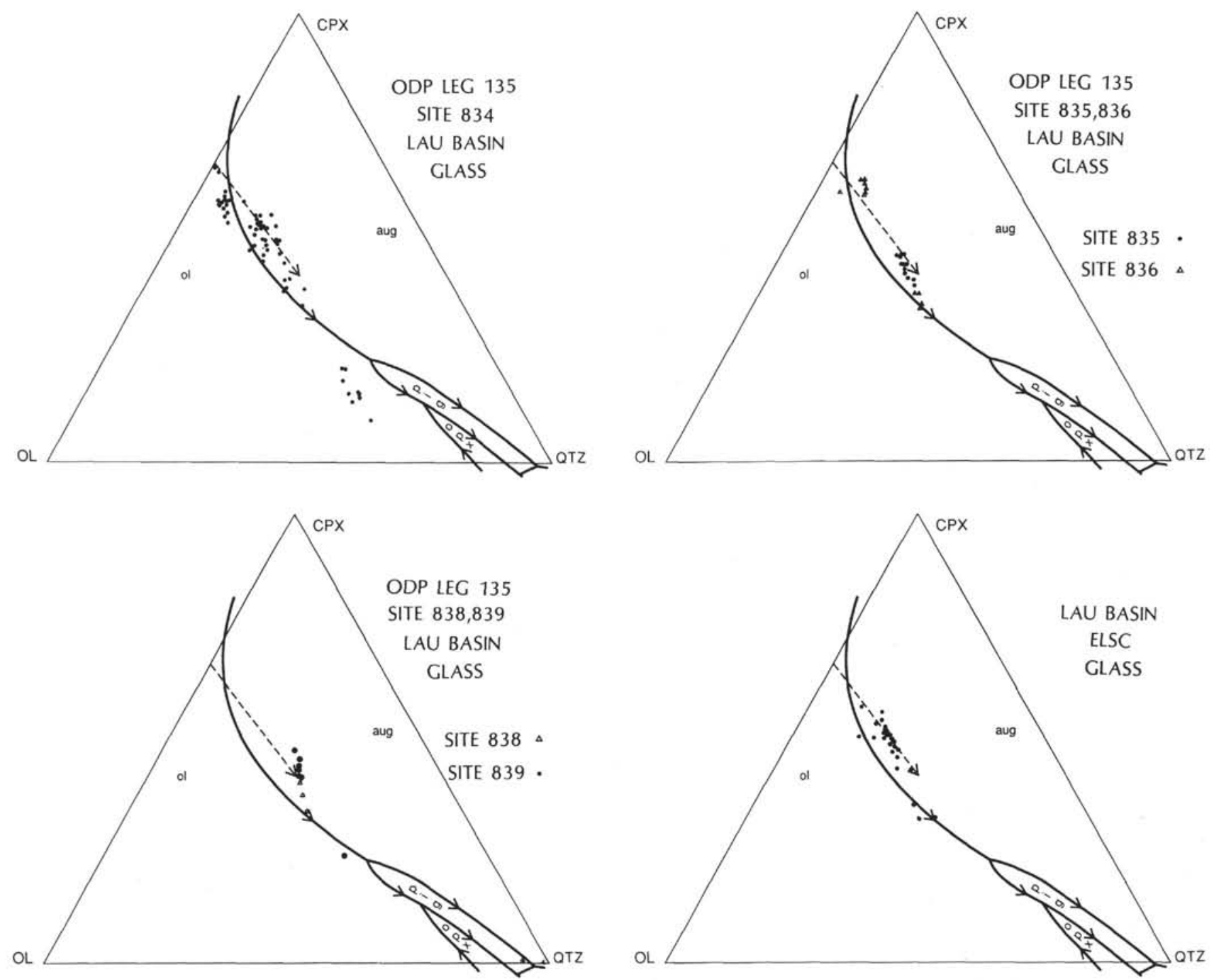

Figure 7. Glass data plotted on CMAS diagram as projected from plagioclase. $\mathrm{OL}=$ olivine, $\mathrm{CPX}=$ "diopside," and QTZ = "silica." Curved solid lines are the projected positions of the 1-atm, dry, multiply-saturated cotectics. The dashed lines are schematic locations of the boundaries at unspecified increased pressure. After Grove et al. (1982). 
and Site 836 samples that follows a MORB pattern of decreasing $\mathrm{Al}_{2} \mathrm{O}_{3}$ with decreasing $\mathrm{MgO}$. Site 834 defines a similar, but less steep, slope. Thus, plagioclase must have been an early liquidus phase. Site 835 samples lie on this trend but the data are too few to establish a slope. Site 834 samples show a minor change in slope at about $5.5 \%-6.0 \% \mathrm{MgO}$, which may reflect the appearance of clinopyroxene on the liquidus. The lesser slope at higher $\mathrm{MgO}$ suggests that early plagioclase crystallization may have been inhibited, but not suppressed, in more mafic lavas. Petrographic study shows that plagioclase was a liquidus, or near-liquidus, phase because it is found together with olivine in all Site 834 samples including glasses having up to $8 \% \mathrm{MgO}$.

$\mathrm{FeO}^{*}$ and $\mathrm{TiO}_{2}$ are correlated positively with $\mathrm{MgO}$ (Figs. 5B-5C) as is true for MORB, the axial ridges, and the Mariana Trough. The drill-site data parallel MORB fields but, as noted previously, they are offset to slightly lower values. The MORB field is controlled by fractionation of olivine, plagioclase, and clinopyroxene (e.g., Bryan, 1979), in which, initially, $\mathrm{TiO}_{2}$ and $\mathrm{FeO}$ increase monotonically with fractionation; nearly all of the Leg 135 glasses lie in or close to this field except for those that are most evolved. Data for other Lau Basin glasses show similar relations. The CLSC field is close to MORB, but the fields for the Mariana Trough, Sites 834 through 836, and ELSC are successively displaced toward lower (arc-like) $\mathrm{TiO}_{2}$. For $\mathrm{TiO}_{2}$ as well as $\mathrm{FeO}^{*}$, this may reflect differences in oxygen fugacity in the source. In contrast, modern Tofua Arc data show a nearly flat trajectory at low $\mathrm{TiO}_{2}$ (Ewart and Hawkesworth, 1987). This pattern is typical of other immature oceanic arcs and must reflect either a source depleted in $\mathrm{Ti}$, preferential removal of $\mathrm{Fe}$-Ti oxides, or both.

$\mathrm{CaO}$ correlates well with $\mathrm{MgO}$ (Fig. 5D), and for all backarc data the trends coincide with the MORB field. The ratio $\mathrm{CaO} / \mathrm{Al}_{2} \mathrm{O}_{3}$ (Fig. $6 \mathrm{G})$ gives insight to the relative importance of plagioclase $(\mathrm{CaO} /$ $\left.\mathrm{Al}_{2} \mathrm{O}_{3}=0.45\right)$ or clinopyroxene $\left(\mathrm{CaO} / \mathrm{Al}_{2} \mathrm{O}_{3}>0.7\right)$ in petrogenesis. The MORB crystallization sequence of olivine-plagioclase-clinopyroxene contrasts with the arc sequence of olivine-clinopyroxene-(orthopyroxene)-plagioclase. Typical MORB with $>7.5 \% \mathrm{MgO}$ have $\mathrm{CaO} / \mathrm{Al}_{2} \mathrm{O}_{3}>0.75$ (Viereck et al., 1989), indicating the delayed onset of clinopyroxene crystallization in MORB magmas. The least evolved glasses at Sites 834 through $836(\mathrm{MgO}>7.5 \%)$ all have high $\mathrm{CaO} /$ $\mathrm{Al}_{2} \mathrm{O}_{3}(0.65-0.87)$, indicating that fractionation of clinopyroxene was not an important petrogenetic control early in melt evolution. Plagioclase crystallization would help keep the ratio high, or increase it, whereas CPX crystallization should cause a rapid decrease. The ratio behaves different with decreasing $\mathrm{MgO}$ at each site, as shown in Figure 6G. For example, at Site 836 there are several samples with about $8 \%$ $\mathrm{MgO}$ and $\mathrm{CaO} / \mathrm{Al}_{2} \mathrm{O}_{3}=0.85$. At $7.6 \% \mathrm{MgO}$, the ratio drops to 0.74 and decreases to less than 0.7 . Presumably, this reflects the onset of clinopyroxene as a liquidus phase. At Site 835 , the ratio is constant at about 0.7 for all of the samples (MgO range is $6.0 \%-6.2 \%$ ). At Site 834, the behavior is more complex. The ratio is about 0.75 for $\mathrm{MgO}$ higher than $7.7 \%$ and then decreases uniformly as $\mathrm{MgO}$ decreases. The theoretical trend for fractionation of a mixture of olivine and plagioclase parallels the trend of the data and supports the inference that plagioclase crystallization was important in all of the glasses (liquids) we sampled at these sites. If plagioclase crystallization had been suppressed, the early onset of clinopyroxene would have caused a rapid drop in $\mathrm{CaO} / \mathrm{Al}_{2} \mathrm{O}_{3}$.

Abundances of $\mathrm{Na}$ and $\mathrm{K}$ show interesting differences. As noted by Fryer et al. (1981), Mariana Trough samples have distinctively high $\mathrm{Na}$ abundances; as a group, Lau Basin ELSC and CLSC samples (Fig. 3) are intermediate between the MORB and Mariana Trough samples. $\mathrm{Na}_{2} \mathrm{O}$ at Site 834 (Fig. 6E) resembles Mariana Trough data, and both are distinctly higher than Lau Basin neovolcanic zones or Sites 835 and 836 . Sites 835 and 836 overlap the field for ELSC. The plot of the ratio $\mathrm{Na}_{2} \mathrm{O} /\left(\mathrm{Na}_{2} \mathrm{O}+\mathrm{CaO}\right)$ vs. $\mathrm{MgO}$ (Fig. $\left.6 \mathrm{H}\right)$ gives information about extent of melting and fractionation effects. Considering the glasses with more than $6 \% \mathrm{MgO}$, and assuming that the sources had similar sodium contents, the data suggest that Site 834 melts represent a lower extent of melting than at Site 835, and Site 836 melts were derived by the highest extent of melting. Within the Site 834 samples a range may be recognized. The highest ratios are from Unit 7, which is the most primitive, and probably the most voluminous, flow unit. Unit 2 may represent the most extensively melted magma batch at Site 834, but it is a lower melt fraction than that from Site 835 . Evolution of the Sites 834 and 836 magmas by fractional crystallization is indicated as well.

Variations in K (Fig. 6F) are much more coherent. All of the Lau Basin drill-site and spreading center samples, except Site 839, lie in the field for MORB. The $\mathrm{K}_{2} \mathrm{O}$ content of the glasses varies with $\mathrm{MgO}$; the least fractionated glasses have $<0.2 \% \mathrm{~K}_{2} \mathrm{O}$. This MORB-like $\mathrm{K}$ concentration is about a factor of 2 lower than that for typical transitional basalts of the Mariana Trough, which plot in a distinctly higher $\mathrm{K}$ field that is displaced toward that for low- to medium- $\mathrm{K}$ arc tholeiites (Gill, 1970).

Samples from Sites 837 and 838 show an arc-like affinity, based on the combined glass and bulk-rock data, although none have compositions that are truly like arc lavas. Site 837 rocks include basalt and basaltic andesite with both clinopyroxene and orthopyroxene. No glass was recovered at Site 837, but the bulk-rock silica content ranges from $54 \%$ to $56 \%$, and $\mathrm{MgO}$ from $3 \%$ to $3.4 \%$; this range gives the samples a marked similarity to Valu Fa Ridge samples (Jenner et al., 1987; Vallier et al., 1991) and to island-arc tholeiites in general. Aphyric rock data from Site 837 are not shown on Figure 6, but they would lie in the field for Mariana Trough samples, except for Fe and $\mathrm{Al}$, which are more like ELSC data. Collectively, the data suggest that Site 837 sampled crust transitional between MORB and arc lavas, and is thus similar to the "Mariana Trough-type basalts" that Hawkins and Melchior (1985) described for the western Lau Basin.

Site 838 samples are clasts of aphyric to sparsely phyric clinopyroxene-plagioclase basalt from a gravel bed. Glasses, from chilled margins, range from $52 \%$ to $69 \%$ silica. Fragments with up to $73 \%$ silica, also found in the cores, may be pumice from other sources. Glass data for Site 838 (Fig. 6) resemble ELSC glasses for most of the major elements; they are fractionated melts as seen on Figure 7. However, they have arc-like $\mathrm{Na}$ and several data plot in the Mariana Trough field for $\mathrm{Al}$. They resemble some of the samples from the relay zone between the CLSC and ELSC systems (Table 5) and some dredged samples from areas of older crust that Hawkins and Melchior (1985) referred to as "Mariana Trough Basalt" type crust (Table 5).

Some of the Site 839 samples are similar to those at Sites 837 and 838 , but others are even more arc-like and are very close in composition to rocks from the modern Tofua Arc and from the Valu Fa Ridge (Vallier et al., 1991). Site 839 samples include two-pyroxene basalts and basaltic andesites. Their silica content ranges from $50 \%$ to $55 \%$ and $\mathrm{MgO}$ ranges from $4.4 \%$ to $15 \%$. Site 839 bulk-rock samples with $\mathrm{MgO}$ contents greater than $9 \%$ are not liquid compositions as they have abundant phenocrysts of olivine and clinopyroxene.

Variation diagrams for major elements plotted relative to $\mathrm{MgO}$ (Figs. 5G-5L) show that $\mathrm{FeO}^{\circ}, \mathrm{CaO}$, and $\mathrm{K}_{2} \mathrm{O}$ are like Mariana Trough glasses, whereas $\mathrm{Al}_{2} \mathrm{O}_{3}$ overlaps the Mariana Trough and ELSC fields. $\mathrm{TiO}_{2}$ is low and close to the arc field; $\mathrm{Na}_{2} \mathrm{O}$ is MORBlike but also resembles some arc values. A fractionated sample from this site has $\mathrm{FeO}^{*}$ and $\mathrm{Al}_{2} \mathrm{O}_{3}$ like fractionated rocks from Site 834; other elements have low abundances and are close to arc compositions. The $\mathrm{Al}_{2} \mathrm{O}_{3}$ content of Site 838 and 839 glasses (Fig. 6A) is less than $16 \%$ and among the lowest values of all of the backarc glasses. Site 839 glasses have the lowest $\mathrm{TiO}_{2} / \mathrm{MgO}$ of all the Lau Basin samples but $\mathrm{TiO}_{2}$ is not as low as in samples from the nearby Tofua Arc (Ewart et al., 1977).

Collectively, the data show that the sources for the Site 837,838 , and 839 parental melts were different from the sources for melts erupted at Sites $834,835,836$. The major element data show many similarities to Mariana Trough and ELSC samples, except for having even more of an SSZ signature. They have lower $\mathrm{FeO}, \mathrm{TiO}_{2}$, and $\mathrm{Na}_{2} \mathrm{O}$ but higher $\mathrm{Al}_{2} \mathrm{O}_{3}$ and $\mathrm{K}_{2} \mathrm{O}$. They are even more depleted, more 

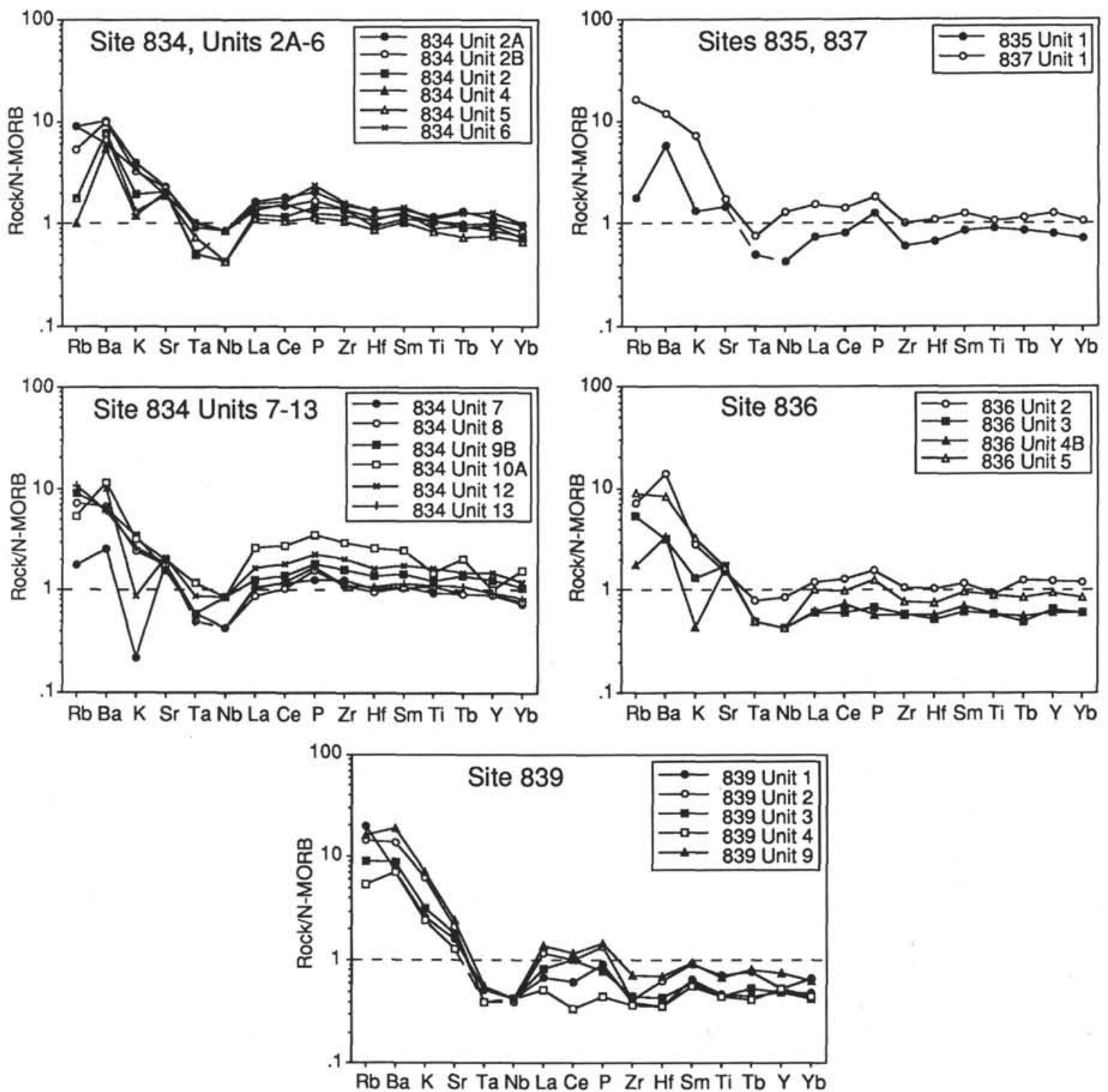

Figure 8. Trace and minor element data for Sites 834 through 839 normalized to N-MORB. Normalizing values after Sun and McDonough (1989).

arc-like, than either of these two ridge systems that also have SSZ signatures (Site 837 and 838 samples are fractionated and parental melts can only be estimated). If Site 839 samples had been collected in the modern Tofua Arc, they would be considered part of the arc-magma series. However, even though they have other arc-like signatures, they lack the high $\mathrm{Al}$ postulated for melts from a hydrous SSZ source-perhaps it was relatively anhydrous. These samples pose an interesting problem because they are from rafts of arc-like crust engulfed in a sea of MORB-like basalt (i.e., ELSC crust). Their presence is not unique in the Lau Basin because similar rocks are found on the Valu Fa Ridge and the Mangatolu Triple Junction. The ridge and the triple junction both are sites of active magma upwelling on rifts forming in older crust. A similar tectonic process may have been important in the generation of these samples.

\section{Trace Element Chemistry}

Trace element data were collected for the aphyric bulk-rock samples. The complete data are in Appendix B and representative data for each unit are summarized in Table 3; REE data for aphyric rocks are in Table 4. The data are shown normalized to N-MORB in Figure 8. Comparable data for the Tofua Arc, ELSC, and CLSC are given in Figure 3 . The backarc basin drill-site samples are relatively enriched in the LILE and depleted in the HFSE when normalized to N-MORB. As discussed subsequently, much of the range for each site is easily explained as the result of low-pressure crystal fractionation, whereas intersite variations must reflect differences in sources for parental melts. Sites 834,835 , and 836 define a fairly narrow band that resembles MORB for those HFSE that plot to the right of $\mathrm{Nb}$. However, many of the least fractionated samples are somewhat depleted in these elements relative to $\mathrm{N}-\mathrm{MORB}$. $\mathrm{Ta}$ and $\mathrm{Nb}$ are clearly lower for all samples, whereas the LILE, $\mathrm{Ba}, \mathrm{Rb}$, and $\mathrm{Sr}$ are higher; $\mathrm{K}$ is variable. The patterns closely parallel those for the ELSC and CLSC. Some of the enrichment in alkalis relative to HFSE is likely caused by the pervasive low-grade alteration that has affected nearly all of the rocks. Alkali and alkaline earth data for glasses from the same cores are lower than for the rocks (Hergt and Nilsson, this volume). The enrichments/depletions relative to N-MORB follow those for SSZ magmas (e.g., arc-magma systems; Gill, 1970; Perfit et al., 1980; Pearce et al., 1984), but none are as extreme as typical arc patterns. We infer that the 

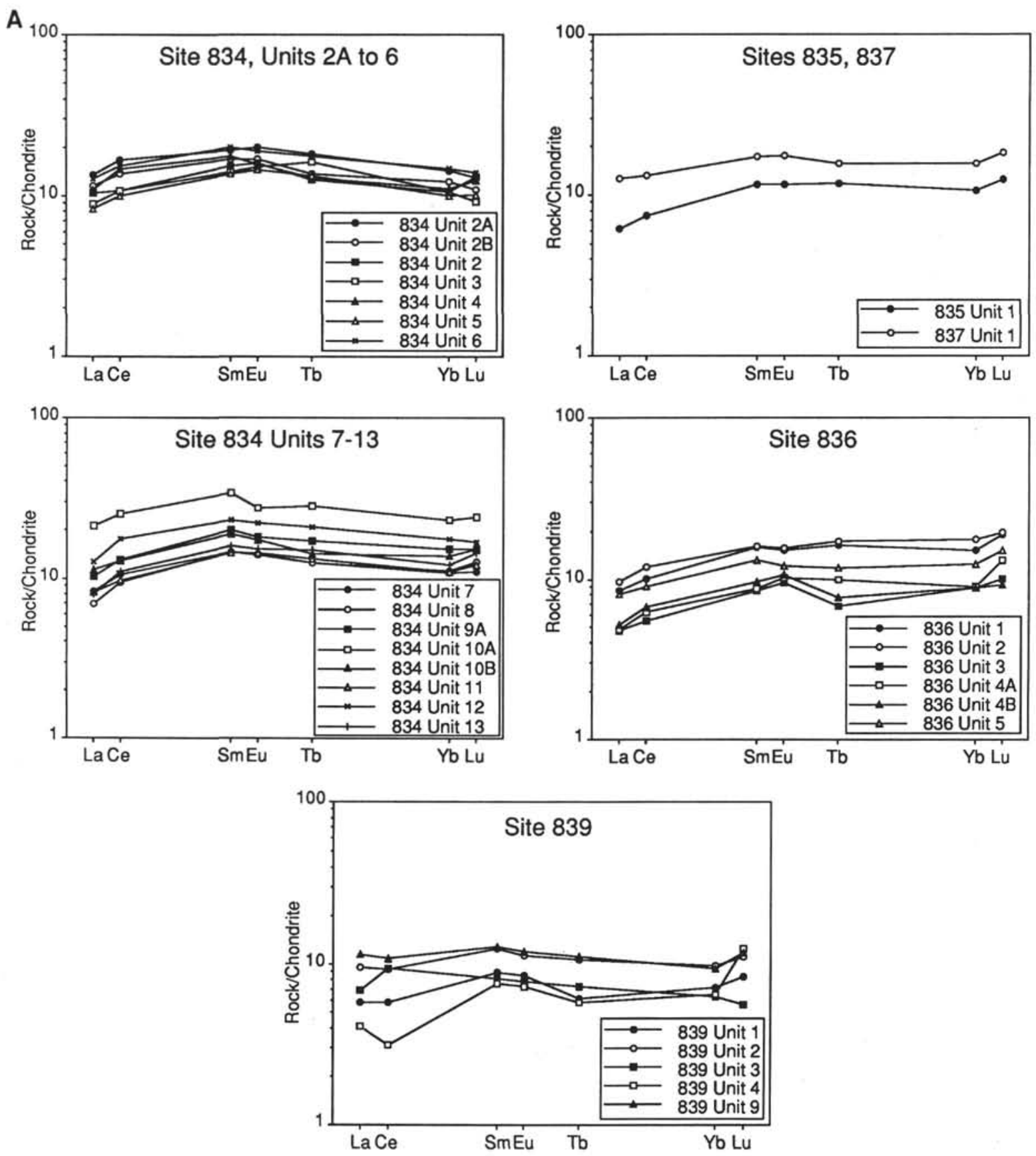

Figure 9. A. Lau Basin drill-site data for REE normalized to chondrite values (Masuda et al., 1973). Data determined by INAA (J.F. Allan, analyst). B. Comparison of REE data for Lau Basin backarc drill sites (Hawkins and Melchior, 1985; J. Hawkins, unpubl. data).

mantle source had experienced previous depletions in all magmaphilic elements and had subsequent variable enrichment in a subduction component. A similar petrogenetic history is inferred for arc-magma systems and is a characteristic of SSZ magmatism.

We consider first the REE; they are shown normalized to the Leedy chondrites (Masuda et al., 1973) in Figure 9A. The REE data offer some of the most compelling evidence to support our inference that the Lau Basin mantle source is depleted in REE and resembles a MORB source. The $(\mathrm{La} / \mathrm{Sm})_{\mathrm{N}}$ (chondrite-normalized) ratios range from 0.5 to 0.8 for all of the data; this gives them patterns convex upward like those for N-MORB. Specifically, the $(\mathrm{La} / \mathrm{Sm})_{\mathrm{N}}$ range for Sites 834 through 836 is $0.5-0.7$ and the range for Sites 837 and 839 is $0.5-0.8$. A ratio $<1$ is considered indicative of a source much more depleted than "typical" arc-source mantle, in which the ratio would commonly be nearly 1 or higher, that is, enriched in LREE (Gill, 1970; Ewart and Hawkesworth, 1987). The similarity in shape of the patterns for mafic and intermediate composition rocks indicates that the absolute abundances of the REE are mainly controlled by fractionation of olivine and plagioclase. Even though plagioclase is an important phenocryst constituent in all samples, only the most evolved sample (Subunit 10A) shows a slight Eu anomaly. In considering the samples with the least fractionated patterns from each site, note that there is a progressive depletion from Site 834 to Site 836 . Each of the lowest patterns is from samples with comparable Mg numbers. Melting at each site may have sampled sources with a varied extent of depletion, the extent of melting at each site was different, or both. Site 836 is located close to the ELSC and has patterns similar to it. These are depleted relative to both the Site 834 and CLSC samples. Site 834 


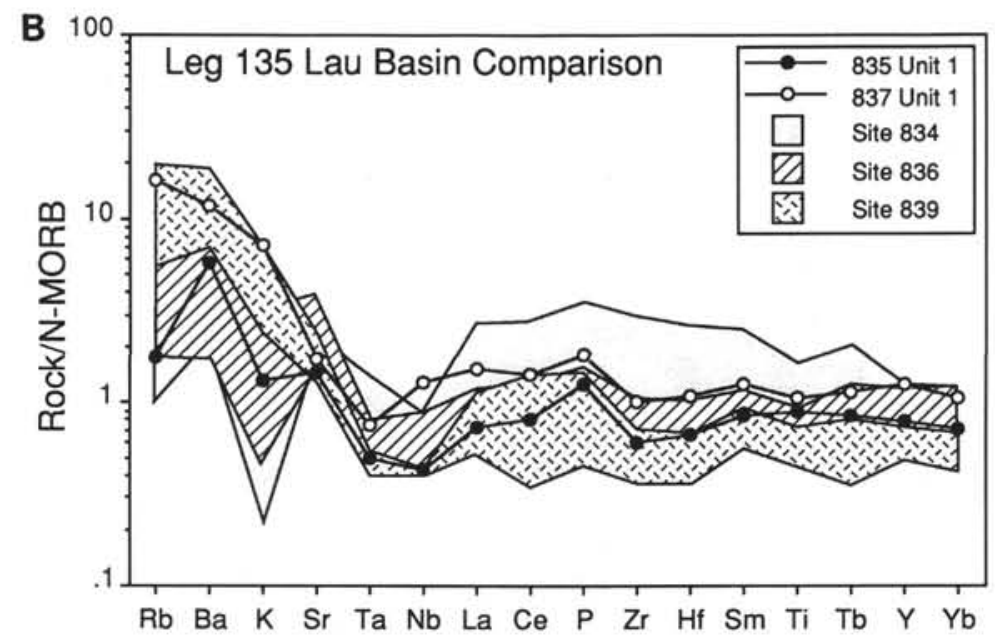

Figure 9 (continued).

crust formed before the CLSC propagator passed by to the east, but the REE pattern is similar to CLSC patterns. This suggests that longlived regional source differences (e.g., variable depletion) may have been important in petrogenesis.

Trace element and REE data for Site 837 (Figs. 8-9) show LIL enrichments that are typical of the Mariana Trough type basalts as well as having their relatively flat, chondrite-normalized REE pattern (Hawkins and Melchior, 1985). The limited data suggest fractionation of a MORB-like parent. All of the Site 839 samples have flatter, more arc-like REE patterns, and lower abundances than those for the other drill sites. Unit $4(\mathrm{Mg} \#=67)$ has the lowest REE abundances of any we analyzed and implies derivation from a depleted source. The most evolved Site 839 sample, from Unit $9(\mathrm{Mg} \#=47)$, has a nearly flat pattern as do many low-K arc tholeiites (Gill, 1970; Ewart and Hawkesworth, 1987). All patterns show an unusual upturn at Lu. The REE data determined by inductively coupled plasma mass spectrometry (ICP-MS) also show this unusual pattern (Hergt and Nilsson, this volume) for which we have no explanation. Comparison of REE data in Figure 9A shows that, except for the flattened pattern of Site 839, all have a MORB-like shape.

The evidence for a source depleted in REE is matched by the other HFSE data. Figure 8 shows similar depletions relative to N-MORB for $\mathrm{Ti}, \mathrm{Zr}, \mathrm{Y}, \mathrm{Nb}, \mathrm{Ta}$, and $\mathrm{Hf}$. The marked depletion in $\mathrm{Nb}$ and $\mathrm{Ta}$ is seen in the CLSC and ELSC as well. These HFSE are considered to be relatively immobile up to greenschist facies conditions and their concentrations are not likely to be modified by the addition of fluids derived from slab dehydration during subduction. Their abundance should give insight to help estimate the nature and extent of depletion of the SSZ source.

All HFSE show a negative correlation with indices of fractionation, such as $\mathrm{Mg}$ or $\mathrm{Ni}$, suggesting that fractional crystallization plays an important role in controlling HFSE abundances. Figure 10 shows the covariation of $\mathrm{Zr}$ with $\mathrm{Mg \#}$. Site 834 data indicate that parental melts had higher levels of $\mathrm{Zr}$ (e.g., lesser extent of melting) than for Sites 835 and 836 ; this is consistent with the $\mathrm{Na}$ data that suggest different extent of melting for these sites. A twofold increase in $\mathrm{Zr}$ for each magma series, as a result of fractional crystallization, is implied by the data.

$\mathrm{Y}, \mathrm{Zr}$, and $\mathrm{Ti}$ show linear arrays passing through zero in elementelement plots (Figs. 11-12), which suggests that they act as nearly ideal incompatible elements. Their relative abundances are related by crystal fractionation of low-pressure basalt liquidus phases having very low distribution coefficients, such as olivine and plagioclase, and minor amounts of clinopyroxene which has somewhat higher distribution coefficients. Clinopyroxene/liquid partition coefficients for $\mathrm{Ti}$ and $\mathrm{Y}$ are greater than those for $\mathrm{Zr}$. Model fractional crystallization

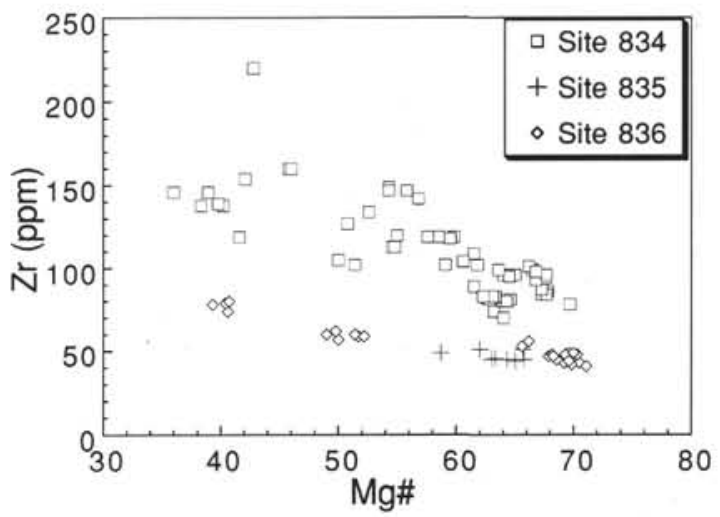

Figure 10. Drill-site data, showing covariance of $\mathrm{Zr}$ with $\mathrm{Mg} \#$ where $\mathrm{Mg \#}=$ $\left[100 *\left[\mathrm{Mg} /\left(\mathrm{Mg}+\mathrm{Fe}^{2+}\right)\right]\right\}$. Note that the $\mathrm{Zr} / \mathrm{Mg} \#$ for Site 834 is about twice that for Sites 835 and 836 .

paths (Fig. 11) were calculated to simulate hydrous ( $\operatorname{arc}$ ) conditions and anhydrous (MORB) conditions. Path W models a hydrous environment in which melts evolve by sequential fractionation of $20 \%$ olivine, followed by $20 \%$ crystallization of wehrlite ( 0.6 olivine plus 0.4 clinopyroxene), then by fractionation of gabbro ( 0.5 plagioclase, 0.2 olivine, 0.3 clinopyroxene). Path $\mathrm{T}$ is for the MORB sequence in which troctolite ( 0.6 olivine, 0.4 plagioclase) was used instead of wehrlite. Two different parental melt compositions were used: (1) 40 $\mathrm{ppm} \mathrm{Zr}$ and $15 \mathrm{ppm} \mathrm{Y}$, and (2) $60 \mathrm{ppm} \mathrm{Zr}$ and $18 \mathrm{ppm} \mathrm{Y}$. Either the troctolite or wehrlite model fits the scatter in Site 834 data but the troctolite model may be a better fit for Sites 835 and 836. In either case, the parental melts would have been highly depleted in both Y and $\mathrm{Zr}$. The reasonably good fit for the calculated paths, and the negative correlation of these elements with $\mathrm{MgO}$, indicates the importance of low pressure fractionation and also helps to estimate source compositions. However, magma mixing between highly fractionated melts and more primitive melts cannot be ruled out completely for some of the data. It is important to recognize that these trends can only demonstrate a general model for the evolution of the magmas because the data from each site include samples from multiple flow units and few of these may have had a common parental magma.

There is good coherence between elements with similar bulk distribution coefficients (e.g., Ti and Y). Estimates of distribution coefficients for these HFSE indicate $D_{c p x}>D_{o p x}>D_{o l}$ (e.g., Ewart and Hawkesworth, 1987; Ulmer, 1989). The abundances of $\mathrm{Ti}, \mathrm{Zr}$, and Y in parental mafic melts are largely controlled by the original concen- 

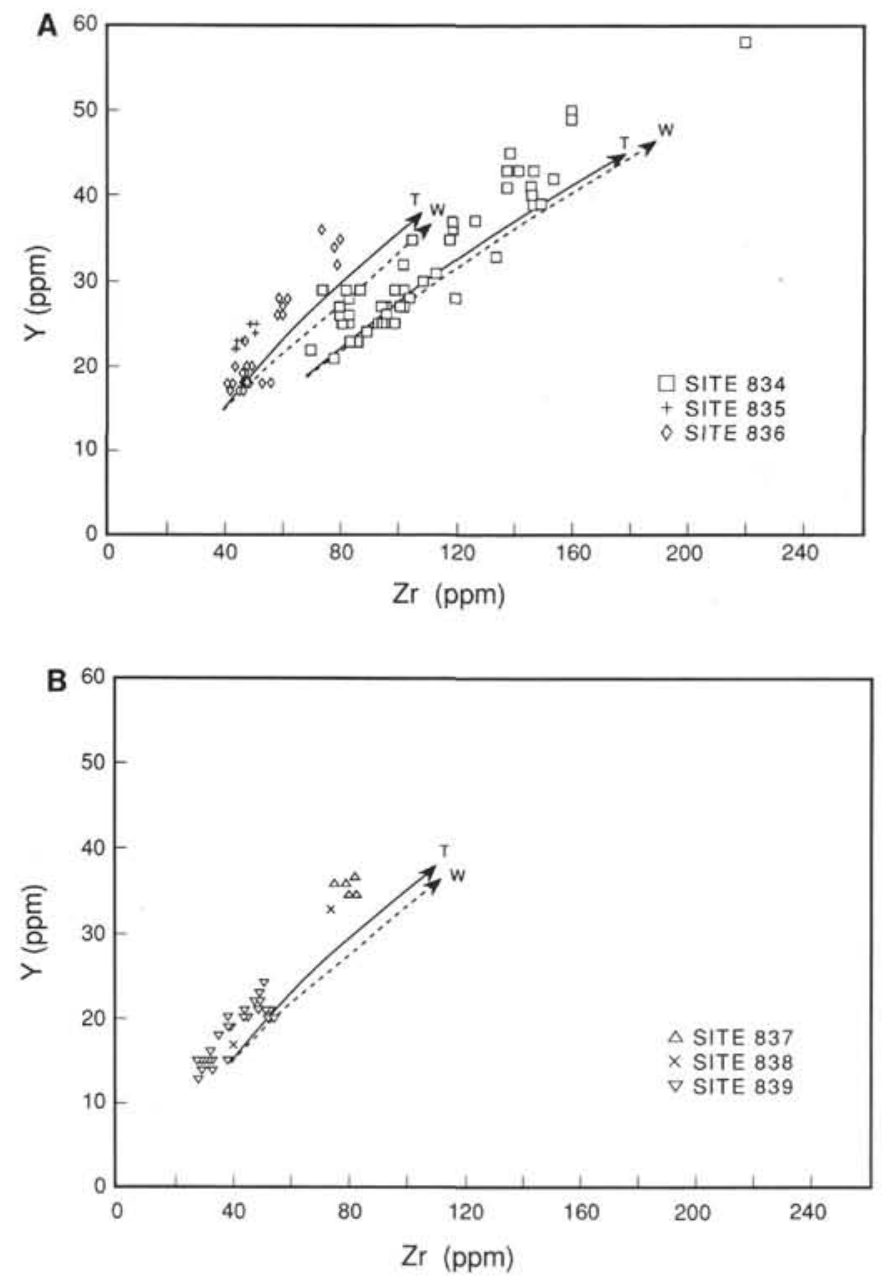

Figure 11. Drill-site data, showing covariance of $\mathrm{Y}$ with $\mathrm{Zr}$. Dashed lines are model fractionation trends for sequential removal of olivine-troctolite-gabbro (T) or olivine-wehrlite-gabbro (W) as discussed in the text. A. Sites 834 through 836 . B. Sites 837 through 839 . The $\mathrm{Y} / \mathrm{Zr}$ for Sites 835 and 836 shows a significant difference from that at Site 834 .

tration in the source and by the pyroxene content, mainly clinopyroxene. Both are a reflection of the previous extent of melting of the source although we recognize that the clinopyroxene content of depleted mantle can be modified by the addition of pyroxene-rich melts (Takazawa et al., 1992).

Inasmuch as $\mathrm{Ti}, \mathrm{Zr}$, and $\mathrm{Y}$ are highly incompatible elements, their ratios in least fractionated "primitive" or parental melts should approach mantle source values. The MORB-source mantle has $\mathrm{Y} / \mathrm{Zr}$ close to 0.35 , and a well-defined field for MORB is present in the $\mathrm{Y}-\mathrm{Zr}$ space between ratios of 0.3 and $0.4 \mathrm{Ti}$ and $\mathrm{Zr}$ show similar relations; the MORB ratio for $\mathrm{Ti} / \mathrm{Zr}$ typically is between 90 and 110 . Intraoceanic arc systems (e.g., Tonga; Ewart and Hawkesworth, 1987) have higher $\mathrm{Y} / \mathrm{Zr}$ ratios (e.g., $>0.4$ ), probably reflecting preferential $\mathrm{Zr}$ depletion in the source. For similar reasons, arc systems usually have high $\mathrm{Ti} / \mathrm{Zr}$ ratios (e.g., $>>100$ ), even though both elements are depleted relative to MORB. The strongly depleted boninitic series magmas, presumed to be formed in SSZ settings (e.g., Bloomer and Hawkins, 1987), have both very low $\mathrm{Ti} / \mathrm{Zr}(\ll<40)$ and $\mathrm{Y} / \mathrm{Zr}(<0.3)$. Part of the explanation for these low ratios may be caused by the addition of $\mathrm{Zr}$ by trondhjemitic partial melts of subducted lithosphere (Pearce et al., 1992). Drill-site data for Y vs. $\mathrm{Zr}$ and $\mathrm{Ti}$ vs. $\mathrm{Zr}$ define different element/element ratios for each site, although all are close to the MORB values for $\mathrm{Y} / \mathrm{Zr}(0.3-0.4)$ and $\mathrm{Ti} / \mathrm{Zr}(90-110)$. We inter-
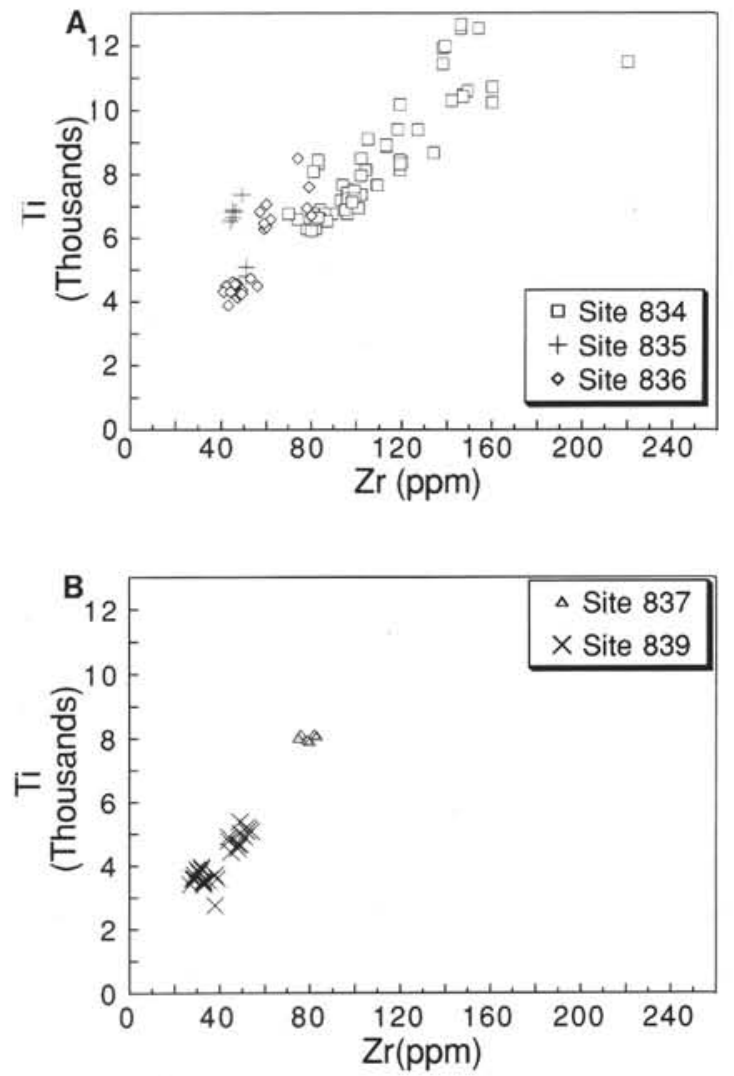

Figure 12. Drill-site data, showing covariance of $\mathrm{Ti}$ with $\mathrm{Zr}$. A. Sites 834 through 836 . B. Sites 837 through 839 . Site $834 \mathrm{Ti} / \mathrm{Zr}$ differs from that at Sites 835 and 836 as does the $\mathrm{Zr} / \mathrm{Y}$.

pret ratios for the least fractionated samples as signatures of their distinct mantle sources. For samples having more than $6 \% \mathrm{MgO}$, these are as follows: Site 836 has MORB-like $\mathrm{Ti} / \mathrm{Zr}(88-105)$ and $\mathrm{Y} / \mathrm{Zr}$ $(0.32-0.49)$; Site 835 has arc-like $\mathrm{Ti} / \mathrm{Zr}(100-153)$ and $\mathrm{Y} / \mathrm{Zr}(0.47-$ $0.51)$; and Site 834 has $\mathrm{Ti} / \mathrm{Zr}(69-102)$ and $\mathrm{Y} / \mathrm{Zr}(0.25-0.39)$. The drill-site trends project back to different $\mathrm{Zr}$ concentrations in parental melts. The least fractionated Site 834 samples have higher $\mathrm{Zr}$ (70-100 $\mathrm{ppm}$ ) than comparable samples from Sites 835 and $836(40-50 \mathrm{ppm})$. As discussed above, this may be the result of different extent of melting to form parental melts.

Average ratios for each of the Site 834 units show variations that may be caused by variations in the abundance of $\mathrm{Zr}$. There is a weak correlation with depth in which the oldest and youngest units have the highest ratios (lower $\mathrm{Zr}$ ), but the stratigraphic variations in ratios for each unit suggest episodicity. A nonlinear progressive decrease occurs from Units 13 to 9 , and a nearly linear trend from Units 6 to 1. Unit 8 has ratios nearly as large as those for Unit 13 . These variable depletions in HFSE are assumed to be a reflection of the SSZ mantle source. The intersite variations are best explained as a result of either different HFSE abundances in the source or the different extent of melting of a homogeneous source. However, we cannot exclude the possibility that the mantle source had been uniformly depleted in HFSE and then selectively reenriched with silicic melts derived from amphibole-rich assemblages such as older oceanic crust. This may be the best explanation for some of the variability found at Site 834, where the samples all have similar $\mathrm{Ti} / \mathrm{Y}$ but variable $\mathrm{Ti} / \mathrm{Zr}$ and $\mathrm{Y} / \mathrm{Zr}$ (averages for each petrologic unit range from 70 to 89 and from 0.25 to 0.32 , respectively).

Sites 837 and 839 have arc-like abundances and ratios for $\mathrm{Ti}, \mathrm{Zr}$, and Y. None of the Site 837 samples has more than $6 \% \mathrm{MgO}$; thus, they are evolved rocks, but they have $\mathrm{Zr}<80 \mathrm{ppm}, \mathrm{Y}<40 \mathrm{ppm}, \mathrm{Ti} / \mathrm{Zr}$ 

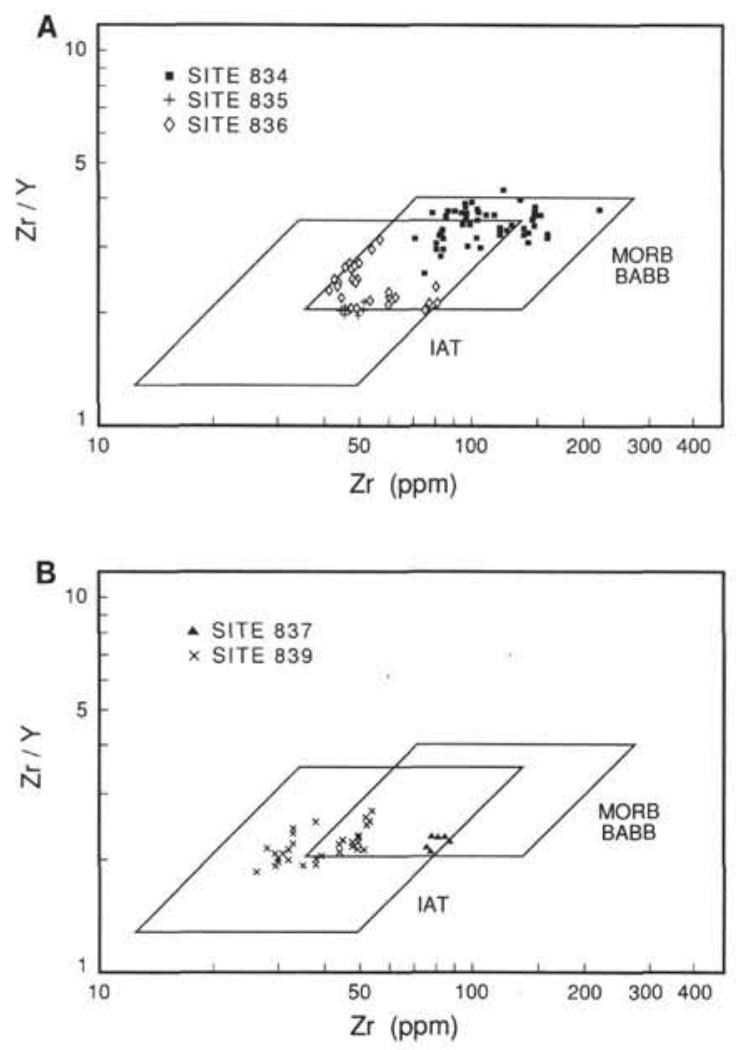

Figure 13. Drill-site data, showing covariance of $\mathrm{Zr} / \mathrm{Y}$ with $\mathrm{Zr}$. IAT = island-arc tholeiite field, $\mathrm{MORB}=$ mid-ocean-ridge basalt field. After Pearce and Cann (1973). A. Sites 834 through 836. B. Sites 837 through 839 . Note the large overlap of backarc magma systems with IAT and MORB fields.

$>105$, and $\mathrm{Y} / \mathrm{Zr}=0.4-0.5$. Site 839 samples, with $>6 \% \mathrm{MgO}$, have $\mathrm{Zr}<35 \mathrm{ppm}, \mathrm{Y}<15 \mathrm{ppm}, \mathrm{Ti} / \mathrm{Zr}>110$, and $\mathrm{Y} / \mathrm{Zr}=0.4-0.56$. The limited data did not warrant modeling the fractionation.

The discriminant diagram for $\mathrm{Zr}$ vs. $\mathrm{Zr} / \mathrm{Y}$ (Fig. 13) shows the overlap of the drill-site data with fields for MORB and island-arc tholeiite (IAT). This may be useful as a guide in recognizing ophiolites derived from SSZ arc-backarc settings.

A characteristic of nearly all Lau Basin samples is their low abundances of $\mathrm{Nb}$ and $\mathrm{Zr}$ relative to $\mathrm{N}-\mathrm{MORB}$, with $\mathrm{Nb}$ being especially depleted. $\mathrm{Nb}$ depletion appears to be a distinctive characteristic of SSZ mantle-derived magmas. $\mathrm{Nb}$ and $\mathrm{Zr}$ are both highly incompatible elements, and bulk distribution coefficients for mantle melting are very low (e.g., $\mathrm{Zr}=0.04, \mathrm{Nb}=0.01$; Mattey et al., 1980). Nb should be lost preferentially during melting of the source. Data shown in Figures 8-9, and listed in Appendix B, suggest that the source had been (partly) depleted in previous melting events. The drill-core samples from Sites 834 through 836 retain a MORB-like $\mathrm{Zr} / \mathrm{Nb}$, even though both elements are depleted relative to MORB. In contrast, Sites 837 839 have arc-like $\mathrm{Zr} / \mathrm{Nb}$.

The Hf/3-Ta-Th plot (Fig. 14) has been used to delineate magma sources on the basis of relative enrichments or depletions in Th and the $\mathrm{Hf} / \mathrm{Ta}$ ratio. Thorium is considered to be a tracer of relative depletion of the mantle. Higher levels may reflect a subduction component. The Hf/Ta ratio reflects relative depletion because Ta has lower partition coefficients than Hf. All of the Lau Basin data lie near the Hf end of the plot and show only minimal Th; this suggests that the source is depleted. Some of the drill-site data from Site 834, and all for Site 835 , lie in the SSZ field, but Site 836 and nearly all for Site 834 plot in the MORB field. Note that most of the Site 834 data are shifted away from the MORB-source value toward $\mathrm{Hf}$, implying preferential loss of Ta and Th in the backarc magma source. Curiously, the samples

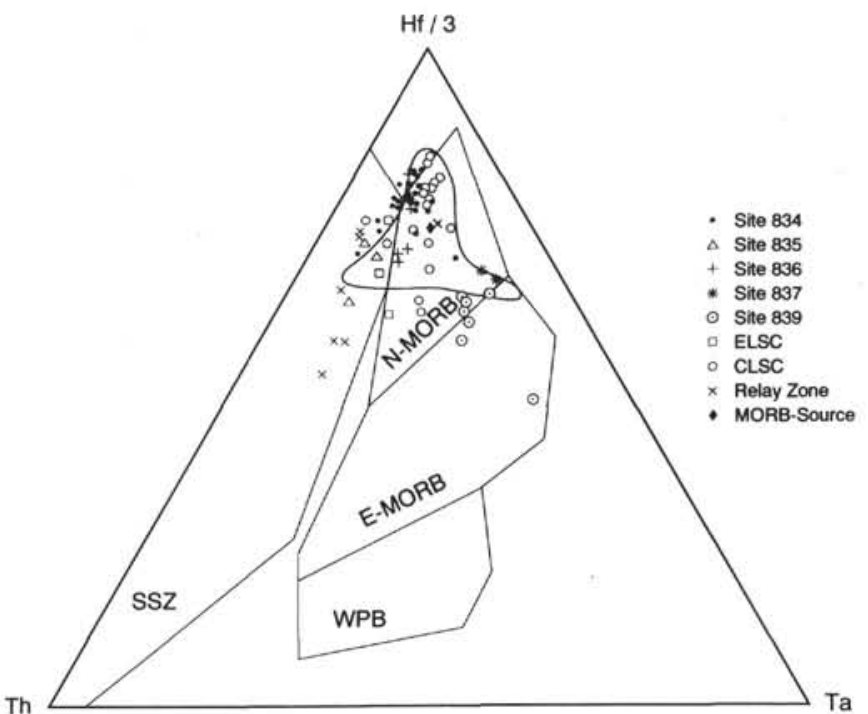

Figure 14. Drill-site data, showing Hf/3-Ta-Th data compared to ELSC, CLSC, and Relay Zone of Lau Basin. Shaded pattern represents the field for Site 834 samples (from Ewart et al. and Hergt and Nilsson, both in this volume). Fields shown are after Wood (1980) and Wood et al. (1981).

from the relay zone between the ELSC and CLSC are the only ones that lie in the SSZ field. Even the Sites 837 and 839 samples, those otherwise most like arc compositions, are largely in the N-MORB field. The extremely low Th abundances are important as an indicator of source chemistry. Th has long been considered to be a relatively immobile element that is scavenged by particulate material from seawater and remains fixed in sediment rather than being mobilized in fluid phases such as subduction-derived dehydration fluids. Quantitative data are lacking, but there is a high probability that $\mathrm{Th}(\mathrm{OH})_{4}$ may be stripped from sediments at elevated temperature and transported in the dehydration fluids in much the same way as B and Be (J. Gieskes, pers. comm., 1992).

Diagrams such as Hf/3-Ta-Th are commonly used to interpret the original tectonic setting for ophiolites, but here we use them to demonstrate the chemical signatures for the backarc basin samples as compared with MORB or arc (SSZ) suites. The plots demonstrate the range in backarc data and that they carry the signature of both MORB and SSZ. This clearly is important to ophiolite studies in which diagrams of this type would be used to discriminate between MORB and arc origins. Used uncritically, an incorrect interpretation would be made because backarc basins do not carry a unique signaturethey may span the IAT/MORB fields.

The variation of $\mathrm{Ni}$, a compatible element, with $\mathrm{Zr}$, an incompatible element, is shown in Figure 15. Model paths for fractionation of an "anhydrous" assemblage with sequential crystallization of olivinetroctolite-gabbro (i.e., MORB-like) is shown for parental melts with 40,50 , and $100 \mathrm{ppm} \mathrm{Zr}$, all with $150 \mathrm{ppm} \mathrm{Ni}$. The element ratios may be explained by these generic crystallization models but the scatter suggest that some Site 834 units may have been modified by magma mixing between highly fractionated and less evolved melts. The trends for Sites 835 and 836 data fit the troctolite model well; Site 834 data appear to fit the troctolite model but the resolution is poor.

Interpretation of the LILE data ( $\mathrm{Rb}, \mathrm{Ba}$, and $\mathrm{Sr}$; Appendix B and Table 4) is not as simple as for the HFSE data because of their mobility in low-temperature processes. A major factor is that the data are from rocks rather than glass and all samples show some degree of alteration. Data for glasses (Hergt and Nilsson, this volume) show that Rb values are typically $<2$ ppm and most are $1 \mathrm{ppm}$ or less; $\mathrm{Ba}$ is $<30 \mathrm{ppm}$ in most glass samples. Both $\mathrm{Rb}$ and $\mathrm{Ba}$ tend to be higher in the rocks. The $\mathrm{Rb}-\mathrm{Zr}$ (not shown) and $\mathrm{Ba}-\mathrm{Zr}$ diagrams (Fig. 16) show much 


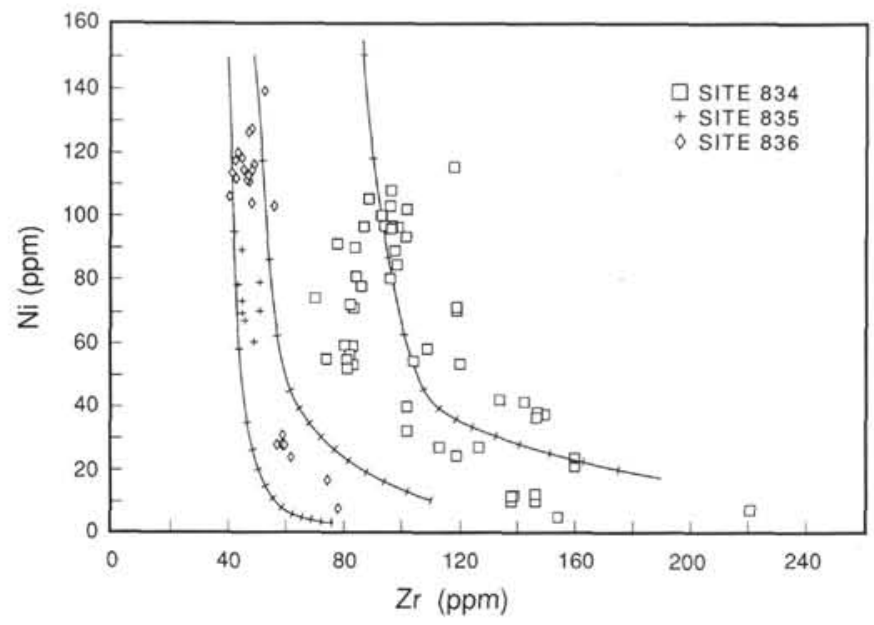

Figure 15. Trace element data for Sites 834 through 836, showing covariance of $\mathrm{Ni}$ with $\mathrm{Zr}$. Curved lines are model fractionation trends as described for Figure 12. Tick marks are for successive 5\% fractionation increments,

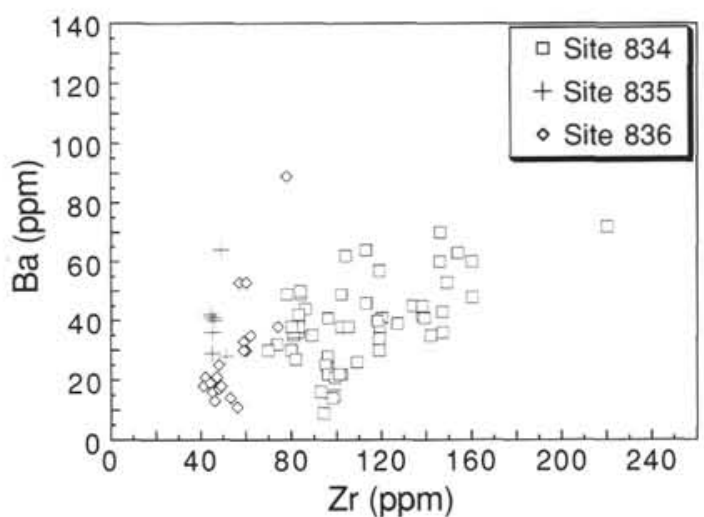

Figure 16. Drill-site data, showing scatter of data for Ba vs. $\mathrm{Zr}$ at Sites 834 through 836 .

scatter especially for Site 834. Fractional crystallization does not explain the scatter of data. Site 836 provides the most coherent picture for $\mathrm{Ba}-\mathrm{Zr}$, but the trend is difficult to explain by fractionation. Enrichment in $\mathrm{Rb}, \mathrm{Ba}$, and $\mathrm{Sr}$ could be caused by several factors, including low-temperature alteration, assimilation of sediments or altered basaltic crust, or primary magma variations that are related to the source (e.g., SSZ mantle).

The Sr data (Fig. 17) may be more useful as a source indicator than $\mathrm{Rb}$ and $\mathrm{Ba}$ because the latter are highly susceptible to near-surface alteration effects. Glass data for $\mathrm{Sr}$ are similar to our rock data, suggesting that alteration has not significantly modified the $\mathrm{Sr}$ in these samples. Sr enrichment is considered to be an indicator of arc-like (SSZ) affinity; for example, $\mathrm{Sr} / \mathrm{Zr}$ ranges from 5 to 11 in the Tofua Arc volcanoes (Ewart and Hawkesworth, 1987). Samples from Sites 834 through 836 all have MORB-like $\mathrm{Sr} / \mathrm{Zr}$ (1.0-2.3); ELSC and CLSC rocks and glasses are similar. The drill-site $\mathrm{Sr}-\mathrm{Zr}$ data may be explained largely by fractional crystallization, as shown in Figure 17. Troctolite models and wehrlite models were calculated for parental liquids having (1) $120 \mathrm{ppm} \mathrm{Sr}$ and $55 \mathrm{ppm} \mathrm{Zr}$, or (2) $120 \mathrm{ppm} \mathrm{Sr}$ and $65 \mathrm{ppm} \mathrm{Zr}$. The same crystallization sequence was used as for $Y$ and $\mathrm{Zr}$. The wehrlite model was intended to test a hydrous melt system, and the troctolite model to evaluate an anhydrous one. The youngest petrologic units at Site 834 (Units 1-5) and the oldest (Unit 13) follow the wehrlite model, whereas Units 6-12 follow the anhydrous troctolite model. This suggests that the earliest melts came from a hydrous

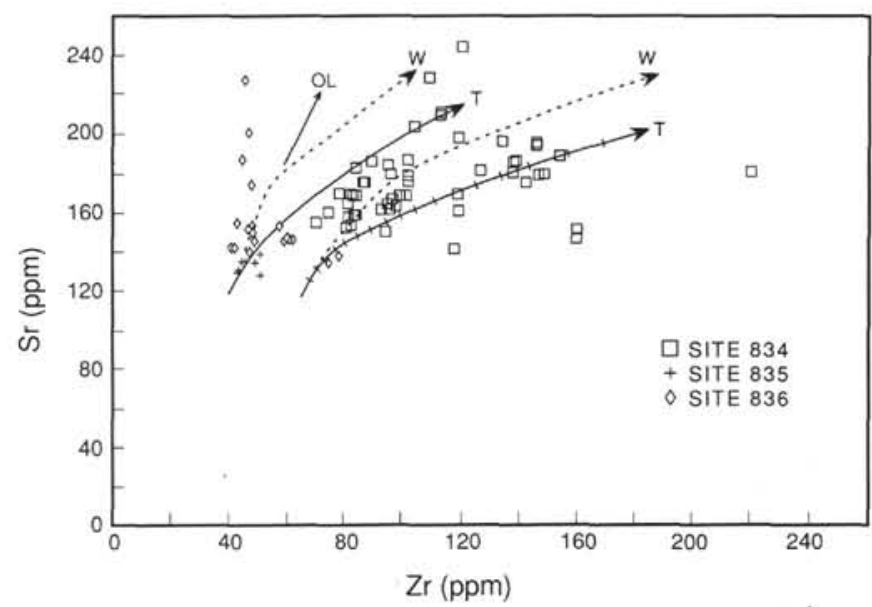

Figure 17. Drill-site data showing covariation of $\mathrm{Sr}$ with $\mathrm{Zr}$ at Sites 834 through 836. Curved lines are model fractionation trends as described for Figure 12.

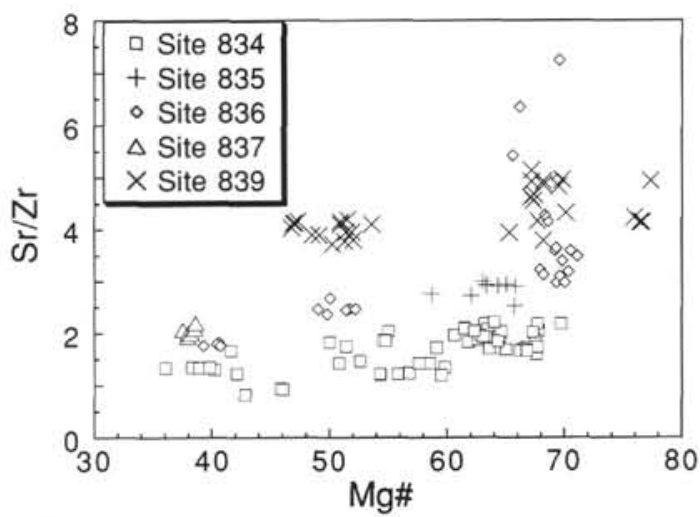

Figure 18. Drill-site data, showing covariance of $\mathrm{Sr} / \mathrm{Zr}$ with $\mathrm{Mg} \#$ at Sites 834 through 839. Each site appears to have a distinctive $\mathrm{Sr} / \mathrm{Zr}$ ratio.

source and that the intermediate stage, including most of our samples, came from a less hydrous source. Sites 835 and 836 may have had anhydrous sources because they follow the troctolite model. Some high-Sr data (e.g., some of the Site 836 samples and Units 1-2 at Site 834 ) are not explained by these models. The Site 834 samples are thin flows or gravels intercalated with nannofossil clayey mixed sediments that may have contaminated the magmas.

$\mathrm{The} \mathrm{Sr} / \mathrm{Zr}$ relations for each site show some coherent patterns in comparison with $\mathrm{Mg \#} \mathrm{(Fig.} \mathrm{18).} \mathrm{Each} \mathrm{site} \mathrm{has} \mathrm{rather} \mathrm{well-constrained}$ values, each with its own $\mathrm{Sr} / \mathrm{Zr}$ signature, at an $\mathrm{Mg} \#$ greater than 50 . We interpret these as distinct source characteristics. These are essentially MORB values at Sites 834 and 835 , and arc values at Site 839 . Site 836 includes both MORB and arc values. The low $\mathrm{Sr} / \mathrm{Zr}$ at Site 837 probably is the result of $\mathrm{Zr}$ enrichment (coupled with plagioclase fractionation?) in these highly evolved rocks.

Collectively, the $\mathrm{Sr}$ data do not give much support for a significant subduction component in the parental melts, although this cannot be totally excluded. The $\mathrm{Sr}$-isotope data offer a better test for this, and we note that the data of Hergt and Hawkesworth (this volume) show that most of the Site 834 lavas are similar to MORB (e.g., ${ }^{87} \mathrm{Sr} /{ }^{86} \mathrm{Sr}=$ $0.7025-0.7028$, with only a few samples reaching 0.7030 ). The MORBlike character of Site 834 basalts also is reflected in the relatively low abundances of LILE, and the MORB-like abundances of both REE and HFSE in comparison to arc magmas at comparable $\mathrm{MgO}$ levels. Although the Sr-isotope data for Site 834 lavas are MORB-like, Sr-isotope ratios for most of the Lau Basin rocks are not typical of MORB values, as will be discussed subsequently. Many of the HFSE 
data are on the low side of the MORB range, but they are not as low as is common in arc magmas.

\section{Petrogenesis}

One of the main petrologic objectives for the Lau Basin drilling transect was to evaluate the role of SSZ mantle sources in forming Lau Basin crust. The SSZ signature has two components. The depleted signature is the consequence of previous melt extraction, for example, generation of MORB. Depletion of HFSE in SSZ magmas is well established. The LILE signature is variable and more difficult to identify if samples are altered. The evidence for it is seen in the sites near the ELSC but it is weak. In addition to the SSZ component, evidence is present in the Lau Basin for a mantle component carrying Indian Ocean ridge isotopic signatures (Volpe et al., 1988; Loock et al., 1990; Hergt and Hawkesworth, this volume). This mantle counterflow component was proposed by Hawkins and Melchior (1985) on the basis of trace element data, but the isotopic data to support it were lacking at that time.

Our new data, together with data from previous studies, enable us to make a first-order separation of the sample sites into a MORB-like set (Sites 834-836), a transitional set (Sites 837-838), and an arc-like set (Site 839). Site 834 resembles CLSC rocks, and samples from Sites 835 and 836 show strong similarity to the ELSC. Hergt and Hawkesworth (this volume) show that the MORB set can be further separated into "Pacific" (Site 834) and "Indian" (Sites 835-836, CLSC, and ELSC) sets. The Pacific mantle may be a relic that predates basin opening. Samples from Sites 837 and 838 and some from Site 836 resemble the ELSC. Site 839 has the Pacific source isotopic signature (Ewart et al., this volume) and has many similarities to the Valu Fa Ridge and the modern Tofua Arc volcanoes.

The major element data indicate MORB-source mineral constituents in the source, but variable trace elements as discussed previously. Much of the intrasite variation can be explained by fractional crystallization at low pressure. All of the samples recovered have experienced at least moderate fractionation and none is a likely candidate for a parental melt. Evidence exists for magma mixing, as suggested by trace element data "perched" above model fractionation curves. Petrographic data, such as strong compositional zoning in phenocrysts, also suggests the presence of xenocrysts incorporated in new melt batches (cf. Allan, this volume). Intersite variations in the least fractionated samples may be caused by source heterogeneity, variable melting of the source, different depths of melt segregation, differential assimilation/zone refining, or combinations of these processes. For example, if we assume a homogeneous source under the basin, variations in $\mathrm{Na}$ (e.g., Klein and Langmuir, 1987) and other low partition coefficient elements may reflect the extent of melting. The data for $\mathrm{Na}$ and $\mathrm{HFSE}(\mathrm{Ti}, \mathrm{Zr}, \mathrm{Y}, \mathrm{Nb}$, and $\mathrm{Y} / \mathrm{Zr}$ ) all suggest a relative difference in the extent of source melting, from lowest to highest being Sites $834,836,835,837$ and 838 , and 839 . Alternatively, if a uniform extent of melting is postulated, this is the sequence of relative depletion of the source.

We have compared our data with Mariana Trough data (Figs. 3 and 6) and find both differences and similarities. Fryer et al. (1981) established that Mariana Trough basalts are distinctive in having relatively high $\mathrm{Al}_{2} \mathrm{O}_{3}$ and $\mathrm{Na}_{2} \mathrm{O}$, but low $\mathrm{FeO}^{*}$ and $\mathrm{TiO}_{2}$, in comparison with MORB. These are chemical characteristics of arc-series magmas as well, although the absolute levels of enrichment or depletion are greater in the arc magmas. A more extensive data set for the Mariana Trough (Hawkins et al., 1990) shows that most of the rocks from the Mariana Trough neovolcanic zone have the characteristics described by Fryer et al. (1981), although some of the neovolcanic zone glasses overlap with $\mathrm{N}-\mathrm{MORB}$ in $\mathrm{Al}_{2} \mathrm{O}_{3}-\mathrm{MgO}$ relations as well as other elements.

It has been proposed that SSZ magmas are enriched relative to MORB in $\mathrm{Al}_{2} \mathrm{O}_{3}$, but depleted in $\mathrm{FeO}^{*}$ and $\mathrm{TiO}_{2}$, because of the effects of increased $\mathrm{PH}_{2} \mathrm{O}$. Fryer et al. (1981) proposed this for the Mariana
Trough basalts. Water controls the relative stability of plagioclase, olivine, and clinopyroxene (Baker and Eggler, 1987; Michael and Chase, 1987; Sisson and Grove, 1993a, 1993b). Elevated $\mathrm{P}_{2} \mathrm{O}$ in the source should expand the primary phase volumes of both olivine and high-Ca clinopyroxene, shifting melts toward plagioclase (Sisson and Grove, 1990a). Melts are progressively enriched in $\mathrm{Al}_{2} \mathrm{O}_{3}$ before plagioclase saturation by crystallization of olivine and clinopyroxene; plagioclase crystallization is delayed. The hydrous, high $\mathrm{fO}_{2}$ magmas promote early crystallization of $\mathrm{Fe}$ and $\mathrm{Ti}$ oxides. If we accept this hypothesis, the range in element abundances suggests that Mariana Trough samples represent relatively more hydrous systems than the Lau Basin glasses. Among the Lau Basin samples, the Site 834 (oldest) glasses may be derived from the more hydrous system, although less so than from the Mariana Trough, whereas the CLSC glasses are least hydrous. The ELSC and Sites $835-839$ presumably are intermediate. Site 839 samples are the most arc-like in mineralogy and chemistry, yet the glasses are among the least aluminous samples we collected. This is contrary to what might be expected.

Plagioclase is a liquidus phase in all of the drill-site samples as well as in all of our dredged samples from the Lau Basin. This includes CLSC glass samples with $\mathrm{MgO}$ contents as high as $8.9 \%$. These observations lead us to question whether plagioclase crystallization was actually suppressed during the low-pressure evolution of the magmas. We know that the melts have higher water contents than typical MORB (e.g., 0.38\%; Hawkins and Melchior, 1985); plagioclase crystallization may have been inhibited in parental melts with $\mathrm{MgO}>9 \%$, but no evidence is present that it was suppressed even in the least evolved samples we have collected. As discussed above, the parental melts may have had higher $\mathrm{Al}$ contents as a result of expansion of the primary phase volumes of olivine and high-calcium clinopyroxene as a result of increased $\mathrm{P} \mathrm{H}_{2} \mathrm{O}$ (Sisson and Grove, 1993a). Plagioclase crystallization may have been suppressed at higher pressures, but rapid degassing at low-pressure (e.g., forming the abundant vesicles) may have promoted rapid plagioclase growth from melts saturated in plagioclase.

\section{SUMMARY AND CONCLUSIONS}

Several models for Lau Basin evolution are presented elsewhere in this volume (Ewart et al; Hergt and Nilsson; Parson and Hawkins; Hawkins). A brief summary of our view is given here. A simple view of backarc evolution is that crustal extension, accompanied by true seafloor spreading, generates new crust throughout the history of the basin. However, we visualize a more complex history for the Lau Basin that probably applies to other backarc systems as well. The formation of the Lau Basin has involved crustal extension that accompanied partial dismembering of the Lau Ridge. Fragments of former Lau Ridge basement are found on the Tonga platform and forearc. Lau Basin crustal extension involved two different styles of deformation (Parson and Hawkins, this volume). Initial extension, beginning about 6 m.y. ago, involved progressive crustal thinning and rifting that formed a series of grabens or half-grabens. The result is basin-rangetype morphology and structure that forms the seafloor of the entire western Lau Basin; smaller areas, with similar morphology, are found on the eastern and northeastern edge of the basin. The rifting was accompanied by basaltic volcanism that, together with rapid sedimentation, has partly filled the rift basins. At least 2-3 m.y. of magmatic activity is recorded in the narrow basin sampled at Site 834. Either the crust was extended very slowly in the initial stage of opening, or there was massive upwelling of hot mantle that provided long-term melting in a very restricted region. We have no idea of the longevity of magmatism, or the nature of the earliest melts, at Site 834 as the Leg 135 drill cores recovered only products of the waning phases of this volcanism together with interbedded arc-derived clastic sediments.

The earliest backarc magmatism (Site 834) came from mantle having the HFSE depletion of SSZ mantle but without extensive LILE enrichment. That is, a multiply-depleted, MORB-source mantle. The 
Site 834 source experienced only a moderate extent of melting relative to the extent of melting inferred for the younger sites and the present axial ridges. This is implied by high $\mathrm{Na}_{2} \mathrm{O}$ (e.g., $3 \%$ at $8 \% \mathrm{MgO}$ ) and $1.3 \%-1.5 \% \mathrm{TiO}_{2}$, as well as relatively high abundances of low-partition coefficient elements such as $\mathrm{Zr}$. Backarc magmas at Site 834 were erupted while the Lau Ridge volcanic arc was still active and also experiencing crustal rifting. The two magma systems must have sampled totally different mantle sources in spite of their proximity to one another. Subsequent magmatism, sampled at Sites 835 and 836, also came from a depleted mantle having MORB-source characteristics. Abundances of $\mathrm{Na}, \mathrm{Ti}$, and HFSE suggest a greater extent of melting than at Site 834.

The setting for early "backarc" magmatism must have been in the forearc or at the eastern foot of the Lau Ridge. An argument may be made that the arc should have been the more likely site of rifting because thicker crust, dominated by quartz and feldspar, would be more brittle and weaker (P. Fryer, pers. comm., 1993). Inasmuch as the Lau Ridge remained active after rifting, it comprises mafic and intermediate lavas, and the present forearc has the most siliceous rocks in the region (cf. the low-K rhyolite of Site 841; Bloomer et al., this volume), the forearc to the Lau Ridge arc may have been the most likely place for rifting. The present forearc (part of the Tonga Ridge) has distal facies of Miocene volcaniclastic turbidites that were derived from the Lau Ridge as well as fragments of the pre-Miocene basement. These rocks, now exposed at Site 841 (Parson, Hawkins, Allan, et al., 1992; Bloomer et al., this volume) and on the island of 'Eua, were rifted from the Lau Ridge while the active arc remained behind.

The second phase (style) of tectonic activity involved crustal extension by seafloor spreading from propagating rifts (Parson et al., 1990; Parson and Hawkins, this volume). The first propagator began to extend southward from the Peggy Ridge at about 5.5-4.5 Ma; this formed the ELSC. A second propagator began from near the same area at about 1.5-1.2 Ma; this formed the CLSC. Site 836 crust formed by spreading on the ELSC; the magmas probably formed by a greater extent of melting than those at Sites 834 and 835 . The Site 836 melts came from a depleted MORB-source mantle like the source for modern CLSC and ELSC axial ridge lavas.

The driving force for basin extension is postulated to be mantle upwelling above the subduction zone. The upwelling probably resulted from mantle counterflow driven by subduction and the seaward retreat of the Tonga Trench (e.g., Hawkins et al., 1984). Lau Basin magmatism is dominated by the signature of depleted SSZ mantle with variable, but lesser, influence of the LILE-enriched subduction component. The robust MORB-like signature seen throughout the basin, but especially on the axial ridges, must be the result of melting of MORB-source mantle rising as diapirs above the subduction zone. As the basin has opened, the locus of magmatism appears to have tracked the eastward migration (rollback) of the Tonga Trench, giving rise to an asymmetric distribution of rock ages in the backarc basin.

As the locus of melting progressively moved out into the enriched mantle wedge, arc-composition (SSZ) melts also were formed in addition to the MORB-like basalts that filled the rift basins. The arc lavas formed small, ephemeral, intra-basin, arc-like volcanoes (Clift and Dixon; this volume). Debris and flows from these were sampled at Sites 837 and 838 . The arc-composition rocks at Site 839 may be from a small edifice cut off and abandoned by ridge propagation (see also Ewart et al., this volume). The ridge propagation caused MORBlike crust to surround or engulf the isolated arc-composition features.

The Leg 135 drilling transect has increased our understanding of the geology of the Lau Basin but has posed new problems as well. Among the more intriguing questions raised is the origin of the spectrum of magma types found, especially the tracts of arc-like rocks within the backarc basin. Much time and space in the literature has been devoted to debating whether backarc basalts are a variety of MORB or a variety of arc lavas. Clearly, both types are found in backarc basins and no such thing as a specific kind of rock exists that we can call backarc basin basalt. The crustal heterogeneity we have documented here is not unique. Similar heterogeneity is seen in other backarc basins. The Mariana Trough (Fryer et al., 1981; Sinton and Fryer, 1987; Hawkins and Melchior, 1985; Hawkins et al., 1991), Sumisu Rift (Hochstaeder, Gill, Kusakabe, et al., 1990; Hochstaeder, Gill, and Morris, 1990), and North Fiji Basin (Johnson and Sinton, 1990) all include rocks transitional between N-MORB and arc-tholeiitic chemistry. The variations found in the Lau and other backarc basins suggest that they formed from SSZ magmas that are neither true arc nor true MORB but, depending upon the geologic history of their source, show varied chemical characteristics of each type. Mixing of melts from a multiply-depleted mantle source, which subsequently received variable reenrichment with a subduction component, is a primary control. An added complexity is the mantle counterflow that, in some basins, provides an influx of less depleted MORBsource, or ocean-island basalt-source, mantle. Perhaps the best term for backarc magmas is that they are SSZ magma systems.

It seems clear that much of the difficulty in determining the site of origin of ophiolites is resolved once one understands the nature of SSZ magmatism.

\section{ACKNOWLEDGMENTS}

This work was supported by grants from JOI-USSAC to JWH and JFA. It also draws on JWH's research that was supported by NSF Grant Nos. OCE 84-15472 and 87-16660. JWH gives special thanks to F. Florendo, who assisted with the chemical analyses. An original version of the manuscript was improved by many helpful comments from Julian Pearce and Patty Fryer.

\section{REFERENCES}

Allan, J.F., Sack, R.O., and Batiza, R., 1988. Cr-rich spinels as petrogenetic indicators: MORB-type lavas from the Lamont Seamount Chain, Eastern Pacific. Am. Mineral., 73:741-753.

Baker, D.R., and Eggler, D.H., 1987. Compositions of anhydrous and hydrous melts coexisting with plagioclase, augite, and olivine or low-Ca pyroxene from $1 \mathrm{~atm}$ to $8 \mathrm{kbar}$ : applications to the Aleutian volcanic center of Atka. Am. Mineral., 72:12-28.

Barazangi, M., and Isacks, B., 1971. Lateral variations of seismic-wave attenuation in the upper mantle above the inclined earthquake zone of the Tonga Island Arc: deep anomaly in the upper mantle. J. Geophys. Res., 76:8493-8516.

Billington, S., 1980. The morphology and tectonics of the subducted lithosphere in the Tonga-Kermadec-Fiji region from seismicity and focal mechanism solutions [Ph.D. dissert.]. Cornell Univ., Ithaca, NY.

Bloomer, S., Melchior, J., Evans, C., and Francis, R.D., 1985. Techniques for the chemical analysis of igneous rocks used at the Scripps Institution of Oceanography. SIO Ref. Ser., 85-10.

Bloomer, S.H., and Hawkins, J.W., 1987. Petrology and geochemistry of boninite series volcanic rocks from the Mariana trench. Contrib. Mineral. Petrol., 97:361-377.

Boespflug, X., Dosso, L., Bougault, H., and Joron, J.L., 1990. Trace element and isotopic ( $\mathrm{Sr}$ and $\mathrm{Nd}$ ) geochemistry of volcanic rocks from the Lau Basin. In von Stackelberg, U., and von Rad, U. (Eds.), Geological Evolution and Hydrothermal Activity in the Lau and North Fiji Basins, Southwest Pacific Ocean (Results of SONNE Cruise SO-35). Geol. Jahrb., 92:503-516.

Bryan, W.B., 1979. Regional variation and petrogenesis of basalt glasses from the FAMOUS area, Mid-Atlantic Ridge. J. Petrol., 20:293-325.

Bryan, W.B., Thompson, G., Frey, F.A., and Dickey, J.S., 1976. Inferred geologic settings and differentiation in basalts from the Deep Sea Drilling Project. J. Geophys. Res., 81:4285-4304.

Bryan, W.B., Thompson, G., and Ludden, J.N., 1981. Compositional variations in normal MORB from $22^{\circ}-25^{\circ} \mathrm{N}$ : Mid-Atlantic Ridge and Kane Fracture Zone. J. Geophys. Res., 86:11815-11836.

\footnotetext{
- Abbreviations for names of organizations and publication titles in ODP reference lists follow the style given in Chemical Abstracts Service Source Index (published by American Chemical Society).
} 
Cole, J.W., Gill, J.B., and Woodhall, D., 1985. Petrologic history of the Lau Ridge, Fiji. In Scholl, D.W., and Vallier, T.L. (Eds.), Geology and Offshore Resources of Pacific Island Arcs-Tonga Region. Circum-Pac. Counc. Energy Miner. Resour., Earth Sci. Ser., 2:379-414.

Cunningham, J.K., and Anscombe, K.J., 1985. Geology of 'Eua and other islands, Kingdom of Tonga. In Scholl, D.W., and Vallier, T.L. (Eds.), Geology and Offshore Resources of Pacific Island Arcs-Tonga Region. Circum-Pac. Counc. Energy Miner. Resour., Earth Sci. Ser., 2:221-258.

Dick, H.J.B., and Bullen, T., 1984. Chromian spinel as a petrogenetic indicator in abyssal and alpine-type peridotites and spatially associated lavas. Contrib. Mineral. Petrol., 86:54-76.

Ernewein, M., Pearce, J.A., Bloomer, S.H., Parson, L.M., Murton, B.J. Johnson, L.E., in press. Geochemistry of Lau Basin volcanic rocks: influence of ridge segmentation and arc proximity. In Smellie, J. (Ed.), Volcanism Associated with Extension at Consuming Plate Margins. Geol. Soc. Spec. Publ. London.

Ewart, A., Brothers, R.N., and Mateen, A., 1977. An outline of the geology and geochemistry, and the possible petrogenetic evolution of the volcanic rocks of the Tonga-Kermadec-New Zealand island arc. J. Volcanol. Geotherm. Res., 2:205-250.

Ewart, A., and Bryan, W.B., 1972. Petrography and geochemistry of the igneous rocks from 'Eua, Tonga Islands. Geol. Soc. Am. Bull., 83:32813298.

Ewart, A.E., and Hawkesworth, C.J., 1987. The Pleistocene-Recent TongaKermadec arc lavas: interpretation of new isotope and rare earth data in terms of a depleted mantle source model. J. Petrol., 28:495-530.

Falloon, T.J., Malahoff, A., Zonenshain, L.P., and Bogdanov, Y., 1992. Petrology and geochemistry of back-arc basin basalts from Lau Basin spreading ridges at 15,18 , and $19^{\circ} \mathrm{S}$. Mineral. Petrol., 47:1-35.

Fryer, P., Sinton, J.M., and Philpotts, J.A., 1981. Basaltic glasses from the Mariana Trough. In Hussong, D.M., and Uyeda, S., et al., Init. Repts. DSDP, 60: Washington (U.S. Govt. Printing Office), 601-609.

Fryer, P., Taylor, B., Langmuir, C.H., and Hochstaedter, A.G., 1990. Petrology and geochemistry of lavas from the Sumisu and Torishima backarc rifts. Earth Planet. Sci. Lett., 100:161-178.

Garcia, M.O., Liu, N.W.K., and Muenow, D.W., 1979. Volatiles in submarine volcanic rocks from the Mariana island are and trough. Geochim. Cosmochim. Acta, 43:305-312.

Gill, J.B., 1981. Orogenic Andesites and Plate Tectonics: New York (Springer-Verlag).

Glascock, M.D., Nabelek, P.I., Weinrich, D.D., and Coveney, R.R., Jr., 1986. Correcting for uranium fission in instrumental neutron activation. J. Radioanal. Nucl. Chem., 99:121-131.

Grove, T.L., Gerlach, D.C., and Sando, T.W., 1982. Origin of calc-alkaline series lavas at Medicine Lake Volcano by fractionation, assimilation and mixing. Contrib. Mineral. Petrol., 80:160-182.

Hart, S.R., Glassley, W.A., and Karig, D.E., 1972. Basalts and seafloor spreading behind the Mariana Island arc. Earth Planet. Sci. Lett., 15:12-18.

Hawkins, J.W., 1974. Geology of the Lau Basin, a marginal sea behind the Tonga Arc. In Burke, C., and Drake, C. (Eds.), Geology of Continental Margins: Berlin (Springer-Verlag), 505-520.

, 1976. Petrology and geochemistry of basaltic rocks of the Lau Basin. Earth Planet. Sci. Lett., 28:283-297.

1977. Petrologic and geochemical characteristics of marginal basin basalts. In Talwani, M., and Pitman, W.C., III (Eds.), Island Arcs, Deep Sea Trenches and Back-Arc Basins. Am. Geophys. Union, Maurice Ewing Ser., 1:355-365.

1988. Cruise Report-PAPATUA Expedition, Leg 04, R/V Thomas Washington. SIO Ref. Ser., 88-14.

1989. Cruise Report-ROUNDABOUT Expedition, Legs 14, 15, R/V Thomas Washington. SIO Ref. Ser., 89-13.

Hawkins, J.W., Bloomer, S.H., Evans, C.A., and Melchior, J.T., 1984. Evolution of intra-oceanic arc-trench systems. Tectonophysics, 102:175-205.

Hawkins, J.W., Lonsdale, P.F., Macdougall, J.D., and Volpe, A.M., 1990 Petrology of the axial ridge of the Mariana Trough backarc spreading center. Earth Planet. Sci. Lett., 100:226-256.

Hawkins, J.W., and Melchior, J.T., 1985. Petrology of Mariana Trough and Lau Basin basalts. J. Geophys. Res., 90:11431-11468.

Hawkins, J.W., Melchior, J., Florendo, F., and Nilsson, K., 1989. Evolution of backarc basin magmas and their mantle sources-examples from the Lau Basin and Mariana Trough. Eos, 70:1389.

Hawkins, J.W., Parson, L.M., Allan, J.F., and Leg 135 Scientific Party, 1991. New insight to the evolution of arc-backarc systems: results of Ocean Drilling Program (ODP) Leg 135, Lau-Tonga transect. Eos, 72:541.
Hochstaedter, A.G., Gill, J.B., Kusakabe, M., Newman, S., Pringle, M.S. Taylor, B., and Fryer, P., 1990. Volcanism in the Sumisu Rift. I. Major element, volatile and stable isotope geochemistry. Earth Planet. Sci. Lett., 100:179-194.

Hochstaedter, A.G., Gill, J.B., and Morris, J.D., 1990. Volcanism in the Sumisu Rift. II. Subduction and nonsubduction related components. Earth Planet. Sci. Lett., 100:195-209.

Isacks, B.L., and Barazangi, M., 1977. Geometry of Benioff zones: lateral segmentation and downwards bending of the subducted lithosphere. In Talwani, M., and Pitman, W.C., III (Eds.), Island Arcs, Deep Sea Trenches, and Back Arc Basins. Am. Geophys. Union, Maurice Ewing Ser., 1:94-114.

Jenner, G.A., Cawood, P.A., Rautenschlein, M., and White, W.M., 1987. Composition of back-arc basin volcanics, Valu Fa Ridge, Lau Basin: evidence for a slab-derived component in their mantle source. J. Volcanol. Geotherm. Res., 32:209-222.

Johnson, K.T.M., and Sinton, J.M., 1990. Petrology, tectonic setting, and the formation of back-arc basin basalts in the North Fiji Basin. Geol. Jahrb., 92:517-545.

Karig, D.E., 1970. Ridges and basins of the Tonga-Kermadec island arc system. J. Geophys. Res., 75:239-254.

Klein, E.M., and Langmuir, C.H., 1987. Global correlations of ocean ridge basalt chemistry with axial depth and crustal thickness. J. Geophys. Res. 92:8089-8115.

Korotev, R.L., 1987. National Bureau of Standards Coal Flyash (SRM1633a) as a multielement standard for instrumental neutron activation analysis. $J$. Radioanal. Nucl. Chem., 110:159-177.

Landsberger, S., 1986. Spectral interferences from uranium fission in neutron activation analysis. Chem. Geol., 57:415-421.

Landsberger, S., and Simsons, A., 1987. Quantification of uranium, thorium and gadolinium spectral interferences in instrumental neutron activation analysis of samarium. Chem. Geol., 62:223-226.

Lawver, L.A., and Hawkins, J.W., 1978. Diffuse magnetic anomalies in marginal basins: their possible tectonic and petrologic significance. Tectonophysics, 45:323-339.

Lawver, L.A., Hawkins, J.W., and Sclater, J.G., 1976. Magnetic anomalies and crustal dilation in the Lau Basin. Earth Planet. Sci. Lett., 33:27-35.

Loock, G., McDonough, W.F., Goldstein, S.L., and Hofmann, A.W., 1990. Isotopic compositions of volcanic glasses from the Lau Basin. Mar. Min., 9:235-245.

Louat, R., and Dupont, J., 1982. Seismicité de l'arc des Tonga-Kermadec. In Equipe de Geologie-Geophysique du Centre ORSTOM de Noumea. Contrib. à l'etude geodynamique du Sud-Ouest Pacifique, Trav. Doc. ORSTOM, 147:299-317.

Malahoff, A., Feden, R.H., and Fleming, H.S., 1982. Magnetic anomalies and tectonic fabric of marginal basins north of New Zealand. J. Geophys. Res., 87:4109-4125.

Masuda, A., Nakamura, N., and Tanaka, T., 1973. Fine structures of mutuallynormalized rare-earth patterns of chondrites. Geochim. Cosmochim. Acta., 37:239-248

Mattey, D.P., Marsh, N.G., and Tarney, J., 1981. The geochemistry, mineralogy, and petrology of basalts from the West Philippine and Parece Vela basins and from the Palau-Kyushu and West Mariana ridges, Deep Sea Drilling Project Leg 59. In Kroenke, L., Scott, R., et al., Init. Repts. DSDP 59: Washington (U.S. Govt. Printing Office), 753-800.

Melson, W.G., Vallier, T.L., Wright, T.L., Byerly, G., and Nelen, J., 1976. Chemical diversity of abyssal volcanic glass erupted along Pacific, Atlantic and Indian Ocean seafloor spreading centers. In Sutton, G.H., Manghani, M.H., and Moberly, R. (Eds.), The Geophysics of the Pacific Ocean Basin and Its Margin. Am. Geophys. Union, Monogr. Ser., 19:351-367.

Michael, P.J., and Chase, R.L., 1987. The influence of primary magma composition, $\mathrm{H}_{2} \mathrm{O}$, and pressure on mid-ocean ridge basalt differentiation. Contrib. Mineral. Petrol., 96:245-263.

Minster, J.B., and Jordan, T.H., 1978. Present-day plate motions. J. Geophys. Res., 83:5331-5354.

Nilsson, K., 1993. Oxidation state, sulfur speciation, and sulfur concentration in basaltic magmas: examples from Hess Deep and the Lau Basin [Ph.D. dissert.]. Univ, of California-San Diego.

Nilsson, K., Florendo, F., and Hawkins, J.W., 1989. Petrology of a nascent triple junction, northeastern Lau Basin. Eos, 73:1389.

Parson, L., Hawkins, J., Allan, J., et al., 1992. Proc. ODP, Init. Repts., 135: College Station, TX (Ocean Drilling Program).

Parson, L.M., et al., 1989. Charles Darwin Cruise 33/88, 5 May-1 June 1988. Geophysical surveying and geological sampling in the Lau back-arc basin, SW Pacific Ocean. Inst. Oceanogr. Sci. Deacon Lab. Cruise Rep., 206. 
Parson, L.M., Pearce, J.A., Murton, B.J., Hodkinson, R.A., Bloomer, S. Emewein, M., Huggett, Q.J., Miller, S., Johnson, L., Rodda, P., and Helu, S., 1990. Role of ridge jumps and ridge propagation in the tectonic evolution of the Lau back-arc basin, southwest Pacific. Geology, 18:470-473.

Pearce, J.A., and Cann, J.R., 1973. Tectonic setting of basic volcanic rocks determined using trace element analyses. Earth Planet. Sci. Lett., 19:290-300.

Pearce, J.A., Lippard, S.J., and Roberts, S., 1984. Characteristics and tectonic significance of supra-subduction zone ophiolites. In Kokelaar, B.P., and Howells, M.F. (Eds.), Marginal Basin Geology. Geol. Soc. Spec. Publ. London, 16:74-94.

Pearce, J.A., van der Laan, S.R., Arculus, R.J., Murton, B.J., Ishii, T., Peate, D.W., and Parkinson, I.J., 1992. Boninite and harzburgite from Leg 125 (Bonin-Mariana forearc): a case study of magma genesis during the initial stages of subduction. In Fryer, P., Pearce, J.A., Stokking, L.B., et al., Proc. ODP, Sci. Results, 125: College Station, TX (Ocean Drilling Program), 623-659.

Pelletier, B., and Louat, R., 1989. Seismotectonics and present day relative plate motions in the Tonga-Lau and Kermadec-Havre region. Tectonophysics, 165:237-250.

Perfit, M.R., Gust, D.A., Bence, A.E., Arculus, R.J., and Taylor, S.R., 1980 Chemical characteristics of island-arc basalts: implications for mantle sources. Chem. Geol., 30:227-256.

Poreda, R., 1985. Helium-3 and deuterium in back-arc basalts: Lau Basin and the Mariana Trough. Earth Planet. Sci. Lett., 73:244-254.

Sclater, J.G., Hawkins, J.W., Mammerickx, J., and Chase, C.G., 1972. Crustal extension between the Tonga and Lau Ridges: petrologic and geophysical evidence. Geol. Soc. Am. Bull., 83:505-518.

Sinton, J.M., and Fryer, P., 1987. Mariana Trough lavas from $18^{\circ} \mathrm{N}$ : implications for the origin of back arc basin basalts. J. Geophys. Res., 92:1278212802

Sinton, J.M., Wilson, D.S., Christie, D.M., Hey, R., and Delaney, J.R., 1983. Petrologic consequences of rift propagation on oceanic spreading ridges. Earth Planet. Sci. Lett., 62:193-207.

Sisson, T.W., and Grove, T.L., 1993a. Experimental investigations of the role of $\mathrm{H}_{2} \mathrm{O}$ in calk-alkaline differentiation and subduction zone magmatism. Contrib. Mineral. Petrol., 113:143-167.

, 1993b. Temperatures and $\mathrm{H}_{2} \mathrm{O}$ contents of low-MgO high-alumina basalts. Contrib. Mineral. Petrol., 113:167-184.

Sleep, N.H., and Toksöz, M.N., 1971. Evolution of marginal basins. Nature, 33:548-550.

Sun, S.-S., and McDonough, W.F., 1989. Chemical and isotopic systematics of oceanic basalts: implications for mantle composition and processes. In Saunders, A.D., and Norry, M.J. (Eds.), Magmatism in the Ocean Basins. Geol. Soc. Spec. Publ. London, 42:313-345.

Sunkel, G., 1990. Origin of petrological and geochemical variations of Lau Basin lavas (SW Pacific). Mar. Min., 9:205-234.

Takazawa, E., Frey, F.A., Shimizu, N., Obata, M., and Bodinier, J.L., 1992. Geochemical evidence for melt migration and reaction in the upper mantle. Nature, 359:55-58.

Tatsumi, Y., 1989. Migration of fluid phases and genesis of basalt magmas in subduction zones. J. Geophys. Res., 94:4697-4707.

Tatsumi, Y., Hamilton, D.L., and Nesbitt, R.W., 1986. Chemical characteristics of fluid phases from a subducted lithosphere and origin of arc magmas: evidence from high pressure experiments and natural rocks. J. Volcanol. Geotherm. Res., 29:293-309.

Toksöz, M.N., and Bird, P., 1977. Formation and evolution of marginal basins and continental plateaus. In Talwani, M., and Pitman, W.C., III (Eds.), Island Arcs, Deep Sea Trenches, and Back-arc Basins. Am. Geophys. Union, Maurice Ewing Ser., 1:379-393.

Ulmer, P., 1989. Partitioning of high field strength elements among olivine, pyroxenes, garnet and calc-alkaline picrobasalt; experimental results and an application. Ann. Rep., Director Geophys. Lab., Carnegie Inst. Washington, 1988-1989, 42-47.

Vallier, T.L., Jenner, G.A., Frey, F., Gill, J., Davis, A.S., Hawkins, J.W., Morris, J.D., Cawood, P.A., Morton, J., Scholl, D., Rautenschlein, M., White, W.M., Williams, R.W., Volpe, A.M., Stevenson, A.J., and White, L.D., 1991. Subalkaline andesite from Valu Fa Ridge, a back arc spreading center in southern Lau Basin: petrogenesis, comparative chemistry, and tectonic implication. Chem. Geol., 91:227-256.

Viereck, L.G., Flower, M.F.J., Hertogen, J., Schmincke, H.-U., and Jenner, G.A., 1989. The genesis and significance of N-MORB subtypes. Contrib. Mineral. Petrol., 102:112-126.

Volpe, A.M., Macdougall, J.D., and Hawkins, J.W., 1988. Lau Basin basalts (LBB): trace element and $\mathrm{Sr}-\mathrm{Nd}$ isotopic evidence for heterogeneity in backarc basin mantle. Earth Planet. Sci. Lett., 90:174-186.

Weissel, J.K., 1977. Evolution of the Lau Basin by the growth of small plates. In Talwani, M., and Pitman, W.C. (Eds.), Island Arcs, Deep Sea Trenches and Back Arc Basins. Am. Geophys. Union, Maurice Ewing Ser., 1:429-436.

Wharton, M.R., Hathaway, B., and Colley, H., 1992. Volcanism associated with extension in the Vitiaz island arc, Fiji. Symp. on Volcanism Associated with Extension at Consuming Plate Margins. Geol. Soc. London. (Abstract)

Whelan, P.M., Gill, J.B., Kollman, E., Duncan, R., and Drake, R.E., 1985. Radiometric dating of magmatic stages in Fiji. In Scholl, D.W., and Vallier, T.L. (Eds.), Geology and Offshore Resources of Pacific Island ArcsTonga Region. Circum-Pac. Counc. Energy Miner. Resour., Earth Sci. Ser., 2:415-440.

Wood, D.A., 1980. The application of a Th-Hf-Ta diagram to problems of tectonomagmatic classification and to establishing the nature of crustal contamination of basaltic lavas of the British Tertiary volcanic province. Earth Planet. Sci. Lett., 50:11-30.

Wood, D.A., Marsh, N.G., Tarney, J., Joron, L.J., Fryer, P., and Treuil, M., 1982. Geochemistry of igneous rocks recovered from a transect across the Mariana Trough, arc, forearc, and trench, Sites 453 through 461, Deep Sea Drilling Project Leg 60. In Hussong, D.M., Uyeda, S., et al., Init. Repts. DSDP, 60: Washington (U.S. Govt. Printing Office), 611-645.

Woodhall, D., 1985. Geology of the Lau Ridge. In Scholl, D.W., and Vallier, T.L. (Eds.), Geology and Offshore Resources of Pacific Island ArcsTonga Region. Circum-Pac. Counc. Energy Miner. Resour., Earth Sci. Ser., 2:351-378.

Date of initial receipt: 2 November 1992

Date of acceptance: 9 July 1993

Ms 135SR-136 
APPENDIX A

Major Element Microprobe Analyses of Leg 135 Glasses, Sites 834 through 839

\begin{tabular}{|c|c|c|c|c|c|c|c|c|c|c|c|c|c|c|}
\hline $\begin{array}{l}\text { Core, section, } \\
\text { interval }(\mathrm{cm})\end{array}$ & Unit & $\begin{array}{l}\text { Depth } \\
\text { (mbsf) }\end{array}$ & $\mathrm{SiO}_{2}$ & $\mathrm{TiO} 2$ & $\mathrm{Al}_{2} \mathrm{O}_{3}$ & $\mathrm{FeO}^{*}$ & $\mathrm{MnO}$ & $\mathrm{MgO}$ & $\mathrm{CaO}$ & $\mathrm{Na}_{2} \mathrm{O}$ & $\mathrm{K}_{2} \mathrm{O}$ & $\mathrm{P}_{2} \mathrm{O}_{5}$ & Sum & Mg\# \\
\hline $135-834 \mathrm{~A}-$ & & & & & & & & & & & & & & \\
\hline $12 X-C C, 2-4$ & 1 & 105.85 & 50.17 & 1.48 & 16.19 & 8.68 & 0.20 & 7.00 & 11.93 & 3.40 & 0.12 & 0.21 & 99.08 & 62.3 \\
\hline $12 \mathrm{X}-\mathrm{CC}, 20-22$ & $i$ & 106.03 & 50.62 & 1.47 & 16.55 & 8.73 & 0.19 & 6.74 & 11.80 & 3.37 & 0.14 & 0.13 & 99.73 & 61.3 \\
\hline $13 \mathrm{X}-1,18-24(\mathrm{~N})$ & 2 & 112.68 & 49.96 & 1.65 & 16.06 & 9.71 & 0.17 & 5.81 & 11.14 & 3.73 & 0.16 & 0.17 & 98.55 & 55.1 \\
\hline $14 \mathrm{X}-1,25-31(\mathrm{~N})$ & 2 & 117.25 & 50.87 & 1.54 & 15.68 & 10.00 & 0.19 & 5.42 & 10.73 & 3.33 & 0.21 & 0.18 & 98.16 & 52.6 \\
\hline $135-834 \mathrm{~B}-$ & & & & & & & & & & & & & & \\
\hline $15 \mathrm{R}-1,0-8(\mathrm{~N})$ & 6 & 175.40 & 50.55 & 1.27 & 16.11 & 8.86 & 0.16 & 6.30 & 11.78 & 2.76 & 0.20 & 0.13 & 98.06 & 59.3 \\
\hline $15 \mathrm{R}-1,43-50$ & 6 & 175.83 & 52.38 & 1.90 & 15.82 & 10.09 & 0.19 & 5.30 & 9.95 & 3.55 & 0.17 & 0.18 & 99.55 & 51.8 \\
\hline $15 \mathrm{R}-2,35-37$ & 6 & 177.15 & 51.87 & 1.86 & 15.62 & 9.97 & 0.21 & 5.29 & 9.97 & 3.62 & 0.19 & 0.23 & 98.89 & 52.1 \\
\hline 15R-2, 35-37 REP & 6 & 177.15 & 52.05 & 1.86 & 15.64 & 9.94 & 0.18 & 5.28 & 9.89 & 3.60 & 0.17 & 0.20 & 98.81 & 52.1 \\
\hline $15 R-2,56-62$ & 6 & 177.36 & 52.06 & 1.94 & 15.71 & 10.12 & 0.18 & 5.24 & 9.89 & 3.75 & 0.19 & 0.23 & 99.29 & 51.5 \\
\hline $15 R-2,56-62$ & 6 & 177.36 & 52.07 & 1.87 & 15.65 & 9.99 & 0.19 & 5.18 & 9.83 & 3.68 & 0.18 & 0.22 & 98.86 & 51.5 \\
\hline $16 \mathrm{R}-1,45-51$ & 6 & 185.45 & 54.83 & 2.42 & 15.29 & 11.05 & 0.24 & 3.65 & 7.45 & 3.09 & 0.32 & 0.45 & 98.78 & 40.4 \\
\hline $18 \mathrm{R}-1,0-6(\mathrm{~N})$ & 6 & 204.00 & 51.28 & 1.30 & 16.29 & 8.29 & 0.18 & 6.31 & 10.98 & 3.17 & 0.19 & 0.15 & 98.14 & 60.9 \\
\hline $18 \mathrm{R}-1,7-12$ & 6 & 204.07 & 51.81 & 1.35 & 16.54 & 8.43 & 0.19 & 6.53 & 10.81 & 3.14 & 0.18 & 0.1 & 99.10 & 61.4 \\
\hline $18 \mathrm{R}-1,14-21$ & 6 & 204.14 & 51.58 & 1.33 & 16.42 & 8.54 & 0.19 & 6.47 & 10.58 & 3.27 & 0.16 & 0.2 & 98.75 & 60.8 \\
\hline $18 \mathrm{R}-1,14-21$ & 6 & 204.14 & 51.76 & 1.39 & 16.55 & 8.37 & 0.17 & 6.46 & 10.70 & 3.03 & 0.18 & 0.16 & 98.77 & 61.3 \\
\hline $19 \mathrm{R}-1,5-10(\mathrm{~N})$ & 6 & 208.85 & 51.47 & 1.37 & 16.44 & 8.38 & 0.15 & 5.96 & 10.98 & 3.21 & 0.17 & 0.14 & 98.25 & 59.3 \\
\hline Mean, Unit 6 (12) & & & 51.98 & 1.66 & 16.01 & 9.34 & 0.19 & 5.66 & 10.23 & 3.32 & 0.19 & 0.2 & 98.77 & 55.2 \\
\hline $22 \mathrm{R}-1,41-46(\mathrm{~N})$ & 7 & 223.61 & 49.82 & 1.31 & 16.53 & 8.87 & 0.18 & 8.24 & 11.64 & 3.29 & 0.06 & 0.14 & 100.13 & 64.1 \\
\hline $26 \mathrm{R}-1,30-34$ & 7 & 242.90 & 50.21 & 1.40 & 16.17 & 8.82 & 0.20 & 7.65 & 11.79 & 2.96 & 0.08 & 0.13 & 99.41 & 64.0 \\
\hline 26R-1, 30-34 REP & 7 & 242.90 & 49.91 & 1.35 & 16.27 & 8.64 & 0.17 & 7.59 & 11.72 & 3.08 & 0.08 & 0.13 & 98.92 & 64.3 \\
\hline $26 \mathrm{R}-1,30-34 \mathrm{REP}$ & 7 & 242.90 & 50.49 & 1.36 & 16.22 & 8.88 & 0.18 & 7.63 & 11.55 & 3.00 & 0.08 & 0.12 & 99.51 & 63.8 \\
\hline $27 \mathrm{R}-1,29-32$ & 7 & 248.00 & 52.80 & 0.71 & 16.18 & 8.46 & 0.19 & 6.56 & 11.57 & 1.80 & 0.32 & 0.08 & 98.67 & 61.4 \\
\hline $29 \mathrm{R}-1,7-12$ & 7 & 257.37 & 50.17 & 1.42 & 16.33 & 8.67 & 0.20 & 7.73 & 11.87 & 3.08 & 0.09 & 0.11 & 99.65 & 64.6 \\
\hline $30 \mathrm{R}-1,58-60$ & 7 & 262.48 & 50.11 & 1.37 & 16.18 & 8.82 & 0.15 & 7.74 & 12.10 & 2.92 & 0.09 & 0.10 & 99.58 & 64.3 \\
\hline $30 \mathrm{R}-1,107-112$ & 7 & 265.90 & 50.13 & 1.41 & 16.14 & 8.72 & 0.16 & 7.70 & 12.21 & 2.96 & 0.09 & 0.12 & 99.63 & 64.4 \\
\hline $30 \mathrm{R}-1,112-120$ & 7 & 265.96 & 50.57 & 1.37 & 16.33 & 8.75 & 0.21 & 7.73 & 12.04 & 3.02 & 0.10 & 0.13 & 100.25 & 64.4 \\
\hline $30 \mathrm{R}-2,98-104$ & 7 & 264.32 & 50.65 & 1.38 & 16.26 & 8.75 & 0.19 & 7.71 & 11.96 & 3.05 & 0.09 & 0.14 & 100.17 & 64.4 \\
\hline $30 \mathrm{R}-2,98-104(\mathrm{~N})$ & 7 & 264.32 & 50.23 & 1.36 & 16.23 & 8.57 & 0.15 & 7.70 & 12.13 & 3.01 & 0.09 & 0.11 & 99.57 & 64.8 \\
\hline $31 \mathrm{R}-2,37-42(\mathrm{~N})$ & 7 & 268.68 & 49.96 & 1.40 & 16.19 & 8.83 & 0.16 & 7.54 & 11.96 & 2.96 & 0.09 & 0.12 & 99.22 & 63.6 \\
\hline $31 \mathrm{R}-2,43-48$ & 7 & 269.00 & 50.33 & 1.33 & 16.24 & 8.75 & 0.20 & 7.71 & 11.98 & 3.07 & 0.08 & 0.18 & 99.87 & 64.4 \\
\hline $31 \mathrm{R}-1,98-104$ & 7 & 267.88 & 50.23 & 1.36 & 16.46 & 8.87 & 0.12 & 8.20 & 11.95 & 3.33 & 0.09 & 0.14 & 100.79 & 64.4 \\
\hline $32 \mathrm{R}-1,0-5$ & 7 & 271.50 & 48.95 & 1.31 & 16.84 & 9.10 & 0.15 & 8.15 & 11.71 & 3.31 & 0.08 & 0.09 & 99.75 & 64.7 \\
\hline $32 \mathrm{R}-1,0-5(\mathrm{~N})$ & 7 & 271.50 & 48.95 & 1.31 & 16.84 & 9.10 & 0.15 & 8.15 & 11.71 & 3.31 & 0.08 & 0.09 & 99.75 & 64.5 \\
\hline $33 \mathrm{R}-1,0-6$ & 7 & 281.20 & 49.82 & 1.36 & 16.18 & 8.72 & 0.15 & 7.61 & 12.00 & 2.92 & 0.09 & 0.12 & 98.96 & 64.1 \\
\hline Mean, Unit 7 (17) & & & 50.20 & 1.32 & 16.33 & 8.78 & 0.17 & 7.73 & 11.88 & 3.00 & 0.10 & 0.12 & 99.64 & 64.1 \\
\hline $35 \mathrm{R}-1,31-37(\mathrm{~N})$ & 8 & 291.11 & 51.67 & 1.21 & 15.79 & 8.90 & 0.17 & 5.90 & 10.83 & 2.90 & 0.10 & 0.13 & 97.60 & 57.6 \\
\hline $35 \mathrm{R}-2,67-69(\mathrm{~N})$ & 8 & 292.72 & 51.28 & 1.21 & 15.75 & 8.75 & 0.18 & 6.00 & 11.08 & 2.88 & 0.11 & 0.12 & 97.37 & 58.4 \\
\hline $35 \mathrm{R}-2,77-83$ & 8 & 292.82 & 51.79 & 1.22 & 16.16 & 8.83 & 0.18 & 5.94 & 11.19 & 2.86 & 0.11 & 0.11 & 98.38 & 58.0 \\
\hline $35 \mathrm{R}-2,96-101$ & 8 & 293.01 & 51.55 & 1.21 & 16.25 & 8.57 & 0.18 & 5.96 & 11.16 & 2.89 & 0.11 & 0.10 & 97.98 & 58 \\
\hline $36 \mathrm{R}-1,7-10(\mathrm{~N})$ & 8 & 300.57 & 51.66 & 1.27 & 16.00 & 8.81 & 0.18 & 6.06 & 11.61 & 2.82 & 0.11 & 0.10 & 98.61 & 58.5 \\
\hline Mean, Unit 8 (5) & & & 51.59 & 1.22 & 15.99 & 8.77 & 0.18 & 5.97 & 11.17 & 2.87 & 0.11 & 0.11 & $\begin{array}{l}97.01 \\
97.99\end{array}$ & 58.3 \\
\hline $37 \mathrm{R}-2,42-44$ & $10 \mathrm{~A}$ & 311.87 & 55.43 & 1.91 & 15.34 & 10.26 & 0.21 & 3.93 & 7.73 & 3.21 & 0.30 & 0.25 & 98.59 & 44.0 \\
\hline $37 \mathrm{R}-2,42-44$ REP & $10 \mathrm{~A}$ & 311.87 & 55.51 & 1.94 & 15.24 & 10.18 & 0.19 & 3.86 & 7.55 & 2.82 & 0.26 & 0.26 & 97.80 & 43.7 \\
\hline $37 \mathrm{R}-2,42-44$ REP & $10 \mathrm{~A}$ & 311.87 & 55.91 & 1.99 & 15.27 & 10.30 & 0.23 & 3.87 & 7.63 & 3.33 & 0.28 & 0.28 & 99.05 & 43.5 \\
\hline $39 \mathrm{R}-1,0-7(\mathrm{~N})$ & $10 \mathrm{~A}$ & 324.80 & 51.88 & 1.77 & 14.96 & 10.98 & 0.24 & 4.62 & 9.51 & 3.31 & 0.26 & 0.19 & 97.71 & 46.3 \\
\hline $40 \mathrm{R}-1,0-4$ & $10 \mathrm{~A}$ & 329.40 & 52.64 & 1.68 & 15.20 & 11.01 & 0.22 & 4.72 & 9.53 & 3.18 & 0.29 & 0.17 & 98.64 & 46.8 \\
\hline $40 \mathrm{R}-1,44-47$ & $10 \mathrm{~A}$ & 329.84 & 52.66 & 1.71 & 15.19 & 11.14 & 0.24 & 4.55 & 9.16 & 3.42 & 0.26 & 0.19 & 98.53 & 45.6 \\
\hline $41 \mathrm{R}-1,0-5$ & $10 \mathrm{~A}$ & 334.80 & 52.66 & 1.75 & 15.26 & 11.28 & 0.20 & 4.51 & 9.22 & 2.95 & 0.29 & 0.19 & 98.29 & 45.0 \\
\hline $41 \mathrm{R}-1,6-12$ & $10 \mathrm{~A}$ & 334.46 & 51.94 & 1.79 & 15.28 & 11.07 & 0.22 & 4.48 & 9.08 & 3.30 & 0.26 & 0.20 & 97.62 & 45.3 \\
\hline $42 \mathrm{R}-1,0-5$ & $10 \mathrm{~A}$ & 339.10 & 51.56 & 1.70 & 15.75 & 10.44 & 0.20 & 5.10 & 9.81 & 3.44 & 0.19 & 0.17 & 98.36 & 50.0 \\
\hline Mean, Unit 10A (9) & & & 53.35 & 1.80 & 15.28 & 10.74 & 0.22 & 4.40 & 8.80 & 3.22 & 0.27 & 0.21 & 98.29 & 45.6 \\
\hline $46 \mathrm{R}-1,37-40$ & 11 & 358.87 & 50.53 & 1.18 & 16.16 & 8.77 & 0.17 & 6.63 & 12.00 & 2.77 & 0.12 & 0.12 & 98.46 & 60.8 \\
\hline $46 \mathrm{R}-1,37-40$ REP & 11 & 358.87 & 50.43 & 1.36 & 16.34 & 8.71 & 0.17 & 7.64 & 11.73 & 3.07 & 0.08 & 0.12 & 99.66 & 64.3 \\
\hline $47 \mathrm{R}-1,130-135$ & 12 & 364.80 & 50.85 & 1.35 & 16.00 & 9.17 & 0.17 & 6.08 & 11.36 & 2.99 & 0.14 & 0.14 & 98.26 & 57.6 \\
\hline $47 \mathrm{R}-1,130-135$ REP & 12 & 364.80 & 56.15 & 2.13 & 14.84 & 12.39 & 0.23 & 3.16 & 7.28 & 2.34 & 0.24 & 0.25 & 99.00 & 34.3 \\
\hline $50 \mathrm{R}-1,87-92$ & 12 & 392.87 & 55.50 & 2.10 & 14.54 & 12.56 & 0.26 & 3.21 & 7.28 & 2.19 & 0.22 & 0.25 & 98.11 & 34.4 \\
\hline S1R-1, 10-15 & 12 & 401.60 & 55.22 & 2.14 & 14.39 & 12.58 & 0.22 & 3.16 & 7.38 & 2.58 & 0.23 & 0.27 & 98.18 & 34.0 \\
\hline $54 \mathrm{R}-1,5-10(\mathrm{~N})$ & 12 & 387.90 & 54.06 & 2.15 & 14.69 & 12.97 & 0.19 & 3.59 & 7.42 & 3.42 & 0.22 & 0.24 & 98.94 & 36.3 \\
\hline $54 \mathrm{R}-1,05-10$ & 12 & 387.90 & 55.05 & 2.13 & 14.66 & 12.78 & 0.28 & 3.39 & 7.35 & 2.62 & 0.23 & 0.27 & 98.76 & 35.2 \\
\hline Mean, Unit $12(6)$ & & & 55.20 & 2.13 & 14.62 & 12.66 & 0.24 & 3.30 & 7.34 & 2.63 & 0.23 & 0.26 & 98.60 & 34.8 \\
\hline $57 \mathrm{R}-1,0-5$ & 13 & 414.79 & 54.74 & 2.11 & 14.61 & 12.51 & 0.26 & 3.41 & 7.53 & 2.95 & 0.20 & 0.27 & 98.58 & 35.8 \\
\hline $57 \mathrm{R}-1,34-40$ & 13 & 415.13 & 50.72 & 1.30 & 16.07 & 9.12 & 0.18 & 6.16 & 11.41 & 2.90 & 0.14 & 0.12 & 98.13 & 58.1 \\
\hline $57 \mathrm{R}-1,34-40(\mathrm{~N})$ & 13 & 415.13 & 50.70 & 1.27 & 16.11 & 9.44 & 0.15 & 6.56 & 11.21 & 3.22 & 0.12 & 0.09 & 98.87 & 57 \\
\hline $59 \mathrm{R}-2,30-32$ & 13 & 432.73 & 50.98 & 1.34 & 15.93 & 9.29 & 0.20 & 5.97 & 11.16 & 3.03 & 0.14 & 0.14 & 98.19 & 56.8 \\
\hline $59 \mathrm{R}-2,52-55$ & 13 & 432.95 & 51.18 & 1.33 & 16.14 & 9.08 & 0.19 & 6.10 & 11.41 & 2.98 & 0.14 & 0.10 & 98.66 & 57.9 \\
\hline 59R-2, 52-55 REP & 13 & 432.95 & 50.92 & 1.33 & 16.06 & 9.16 & 0.19 & 6.09 & 11.39 & 2.98 & 0.15 & 0.16 & 98.44 & 57.7 \\
\hline Mean, Unit $13(6)$ & & & 51.54 & 1.45 & 15.82 & 9.77 & 0.20 & 5.72 & 10.69 & 3.01 & 0.15 & 0.15 & 98.48 & 54.0 \\
\hline $35-835 \mathrm{~B}-$ & & & & & & & & & & & & & & \\
\hline $3 R-2,0-4$ & & 155.74 & 52.05 & 1.10 & 15.81 & 10.04 & 0.20 & 6.17 & 11.46 & 2.41 & 0.20 & 0.11 & 99.55 & 55.7 \\
\hline $3 R-2,0-4$ REP & 1 & 155.74 & 52.05 & 1.10 & 15.81 & 10.04 & 0.20 & 6.17 & 11.46 & 2.41 & 0.20 & 0.11 & 99.55 & 55.7 \\
\hline $3 R-2,4-5$ & $i$ & 156.00 & 52.28 & 1.07 & 15.49 & 9.92 & 0.19 & 6.14 & 11.09 & 2.40 & 0.20 & 0.12 & 98.89 & 55.9 \\
\hline $3 \mathrm{R}-2,4-5$ REP & 1 & 156.00 & 52.28 & 1.07 & 15.49 & 9.92 & 0.19 & 6.14 & 11.09 & 2.40 & 0.20 & 0.12 & 98.89 & 55.9 \\
\hline $4 \mathrm{R}-1,67-73$ & $i$ & 164.67 & 51.82 & 1.05 & 15.56 & 10.03 & 0.20 & 6.10 & 11.39 & 2.34 & 0.21 & 0.12 & 98.80 & 55.5 \\
\hline $4 \mathrm{R}-1,79-85$ & 1 & 164.79 & 51.90 & 1.11 & 15.48 & 10.02 & 0.20 & 6.12 & 11.05 & 2.41 & 0.25 & 0.10 & 98.63 & 55.6 \\
\hline $4 \mathrm{R}-1,79-85$ REP & 1 & 164.79 & 51.65 & 1.08 & 15.37 & 9.91 & 0.18 & 6.12 & 11.04 & 2.33 & 0.20 & 0.11 & 98.00 & 55.9 \\
\hline $4 \mathrm{R}-1,79-85 \mathrm{REP}$ & $i$ & 164.79 & 52.38 & 1.11 & 15.45 & 10.21 & 0.17 & 6.11 & 11.25 & 2.40 & 0.21 & 0.15 & 99.44 & 55.1 \\
\hline $4 \mathrm{R}-1,79-85 \mathrm{REP}$ & 1 & 164.79 & 52.38 & 1.11 & 15.45 & 10.21 & 0.17 & 6.11 & 11.25 & 2.40 & 0.21 & 0.15 & 99.44 & 55.1 \\
\hline $4 \mathrm{R}-1,115-120$ & 1 & 165.15 & 51.90 & 1.06 & 15.40 & 9.79 & 0.18 & 6.11 & 11.10 & 2.34 & 0.21 & 0.11 & 98.20 & 56.1 \\
\hline $4 \mathrm{R}-1,115-120 \mathrm{REP}$ & $i$ & 165.15 & 52.37 & 1.05 & 15.56 & 9.91 & 0.19 & 6.08 & 10.96 & 2.19 & 0.20 & 0.12 & 98.62 & 55.7 \\
\hline $4 \mathrm{R}-1,115-120 \mathrm{REP}$ & 1 & 165.15 & 52.37 & 1.05 & 15.56 & 9.91 & 0.19 & 6.08 & 10.96 & 2.19 & 0.20 & 0.12 & 98.62 & 55.7 \\
\hline $4 \mathrm{R}-1,115-120 \mathrm{REP}$ & 1 & 165.15 & 51.90 & 1.06 & 15.40 & 9.79 & 0.18 & 6.11 & 11.1 & 2.34 & 0.21 & 0.11 & 98.2 & 56.1 \\
\hline
\end{tabular}


APPENDIX A (continued).

\begin{tabular}{|c|c|c|c|c|c|c|c|c|c|c|c|c|c|c|c|c|c|}
\hline $\begin{array}{l}\text { Core, section, } \\
\text { interval }(\mathrm{cm})\end{array}$ & Unit & $\begin{array}{l}\text { Depth } \\
\text { (mbsf) }\end{array}$ & $\mathrm{SiO}_{2}$ & $\mathrm{TiO} 2$ & $\mathrm{Al}_{2} \mathrm{O}_{3}$ & $\mathrm{FeO}^{*}$ & $\mathrm{MnO}$ & $\mathrm{MgO}$ & $\mathrm{CaO}$ & $\mathrm{Na}_{2} \mathrm{O}$ & $\mathrm{K}_{2} \mathrm{O}$ & $\mathrm{P}_{2} \mathrm{O}_{5}$ & Sum & Mg\# & $\mathrm{CaO} / \mathrm{Al}_{2} \mathrm{O}_{3}$ & $\begin{array}{c}\mathrm{Na}_{2} \mathrm{O} / \\
\left(\mathrm{Na}_{2} \mathrm{O} / \mathrm{CaO}\right)\end{array}$ & $\mathrm{Na}_{2} \mathrm{O} 8$ \\
\hline $4 \mathrm{R}-1,127-133$ & 1 & 165.27 & 51.89 & 1.06 & 15.40 & 9.83 & 0.20 & 6.07 & 10.82 & 2.31 & 0.21 & 0.12 & 97.91 & 55.9 & 0.703 & 0.213 & 1.59 \\
\hline $4 \mathrm{R}-1,127-133$ REP & 1 & 165.27 & 51.89 & 1.06 & 15.40 & 9.83 & 0.20 & 6.07 & 10.82 & 2.31 & 0.21 & 0.12 & 97.91 & 55.9 & 0.703 & 0.213 & 1.59 \\
\hline $4 \mathrm{R}-1,134-141$ & 1 & 165.34 & 51.66 & 1.07 & 15.74 & 10.15 & 0.19 & 6.09 & 11.28 & 2.30 & 0.20 & 0.11 & 98.78 & 55.2 & 0.717 & 0.204 & 1.59 \\
\hline 4R-1, 134-141 REP & 1 & 165.34 & 52.02 & 1.10 & 15.47 & 10.07 & 0.20 & 6.20 & 11.13 & 2.34 & 0.19 & 0.10 & 98.82 & 55.8 & 0.719 & 0.210 & 1.67 \\
\hline $4 \mathrm{R}-1,134-141$ REP & 1 & 165.34 & 52.11 & 1.05 & 15.47 & 10.04 & 0.19 & 6.10 & 11.11 & 2.38 & 0.19 & 0.13 & 98.77 & 55.5 & 0.718 & 0.214 & 1.68 \\
\hline $4 \mathrm{R}-1,134-141$ REP & 1 & 165.34 & 51.66 & 1.07 & 15.74 & 10.15 & 0.19 & 6.09 & 11.28 & 2.30 & 0.20 & 0.11 & 98.78 & 55.2 & 0.717 & 0.204 & 1.59 \\
\hline 4R-1, 134-141 REP & 1 & 165.34 & 52.02 & 1.10 & 15.47 & 10.07 & 0.20 & 6.20 & 11.13 & 2.34 & 0.19 & 0.10 & 98.82 & 55.8 & 0.719 & 0.210 & 1.67 \\
\hline $5 R-1,14-21$ & 1 & 169.14 & 52.34 & 1.08 & 15.44 & 9.93 & 0.20 & 6.16 & 11.29 & 2.39 & 0.20 & 0.12 & 99.16 & 56.0 & 0.731 & 0.212 & 1.71 \\
\hline $6 \mathrm{R}-1,9-14$ & 1 & 174.50 & 51.96 & 1.11 & 15.62 & 10.10 & 0.20 & 6.01 & 11.02 & 2.32 & 0.23 & 0.13 & 98.69 & 54.9 & 0.706 & 0.211 & 1.58 \\
\hline 6R-1,9-14 REP & 1 & 173.79 & 52.45 & 1.08 & 15.51 & 10.06 & 0.19 & 6.15 & 11.04 & 2.37 & 0.21 & 0.08 & 99.13 & 55.6 & 0.712 & 0.215 & 1.68 \\
\hline 6R-1,9-14 REP & 1 & 174.50 & 52.45 & 1.08 & 15.51 & 10.06 & 0.19 & 6.15 & 11.04 & 2.37 & 0.21 & 0.08 & 99.13 & 55.6 & 0.712 & 0.215 & 1.68 \\
\hline 6R-1,9-14 REP & 1 & 173.79 & 51.96 & 1.11 & 15.62 & 10.10 & 0.20 & 6.01 & 11.02 & 2.32 & 0.23 & 0.13 & 98.69 & 54.9 & 0.706 & 0.211 & 1.58 \\
\hline $7 \mathrm{R}-3,137-140$ & 1 & 185.00 & 51.76 & 1.08 & 15.46 & 9.77 & 0.18 & 6.15 & 11.25 & 2.44 & 0.19 & 0.13 & 98.41 & 56.3 & 0.728 & 0.217 & 1.75 \\
\hline 7R-3, 137-140 REP & $i$ & 185.00 & 51.76 & 1.08 & 15,46 & 9.77 & 0.18 & 6.15 & 11.25 & 2.44 & 0.19 & 0.13 & 98.41 & 56.3 & 0.728 & 0.217 & 1.75 \\
\hline Mean, Unit 1 (27) & & & 52.05 & 1.08 & 15.52 & 9.99 & 0.19 & 6.12 & 11.14 & 2.35 & 0.21 & 0.12 & 98.75 & 55.7 & 0.710 & 0.210 & 1.65 \\
\hline \multicolumn{18}{|l|}{$135-836 \mathrm{~A}-$} \\
\hline $3 \mathrm{H}-2,83-85$ & 1 & 13.03 & 50.08 & 1.40 & 16.21 & 8.45 & 0.18 & 7.61 & 11.92 & 3.09 & 0.09 & 0.12 & 99.16 & 64.9 & 0.735 & 0.259 & 1.98 \\
\hline $3 \mathrm{H}-7,54-55$ & 3 & 20.12 & 49.21 & 0.90 & 15.64 & 8.91 & 0.18 & 7.84 & 13.59 & 2.04 & 0.06 & 0.07 & 98.43 & 64.3 & 0.869 & 0.150 & 2.95 \\
\hline $4 \mathrm{H}-\mathrm{CC}, 0-13$ & 3 & 20.20 & 49.62 & 0.86 & 15.78 & 9.11 & 0.18 & 7.88 & 13.91 & 2.06 & 0.06 & 0.06 & 99.53 & 63.9 & 0.881 & 0.148 & 2.02 \\
\hline $4 \mathrm{H}-\mathrm{CC}, 0-13 \mathrm{REP}$ & 3 & 20.20 & 49.76 & 0.89 & 15.81 & 9.32 & 0.19 & 7.94 & 13.79 & 2.05 & 0.06 & 0.07 & 99.88 & 63.6 & 0.872 & 0.149 & 2.03 \\
\hline Mean, Unit 3 (3) & & & 49.53 & 0.88 & 15.74 & 9.11 & 0.18 & 7.89 & 13.76 & 2.05 & 0.06 & 0.07 & 99.28 & 64.0 & 0.870 & 0.150 & 2.33 \\
\hline $7 X-1,8-14$ & 4 & 25.78 & 50.06 & 0.89 & 16.00 & 8.82 & 0.21 & 7.96 & 13.68 & 2.06 & 0.07 & 0.08 & 99.84 & 64.9 & 0.855 & 0.151 & 2.05 \\
\hline $7 X-1,15-22$ & 4 & 25.85 & 49.48 & 0.85 & 15.60 & 9.00 & 0.18 & 7.86 & 13.52 & 2.07 & 0.06 & 0.06 & 98.69 & 64.2 & 0.867 & 0.153 & 2.02 \\
\hline Mean, Unit 4 (2) & & & 49.77 & 0.87 & 15.80 & 8.91 & 7.91 & 13.60 & 2.07 & 0.07 & 0.07 & & 99.27 & 64.6 & 0.860 & 0.150 & 2.04 \\
\hline \multicolumn{18}{|l|}{$135-836 \mathrm{~B}-$} \\
\hline $7 R-2,56-62$ & 5 & 45.76 & 52.81 & 1.18 & 14.88 & 11.56 & 0.22 & 5.36 & 9.91 & 2.35 & 0.23 & 0.13 & 98.63 & 48.7 & 0.666 & 0.237 & 1.37 \\
\hline $7 R-2,56-62$ REP & 5 & 45.76 & 52.80 & 1.20 & 15.08 & 11.32 & 0.23 & 5.49 & 10.22 & 2.42 & 0.26 & 0.12 & 99.13 & 49.9 & 0.678 & 0.237 & 1.49 \\
\hline $7 \mathrm{R}-2,56-62$ REP & 5 & 45.76 & 52.81 & 1.18 & 14.88 & 11.56 & 0.22 & 5.36 & 9.91 & 2.35 & 0.23 & 0.13 & 98.63 & 48.7 & 0.666 & 0.237 & 1.37 \\
\hline $9 \mathrm{M}-1,97-102$ & $5 ?$ & 46.00 & 52.79 & 1.17 & 14.94 & 11.31 & 0.23 & 5.54 & 10.31 & 2.33 & 0.23 & 0.12 & 98.97 & 50.1 & 0.690 & 0.226 & 1.42 \\
\hline $9 \mathrm{M}-1,97-102$ REP & $5 ?$ & 46.00 & 52.62 & 1.16 & 14.86 & 11.45 & 0.20 & 5.47 & 10.20 & 2.33 & 0.23 & 0.12 & 98.65 & 49.5 & 0.686 & 0.228 & 1.39 \\
\hline Mean, Unit 5 (5) & & & 52.77 & 1.18 & 14.93 & 11.44 & 0.22 & 5.44 & 10.11 & 2.36 & 0.24 & 0.12 & 98.80 & 49.4 & 0.680 & 0.230 & 1.41 \\
\hline \multicolumn{18}{|l|}{$135-838 \mathrm{~A}-$} \\
\hline $9 \mathrm{H}-2,95-117 \mathrm{~A}$ & 1 & 72.65 & 52.95 & 0.92 & 15.00 & 11.19 & 0.23 & 5.64 & 10.72 & 1.93 & 0.35 & 0.09 & 99.01 & 50.8 & 0.715 & 0.180 & 1.05 \\
\hline $9 \mathrm{H}-2,95-117 \mathrm{~B}$ & 1 & 72.65 & 52.64 & 0.90 & 16.02 & 10.64 & 0.19 & 5.91 & 9.84 & 2.02 & 0.35 & 0.10 & 98.61 & 53.2 & 0.614 & 0.205 & 1.24 \\
\hline $9 \mathrm{H}-2,95-117 \mathrm{C}$ & i & 72.65 & 53.08 & 0.91 & 14.65 & 10.76 & 0.18 & 5.96 & 9.98 & 2.01 & 0.36 & 0.11 & 98.01 & 53.2 & 0.681 & 0.201 & 1.25 \\
\hline $9 \mathrm{H}-2,95-117 \mathrm{D}$ & 1 & 72.65 & 52.18 & 0.90 & 17.39 & 10.52 & 0.20 & 5.87 & 9.69 & 2.04 & 0.33 & 0.09 & 99.22 & 53.4 & 0.557 & 0.211 & 1.25 \\
\hline $9 \mathrm{H}-2,95-117 \mathrm{EC}$ & 1 & 72.65 & 52.74 & 0.91 & 15.12 & 11.30 & 0.25 & 5.58 & 11.13 & 1.92 & 0.30 & 0.08 & 99.32 & 50.3 & 0.740 & 0.173 & 1.02 \\
\hline Mean, Unit 1 mafic & & & 52.72 & 0.91 & 15.64 & 10.88 & 0.21 & 5.79 & 10.27 & 1.98 & 0.34 & 0.09 & 98.83 & 52.2 & 0.660 & 0.190 & 1.16 \\
\hline \multicolumn{18}{|l|}{$135-838 \mathrm{~B}-$} \\
\hline $4 \mathrm{R}-1,0-6 \mathrm{~A}$ & 1 & 163.20 & 72.88 & 0.86 & 14.07 & 4.08 & 0.11 & 0.14 & 3.80 & 3.04 & 0.59 & 0.21 & 99.78 & 6.6 & 0.270 & 0.800 & ND \\
\hline $4 \mathrm{R}-1,0-6 \mathrm{~B}$ & $i$ & 163.20 & 68.98 & 0.64 & 16.96 & 3.11 & 0.12 & 0.14 & 5.11 & 4.40 & 0.39 & 0.12 & 99.96 & 8.4 & 0.300 & 0.861 & ND \\
\hline $18 \mathrm{R}-1,6-8$ & 2 & 266.46 & 55.84 & 1.10 & 14.90 & 10.94 & 0.24 & 4.10 & 8.77 & 2.30 & 0.49 & 0.16 & 98.83 & 43.4 & 0.589 & 0.262 & 0.85 \\
\hline $19 \mathrm{R}-1,64-69$ & 3 & 276.64 & 52.71 & 0.71 & 16.20 & 8.61 & 0.16 & 6.29 & 11.93 & 1.85 & 0.31 & 0.10 & 98.89 & 60.0 & 0.736 & 0.155 & 1.22 \\
\hline $20 \mathrm{R}-1,36-41$ & 3 & 286.06 & 52.78 & 0.70 & 16.04 & 8.58 & 0.18 & 6.39 & 12.02 & 1.77 & 0.31 & 0.10 & 98.89 & 60.4 & 0.749 & 0.147 & 1.17 \\
\hline $22 \mathrm{R}-1,19-23$ & 3 & 305.25 & 53.21 & 0.70 & 15.90 & 8.71 & 0.17 & 6.43 & 12.24 & 1.80 & 0.32 & 0.09 & 99.57 & 60.2 & 0.770 & 0.147 & 1.22 \\
\hline $22 \mathrm{R}-1,24-29$ & 3 & 305.25 & 52.48 & 0.69 & 15.63 & 8.52 & 0.16 & 6.59 & 12.19 & 1.72 & 0.31 & 0.08 & 98.36 & 61.3 & 0.780 & 0.141 & 1.20 \\
\hline $23 \mathrm{R}-1,28-31$ & 3 & 314.88 & 52.59 & 0.69 & 15.52 & 8.42 & 0.19 & 6.60 & 12.32 & 1.73 & 0.30 & 0.10 & 98.46 & 61.6 & 0.794 & 0.140 & 1.21 \\
\hline $23 \mathrm{R}-1,40-44$ & 3 & 315.00 & 52.29 & 0.70 & 16.00 & 8.60 & 0.20 & 6.34 & 12.14 & 1.78 & 0.32 & 0.12 & 98.48 & 60.6 & 0.759 & 0.150 & 1.16 \\
\hline $25 \mathrm{R}-1,11-16$ & 3 & 334.11 & 52.14 & 0.69 & 15.48 & 8.54 & 0.18 & 6.65 & 12.47 & 1.75 & 0.30 & 0.08 & 98.27 & 61.5 & 0.806 & 0.140 & 1.25 \\
\hline Mean, Unit 3 (7) & & & 52.60 & 0.70 & 15.82 & 8.57 & 0.18 & 6.47 & 12.19 & 1.77 & 0.31 & 0.10 & 98.70 & 60.8 & 0.770 & 0.150 & 1.20 \\
\hline
\end{tabular}

Notes: $(\mathrm{N})$ suffix $=$ analysis also given in Hergt and Nilsson (this volume). $\mathrm{Na}_{2} \mathrm{O} 8$ after Klein and Langmuir (1987). Numbers in parentheses indicate numbers of samples in mean. REP $=$ duplicate analysis. $\mathrm{ND}=$ not determined. 
APPENDIX B

Major and Trace Element XRF Analyses of Leg 135 Bulk Rocks, Sites 834 through 839

\begin{tabular}{|c|c|c|c|c|c|c|c|c|c|c|c|c|c|c|c|c|c|c|}
\hline $\begin{array}{l}\text { Core, section, } \\
\text { interval }(\mathrm{cm})\end{array}$ & Unit & $\begin{array}{l}\text { Depth } \\
\text { (mbsf) }\end{array}$ & $\mathrm{SiO}_{2}$ & $\mathrm{TiO}_{2}$ & $\mathrm{Al}_{2} \mathrm{O}_{3}$ & $\mathrm{FeO}^{*}$ & $\mathrm{Fe}_{2} \mathrm{O}_{3}$ & $\mathrm{FeO}$ & $\mathrm{MnO}$ & $\mathrm{MgO}$ & $\mathrm{CaO}$ & $\mathrm{Na}_{2} \mathrm{O}$ & $\mathrm{K}_{2} \mathrm{O}$ & $\mathrm{P}_{2} \mathrm{O}_{5}$ & Sum & $\mathrm{Zr}$ & $\mathrm{Y}$ & $\mathrm{Nb}$ \\
\hline $135-834 \mathrm{~A}-12 \mathrm{X}-\mathrm{CC}, 13-15^{*}$ & 1 & 105.96 & 49.78 & 1.40 & 17.51 & 8.47 & 1.22 & 7.37 & 0.15 & 5.06 & 12.71 & 3.08 & 0.26 & 0.15 & 99.48 & 120 & 28 & 2 \\
\hline $135-834 \mathrm{~A}-12 \mathrm{X}-\mathrm{CC}, 20-22$ & 1 & 106.03 & 47.78 & 1.28 & 21.83 & 8.00 & 1.16 & 6.96 & 0.14 & 6.24 & 11.71 & 3.38 & 0.21 & 0.19 & 100.75 & 109 & 30 & 4 \\
\hline 135-834B-6R-CC, 19-22 & 2 & 112.73 & 50.58 & 1.48 & 16.50 & 9.63 & 1.40 & 8.37 & 0.18 & 5.65 & 11.44 & 3.07 & 0.35 & 0.18 & 100.11 & 113 & 31 & 2 \\
\hline $135-834 \mathrm{~A}-14 \mathrm{X}-1,4-6^{\circ}$ & 2 & 117.04 & 50.57 & 1.49 & 16.49 & 9.74 & 1.41 & 8.47 & 0.18 & 5.77 & 11.36 & 3.10 & 0.36 & 0.18 & 100.30 & 113 & 31 & 2 \\
\hline $135-834 \mathrm{~B}-15 \mathrm{X}-1,26-40^{\circ}$. & 2 & 123.26 & 50.94 & 1.36 & 16.15 & 8.95 & 1.30 & 7.78 & 0.12 & 6.73 & 11.30 & 3.08 & 0.30 & 0.15 & 100.08 & 104 & 28 & 2 \\
\hline $135-834 \mathrm{~A}-8 \mathrm{R}-1,105-109^{\circ}$. & 2 & 127.15 & 50.70 & 1.33 & 16.24 & 9.11 & 1.32 & 7.92 & 0.13 & 7.19 & 11.04 & 3.09 & 0.18 & 0.13 & 100.13 & 102 & 27 & 1 \\
\hline $135-834 \mathrm{~A}-16 \mathrm{X}-\mathrm{CC}, 30-33^{*}$ & 4 & 134.13 & 50.81 & 1.13 & 17.55 & 8.13 & 1.18 & 7.07 & 0.13 & 6.34 & 12.59 & 2.69 & 0.11 & 0.11 & 100.47 & 89 & 24 & 2 \\
\hline $135-834 \mathrm{~A}-17 \mathrm{X}-4,93-98^{\circ}$ & 5 & 141.57 & 49.93 & 1.15 & 17.02 & 8.30 & 1.20 & 7.22 & 0.14 & 8.33 & 11.76 & 2.54 & 0.12 & 0.11 & 100.31 & 84 & 23 & 1 \\
\hline $135-834 \mathrm{~A}-18 \mathrm{X}-2,114-120^{\circ}$ & 5 & 144.09 & 50.49 & 1.13 & 16.89 & 7.85 & 1.13 & 6.83 & 0.15 & 8.05 & 12.04 & 2.67 & 0.12 & 0.11 & 100.35 & 86 & 23 & 1 \\
\hline 135-834B-10R-1, 37-43. & 5 & 145.77 & 50.27 & 1.10 & 17.04 & 8.30 & 1.20 & 7.22 & 0.15 & 8.50 & 11.66 & 2.65 & 0.12 & 0.10 & 100.80 & 84 & 23 & 1 \\
\hline $135-834 \mathrm{~A}-20 \mathrm{X}-2,82-87^{\circ}$ & 5 & 146.89 & 50.65 & 1.13 & 16.80 & 7.95 & 1.16 & 6.91 & 0.13 & 8.07 & 11.68 & 2.64 & 0.14 & 0.13 & 100.19 & 96 & 26 & 1 \\
\hline $135-834 \mathrm{~B}-12 \mathrm{R}-3,66-71^{\circ}$ & 5 & 158.60 & 50.00 & 1.05 & 17.20 & 8.01 & 1.16 & 6.97 & 0.13 & 8.99 & 11.54 & 2.57 & 0.12 & 0.10 & 100.57 & 78 & 21 & 1 \\
\hline 135-834B-13R-1, 130-131 & 5 & & 49.27 & 1.09 & 15.91 & 7.96 & 1.16 & 6.92 & 0.14 & 7.99 & 11.19 & 3.90 & 0.18 & 0.21 & 97.84 & 87 & 29 & 2 \\
\hline 135-834B-14R-1, 33-40 & 6 & 166.03 & 51.09 & 1.75 & 15.86 & 9.32 & 1.36 & 8.10 & 0.17 & 5.73 & 10.74 & 3.58 & 0.33 & 0.20 & 99.78 & 147 & 39 & 2 \\
\hline 135-834B-15R-1, 43-50. & 6 & 175.83 & 50.31 & 1.72 & 16.12 & 9.45 & 1.37 & 8.22 & 0.17 & 6.05 & 10.71 & 3.60 & 0.19 & 0.25 & 98.57 & 142 & 43 & 5 \\
\hline 135-834B-15R-2, 37-41" & 6 & 177.17 & 51.55 & 1.77 & 15.88 & 9.59 & 1.39 & 8.34 & 0.19 & 5.55 & 10.70 & 3.51 & 0.32 & 0.21 & 100.33 & 149 & 39 & 2 \\
\hline 135-834B-15R-2, 56-62 & 6 & 177.36 & 50.79 & 1.74 & 17.24 & 9.76 & 1.41 & 8.49 & 0.19 & 5.66 & 10.57 & 3.47 & 0.32 & 0.26 & 99.98 & 147 & 43 & 4 \\
\hline 135-834B-16R-1, 113-123* & 6 & 186.13 & 51.86 & 1.45 & 16.71 & 9.62 & 1.39 & 8.37 & 0.16 & 5.20 & 10.07 & 3.60 & 0.65 & 0.20 & 100.59 & 134 & 33 & 2 \\
\hline 135-834B-18R-1, 7-12 & 6 & 204.07 & 50.96 & 1.36 & 17.83 & 8.76 & 1.27 & 7.62 & 0.16 & 6.35 & 11.24 & 3.79 & 0.42 & 0.22 & 101.10 & 119 & 36 & 4 \\
\hline 135-834B-18R-1, 14-21. & 6 & 204.14 & 49.75 & 1.10 & 16.78 & 8.58 & 1.24 & 7.46 & 0.16 & 7.20 & 12.32 & 3.46 & 0.09 & 0.21 & 99.64 & 74 & 29 & 4 \\
\hline $135-834 \mathrm{~B}-18 \mathrm{R}-1,26-35^{\circ}$ & 6 & 204.26 & 50.63 & 1.41 & 16.98 & 8.60 & 1.24 & 7.48 & 0.16 & 5.91 & 11.40 & 3.31 & 0.31 & 0.21 & 99.85 & 119 & 36 & 2 \\
\hline 135-834B-20R-1, 104-111" & 7 & 214.64 & 49.91 & 1.26 & 17.10 & 8.07 & 1.17 & 7.02 & 0.15 & 6.99 & 12.32 & 2.71 & 0.16 & 0.11 & 99.66 & 96 & 26 & 1 \\
\hline 135-834B-22R-2, 29-33* & 7 & 224.99 & 49.95 & 1.28 & 17.12 & 8.11 & 1.18 & 7.05 & 0.12 & 8.27 & 11.84 & 2.60 & 0.03 & 0.11 & 100.32 & 94 & 27 & 1 \\
\hline 135-834B-23R-1, 12-18. & 7 & 228.12 & 49.50 & 1.24 & 17.41 & 7.48 & 1.09 & 6.50 & 0.13 & 6.77 & 12.44 & 3.90 & 0.10 & 0.19 & 99.15 & 96 & 27 & 2 \\
\hline 135-834B-28R-1, 44-50" & 7 & 252.74 & 49.87 & 1.20 & 17.92 & 7.59 & 1.10 & 6.60 & 0.12 & 7.46 & 12.44 & 2.52 & 0.02 & 0.11 & 100.07 & 93 & 25 & 1 \\
\hline 135-834B-29R-1, 7-12 & 7 & 257.37 & 46.68 & 1.23 & 21.61 & 7.80 & 1.13 & 6.78 & 0.14 & 5.49 & 12.41 & 3.91 & 0.12 & 0.20 & 99.59 & 102 & 29 & 3 \\
\hline 135-834B-30R-3, 101-105 & 7 & 265.85 & 49.96 & 1.25 & 17.67 & 8.09 & 1.18 & 7.03 & 0.13 & 7.84 & 12.15 & 2.59 & 0.05 & 0.12 & 100.74 & 99 & 25 & 1 \\
\hline $135-834 \mathrm{~B}-30 \mathrm{R}-3,112-120$ & 7 & 265.96 & 47.74 & 1.15 & 19.00 & 7.42 & 1.08 & 6.45 & 0.13 & 6.59 & 12.39 & 3.85 & 0.05 & 0.19 & 98.52 & 95 & 27 & 2 \\
\hline 135-834B-31R-3, 19-25" & 7 & 269.68 & 49.51 & 1.21 & 17.57 & 7.70 & 1.11 & 6.70 & 0.13 & 7.88 & 11.82 & 2.64 & 0.06 & 0.10 & 99.49 & 96 & 25 & 2 \\
\hline 135-834B-33R-1, 0-6 & 7 & 281.20 & 47.52 & 1.21 & 19.64 & 7.74 & 1.12 & 6.73 & 0.14 & 6.61 & 12.49 & 3.78 & 0.06 & 0.19 & 99.39 & 99 & 29 & 2 \\
\hline 135-834B-33R-2, 105-110. & 7 & & 48.23 & 1.16 & 16.65 & 7.83 & 1.13 & 6.81 & 0.12 & 7.48 & 11.62 & 4.06 & 0.13 & 0.21 & 97.49 & 101 & 27 & 1 \\
\hline 135-834B-33R-2, $111-115^{\circ}$ & 7 & 283.15 & 49.53 & 1.19 & 18.01 & 7.72 & 1.12 & 6.71 & 0.12 & 7.58 & 12.33 & 2.67 & 0.04 & 0.11 & 100.13 & 98 & 25 & 1 \\
\hline 135-834B-35R-1, 43-49 & 8 & 291.23 & 50.43 & 1.05 & 18.91 & 8.09 & 1.18 & 7.03 & 0.15 & 6.99 & 11.89 & 2.92 & 0.15 & 0.17 & 100.75 & 80 & 27 & 2 \\
\hline 135-834B-35R-1, 115-125 & 8 & 291.95 & 50.02 & 1.05 & 17.61 & 8.31 & 1.20 & 7.23 & 0.15 & 6.79 & 11.73 & 2.86 & 0.16 & 0.17 & 98.84 & 82 & 26 & 2 \\
\hline 135-834B-35R-2, 77-83 & 8 & 292.82 & 49.90 & 1.10 & 18.01 & 8.59 & 1.24 & 7.47 & 0.16 & 7.27 & 12.47 & 2.85 & 0.14 & 0.18 & 100.67 & 82 & 29 & 3 \\
\hline $135-834 \mathrm{~B}-35 \mathrm{R}-2,122-125^{*}$ & 8 & 293.52 & 51.76 & 1.13 & 16.37 & 8.62 & 1.24 & 7.50 & 0.16 & 7.09 & 11.97 & 2.54 & 0.22 & 0.11 & 100.92 & 81 & 25 & 2 \\
\hline 135-834B-35R-2, 129-133 & 8 & 293.34 & 51.13 & 1.11 & 17.88 & 8.42 & 1.22 & 7.32 & 0.16 & 7.08 & 11.85 & 2.96 & 0.23 & 0.18 & 101.00 & 83 & 28 & 3 \\
\hline 135-834B-36R-1, 21-25 . & 8 & 300.71 & 52.09 & 1.39 & 16.75 & 8.23 & 1.19 & 7.16 & 0.15 & 6.86 & 12.10 & 2.59 & 0.22 & 0.14 & 101.43 & 83 & 25 & 1 \\
\hline 135-834B-36R-1, 65-68". & 8 & 301.15 & 50.32 & 1.35 & 16.33 & 8.24 & 1.19 & 7.17 & 0.14 & 7.33 & 11.83 & 2.58 & 0.19 & 0.12 & 99.33 & 81 & 25 & 1 \\
\hline $135-834 \mathrm{~B}-37 \mathrm{R}-1,47-50^{\circ}$ & 9B & 310.67 & 51.21 & 1.57 & 16.66 & 9.13 & 1.32 & 7.94 & 0.17 & 6.54 & 11.45 & 3.01 & 0.31 & 0.16 & 101.21 & 118 & 35 & 2 \\
\hline 135-834B-37R-2, 42-44. & $10 \mathrm{~A}$ & 311.87 & 49.78 & 1.57 & 18.25 & 10.16 & 1.48 & 8.83 & 0.18 & 5.12 & 10.17 & 4.08 & 0.34 & 0.22 & 99.86 & 127 & 37 & 4 \\
\hline 135-834B-37R-2, 62-66 & $10 \mathrm{~A}$ & 312.07 & 54.59 & 1.79 & 16.31 & 9.20 & 1.33 & 8.00 & 0.15 & 3.80 & 8.40 & 3.94 & 0.72 & 0.23 & 100.14 & 160 & 49 & 2 \\
\hline 135-834B-39R-1, 16-21 & $10 \mathrm{~A}$ & 324.96 & 50.54 & 1.39 & 17.21 & 8.75 & 1.27 & 7.61 & 0.16 & 5.81 & 11.48 & 4.27 & 0.29 & 0.25 & 100.14 & 119 & 37 & 2 \\
\hline $135-834 \mathrm{~B}-40 \mathrm{R}-1,0-4$ & $10 \mathrm{~A}$ & 329.40 & 49.41 & 1.42 & 18.63 & 9.85 & 1.42 & 8.57 & 0.18 & 5.09 & 9.51 & 3.76 & 0.47 & 0.19 & 98.51 & 102 & 32 & 3 \\
\hline $135-834 \mathrm{~B}-42 \mathrm{R}-1,0-5$ & $10 \mathrm{~A}$ & 339.10 & 48.91 & 1.99 & 17.86 & 12.12 & 1.76 & 10.54 & 0.21 & 3.67 & 8.04 & 4.37 & 0.66 & 0.22 & 98.05 & 138 & 43 & 5 \\
\hline $135-834 \mathrm{~B}-42 \mathrm{R}-1,20-23^{\circ}$ & $10 \mathrm{~A}$ & 339.30 & 52.28 & 1.70 & 16.54 & 10.83 & 1.57 & 9.42 & 0.18 & 3.76 & 9.51 & 3.36 & 0.69 & 0.19 & 100.23 & 119 & 36 & 2 \\
\hline 135-834B-43R-1, $104-110^{*}$ & $10 \mathrm{~A}$ & 345.14 & 54.18 & 1.92 & 16.53 & 9.05 & 1.31 & 7.87 & 0.14 & 3.31 & 7.65 & 4.67 & 0.29 & 0.31 & 99.05 & 220 & 58 & 2 \\
\hline 135-834B-46R-1, 37-40. & $10 \mathrm{~B}$ & 358.87 & 49.33 & 1.13 & 16.79 & 8.55 & 1.24 & 7.43 & 0.16 & 7.41 & 12.36 & 3.23 & 0.11 & 0.20 & 99.26 & 70 & 22 & 3 \\
\hline 135-834B-47R-1, 27-37" & 12 & 363.77 & 51.51 & 2.09 & 15.31 & 12.18 & 1.77 & 10.59 & 0.20 & 3.78 & 8.37 & 3.84 & 0.53 & 0.20 & 99.33 & 146 & 41 & 2 \\
\hline 135-834B-47R-1, 130 & 12 & 374.10 & 52.98 & 1.71 & 16.55 & 9.79 & 1.42 & 8.51 & 0.18 & 4.07 & 8.12 & 4.39 & 0.63 & 0.26 & 98.69 & 160 & 50 & 5 \\
\hline 135-834B-49R-1, 131-135" & 12 & 374.51 & 52.76 & 2.09 & 15.26 & 12.15 & 1.76 & 10.57 & 0.15 & 4.31 & 7.91 & 4.00 & 0.08 & 0.20 & 100.25 & 154 & 42 & 2 \\
\hline 135-834B-51R-1, 10-15 & 12 & & 48.63 & 1.91 & 20.38 & 11.48 & 1.67 & 9.98 & 0.20 & 3.76 & 7.84 & 4.00 & 0.59 & 0.22 & 99.02 & 138 & 41 & 3 \\
\hline 135-834B-54R-1, 5-10. & 12 & & 49.23 & 2.00 & 18.81 & 12.03 & 1.74 & 10.46 & 0.21 & 3.88 & 8.12 & 3.96 & 0.58 & 0.22 & 99.03 & 139 & 45 & 3 \\
\hline 135-834B-56R-1, 7-15 & 12 & 406.97 & 52.20 & 2.11 & 15.71 & 12.41 & 1.80 & 10.79 & 0.20 & 3.40 & 8.58 & 3.87 & 0.73 & 0.21 & 100.78 & 146 & 40 & 1 \\
\hline 135-834B-58R-1, 92-99. & 13 & 426.92 & 49.37 & 1.52 & 16.80 & 10.74 & 1.56 & 9.34 & 0.19 & 5.23 & 10.23 & 3.83 & 0.46 & 0.20 & 98.57 & 105 & 35 & 3 \\
\hline 135-834B-59R-2, 16-24 & 13 & 432.59 & 50.51 & 1.41 & 16.82 & 8.66 & 1.26 & 7.53 & 0.16 & 6.97 & 12.60 & 2.62 & 0.24 & 0.15 & 101.08 & 83 & 26 & 1 \\
\hline 135-834B-59R-2, 52-55 & 13 & 432.95 & 45.54 & 1.04 & 25.53 & 7.71 & 1.12 & 6.70 & 0.14 & 6.77 & 11.05 & 2.55 & 0.16 & 0.17 & 100.67 & 80 & 26 & 4 \\
\hline 135-835B-3R-1, 140-143* & 1 & 155.70 & soco & 1.14 & 16.63 & 8.93 & 1.29 & 7.77 & 0.17 & 7.52 & 12.76 & 1.95 & 0.24 & 0.13 & 100.71 & 46 & 23 & 0 \\
\hline $135-835 B-3 R-2,20-25$ & 1 & 155.94 & 50.67 & 0.85 & 16.62 & 8.64 & 1.26 & 7.51 & 0.15 & 6.89 & 12.59 & 2.03 & 0.30 & 0.19 & 98.93 & 51 & 24 & 0.5 \\
\hline
\end{tabular}


APPENDIX B (continued).

\begin{tabular}{|c|c|c|c|c|c|c|c|c|c|c|c|c|c|c|c|}
\hline $\begin{array}{l}\text { Core, section, } \\
\text { interval }(\mathrm{cm})\end{array}$ & $\mathrm{Sr}$ & $\mathrm{Rb}$ & $\mathrm{Ba}$ & $\mathrm{Ni}$ & $\mathrm{Cr}$ & V & $\mathrm{Ce}$ & Mg\# & $\mathrm{CaO} / \mathrm{Al}_{2} \mathrm{O}_{3}$ & $\mathrm{Na}_{2} \mathrm{O} / \mathrm{CaO}$ & $\mathrm{Ti} / \mathrm{Zr}$ & $\mathrm{Y} / \mathrm{Zr}$ & $\mathrm{FeO}^{*} / \mathrm{MgO}$ & $\mathrm{CaO} / \mathrm{TiO}_{2}$ & $\mathrm{Al}_{2} \mathrm{O}_{3} / \mathrm{TiO}_{2}$ \\
\hline $135-834 \mathrm{~A}-12 \mathrm{X}-\mathrm{CC}, 13-15^{*}$ & 245 & 5 & 41 & 53 & 267 & ND & 22 & 55.00 & 0.73 & 0.24 & 69.90 & 0.23 & 1.46 & 9.08 & 12.51 \\
\hline $135-834 \mathrm{~A}-12 \mathrm{X}-\mathrm{CC}, 20-22$ & 229 & 4 & 26 & 58 & ND & 231 & ND & 61.50 & 0.54 & 0.29 & 70.40 & 0.28 & 1.11 & 9.15 & 17.05 \\
\hline $135-834 \mathrm{~B}-6 \mathrm{R}-\mathrm{CC}, 19-22^{\circ}$ & 211 & 6 & 46 & 27 & 11 & ND & 16 & 54.60 & 0.69 & 0.27 & 78.50 & 0.27 & 1.48 & 7.73 & 11.15 \\
\hline $135-834 \mathrm{~A}-14 \mathrm{X}-1,4-6^{\circ}$ & 210 & 5 & 64 & 27 & 6 & ND & 14 & 54.80 & 0.69 & 0.27 & 79.10 & 0.27 & 1.47 & 7.62 & 11.07 \\
\hline $135-834 \mathrm{~B}-15 \mathrm{X}-1,26-40^{*}$ & 204 & 3 & 62 & 54 & 32 & ND & 11 & 60.60 & 0.70 & 0.27 & 78.40 & 0.27 & 1.16 & 8.31 & 11.88 \\
\hline $135-834 \mathrm{~A}-8 \mathrm{R}-1,105-109^{\circ}$ & 187 & 1 & 49 & 40 & 41 & ND & 13 & 61.80 & 0.68 & 0.28 & 78.20 & 0.27 & 1.10 & 8.30 & 12.21 \\
\hline $135-834 \mathrm{~A}-16 \mathrm{X}-\mathrm{CC}, 30-33^{*}$ & 186 & 0.1 & 35 & 105 & 234 & ND & 15 & 61.50 & 0.72 & 0.21 & 76.10 & 0.27 & 1.12 & 11.14 & 15.53 \\
\hline $135-834 \mathrm{~A}-17 \mathrm{X}-4,93-98$ & 170 & 1 & 49 & 81 & 202 & ND & 10 & 67.30 & 0.69 & 0.22 & 82.10 & 0.27 & 0.87 & 10.23 & 14.80 \\
\hline $135-834 \mathrm{~A}-18 \mathrm{X}-2,114-120^{\circ}$ & 176 & i & 44 & 78 & 169 & ND & 6 & 67.80 & 0.71 & 0.22 & 78.80 & 0.27 & 0.85 & 10.65 & 14.95 \\
\hline 135-834B-10R-1, 37-43 & 183 & i & 50 & 90 & 148 & ND & 6 & 67.70 & 0.68 & 0.23 & 78.50 & 0.27 & 0.85 & 10.60 & 15.49 \\
\hline $135-834 \mathrm{~A}-20 \mathrm{X}-2,82-87^{\circ}$ & 180 & 1 & 41 & 80 & 146 & ND & 12 & 67.50 & 0.70 & 0.23 & 70.60 & 0.27 & 0.86 & 10.34 & 14.87 \\
\hline $135-834 \mathrm{~B}-12 \mathrm{R}-3,66-71^{\circ}$ & 170 & 1 & 49 & 91 & 191 & ND & 7 & 69.70 & 0.67 & 0.22 & 80.70 & 0.27 & 0.77 & 10.99 & 16.38 \\
\hline $135-834$ B- 13 R- $1,130-131$ & 176 & $i$ & ND & 96 & ND & ND & ND & 67.30 & 0.70 & 0.35 & 75.10 & 0.33 & 0.87 & 10.27 & 14.60 \\
\hline $135-834 \mathrm{~B}-14 \mathrm{R}-1,33-40^{\circ}$ & 180 & 5 & 43 & 36 & 87 & ND & 16 & 55.80 & 0.68 & 0.33 & 71.40 & 0.27 & 1.41 & 6.14 & 9.06 \\
\hline 135-834B-15R-1, 43-50, & 176 & 1 & 35 & 41 & ND & 288 & ND & 56.80 & 0.66 & 0.34 & 72.60 & 0.30 & 1.36 & 6.23 & 9.37 \\
\hline $135-834 \mathrm{~B}-15 \mathrm{R}-2,37-41^{\circ}$ & 180 & 5 & 53 & 37 & 87 & ND & 11 & 54.30 & 0.67 & 0.33 & 71.20 & 0.26 & 1.50 & 6.05 & 8.97 \\
\hline $135-834 \mathrm{~B}-15 \mathrm{R}-2,56-62$ & 179 & 3 & 36 & 38 & ND & 281 & ND & 54.30 & 0.61 & 0.33 & 71.00 & 0.29 & 1.50 & 6.07 & 9.91 \\
\hline $135-834 \mathrm{~B}-16 \mathrm{R}-1,113-123^{\circ}$ & 197 & 12 & 45 & 42 & 50 & ND & 14 & 52.60 & 0.60 & 0.36 & 64.90 & 0.25 & 1.61 & 6.94 & 11.52 \\
\hline $135-834 \mathrm{~B}-18 \mathrm{R}-1,7-12$ & 161 & 5 & 30 & 71 & ND & 247 & ND & 59.80 & 0.63 & 0.34 & 68.50 & 0.30 & 1.20 & 8.26 & 13.11 \\
\hline 135-834B-18R-1, 14-21. & 161 & 2 & 32 & 55 & ND & 241 & ND & 63.20 & 0.73 & 0.28 & 89.10 & 0.39 & 1.04 & 11.20 & 15.25 \\
\hline $135-834 \mathrm{~B}-18 \mathrm{R}-1,26-35^{\circ}$ & 170 & 5 & 38 & 70 & 208 & ND & 13 & 58.50 & 0.67 & 0.29 & 71.00 & 0.30 & 1.27 & 8.09 & 12.04 \\
\hline 135-834B-20R-1, $104-111^{\circ}$ & 164 & 3 & 24 & 108 & 281 & ND & 7 & 64.00 & 0.72 & 0.22 & 78.70 & 0.27 & 1.00 & 9.78 & 13.57 \\
\hline $135-834 \mathrm{~B}-22 \mathrm{R}-2,29-33^{\circ}$ & 150 & 0 & 9 & 96 & 254 & ND & 7 & 67.60 & 0.69 & 0.22 & 81.60 & 0.29 & 0.85 & 9.25 & 13.38 \\
\hline $135-834 \mathrm{~B}-23 \mathrm{R}-1,12-18$ & 162 & 2 & 28 & 103 & ND & 214 & ND & 65.00 & 0.71 & 0.31 & 77.40 & 0.28 & 0.96 & 10.03 & 14.04 \\
\hline $135-834 \mathrm{~B}-28 \mathrm{R}-1,44-50^{\circ}$ & 162 & 1 & 16 & 100 & 304 & ND & 11 & 66.80 & 0.69 & 0.20 & 77.40 & 0.27 & 0.88 & 10.37 & 14.93 \\
\hline $135-834 \mathrm{~B}-29 \mathrm{R}-1,7-12$ & 176 & 3 & 22 & 102 & ND & 227 & ND & 59.10 & 0.57 & 0.32 & 72.30 & 0.28 & 1.24 & 10.09 & 17.57 \\
\hline $135-834 \mathrm{~B}-30 \mathrm{R}-3,101-105^{\circ}$ & 168 & 0 & 15 & 96 & 285 & ND & 8 & 66.50 & 0.69 & 0.21 & 75.70 & 0.25 & 0.90 & 9.72 & 14.14 \\
\hline $135-834 \mathrm{~B}-30 \mathrm{R}-3,112-120$ & 184 & 1 & 25 & 96 & ND & 199 & ND & 64.50 & 0.65 & 0.31 & 72.60 & 0.28 & 0.98 & 10.77 & 16.52 \\
\hline $135-834 \mathrm{~B}-31 \mathrm{R}-3,19-25^{\circ}$ & 167 & $i$ & 22 & 95 & 313 & ND & 11 & 67.70 & 0.67 & 0.22 & 75.60 & 0.26 & 0.85 & 9.77 & 14.52 \\
\hline $135-834 \mathrm{~B}-33 \mathrm{R}-1,0-6$ & 169 & 2 & 21 & 84 & ND & 199 & ND & 63.60 & 0.64 & 0.30 & 73.30 & 0.29 & 1.02 & 10.32 & 16.23 \\
\hline $135-834 \mathrm{~B}-33 \mathrm{R}-2,105-110$ & 169 & 1 & 22 & 93 & ND & 178 & ND & 66.20 & 0.70 & 0.35 & 68.90 & 0.27 & 0.91 & 10.02 & 14.35 \\
\hline $135-834 \mathrm{~B}-33 \mathrm{R}-2,111-115^{\circ}$ & 164 & 0 & 14 & 89 & 293 & ND & 16 & 66.80 & 0.68 & 0.22 & 72.80 & 0.26 & 0.89 & 10.36 & 15.13 \\
\hline 135-834B-35R-1, 43-49 & 153 & 1 & 30 & 59 & ND & 225 & ND & 63.90 & 0.63 & 0.25 & 78.70 & 0.34 & 1.01 & 11.32 & 18.01 \\
\hline $135-834 \mathrm{~B}-35 \mathrm{R}-1,115-125$ & 154 & 2 & 37 & 56 & ND & 224 & ND & 62.60 & 0.67 & 0.24 & 76.80 & 0.32 & 1.06 & 11.17 & 16.77 \\
\hline $135-834 \mathrm{~B}-35 \mathrm{R}-2,77-83$ & 170 & 3 & 27 & 72 & ND & 235 & ND & 63.40 & 0.69 & 0.23 & 80.40 & 0.35 & 1.03 & 11.34 & 16.37 \\
\hline $135-834 \mathrm{~B}-35 \mathrm{R}-2,122-125^{\circ}$ & 159 & 3 & 35 & 55 & 158 & ND & 9 & 62.80 & 0.73 & 0.21 & 83.60 & 0.31 & 1.06 & 10.59 & 14.49 \\
\hline $135-834 \mathrm{~B}-35 \mathrm{R}-2,129-133$ & 159 & 4 & 36 & 59 & ND & 227 & ND & 63.30 & 0.66 & 0.25 & 80.20 & 0.34 & 1.03 & 10.68 & 16.11 \\
\hline $135-834 \mathrm{~B}-36 \mathrm{R}-1,21-25$ & 160 & 4 & 42 & 53 & 137 & ND & 8 & 63.10 & 0.72 & 0.21 & 100.40 & 0.30 & 1.04 & 8.71 & 12.05 \\
\hline 135-834B-36R-1, 65-68" & 165 & 3 & 36 & 52 & 139 & ND & 13 & 64.60 & 0.72 & 0.22 & 99.90 & 0.31 & 0.98 & 8.76 & 12.10 \\
\hline $135-834 \mathrm{~B}-37 \mathrm{R}-1,47-50^{\circ}$ & 142 & 5 & 40 & 115 & 196 & ND & 16 & 59.50 & 0.69 & 0.26 & 79.80 & 0.30 & 1.21 & 7.29 & 10.61 \\
\hline $135-834 \mathrm{~B}-37 \mathrm{R}-2,42-44$. & 182 & 3 & 39 & 27 & ND & 283 & ND & 50.80 & 0.56 & 0.40 & 74.10 & 0.29 & 1.73 & 6.48 & 11.62 \\
\hline $135-834 B-37 R-2,62-66^{\circ}$ & 152 & 12 & 60 & 24 & 17 & ND & 16 & 45.80 & 0.52 & 0.47 & 67.10 & 0.31 & 2.11 & 4.69 & 9.11 \\
\hline $135-834 \mathrm{~B}-39 \mathrm{R}-1,16-21$ & 170 & 6 & 34 & 70 & ND & 255 & ND & 57.60 & 0.67 & 0.37 & 70.00 & 0.31 & 1.31 & 8.26 & 12.38 \\
\hline $135-834 \mathrm{~B}-40 \mathrm{R}-1,0-4$ & 179 & 4 & 38 & 32 & ND & 301 & ND & 51.40 & 0.51 & 0.40 & 83.50 & 0.31 & 1.68 & 6.70 & 13.12 \\
\hline $135-834 \mathrm{~B}-42 \mathrm{R}-1,0-5$ & 186 & 7 & 42 & 12 & ND & 367 & ND & 38.30 & 0.45 & 0.54 & 86.40 & 0.31 & 2.87 & 4.04 & 8.97 \\
\hline $135-834 \mathrm{~B}-42 \mathrm{R}-1,20-23^{\circ}$ & 199 & 12 & 57 & 24 & 2 & ND & 17 & 41.60 & 0.57 & 0.35 & 85.60 & 0.30 & 2.50 & 5.59 & 9.73 \\
\hline $135-834 \mathrm{~B}-43 \mathrm{R}-1,104-110^{\circ}$ & 182 & 3 & 72 & 8 & 0 & ND & 22 & 42.80 & 0.46 & 0.61 & 52.30 & 0.26 & 2.38 & 3.98 & 8.61 \\
\hline $135-834 \mathrm{~B}-46 \mathrm{R}-1,37-40$ & 155 & 2 & 30 & 74 & ND & 212 & ND & 64.00 & 0.74 & 0.26 & 96.80 & 0.31 & 1.00 & 10.94 & 14.86 \\
\hline $135-834 \mathrm{~B}-47 \mathrm{R}-1,27-37^{\circ}$ & 196 & 10 & 70 & 10 & 0 & ND & 12 & 38.90 & 0.55 & 0.46 & 85.80 & 0.28 & 2.80 & 4.00 & 7.33 \\
\hline $135-834 \mathrm{~B}-47 \mathrm{R}-1,130$ & 148 & 13 & 48 & 21 & ND & 278 & ND & 46.00 & 0.49 & 0.54 & 64.10 & 0.31 & 2.09 & 4.75 & 9.68 \\
\hline $135-834 \mathrm{~B}-49 \mathrm{R}-1,131-135^{\circ}$ & 189 & 0 & 63 & 5 & 0 & ND & 12 & 42.10 & 0.52 & 0.51 & 81.40 & 0.27 & 2.45 & 3.78 & 7.30 \\
\hline 135-834B-5IR-1, 10-15 & 181 & 10 & 45 & 10 & ND & 356 & ND & 40.20 & 0.38 & 0.51 & 83.00 & 0.30 & 2.65 & 4.10 & 10.67 \\
\hline $135-834 \mathrm{~B}-54 \mathrm{R}-1,5-10$ & 187 & 6 & 41 & 12 & ND & 349 & ND & 39.80 & 0.43 & 0.49 & 86.30 & 0.32 & 2.70 & 4.06 & 9.41 \\
\hline $135-834 \mathrm{~B}-56 \mathrm{R}-1,7-15^{\circ}$ & 195 & 13 & 60 & 12 & 0 & ND & 15 & 36.00 & 0.55 & 0.45 & 86.60 & 0.27 & 3.17 & 4.07 & 7.45 \\
\hline 135-834B-58R-1, 92-99. & 192 & 11 & 38 & 32 & ND & 324 & ND & 50.00 & 0.61 & 0.37 & 86.80 & 0.33 & 1.79 & 6.73 & 11.05 \\
\hline $135-834 \mathrm{~B}-59 \mathrm{R}-2,16-24^{\circ}$ & 169 & 6 & 38 & 71 & 170 & ND & 4 & 62.30 & 0.75 & 0.21 & 101.80 & 0.31 & 1.08 & 8.94 & 11.93 \\
\hline $135-834 \mathrm{~B}-59 \mathrm{R}-2,52-55$ & 148 & 2 & 38 & 65 & ND & 221 & ND & 64.30 & 0.43 & 0.23 & 77.90 & 0.33 & 0.99 & 10.63 & 24.55 \\
\hline $135-835 B-3 R-1,140-143^{\circ}$ & 135 & 4 & 40 & 67 & 161 & ND & 6 & 63.30 & 0.77 & 0.15 & 148.60 & 0.50 & 1.03 & 11.19 & 14.59 \\
\hline $135-835 B-3 R-2,20-25$ & 139 & 3 & 28 & 79 & ND & 246 & ND & 62.00 & 0.76 & 0.16 & 99.90 & 0.47 & 1.09 & 14.81 & 19.55 \\
\hline
\end{tabular}




\begin{tabular}{|c|c|c|c|c|c|c|c|c|c|c|c|c|c|c|c|c|c|c|}
\hline $\begin{array}{l}\text { Core, section, } \\
\text { interval }(\mathrm{cm})\end{array}$ & Unit & $\begin{array}{l}\text { Depth } \\
\text { (mbsf) }\end{array}$ & $\mathrm{SiO}_{2}$ & $\mathrm{TiO}_{2}$ & $\mathrm{Al}_{2} \mathrm{O}_{3}$ & $\mathrm{FeO}^{*}$ & $\mathrm{Fe}_{2} \mathrm{O}_{3}$ & $\mathrm{FeO}$ & $\mathrm{MnO}$ & $\mathrm{MgO}$ & $\mathrm{CaO}$ & $\mathrm{Na}_{2} \mathrm{O}$ & $\mathrm{K}_{2} \mathrm{O}$ & $\mathrm{P}_{2} \mathrm{O}_{5}$ & Sum & $\mathrm{Zr}$ & $\mathrm{Y}$ & $\mathrm{Nb}$ \\
\hline $\begin{array}{l}\text { 135-835B-4R-1, 16-20* } \\
135-835 \mathrm{~B}-6 \mathrm{R}-1,32-37^{*} \\
135-835 \mathrm{~B}-6 \mathrm{R}-1,114-117^{*} \\
135-835 \mathrm{~B}-7 \mathrm{R}-1,40-44^{\circ} \\
\text { 135-835B-7R-2, 75-84 } \\
135-835 \mathrm{~B}-7 \mathrm{R}-2,84-89^{\circ}\end{array}$ & $\begin{array}{l}1 \\
1 \\
1 \\
1 \\
1 \\
1\end{array}$ & $\begin{array}{l}164.16 \\
174.02 \\
174.84 \\
179.10 \\
179.95 \\
180.85\end{array}$ & $\begin{array}{l}50.14 \\
50.35 \\
49.80 \\
50.53 \\
51.22 \\
50.39\end{array}$ & $\begin{array}{l}1.15 \\
1.09 \\
1.23 \\
1.11 \\
0.80 \\
1.14\end{array}$ & $\begin{array}{l}16.43 \\
16.47 \\
16.17 \\
16.59 \\
15.72 \\
16.22\end{array}$ & $\begin{array}{l}9.22 \\
8.46 \\
9.66 \\
8.71 \\
8.24 \\
8.49\end{array}$ & $\begin{array}{l}1.33 \\
1.22 \\
1.40 \\
1.27 \\
1.19 \\
1.23\end{array}$ & $\begin{array}{l}8.02 \\
7.36 \\
8.40 \\
7.57 \\
7.17 \\
7.38\end{array}$ & $\begin{array}{l}0.17 \\
0.16 \\
0.19 \\
0.17 \\
0.12 \\
0.12\end{array}$ & $\begin{array}{l}7.65 \\
7.67 \\
6.70 \\
7.67 \\
7.71 \\
7.98\end{array}$ & $\begin{array}{l}12.58 \\
12.90 \\
12.33 \\
12.83 \\
12.27 \\
12.16\end{array}$ & $\begin{array}{l}1.79 \\
1.82 \\
2.19 \\
1.81 \\
2.17 \\
2.11\end{array}$ & $\begin{array}{l}0.24 \\
0.28 \\
0.21 \\
0.23 \\
0.17 \\
0.12\end{array}$ & $\begin{array}{l}0.12 \\
0.11 \\
0.12 \\
0.10 \\
0.19 \\
0.11\end{array}$ & $\begin{array}{r}100.50 \\
100.23 \\
99.66 \\
100.70 \\
98.61 \\
99.77\end{array}$ & $\begin{array}{l}45 \\
44 \\
49 \\
45 \\
51 \\
45\end{array}$ & $\begin{array}{l}23 \\
22 \\
25 \\
22 \\
25 \\
22\end{array}$ & $\begin{array}{l}1 \\
1 \\
1 \\
1 \\
1 \\
2 \\
1\end{array}$ \\
\hline $\begin{array}{l}135-836 \mathrm{~A}-3 \mathrm{H}-2,83-85 \\
135-836 \mathrm{~A}-3 \mathrm{H}-3,33-43 \\
135-836 \mathrm{~A}-3 \mathrm{H}-4,75-150^{\circ} \\
135-836 \mathrm{~A}-3 \mathrm{H}-4,88-100 \\
135-836 \mathrm{~A}-3 \mathrm{H}-7,54-55 \\
135-836 \mathrm{~A}-4 \mathrm{H}-\mathrm{CC}, 0-13 \\
135-836 \mathrm{~A}-3 \mathrm{H}-\mathrm{CC}, 0-9\end{array}$ & $\begin{array}{l}1 \\
1 \\
2 \\
2 \\
3 \\
3 \\
3\end{array}$ & $\begin{array}{l}13.03 \\
14.50 \\
15.83 \\
18.00 \\
20.12 \\
20.20 \\
20.36\end{array}$ & $\begin{array}{l}54.06 \\
54.89 \\
56.99 \\
55.77 \\
47.13 \\
49.17 \\
48.34\end{array}$ & $\begin{array}{l}1.42 \\
1.27 \\
1.16 \\
1.12 \\
0.69 \\
0.76 \\
0.73\end{array}$ & $\begin{array}{l}16.57 \\
14.24 \\
14.48 \\
14.07 \\
19.18 \\
18.54 \\
17.81\end{array}$ & $\begin{array}{r}12.10 \\
11.70 \\
11.18 \\
11.04 \\
8.08 \\
8.64 \\
8.53\end{array}$ & $\begin{array}{l}1.76 \\
1.70 \\
1.62 \\
1.60 \\
1.17 \\
1.26 \\
1.23\end{array}$ & $\begin{array}{r}10.52 \\
10.17 \\
9.72 \\
9.60 \\
7.03 \\
7.51 \\
7.42\end{array}$ & $\begin{array}{l}0.20 \\
0.18 \\
0.23 \\
0.23 \\
0.16 \\
0.16 \\
0.16\end{array}$ & $\begin{array}{l}4.03 \\
3.87 \\
3.53 \\
3.69 \\
8.88 \\
8.90 \\
8.93\end{array}$ & $\begin{array}{r}8.61 \\
8.60 \\
8.06 \\
8.24 \\
13.03 \\
13.69 \\
13.52\end{array}$ & $\begin{array}{l}2.90 \\
3.02 \\
2.91 \\
3.12 \\
1.90 \\
1.99 \\
2.08\end{array}$ & $\begin{array}{l}0.20 \\
0.28 \\
0.26 \\
0.31 \\
0.00 \\
0.03 \\
0.02\end{array}$ & $\begin{array}{l}0.17 \\
0.20 \\
0.14 \\
0.20 \\
0.14 \\
0.15 \\
0.14\end{array}$ & $\begin{array}{r}100.25 \\
98.26 \\
100.17 \\
97.80 \\
99.20 \\
102.57 \\
100.26\end{array}$ & $\begin{array}{l}74 \\
79 \\
78 \\
80 \\
47 \\
47 \\
48\end{array}$ & $\begin{array}{l}36 \\
32 \\
34 \\
35 \\
19 \\
23 \\
20\end{array}$ & $\begin{array}{l}3 \\
2 \\
2 \\
3 \\
2 \\
2 \\
1\end{array}$ \\
\hline 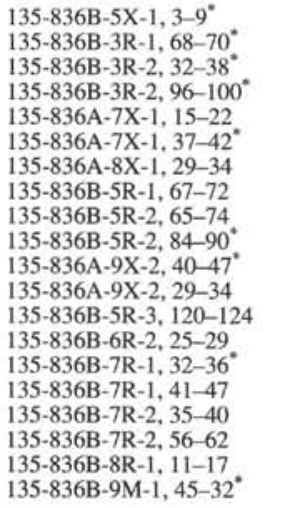 & $\begin{array}{l}3 \\
4 \mathrm{~A} \\
4 \mathrm{~A} \\
4 \mathrm{~A} \\
4 \\
4 \\
4 \\
4 \mathrm{~B} \\
4 \mathrm{~B} \\
4 \mathrm{~B} \\
4 \\
4 \\
4 \mathrm{~B} \\
4 \mathrm{~B} \\
5 \\
5 \\
5 \\
5 \\
5 \\
5 ?\end{array}$ & $\begin{array}{l}21.23 \\
23.68 \\
24.72 \\
25.36 \\
25.85 \\
26.07 \\
31.49 \\
34.67 \\
35.50 \\
36.32 \\
36.78 \\
36.95 \\
37.93 \\
40.46 \\
44.02 \\
44.11 \\
45.55 \\
45.76 \\
53.41 \\
54.00\end{array}$ & $\begin{array}{l}49.34 \\
48.38 \\
48.94 \\
48.96 \\
48.72 \\
48.52 \\
50.22 \\
49.08 \\
49.61 \\
48.50 \\
49.17 \\
49.07 \\
48.97 \\
47.92 \\
52.06 \\
50.82 \\
50.87 \\
48.08 \\
52.13 \\
52.15\end{array}$ & $\begin{array}{l}0.75 \\
0.75 \\
0.79 \\
0.77 \\
0.73 \\
0.76 \\
1.05 \\
0.65 \\
0.73 \\
0.75 \\
0.72 \\
0.72 \\
0.71 \\
0.71 \\
1.14 \\
1.10 \\
1.06 \\
0.72 \\
1.08 \\
1.18\end{array}$ & $\begin{array}{l}16.62 \\
16.59 \\
16.11 \\
16.37 \\
16.17 \\
16.49 \\
18.72 \\
17.01 \\
15.21 \\
16.28 \\
16.49 \\
16.39 \\
16.46 \\
16.30 \\
15.44 \\
17.40 \\
16.81 \\
16.21 \\
16.42 \\
15.31\end{array}$ & $\begin{array}{r}7.91 \\
8.36 \\
8.27 \\
8.14 \\
8.40 \\
8.53 \\
10.84 \\
8.15 \\
8.42 \\
8.43 \\
8.16 \\
8.13 \\
8.37 \\
8.13 \\
10.94 \\
11.07 \\
10.96 \\
8.13 \\
11.04 \\
11.45\end{array}$ & $\begin{array}{l}1.14 \\
1.21 \\
1.20 \\
1.18 \\
1.22 \\
1.23 \\
1.57 \\
1.18 \\
1.22 \\
1.22 \\
1.18 \\
1.18 \\
1.21 \\
1.18 \\
1.59 \\
1.60 \\
1.59 \\
1.18 \\
1.60 \\
1.66\end{array}$ & $\begin{array}{l}6.88 \\
7.27 \\
7.19 \\
7.08 \\
7.30 \\
7.42 \\
9.43 \\
7.09 \\
7.32 \\
7.33 \\
7.10 \\
7.07 \\
7.28 \\
7.07 \\
9.51 \\
9.63 \\
9.53 \\
7.07 \\
9.60 \\
9.96\end{array}$ & $\begin{array}{l}0.17 \\
0.15 \\
0.12 \\
0.13 \\
0.14 \\
0.14 \\
0.19 \\
0.14 \\
0.13 \\
0.15 \\
0.14 \\
0.13 \\
0.12 \\
0.13 \\
0.20 \\
0.19 \\
0.19 \\
0.14 \\
0.19 \\
0.20\end{array}$ & $\begin{array}{l}8.66 \\
7.98 \\
7.68 \\
8.66 \\
8.85 \\
9.43 \\
5.66 \\
9.52 \\
9.41 \\
9.52 \\
9.80 \\
9.38 \\
9.21 \\
9.25 \\
5.33 \\
5.36 \\
5.65 \\
9.07 \\
5.89 \\
5.37\end{array}$ & $\begin{array}{l}14.10 \\
14.46 \\
14.85 \\
14.32 \\
13.65 \\
13.93 \\
10.67 \\
13.79 \\
13.62 \\
13.06 \\
13.43 \\
13.43 \\
13.10 \\
12.97 \\
10.72 \\
10.67 \\
10.89 \\
13.78 \\
11.05 \\
10.53\end{array}$ & $\begin{array}{l}1.72 \\
1.98 \\
1.96 \\
1.78 \\
2.20 \\
1.89 \\
2.49 \\
2.35 \\
2.17 \\
1.81 \\
1.88 \\
2.19 \\
2.18 \\
2.14 \\
2.22 \\
2.20 \\
2.39 \\
2.33 \\
2.34 \\
2.27\end{array}$ & $\begin{array}{l}0.12 \\
0.11 \\
0.15 \\
0.04 \\
\text { ND } \\
0.04 \\
0.23 \\
0.01 \\
0.12 \\
0.04 \\
0.05 \\
0.01 \\
0.02 \\
0.01 \\
0.30 \\
0.43 \\
0.29 \\
0.01 \\
0.22 \\
0.33\end{array}$ & $\begin{array}{l}0.06 \\
0.06 \\
0.06 \\
0.05 \\
0.15 \\
0.05 \\
0.16 \\
0.13 \\
0.18 \\
0.05 \\
0.05 \\
0.13 \\
0.14 \\
0.14 \\
0.11 \\
0.15 \\
0.16 \\
0.14 \\
0.16 \\
0.11\end{array}$ & $\begin{array}{r}100.40 \\
99.72 \\
99.84 \\
100.12 \\
99.02 \\
100.70 \\
100.23 \\
100.82 \\
99.60 \\
99.50 \\
100.78 \\
99.57 \\
99.27 \\
97.71 \\
99.66 \\
99.39 \\
99.27 \\
98.59 \\
100.51 \\
100.15\end{array}$ & $\begin{array}{l}43 \\
56 \\
53 \\
45 \\
47 \\
46 \\
59 \\
43 \\
49 \\
42 \\
41 \\
48 \\
48 \\
49 \\
57 \\
62 \\
60 \\
44 \\
59 \\
60\end{array}$ & $\begin{array}{l}18 \\
18 \\
18 \\
17 \\
18 \\
17 \\
28 \\
18 \\
18 \\
17 \\
18 \\
18 \\
20 \\
20 \\
26 \\
28 \\
26 \\
20 \\
26 \\
27\end{array}$ & $\begin{array}{l}1 \\
1 \\
1 \\
1 \\
1 \\
1 \\
2 \\
2 \\
2 \\
0 \\
1 \\
2 \\
2 \\
1 \\
1 \\
4 \\
4 \\
2 \\
2 \\
1\end{array}$ \\
\hline $\begin{array}{l}\text { 135-837B-2R-1, 24-30 } \\
\text { 135-837B-2R-1, 30-36 } \\
\text { 135-837B-3R-1, 34-39 } \\
\text { 135-837B-3R-1, 137-140 } \\
\text { 135-837B-4R-1, 36-41 } \\
135-837 \mathrm{~B}-5 \mathrm{R}-1,62-69^{\circ}\end{array}$ & $\begin{array}{l}1 \\
1 \\
1 \\
1 \\
1 \\
1\end{array}$ & $\begin{array}{l}70.74 \\
70.80 \\
80.54 \\
81.57 \\
85.56 \\
90.52\end{array}$ & $\begin{array}{l}54.40 \\
55.28 \\
55.95 \\
54.94 \\
55.23 \\
55.93\end{array}$ & $\begin{array}{l}1.34 \\
1.36 \\
1.35 \\
1.32 \\
1.33 \\
1.36\end{array}$ & $\begin{array}{l}14.56 \\
15.44 \\
15.39 \\
15.97 \\
15.34 \\
14.86\end{array}$ & $\begin{array}{l}11.53 \\
11.71 \\
11.95 \\
11.62 \\
11.67 \\
11.27\end{array}$ & $\begin{array}{l}1.67 \\
1.70 \\
1.73 \\
1.69 \\
1.69 \\
1.63\end{array}$ & $\begin{array}{r}10.03 \\
10.18 \\
10.39 \\
10.10 \\
10.15 \\
9.80\end{array}$ & $\begin{array}{l}0.21 \\
0.20 \\
0.20 \\
0.20 \\
0.20 \\
0.21\end{array}$ & $\begin{array}{l}3.38 \\
3.49 \\
3.57 \\
3.50 \\
3.56 \\
3.45\end{array}$ & $\begin{array}{l}7.92 \\
8.09 \\
8.24 \\
8.05 \\
8.12 \\
8.08\end{array}$ & $\begin{array}{l}2.62 \\
2.92 \\
2.84 \\
2.91 \\
3.06 \\
2.62\end{array}$ & $\begin{array}{l}0.66 \\
0.69 \\
0.71 \\
0.63 \\
0.75 \\
0.72\end{array}$ & $\begin{array}{l}0.16 \\
0.23 \\
0.22 \\
0.23 \\
0.23 \\
0.17\end{array}$ & $\begin{array}{r}98.06 \\
99.39 \\
100.43 \\
99.37 \\
99.50 \\
99.92\end{array}$ & $\begin{array}{l}75 \\
82 \\
83 \\
80 \\
79 \\
76\end{array}$ & $\begin{array}{l}35 \\
36 \\
37 \\
35 \\
35 \\
36\end{array}$ & $\begin{array}{l}3 \\
3 \\
3 \\
4 \\
5 \\
2\end{array}$ \\
\hline 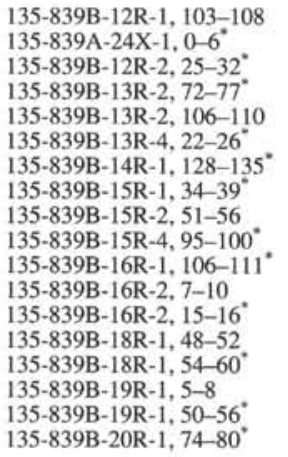 & $\begin{array}{l}1 \\
1 \\
1 \\
1 \\
1 \\
1 \\
1 \\
1 \\
1 \\
1 \\
1 \\
1 \\
1 \\
1 \\
2 \\
2 \\
2 \\
2 \\
3 \\
3\end{array}$ & $\begin{array}{l}214.53 \\
215.20 \\
215.23 \\
220.42 \\
220.76 \\
222.69 \\
228.48 \\
237.64 \\
239.02 \\
242.41 \\
248.06 \\
248.53 \\
248.61 \\
266.88 \\
266.94 \\
276.05 \\
276.50 \\
286.44\end{array}$ & $\begin{array}{l}53.00 \\
53.03 \\
52.36 \\
52.70 \\
52.51 \\
52.31 \\
53.01 \\
53.28 \\
51.67 \\
52.30 \\
52.28 \\
52.59 \\
52.50 \\
52.70 \\
54.92 \\
52.47 \\
50.63 \\
50.20\end{array}$ & $\begin{array}{l}0.60 \\
0.65 \\
0.60 \\
0.62 \\
0.62 \\
0.60 \\
0.60 \\
0.65 \\
0.62 \\
0.60 \\
0.66 \\
0.59 \\
0.63 \\
0.82 \\
0.90 \\
0.84 \\
0.58 \\
0.57\end{array}$ & $\begin{array}{l}16.69 \\
15.06 \\
15.15 \\
15.05 \\
15.13 \\
14.98 \\
15.54 \\
14.98 \\
14.64 \\
14.45 \\
14.94 \\
16.32 \\
14.84 \\
18.38 \\
16.08 \\
17.56 \\
12.75 \\
12.48\end{array}$ & $\begin{array}{r}8.80 \\
9.04 \\
8.95 \\
9.05 \\
8.76 \\
8.94 \\
8.48 \\
8.46 \\
8.83 \\
9.30 \\
9.13 \\
8.96 \\
9.14 \\
9.51 \\
10.10 \\
9.51 \\
8.94 \\
9.16\end{array}$ & $\begin{array}{l}1.28 \\
1.31 \\
1.30 \\
1.31 \\
1.27 \\
1.30 \\
1.23 \\
1.22 \\
1.28 \\
1.34 \\
1.32 \\
1.30 \\
1.32 \\
1.38 \\
1.47 \\
1.38 \\
1.30 \\
1.32\end{array}$ & $\begin{array}{l}7.65 \\
7.86 \\
7.78 \\
7.87 \\
7.62 \\
7.77 \\
7.37 \\
7.36 \\
7.68 \\
8.09 \\
7.94 \\
7.79 \\
7.95 \\
8.27 \\
8.78 \\
8.27 \\
7.77 \\
7.97\end{array}$ & $\begin{array}{l}0.16 \\
0.17 \\
0.16 \\
0.16 \\
0.15 \\
0.16 \\
0.16 \\
0.19 \\
0.16 \\
0.18 \\
0.18 \\
0.17 \\
0.17 \\
0.16 \\
0.18 \\
0.16 \\
0.16 \\
0.17\end{array}$ & $\begin{array}{r}8.08 \\
9.00 \\
9.35 \\
9.04 \\
8.05 \\
9.36 \\
8.48 \\
9.40 \\
9.26 \\
10.51 \\
9.18 \\
9.15 \\
9.21 \\
4.67 \\
4.64 \\
4.48 \\
14.15 \\
15.20\end{array}$ & $\begin{array}{r}11.76 \\
11.66 \\
11.88 \\
11.62 \\
11.62 \\
11.64 \\
11.92 \\
11.52 \\
11.32 \\
11.68 \\
11.61 \\
11.60 \\
11.57 \\
9.98 \\
10.08 \\
9.89 \\
10.98 \\
10.88\end{array}$ & $\begin{array}{l}1.57 \\
1.35 \\
1.66 \\
1.36 \\
1.57 \\
1.20 \\
1.55 \\
1.37 \\
1.46 \\
1.14 \\
1.36 \\
1.38 \\
1.16 \\
2.05 \\
1.90 \\
2.05 \\
1.28 \\
1.23\end{array}$ & $\begin{array}{l}0.25 \\
0.23 \\
0.24 \\
0.31 \\
0.28 \\
0.27 \\
0.21 \\
0.30 \\
0.31 \\
0.20 \\
0.29 \\
0.27 \\
0.24 \\
0.53 \\
0.56 \\
0.51 \\
0.32 \\
0.29\end{array}$ & $\begin{array}{l}0.19 \\
0.07 \\
0.08 \\
0.07 \\
0.18 \\
0.08 \\
0.06 \\
0.07 \\
0.17 \\
0.06 \\
0.08 \\
0.17 \\
0.07 \\
0.19 \\
0.12 \\
0.19 \\
0.07 \\
0.07\end{array}$ & $\begin{array}{r}101.09 \\
101.26 \\
101.40 \\
101.00 \\
98.87 \\
100.53 \\
100.95 \\
10.90 \\
98.42 \\
101.44 \\
100.69 \\
100.88 \\
100.56 \\
98.99 \\
100.62 \\
97.66 \\
100.85 \\
101.27\end{array}$ & $\begin{array}{l}39 \\
32 \\
29 \\
29 \\
38 \\
29 \\
29 \\
30 \\
38 \\
28 \\
32 \\
35 \\
31 \\
51 \\
49 \\
49 \\
33 \\
33\end{array}$ & $\begin{array}{l}19 \\
16 \\
14 \\
14 \\
20 \\
15 \\
15 \\
15 \\
19 \\
13 \\
15 \\
18 \\
15 \\
24 \\
21 \\
23 \\
14 \\
14\end{array}$ & $\begin{array}{l}2 \\
1 \\
1 \\
1 \\
1 \\
1 \\
1 \\
0 \\
1 \\
1 \\
1 \\
2 \\
1 \\
2 \\
0 \\
3 \\
1 \\
1\end{array}$ \\
\hline
\end{tabular}


APPENDIX B (continued).

\begin{tabular}{|c|c|c|c|c|c|c|c|c|c|c|c|c|c|c|c|}
\hline $\begin{array}{l}\text { Core, section, } \\
\text { interval }(\mathrm{cm})\end{array}$ & $\mathrm{Sr}$ & $\mathrm{Rb}$ & $\mathrm{Ba}$ & $\mathrm{Ni}$ & $\mathrm{Cr}$ & V & $\mathrm{Ce}$ & Mg\# & $\mathrm{CaO} / \mathrm{Al}_{2} \mathrm{O}_{3}$ & $\mathrm{Na}_{2} \mathrm{O} / \mathrm{CaO}$ & $\mathrm{Ti} / \mathrm{Zr}$ & $\mathrm{Y} / \mathrm{Zr}$ & $\mathrm{FeO}^{*} / \mathrm{MgO}$ & $\mathrm{CaO} / \mathrm{TiO}_{2}$ & $\mathrm{Al}_{2} \mathrm{O}_{3} / \mathrm{TiO}_{2}$ \\
\hline $135-835 \mathrm{~B}-4 \mathrm{R}-1,16-20^{\circ}$ & 135 & 4 & 41 & 69 & 170 & ND & 9 & 63.00 & 0.77 & 0.14 & 153.20 & 0.51 & 1.05 & 10.94 & 14.29 \\
\hline $135-835 \mathrm{~B}-6 \mathrm{R}-1,32-37^{*}$ & 130 & 5 & 42 & 78 & 179 & ND & 7 & 65.00 & 0.78 & 0.14 & 148.50 & 0.50 & 0.96 & 11.83 & 15.11 \\
\hline 135-835B-6R-1, 114-117 & 135 & 5 & 64 & 60 & 127 & ND & 6 & 58.70 & 0.76 & 0.18 & 150.50 & 0.51 & 1.25 & 10.02 & 13.15 \\
\hline $135-835 \mathrm{~B}-7 \mathrm{R}-1,40-44^{\circ}$ & 131 & 3 & 29 & 89 & 179 & ND & 9 & 64.30 & 0.77 & 0.14 & 147.90 & 0.49 & 0.99 & 11.56 & 14.95 \\
\hline 135-835B-7R-2, 75-84, & 129 & 2 & ND & 70 & ND & ND & ND & 65.70 & 0.78 & 0.18 & 94.00 & 0.49 & 0.93 & 15.34 & 19.65 \\
\hline $135-835 \mathrm{~B}-7 \mathrm{R}-2,84-89^{*}$ & 131 & 1 & 36 & 73 & 155 & ND & 7 & 65.80 & 0.75 & 0.17 & 151.90 & 0.49 & 0.93 & 10.67 & 14.23 \\
\hline $135-836 \mathrm{~A}-3 \mathrm{H}-2,83-85$ & 135 & 4 & 38 & 17 & ND & 404 & ND & 40.60 & 0.52 & 0.34 & 115.00 & 0.49 & 2.61 & 6.06 & 11.67 \\
\hline $135-836 \mathrm{~A}-3 \mathrm{H}-3,33-43$ & 142 & 5 & ND & 13 & ND & ND & ND & 40.40 & 0.60 & 0.35 & 96.40 & 0.41 & 2.63 & 6.77 & 11.21 \\
\hline $135-836 \mathrm{~A}-3 \mathrm{H}-4,75-150^{*}$ & 138 & 4 & 89 & 8 & 9 & ND & 13 & 39.30 & 0.56 & 0.36 & 89.20 & 0.44 & 2.75 & 6.95 & 12.48 \\
\hline $135-836 \mathrm{~A}-3 \mathrm{H}-4,88-100$ & 141 & 3 & ND & 15 & ND & ND & ND & 40.70 & 0.59 & 0.38 & 83.90 & 0.44 & 2.60 & 7.36 & 12.56 \\
\hline $135-836 \mathrm{~A}-3 \mathrm{H}-7,54-55$ & 140 & 0.1 & 17 & 111 & ND & 216 & ND & 69.30 & 0.68 & 0.15 & 88.00 & 0.40 & 0.79 & 18.88 & 27.80 \\
\hline $135-836 \mathrm{~A}-4 \mathrm{H}-\mathrm{CC}, 0-13$ & 152 & 1 & 19 & 112 & ND & 227 & ND & 67.90 & 0.74 & 0.15 & 96.90 & 0.49 & 0.84 & 18.01 & 24.39 \\
\hline $135-836 \mathrm{~A}-3 \mathrm{H}-\mathrm{CC}, 0-9$ & 150 & 0.2 & 18 & 114 & ND & 219 & ND & 68.20 & 0.76 & 0.15 & 91.20 & 0.42 & 0.83 & 18.52 & 24.40 \\
\hline $135-836 \mathrm{~B}-5 \mathrm{X}-1,3-9^{*}$ & 155 & 3 & 20 & 117 & 344 & ND & 11 & 69.20 & 0.85 & 0.12 & 104.60 & 0.42 & 0.79 & 18.80 & 22.16 \\
\hline 135-836B-3R-1, 68-70. & 356 & 7 & 11 & 103 & 342 & ND & 10 & 66.20 & 0.87 & 0.14 & 80.30 & 0.32 & 0.91 & 19.28 & 22.12 \\
\hline 135-836B-3R-2, 32-38. & 288 & 3 & 14 & 139 & 318 & ND & 4 & 65.60 & 0.92 & 0.13 & 89.40 & 0.34 & 0.94 & 18.80 & 20.39 \\
\hline $135-836 \mathrm{~B}-3 \mathrm{R}-2,96-100^{\circ}$ & 187 & 0 & 16 & 118 & 352 & ND & 6 & 68.60 & 0.87 & 0.12 & 102.60 & 0.38 & 0.82 & 0.19 & 0.21 \\
\hline $135-836 \mathrm{~A}-7 \mathrm{X}-1,15-22$. & 201 & 1 & 21 & 126 & ND & 172 & ND & 68.30 & 0.84 & 0.16 & 93.10 & 0.38 & 0.83 & 18.70 & 22.15 \\
\hline 135-836A-7X-1, 37-42 & 228 & 0 & 13 & 114 & 280 & ND & 6 & 69.40 & 0.84 & 0.14 & 99.00 & 0.37 & 0.79 & 18.33 & 21.70 \\
\hline $135-836 \mathrm{~A}-8 \mathrm{X}-1,29-34$ & 146 & 2 & 33 & 31 & ND & 368 & ND & 51.70 & 0.57 & 0.23 & 106.70 & 0.48 & 1.67 & 10.16 & 17.83 \\
\hline 135-836B-5R-1, 67-72 & 155 & 1 & 20 & 112 & ND & 187 & ND & 70.50 & 0.81 & 0.17 & 90.60 & 0.42 & 0.74 & 21.22 & 26.17 \\
\hline 135-836B-5R-2, 65-74. & 152 & 0.3 & ND & 91 & ND & ND & ND & 69.60 & 0.90 & 0.16 & 89.30 & 0.37 & 0.78 & 18.66 & 20.84 \\
\hline 135-836B-5R-2, 84-90. & 143 & 1 & 21 & 113 & 293 & ND & 9 & 69.80 & 0.80 & 0.14 & 107.00 & 0.41 & 0.77 & 17.41 & 21.71 \\
\hline $135-836 \mathrm{~A}-9 \mathrm{X}-2,40-47^{\circ}$ & 143 & 1 & 18 & 106 & 284 & ND & 7 & 71.10 & 0.81 & 0.14 & 105.30 & 0.44 & 0.72 & 18.65 & 22.90 \\
\hline $135-836 \mathrm{~A}-9 \mathrm{X}-2,29-34$ & 153 & 1 & 25 & 104 & ND & 181 & ND & 70.30 & 0.82 & 0.16 & 89.90 & 0.38 & 0.75 & 18.65 & 22.76 \\
\hline 135-836B-5R-3, 120-124 & 175 & 1 & 17 & 127 & ND & 168 & ND & 69.30 & 0.80 & 0.17 & 88.70 & 0.42 & 0.79 & 18.45 & 23.18 \\
\hline 135-836B-6R-2, 25-29. & 146 & 1 & 18 & 116 & ND & 173 & ND & 70.00 & 0.80 & 0.16 & 86.90 & 0.41 & 0.76 & 18.27 & 22.96 \\
\hline $135-836 \mathrm{~B}-7 \mathrm{R}-1,32-36^{*}$ & 153 & 5 & 53 & 28 & 19 & ND & 13 & 50.00 & 0.69 & 0.21 & 119.90 & 0.46 & 1.78 & 9.40 & 13.54 \\
\hline 135-836B-7R-1, 41-47 & 147 & 8 & 35 & 24 & ND & 366 & ND & 49.80 & 0.61 & 0.21 & 106.40 & 0.45 & 1.80 & 9.70 & 15.82 \\
\hline 135-836B-7R-2, 35-40 & 147 & 5 & 30 & 27 & ND & 365 & ND & 51.40 & 0.65 & 0.22 & 105.90 & 0.43 & 1.69 & 10.27 & 15.86 \\
\hline 135-836B-7R-2, 56-62 & 319 & 2 & 19 & 120 & ND & 157 & ND & 69.60 & 0.85 & 0.17 & 98.10 & 0.46 & 0.78 & 19.14 & 22.51 \\
\hline 135-836B-8R-1, 11-17. & 146 & 5 & 30 & 28 & ND & 350 & ND & 52.20 & 0.67 & 0.21 & 109.70 & 0.44 & 1.63 & 10.23 & 15.20 \\
\hline $135-836 \mathrm{~B}-9 \mathrm{M}-1,45-32^{\circ}$ & 148 & 5 & 53 & 27 & 15 & ND & 13 & 49.00 & 0.69 & 0.22 & 117.90 & 0.45 & 1.85 & 8.92 & 12.97 \\
\hline 135-837B-2R-1, 24-30 & 155 & 9 & 75 & 2 & 0 & ND & 17 & 37.50 & 0.54 & 0.33 & 107.10 & 0.47 & 2.97 & 5.91 & 10.87 \\
\hline $135-837 \mathrm{~B}-2 \mathrm{R}-1,30-36$ & 158 & 8 & ND & 5 & ND & ND & ND & 37.90 & 0.52 & 0.36 & 99.40 & 0.44 & 2.92 & 5.95 & 11.35 \\
\hline 135-837B-3R-1, 34-39 & 167 & 9 & ND & 6 & ND & ND & ND & 38.00 & 0.54 & 0.34 & 97.50 & 0.45 & 2.91 & 6.10 & 11.40 \\
\hline $135-837 \mathrm{~B}-3 \mathrm{R}-1,137-140$ & 160 & 10 & ND & 5 & ND & ND & ND & 38.20 & 0.50 & 0.36 & 98.90 & 0.44 & 2.89 & 6.10 & 12.10 \\
\hline 135-837B-4R-1, 36-41. & 165 & 14 & ND & 5 & ND & ND & ND & 38.50 & 0.53 & 0.38 & 100.90 & 0.44 & 2.85 & 6.11 & 11.53 \\
\hline $135-837 \mathrm{~B}-5 \mathrm{R}-1,62-69^{\circ}$ & 167 & 12 & 98 & 5 & 0 & ND & 7 & 38.60 & 0.54 & 0.32 & 107.30 & 0.47 & 2.84 & 5.94 & 10.93 \\
\hline $135-839 \mathrm{~B}-12 \mathrm{R}-1,103-108$ & 154 & 4 & ND & 107 & ND & ND & ND & 65.30 & 0.70 & 0.13 & 92.20 & 0.49 & 0.95 & 19.60 & 27.82 \\
\hline $135-839 \mathrm{~A}-24 \mathrm{X}-1,0-6^{*}$ & 148 & 5 & 78 & 126 & 618 & ND & 5 & 67.10 & 0.77 & 0.12 & 121.80 & 0.50 & 0.87 & 17.94 & 23.17 \\
\hline 135-839B-12R-2, 25-32. & 143 & 11 & 45 & 143 & 637 & ND & 8 & 68.20 & 0.78 & 0.14 & 124.00 & 0.48 & 0.83 & 19.80 & 25.25 \\
\hline 135-839B-13R-2, 72-77 & 143 & 13 & 59 & 130 & 644 & ND & 7 & 67.20 & 0.77 & 0.12 & 128.20 & 0.48 & 0.87 & 18.74 & 24.27 \\
\hline $135-839 \mathrm{~B}-13 \mathrm{R}-2,106-110$ & 150 & 7 & ND & 114 & ND & ND & ND & 65.30 & 0.77 & 0.14 & 97.80 & 0.53 & 0.95 & 18.74 & 24.40 \\
\hline 135-839B-13R-4, 22-26 & 141 & 11 & 70 & 145 & 666 & ND & 6 & 68.20 & 0.78 & 0.10 & 124.00 & 0.52 & 0.83 & 19.40 & 24.97 \\
\hline $135-839 \mathrm{~B}-14 \mathrm{R}-1,128-135^{\circ}$ & 149 & 10 & 59 & 109 & 347 & ND & 8 & 67.20 & 0.77 & 0.13 & 124.00 & 0.52 & 0.87 & 19.87 & 25.90 \\
\hline 135-839B-15R-1, 34-39 & 145 & 14 & 63 & 139 & 503 & ND & 9 & 69.50 & 0.77 & 0.12 & 129.90 & 0.50 & 0.78 & 17.72 & 23.05 \\
\hline 135-839B-15R-2, 51-56 . & 144 & 6 & ND & 132 & ND & ND & ND & 68.20 & 0.77 & 0.13 & 97.80 & 0.50 & 0.83 & 18.26 & 23.61 \\
\hline $135-839 \mathrm{~B}-15 \mathrm{R}-4,95-100^{\circ}$. & 139 & 8 & 55 & 166 & 945 & ND & 6 & 69.80 & 0.81 & 0.10 & 128.50 & 0.46 & 0.77 & 19.47 & 24.08 \\
\hline 135-839B-16R-1, 106-111 & 146 & 7 & 77 & 136 & 686 & ND & 5 & 67.30 & 0.78 & 0.12 & 123.70 & 0.47 & 0.86 & 17.59 & 22.64 \\
\hline 135-839B-16R-2, 7-10 & 146 & 5 & ND & 127 & ND & ND & ND & 67.70 & 0.71 & 0.12 & 101.10 & 0.51 & 0.85 & 19.66 & 27.66 \\
\hline $135-839 \mathrm{~B}-16 \mathrm{R}-2,15-16^{\circ}$ & 145 & 5 & 54 & 135 & 566 & ND & 8 & 67.40 & 0.78 & 0.10 & 121.80 & 0.48 & 0.86 & 18.37 & 23.56 \\
\hline 135-839B-18R-1, 48-52. & 190 & 8 & ND & 16 & ND & ND & ND & 50.20 & 0.54 & 0.21 & 96.40 & 0.47 & 1.77 & 12.17 & 22.41 \\
\hline $135-839 \mathrm{~B}-18 \mathrm{R}-1,54-60^{\circ}$ & 191 & 8 & 85 & 15 & 7 & ND & 12 & 48.50 & 0.63 & 0.19 & 110.10 & 0.43 & 1.89 & 11.20 & 17.87 \\
\hline 135-839B-19R-1, 5-8 & 191 & 7 & ND & 18 & ND & ND & ND & 49.10 & 0.56 & 0.21 & 102.80 & 0.47 & 1.85 & 11.77 & 20.90 \\
\hline $135-839 \mathrm{~B}-19 \mathrm{R}-1,50-56^{\circ}$ & 137 & 4 & 62 & 283 & 1229 & ND & 12 & 76.40 & 0.86 & 0.12 & 105.40 & 0.42 & 0.55 & 18.93 & 21.98 \\
\hline 135-839B-20R-1, 74-80 & 163 & 5 & 55 & 320 & 1398 & ND & 9 & 77.30 & 0.87 & 0.11 & 103.50 & 0.42 & 0.52 & 19.09 & 21.89 \\
\hline
\end{tabular}


APPENDIX B (continued).

\begin{tabular}{|c|c|c|c|c|c|c|c|c|c|c|c|c|c|c|c|c|c|c|}
\hline $\begin{array}{l}\text { Core, section, } \\
\text { interval }(\mathrm{cm})\end{array}$ & Unit & $\begin{array}{l}\text { Depth } \\
\text { (mbsf) }\end{array}$ & $\mathrm{SiO}_{2}$ & $\mathrm{TiO}_{2}$ & $\mathrm{Al}_{2} \mathrm{O}_{3}$ & $\mathrm{FeO}^{\circ}$ & $\mathrm{Fe}_{2} \mathrm{O}_{3}$ & $\mathrm{FeO}$ & $\mathrm{MnO}$ & $\mathrm{MgO}$ & $\mathrm{CaO}$ & $\mathrm{Na}_{2} \mathrm{O}$ & $\mathrm{K}_{2} \mathrm{O}$ & $\mathrm{P}_{2} \mathrm{O}_{5}$ & Sum & $\mathrm{Zr}$ & $\mathrm{Y}$ & $\mathrm{Nb}$ \\
\hline $135-839 \mathrm{~B}-23 \mathrm{R}-1,24-27^{\circ}$ & 3 & 314.84 & 50.43 & 0.59 & 12.66 & 9.32 & 1.36 & 8.10 & 0.17 & 14.86 & 10.92 & 1.21 & 0.26 & 0.07 & 101.54 & 33 & 15 & 1 \\
\hline $135-839 \mathrm{~B}-25 \mathrm{R}-1,17-22$ & 3 & 334.17 & 46.77 & 0.46 & 12.17 & 8.64 & 1.26 & 7.51 & 0.16 & 19.26 & 8.97 & 1.19 & 0.25 & 0.14 & 98.00 & 38 & 15 & $i$ \\
\hline 135-839B-26R-1, $23-29^{\circ}$ & 4 & 343.83 & 51.64 & 0.57 & 14.33 & 8.48 & 1.23 & 7.37 & 0.17 & 9.72 & 13.64 & 1.15 & 0.22 & 0.04 & 100.92 & 27 & 15 & 1 \\
\hline $135-839 \mathrm{~B}-27 \mathrm{R}-1,15-19^{\circ}$ & 5 & 353.45 & 54.15 & 0.85 & 16.55 & 9.95 & 1.44 & 8.65 & 0.19 & 4.36 & 9.85 & 1.99 & 0.65 & 0.13 & 99.78 & 52 & 20 & i \\
\hline 135-839B-27R-1, 21-24". & 6 & 353.51 & 50.45 & 0.58 & 12.75 & 8.91 & 1.29 & 7.75 & 0.17 & 13.71 & 11.00 & 1.71 & 0.29 & 0.07 & 100.63 & 33 & 14 & 1 \\
\hline $135-839 \mathrm{~B}-27 \mathrm{R}-1,38-42^{\circ}$ & 7 & 353.68 & 55.02 & 0.87 & 16.46 & 10.11 & 1.47 & 8.79 & 0.20 & 4.35 & 9.80 & 1.96 & 0.78 & 0.13 & 100.80 & 52 & 21 & 1 \\
\hline $135-839 \mathrm{~B}-28 \mathrm{R}-1,24-29^{*}$ & 9 & 363.14 & 54.57 & 0.86 & 16.39 & 10.04 & 1.46 & 8.73 & 0.19 & 4.36 & 9.89 & 2.33 & 0.64 & 0.13 & 100.53 & 53 & 21 & 1 \\
\hline 135-839B-30R-1, 74-79 & 9 & 382.94 & 54.68 & 0.85 & 16.50 & 10.13 & 1.47 & 8.81 & 0.18 & 4.34 & 9.77 & 2.00 & 0.68 & 0.14 & 100.40 & 54 & 20 & $\mathrm{i}$ \\
\hline $135-839 \mathrm{~B}-34 \mathrm{R}-1,15-20^{\circ}$ & 9 & 421.05 & 53.41 & 0.81 & 16.84 & 9.44 & 1.37 & 8.21 & 0.18 & 4.77 & 10.50 & 1.94 & 0.41 & 0.09 & 99.42 & 45 & 20 & 1 \\
\hline $135-839 \mathrm{~B}-35 \mathrm{R}-1,0-6$ & 9 & 430.30 & 52.40 & 0.74 & 20.14 & 9.03 & 1.31 & 7.85 & 0.15 & 4.75 & 10.30 & 2.01 & 0.46 & 0.17 & 100.15 & 45 & 20 & 5 \\
\hline $135-839 \mathrm{~B}-35 \mathrm{R}-1,29-36$ & 9 & 430.59 & 53.75 & 0.78 & 18.46 & 9.40 & 1.37 & 8.17 & 0.18 & 4.85 & 10.50 & 1.83 & 0.48 & 0.18 & 100.39 & 48 & 22 & 2 \\
\hline $135-839 \mathrm{~B}-35 \mathrm{R}-1,66-70$ & 9 & 430.96 & 53.51 & 0.78 & 18.06 & 9.33 & 1.36 & 8.11 & 0.17 & 4.79 & 10.54 & 1.84 & 0.45 & 0.17 & 99.64 & 49 & 22 & 1 \\
\hline $135-839 \mathrm{~B}-36 \mathrm{R}-1,21-24$ & 9 & 439.81 & 53.02 & 0.76 & 17.92 & 9.11 & 1.32 & 7.92 & 0.16 & 4.81 & 10.38 & 1.85 & 0.47 & 0.18 & 98.65 & 48 & 22 & 2 \\
\hline $135-839 \mathrm{~B}-36 \mathrm{R}-1,26-31^{\circ}$ & 9 & 439.86 & 53.76 & 0.80 & 17.16 & 9.56 & 1.39 & 8.31 & 0.18 & 4.95 & 10.60 & 1.90 & 0.45 & 0.08 & 100.47 & 44 & 21 & 2 \\
\hline $135-839 \mathrm{~B}-37 \mathrm{R}-1,50-56^{\circ}$ & 9 & 449.70 & 54.06 & 0.82 & 17.14 & 9.59 & 1.39 & 8.34 & 0.18 & 4.86 & 10.56 & 1.80 & 0.44 & 0.10 & 100.60 & 44 & 20 & 1 \\
\hline $135-839 B-41 R-1,5-10^{\circ}$ & 9 & 487.55 & 53.41 & 0.81 & 16.12 & 10.24 & 1.49 & 8.90 & 0.19 & 5.76 & 10.80 & 1.72 & 0.39 & 0.08 & 100.64 & 45 & 20 & i \\
\hline
\end{tabular}


APPENDIX B (continued).

\begin{tabular}{|c|c|c|c|c|c|c|c|c|c|c|c|c|c|c|c|}
\hline $\begin{array}{l}\text { Core, section, } \\
\text { interval }(\mathrm{cm})\end{array}$ & $\mathrm{Sr}$ & $\mathrm{Rb}$ & $\mathrm{Ba}$ & $\mathrm{Ni}$ & $\mathrm{Cr}$ & V & $\mathrm{Ce}$ & Mg\# & $\mathrm{CaO} / \mathrm{Al}_{2} \mathrm{O}_{3}$ & $\mathrm{Na}_{2} \mathrm{O} / \mathrm{CaO}$ & $\mathrm{Ti} / \mathrm{Zr}$ & $\mathrm{Y} / \mathrm{Zr}$ & $\mathrm{FeO}^{*} / \mathrm{MgO}$ & $\mathrm{CaO} / \mathrm{TiO}_{2}$ & $\mathrm{Al}_{2} \mathrm{O}_{3} / \mathrm{TiO}_{2}$ \\
\hline $135-839 \mathrm{~B}-23 \mathrm{R}-1,24-27^{\circ}$ & 137 & 4 & 54 & 320 & 1740 & ND & 10 & 76.60 & 0.86 & 0.11 & 107.20 & 0.46 & 0.55 & 18.51 & 21.46 \\
\hline $135-839 \mathrm{~B}-25 \mathrm{R}-1,17-22$ & 120 & 4 & ND & 384 & ND & ND & ND & 82.00 & 0.74 & 0.13 & 72.60 & 0.40 & 0.39 & 19.50 & 26.46 \\
\hline $135-839 \mathrm{~B}-26 \mathrm{R}-1,23-29^{\circ}$ & 117 & 3 & 44 & 92 & 445 & ND & 6 & 70.10 & 0.95 & 0.08 & 126.60 & 0.56 & 0.76 & 23.93 & 25.14 \\
\hline $135-839 \mathrm{~B}-27 \mathrm{R}-1,15-19^{\circ}$ & 217 & 9 & 114 & 12 & 3 & ND & 9 & 47.30 & 0.60 & 0.20 & 98.00 & 0.39 & 1.98 & 11.59 & 19.47 \\
\hline $135-839 \mathrm{~B}-27 \mathrm{R}-1,21-24^{\circ}$ & 140 & 5 & 58 & 258 & 1391 & ND & 2 & 75.90 & 0.86 & 0.16 & 105.40 & 0.42 & 0.57 & 18.97 & 21.98 \\
\hline $135-839 \mathrm{~B}-27 \mathrm{R}-1,38-42^{\circ}$ & 215 & 12 & 127 & 11 & 4 & ND & 15 & 46.90 & 0.60 & 0.20 & 100.30 & 0.40 & 2.02 & 11.26 & 18.92 \\
\hline $135-839 \mathrm{~B}-28 \mathrm{R}-1,24-29^{\circ}$ & 219 & 9 & 118 & 11 & 1 & ND & 14 & 47.10 & 0.60 & 0.24 & 97.30 & 0.40 & 2.00 & 11.50 & 19.06 \\
\hline $135-839 \mathrm{~B}-30 \mathrm{R}-1,74-79^{\circ}$ & 218 & 10 & 123 & 11 & 0 & ND & 11 & 46.80 & 0.59 & 0.20 & 94.40 & 0.37 & 2.03 & 11.49 & 19.41 \\
\hline $135-839 \mathrm{~B}-34 \mathrm{R}-1,15-20^{\circ}$ & 185 & 5 & 117 & 20 & 22 & ND & 8 & 50.90 & 0.62 & 0.18 & 107.90 & 0.44 & 1.72 & 12.96 & 20.79 \\
\hline $135-839 \mathrm{~B}-35 \mathrm{R}-1,0-6$ & 178 & 6 & ND & 24 & ND & ND & ND & 51.90 & 0.51 & 0.20 & 98.60 & 0.44 & 1.65 & 13.92 & 27.22 \\
\hline $135-839 \mathrm{~B}-35 \mathrm{R}-1,29-36$ & 190 & 5 & ND & 21 & ND & ND & ND & 51.40 & 0.57 & 0.17 & 97.40 & 0.46 & 1.69 & 13.46 & 23.67 \\
\hline $135-839 \mathrm{~B}-35 \mathrm{R}-1,66-70$ & 185 & 5 & ND & 23 & ND & ND & ND & 51.30 & 0.58 & 0.17 & 95.40 & 0.45 & 1.69 & 13.51 & 23.15 \\
\hline $135-839 \mathrm{~B}-36 \mathrm{R}-1,21-24$ & 183 & 7 & ND & 22 & ND & ND & ND & 52.00 & 0.58 & 0.18 & 94.90 & 0.46 & 1.65 & 13.66 & 23.58 \\
\hline $135-839 \mathrm{~B}-36 \mathrm{R}-1,26-31^{*}$ & 185 & 6 & 84 & 20 & 25 & ND & 15 & 51.50 & 0.62 & 0.18 & 109.00 & 0.48 & 1.68 & 13.25 & 21.45 \\
\hline $135-839 \mathrm{~B}-37 \mathrm{R}-1,50-56^{\circ}$ & 183 & 6 & 96 & 21 & 24 & ND & 7 & 50.90 & 0.62 & 0.17 & 111.70 & 0.46 & 1.72 & 12.88 & 20.90 \\
\hline $135-839 \mathrm{~B}-41 \mathrm{R}-1,5-10^{\circ}$ & 185 & 5 & 72 & 20 & 10 & ND & 10 & 53.60 & 0.67 & 0.16 & 107.90 & 0.44 & 1.55 & 13.33 & 19.90 \\
\hline
\end{tabular}

Notes: An asterisk $(*)$ indicates shipboard XRF data. $\mathrm{ND}=$ not determined. 
APPENDIX C

Microprobe Analyses of Plagioclase Minerals, Sites 834 through 839

\begin{tabular}{|c|c|c|c|c|c|c|c|c|c|}
\hline $\begin{array}{l}\text { Core, section, } \\
\text { interval }(\mathrm{cm})\end{array}$ & Unit & Form & $\mathrm{SiO}_{2}$ & $\mathrm{Al}_{2} \mathrm{O}_{3}$ & $\mathrm{CaO}$ & $\mathrm{Na}_{2} \mathrm{O}$ & $\mathrm{K}_{2} \mathrm{O}$ & $\mathrm{FeO}^{*}$ & $\mathrm{MgO}$ \\
\hline $135-834 \mathrm{~A}-12 \mathrm{X}-\mathrm{CC}, 2$ & 1 & MIC & 49.35 & 32.13 & 14.62 & 2.87 & 0.03 & 0.53 & 0.18 \\
\hline $135-834 \mathrm{~A}-12 \mathrm{X}-\mathrm{CC}, 2$ & 1 & MIC & 49.62 & 31.70 & 14.44 & 3.11 & 0.05 & 0.55 & 0.24 \\
\hline $135-834 \mathrm{~A}-12 \mathrm{X}-\mathrm{CC}, 2$ & 1 & PHC & 50.25 & 31.62 & 14.39 & 3.23 & 0.03 & 0.54 & 0.20 \\
\hline $135-834 \mathrm{~A}-12 \mathrm{X}-\mathrm{CC}, 2$ & 1 & SKEL & 49.44 & 32.14 & 14.94 & 2.85 & 0.00 & 0.57 & 0.17 \\
\hline $135-834 \mathrm{~A}-12 \mathrm{X}-\mathrm{CC} .2$ & 1 & PHC & 46.69 & 33.97 & 16.77 & 1.74 & 0.01 & 0.38 & 0.13 \\
\hline $135-834 \mathrm{~A}-12 \mathrm{X}-\mathrm{CC}, 2$ & 1 & PHR & 48.37 & 32.47 & 15.29 & 2.46 & 0.01 & 0.41 & 0.16 \\
\hline $135-834 \mathrm{~A}-13 \mathrm{X}-1,24$ & $2 \mathrm{~A}$ & MIC & 51.16 & 30.77 & 13.83 & 3.68 & 0.02 & 0.82 & 0.19 \\
\hline $135-834 \mathrm{~A}-13 \mathrm{X}-1,24$ & $2 \mathrm{~A}$ & MIC & 50.12 & 31.30 & 14.24 & 3.27 & 0.02 & 0.65 & 0.19 \\
\hline $135-834 \mathrm{~A}-13 \mathrm{X}-1,24$ & $2 \mathrm{~A}$ & PHC & 52.16 & 29.76 & 12.45 & 4.15 & 0.04 & 0.82 & 0.19 \\
\hline $135-834 \mathrm{~A}-13 \mathrm{X}-1,24$ & $2 \mathrm{~A}$ & MIC & 52.19 & 29.00 & 12.09 & 4.57 & 0.05 & 0.89 & 0.21 \\
\hline $135-834 \mathrm{~A}-13 \mathrm{X}-1,24$ & $2 \mathrm{~A}$ & MIC & 54.15 & 27.85 & 10.54 & 5.39 & 0.07 & 1.10 & 0.22 \\
\hline $135-834 \mathrm{~B}-8 \mathrm{R}-1,110$ & $2 \mathrm{~A}$ & PHC & 51.71 & 31.35 & 13.49 & 3.49 & 0.02 & 0.61 & 0.17 \\
\hline $135-834 \mathrm{~B}-8 \mathrm{R}-1,110$ & $2 \mathrm{~A}$ & PHR & 50.99 & 31.82 & 13.68 & 3.18 & 0.00 & 0.64 & 0.16 \\
\hline $135-834 \mathrm{~B}-8 \mathrm{R}-1,110$ & $2 \mathrm{~A}$ & PHC & 52.78 & 30.52 & 12.12 & 4.19 & 0.06 & 0.58 & 0.10 \\
\hline $135-834 \mathrm{~B}-8 \mathrm{R}-1,110$ & $2 \mathrm{~A}$ & PHR & 57.75 & 27.14 & 8.62 & 6.33 & 0.09 & 0.73 & 0.03 \\
\hline $135-834 \mathrm{~A}-14 \mathrm{X}-6,7$ & $2 \mathrm{~B}$ & MIC & 50.35 & 30.96 & 13.82 & 3.50 & 0.04 & 0.60 & 0.16 \\
\hline $135-834 \mathrm{~A}-14 \mathrm{X}-6,7$ & $2 \mathrm{~B}$ & PHC & 50.75 & 30.36 & 13.61 & 3.74 & 0.05 & 0.73 & 0.20 \\
\hline $135-834 \mathrm{~A}-14 \mathrm{X}-6,7$ & $2 \mathrm{~B}$ & PHC & 50.10 & 31.21 & 14.12 & 3.40 & 0.03 & 0.65 & 0.17 \\
\hline $135-834 \mathrm{~A}-20 \mathrm{X}-2,81$ & 5 & PHC & 45.70 & 34.25 & 17.32 & 1.54 & 0.00 & 0.46 & 0.15 \\
\hline $135-834 \mathrm{~A}-20 \mathrm{X}-2,81$ & 5 & PHR & 54.97 & 27.92 & 10.02 & 5.79 & 0.05 & 0.87 & 0.05 \\
\hline $135-834 \mathrm{~A}-20 \mathrm{X}-2,81$ & 5 & PHC & 47.97 & 32.55 & 15.94 & 2.32 & 0.04 & 0.54 & 0.25 \\
\hline $135-834 \mathrm{~A}-20 \mathrm{X}-2,81$ & 5 & PHC & 46.02 & 34.16 & 16.96 & 1.68 & 0.00 & 0.38 & 0.13 \\
\hline $135-834 \mathrm{~A}-20 \mathrm{X}-2,81$ & 5 & PHI & 46.48 & 33.65 & 16.68 & 1.92 & 0.02 & 0.47 & 0.16 \\
\hline $135-834 \mathrm{~A}-20 \mathrm{X}-2,81$ & 5 & PHR & 46.79 & 34.02 & 16.85 & 1.71 & 0.02 & 0.45 & 0.15 \\
\hline $135-834 \mathrm{~A}-20 \mathrm{X}-2,81$ & 5 & OPHI & 49.61 & 31.55 & 14.52 & 3.10 & 0.03 & 0.56 & 0.18 \\
\hline $135-834 \mathrm{~A}-20 \mathrm{X}-2,81$ & 5 & OPHI & 49.89 & 31.44 & 14.01 & 3.39 & 0.02 & 0.57 & 0.16 \\
\hline $135-834 \mathrm{~A}-20 \mathrm{X}-2,81$ & 5 & OPHI & 55.69 & 27.58 & 9.77 & 5.72 & 0.07 & 0.77 & 0.09 \\
\hline $135-834 \mathrm{~B}-10 \mathrm{R}-1,37$ & 5 & $\mathrm{CH}$ & 47.95 & 32.55 & 15.97 & 2.30 & 0.03 & 0.62 & 0.13 \\
\hline $135-834 \mathrm{~B}-10 \mathrm{R}-1,37$ & 5 & $\mathrm{CH}$ & 49.55 & 31.65 & 15.01 & 3.08 & 0.03 & 0.51 & 0.15 \\
\hline $135-834 \mathrm{~B}-10 \mathrm{R}-1,37$ & 5 & $\mathrm{CH}$ & 50.30 & 29.68 & 12.74 & 3.53 & 0.07 & 1.69 & 1.17 \\
\hline $135-834 \mathrm{~B}-10 \mathrm{R}-1,37$ & 5 & GRNDC & 50.48 & 31.12 & 13.76 & 3.44 & 0.03 & 0.53 & 0.16 \\
\hline $135-834 \mathrm{~B}-10 \mathrm{R}-1,37$ & 5 & GRNDR & 54.99 & 27.35 & 9.64 & 5.9 & 0.08 & 0.63 & 0.06 \\
\hline $135-834 \mathrm{~B}-10 \mathrm{R}-1,37$ & 5 & PHC & 47.96 & 30.78 & 13.91 & 2.66 & 0.01 & 1.63 & 1.58 \\
\hline $135-834 \mathrm{~B}-10 \mathrm{R}-1,37$ & 5 & PHR & 58.40 & 25.81 & 7.38 & 7.05 & 0.12 & 0.59 & 0.03 \\
\hline $135-834 \mathrm{~B}-14 \mathrm{R}-1,32$ & 6 & MIC & 51.57 & 29.62 & 12.44 & 3.92 & 0.11 & 0.68 & 0.17 \\
\hline $135-834 \mathrm{~B}-14 \mathrm{R}-1,32$ & 6 & MIC & 52.92 & 28.85 & 11.83 & 4.71 & 0.04 & 0.96 & 0.25 \\
\hline $135-834 \mathrm{~B}-14 \mathrm{R}-1,32$ & 6 & GLOM & 53.68 & 28.89 & 11.70 & 4.87 & 0.03 & 0.70 & 0.09 \\
\hline $135-834 \mathrm{~B}-14 \mathrm{R}-1,32$ & 6 & GLOMR & 51.85 & 30.48 & 13.36 & 3.96 & 0.05 & 0.66 & 0.13 \\
\hline $135-834 \mathrm{~B}-15 \mathrm{R}-1,43$ & 6 & MIC & 52.55 & 31.14 & 13.15 & 3.75 & 0.01 & 0.79 & 0.15 \\
\hline $135-834 \mathrm{~B}-15 \mathrm{R}-1,43$ & 6 & GLOM & 51.24 & 30.96 & 13.16 & 3.72 & 0.02 & 0.51 & 0.13 \\
\hline $135-834 \mathrm{~B}-15 \mathrm{R}-1,43$ & 6 & GLOM & 51.90 & 31.51 & 13.40 & 3.63 & 0.02 & 0.62 & 0.14 \\
\hline $135-834 \mathrm{~B}-15 \mathrm{R}-1,43$ & 6 & PHC & 53.21 & 30.02 & 11.99 & 4.34 & 0.02 & 0.59 & 0.14 \\
\hline $135-834 \mathrm{~B}-15 \mathrm{R}-1,43$ & 6 & PHR & 51.96 & 31.32 & 13.01 & 3.77 & 0.02 & 0.57 & 0.16 \\
\hline $135-834 \mathrm{~B}-15 \mathrm{R}-2,35$ & 6 & PHC & 51.82 & 29.58 & 12.56 & 4.06 & 0.03 & 0.69 & 0.17 \\
\hline $135-834 \mathrm{~B}-15 \mathrm{R}-2,35$ & 6 & PHC & 52.41 & 29.68 & 12.43 & 4.25 & 0.02 & 0.60 & 0.13 \\
\hline $135-834 \mathrm{~B}-15 \mathrm{R}-2,35$ & 6 & PHR & 52.29 & 29.89 & 12.19 & 4.27 & 0.03 & 0.66 & 0.19 \\
\hline $135-834 \mathrm{~B}-15 \mathrm{R}-2,35$ & 6 & MIC & 51.18 & 30.07 & 13.02 & 3.75 & 0.01 & 0.66 & 0.13 \\
\hline $135-834 \mathrm{~B}-15 \mathrm{R}-2,56$ & 6 & PHC & 52.11 & 29.60 & 12.39 & 4.17 & 0.03 & 0.66 & 0.15 \\
\hline $135-834 \mathrm{~B}-15 \mathrm{R}-2,56$ & 6 & PHC & 52.11 & 29.59 & 12.52 & 4.10 & 0.03 & 0.53 & 0.14 \\
\hline $135-834 \mathrm{~B}-30 \mathrm{R}-3,105$ & 7 & GRND & 51.68 & 29.74 & 12.67 & 4.00 & 0.06 & 0.77 & 0.53 \\
\hline $135-834 \mathrm{~B}-30 \mathrm{R}-3,105$ & 7 & PHC & 50.99 & 30.55 & 13.72 & 3.63 & 0.02 & 0.74 & 0.33 \\
\hline $135-834 \mathrm{~B}-30 \mathrm{R}-3,105$ & 7 & PHC & 52.08 & 29.23 & 12.52 & 4.03 & 0.03 & 0.84 & 1.04 \\
\hline $135-834 B-31 R-2,43$ & 7 & PHC & 48.78 & 32.56 & 15.25 & 2.69 & 0.02 & 0.44 & 0.16 \\
\hline $135-834 \mathrm{~B}-31 \mathrm{R}-2,43$ & 7 & PHR & 48.67 & 32.73 & 15.64 & 2.55 & 0.01 & 0.46 & 0.16 \\
\hline $135-834 \mathrm{~B}-31 \mathrm{R}-2,43$ & 7 & PHC & 49.82 & 31.55 & 14.28 & 3.09 & 0.03 & 0.47 & 0.19 \\
\hline $135-834 \mathrm{~B}-31 \mathrm{R}-2,43$ & 7 & PHR & 48.78 & 32.83 & 15.19 & 2.65 & 0.03 & 0.52 & 0.16 \\
\hline $135-834 \mathrm{~B}-31 \mathrm{R}-2,43$ & 7 & PHC & 51.64 & 30.39 & 12.89 & 3.95 & 0.04 & 0.57 & 0.07 \\
\hline $135-834 \mathrm{~B}-31 \mathrm{R}-2,43$ & 7 & PHR & 49.46 & 31.88 & 14.84 & 2.91 & 0.01 & 0.49 & 0.22 \\
\hline $135-834 \mathrm{~B}-35 \mathrm{R}-2,121$ & 8 & PHC & 49.44 & 32.09 & 14.37 & 2.74 & 0.02 & 0.51 & 0.19 \\
\hline $135-834 \mathrm{~B}-35 \mathrm{R}-2,121$ & 8 & PHR & 49.97 & 31.20 & 13.57 & 3.16 & 0.06 & 0.56 & 0.20 \\
\hline $135-834 \mathrm{~B}-35 \mathrm{R}-2,121$ & 8 & MIC & 50.89 & 30.68 & 13,46 & 3.54 & 0.02 & 0.69 & 0.22 \\
\hline $135-834 \mathrm{~B}-35 \mathrm{R}-2,121$ & 8 & GRND & 50.16 & 31.44 & 14.18 & 3.24 & 0.01 & 0.54 & 0.22 \\
\hline $135-834 \mathrm{~B}-35 \mathrm{R}-2,121$ & 8 & $\mathrm{CH}$ & 50.99 & 30.85 & 13.67 & 3.58 & 0.01 & 0.68 & 0.25 \\
\hline $135-834 \mathrm{~B}-35 \mathrm{R}-2,121$ & 8 & PHC & 46.99 & 33.85 & 16.18 & 1.76 & 0.01 & 0.40 & 0.16 \\
\hline $135-834 \mathrm{~B}-35 \mathrm{R}-2,121$ & 8 & PHR & 48.87 & 32.26 & 14.49 & 2.70 & 0.03 & 0.51 & 0.20 \\
\hline $135-834 \mathrm{~B}-36 \mathrm{R}-1$ & 8 & PHC & 49.93 & 32.00 & 14.46 & 2.77 & 0.01 & 0.60 & 0.23 \\
\hline $135-834 \mathrm{~B}-36 \mathrm{R}-1$ & 8 & PHR & 50.75 & 31.35 & 14.05 & 3.15 & 0.02 & 0.59 & 0.23 \\
\hline $135-834 \mathrm{~B}-36 \mathrm{R}-1,20$ & 8 & MIC & 56.85 & 26.33 & 9.26 & 6.15 & 0.09 & 1.04 & 0.07 \\
\hline $135-834 \mathrm{~B}-36 \mathrm{R}-1,20$ & 8 & MIC & 56.39 & 26.82 & 10.79 & 4.83 & 0.13 & 1.02 & 0.24 \\
\hline $135-834 \mathrm{~B}-36 \mathrm{R}-1,20$ & 8 & PHC & 49.35 & 31.61 & 14.96 & 2.82 & 0.03 & 0.55 & 0.21 \\
\hline $135-834 \mathrm{~B}-36 \mathrm{R}-1,20$ & 8 & PHC & 50.48 & 30.61 & 14.14 & 3.28 & 0.01 & 0.53 & 0.26 \\
\hline $135-834 \mathrm{~B}-36 \mathrm{R}-1,20$ & 8 & PHR & 50.38 & 30.88 & 14.58 & 3.16 & 0.01 & 0.52 & 0.26 \\
\hline $135-834 \mathrm{~B}-37 \mathrm{R}-1,46$ & $9 \mathrm{~B}$ & GRNDC & 52.04 & 29.39 & 12.37 & 4.22 & 0.03 & 0.55 & 0.19 \\
\hline $135-834 \mathrm{~B}-37 \mathrm{R}-1,46$ & $9 \mathrm{~B}$ & GRNDR & 55.66 & 26.29 & 8.88 & 6.12 & 0.06 & 0.92 & 0.09 \\
\hline $135-834 \mathrm{~B}-37 \mathrm{R}-1,46$ & $9 \mathrm{~B}$ & GRND & 52.28 & 28.90 & 12.14 & 4.40 & 0.03 & 0.85 & 0.25 \\
\hline $135-834 \mathrm{~B}-37 \mathrm{R}-1,46$ & $9 \mathrm{~B}$ & GRND & 53.68 & 28.42 & 10.79 & 5.15 & 0.03 & 0.84 & 0.13 \\
\hline $135-834 \mathrm{~B}-37 \mathrm{R}-1,46$ & $9 \mathrm{~B}$ & $\mathrm{PHC}$ & 49.40 & 31.25 & 14.14 & 3.12 & 0.02 & 0.43 & 0.19 \\
\hline $135-834 \mathrm{~B}-37 \mathrm{R}-1,46$ & $9 \mathrm{~B}$ & PHR & 52.85 & 29.68 & 11.83 & 4.59 & 0.02 & 0.80 & 0.17 \\
\hline $135-834 \mathrm{~B}-37 \mathrm{R}-1,46$ & $9 \mathrm{~B}$ & PHC & 47.37 & 33.15 & 16.16 & 2.18 & 0.00 & 0.41 & 0.17 \\
\hline
\end{tabular}


APPENDIX C (continued).

\begin{tabular}{|c|c|c|c|c|c|c|c|c|c|c|c|c|c|}
\hline $\begin{array}{l}\text { Core, section, } \\
\text { interval }(\mathrm{cm})\end{array}$ & Unit & Form & $\mathrm{SiO}_{2}$ & $\mathrm{Al}_{2} \mathrm{O}_{3}$ & $\mathrm{CaO}$ & $\mathrm{Na}_{2} \mathrm{O}$ & $\mathrm{K}_{2} \mathrm{O}$ & $\mathrm{FeO}^{*}$ & $\mathrm{MgO}$ & Total & AN & $\mathrm{AB}$ & OR \\
\hline $135-834 \mathrm{~B}-42 \mathrm{R}-1$ & $10 \mathrm{~A}$ & PHC & 52.17 & 31.00 & 12.87 & 3.75 & 0.05 & 0.00 & 0.15 & 99.99 & 65.3 & 34.4 & 0.3 \\
\hline $135-834 \mathrm{~B}-42 \mathrm{R}-1$ & $10 \mathrm{~A}$ & PHR & 51.83 & 31.20 & 13.12 & 3.52 & 0.07 & 0.00 & 0.17 & 99.91 & 67.0 & 32.6 & 0.4 \\
\hline $135-834 \mathrm{~B}-43 \mathrm{R}-1,107$ & $10 \mathrm{~A}$ & PHC & 51.16 & 30.51 & 12.45 & 3.98 & 0.02 & 0.67 & 0.09 & 98.88 & 63.0 & 36.6 & 0.1 \\
\hline 135-834B-43R-1, 107 & $10 \mathrm{~A}$ & PHR & 53.14 & 29.01 & 11.16 & 4.88 & 0.05 & 0.81 & 0.11 & 99.16 & 55.7 & 44.1 & 0.3 \\
\hline $135-834 \mathrm{~B}-43 \mathrm{R}-1,107$ & $10 \mathrm{~A}$ & PHC & 51.81 & 30.37 & 12.15 & 4.04 & 0.03 & 0.64 & 0.06 & 99.10 & 62.3 & 37.5 & 0.2 \\
\hline 135-834B-43R-1, 107 & $10 \mathrm{~A}$ & PHR & 51.42 & 30.33 & 12.21 & 4.04 & 0.04 & 0.65 & 0.08 & 98.77 & 62.4 & 37.4 & 0.3 \\
\hline 135-834B-43R-1, 107 & $10 \mathrm{~A}$ & MIC & 55.10 & 28.24 & 9.87 & 5.49 & 0.06 & 0.82 & 0.09 & 99.67 & 49.7 & 50.0 & 0.4 \\
\hline $135-834 \mathrm{~B}-46 \mathrm{R}-1,37$ & $10 \mathrm{~B}$ & PHC & 45.49 & 34.83 & 17.67 & 1.27 & 0.00 & 0.35 & 0.15 & 99.76 & 88.5 & 11.5 & 0.0 \\
\hline $135-834 \mathrm{~B}-46 \mathrm{R}-1,37$ & $10 \mathrm{~B}$ & PHR & 45.10 & 34.78 & 17.78 & 1.21 & 0.04 & 0.46 & 0.12 & 99.49 & 88.8 & 10.9 & 0.3 \\
\hline $135-834 \mathrm{~B}-46 \mathrm{R}-1,37$ & $10 \mathrm{~B}$ & PHC & 48.10 & 32.96 & 15.56 & 2.34 & 0.02 & 0.55 & 0.18 & 99.71 & 78.4 & 21.4 & 0.1 \\
\hline $135-834 \mathrm{~B}-46 \mathrm{R}-1,37$ & $10 \mathrm{~B}$ & PHR & 48.40 & 32.58 & 15.06 & 2.46 & 0.03 & 0.57 & 0.21 & 99.31 & 77.1 & 22.7 & 0.1 \\
\hline $135-834 \mathrm{~B}-46 \mathrm{R}-1,37$ & $10 \mathrm{~B}$ & MIC & 48.69 & 32.02 & 14.37 & 2.76 & 0.01 & 0.48 & 0.19 & 98.52 & 74.1 & 25.7 & 0.1 \\
\hline $135-834 \mathrm{~B}-46 \mathrm{R}-1,37$ & $10 \mathrm{~B}$ & GLOMC & 46.93 & 32.97 & 16.18 & 2.13 & 0.01 & 0.42 & 0.18 & 98.82 & 80.7 & 19.2 & 0.1 \\
\hline $135-834 \mathrm{~B}-47 \mathrm{R}-1,27$ & 11 & PHC & 54.50 & 29.29 & 11.25 & 4.74 & 0.04 & 0.95 & 0.12 & 100.89 & 56.6 & 43.2 & 0.2 \\
\hline 135-834B-47R-1, 27 & 11 & PHR & 56.78 & 28.87 & 10.13 & 4.97 & 0.07 & 0.88 & 0.09 & 101.79 & 52.8 & 46.8 & 0.4 \\
\hline $135-834 \mathrm{~B}-47 \mathrm{R}-1,130$ & 12 & PHC & 53.15 & 29.06 & 11.38 & 4.76 & 0.03 & 0.74 & 0.09 & 99.21 & 56.8 & 43.0 & 0.1 \\
\hline $135-834 \mathrm{~B}-47 \mathrm{R}-1,130$ & 12 & PHR & 53.57 & 28.82 & 11.01 & 5.01 & 0.01 & 0.77 & 0.08 & 99.27 & 54.8 & 45.0 & 0.1 \\
\hline $135-834 \mathrm{~B}-47 \mathrm{R}-1,130$ & 12 & MIC & 53.66 & 29.04 & 10.76 & 4.94 & 0.03 & 0.78 & 0.08 & 99.29 & 54.5 & 45.4 & 0.1 \\
\hline 135-834B-54R-1, 5 & 12 & PHC & 53.38 & 29.22 & 11.79 & 4.59 & 0.02 & 0.90 & 0.11 & 100.01 & 58.6 & 41.3 & 0.1 \\
\hline $135-834 \mathrm{~B}-54 \mathrm{R}-1,5$ & 12 & PHI & 53.64 & 28.27 & 11.24 & 4.85 & 0.05 & 1.11 & 0.12 & 99.28 & 56.0 & 43.7 & 0.3 \\
\hline $135-834 \mathrm{~B}-54 \mathrm{R}-1,5$ & 12 & PHR & 54.21 & 28.37 & 11.16 & 4.99 & 0.02 & 1.05 & 0.11 & 99.91 & 55.2 & 44.7 & 0.1 \\
\hline $135-834 \mathrm{~B}-56 \mathrm{R}-1,7$ & 12 & GRND & 54.06 & 28.36 & 11.09 & 5.01 & 0.04 & 0.98 & 0.10 & 99.64 & 54.9 & 44.8 & 0.3 \\
\hline $135-834 \mathrm{~B}-56 \mathrm{R}-1,7$ & 12 & PHC & 52.61 & 29.31 & 11.80 & 4.61 & 0.02 & 0.78 & 0.07 & 99.20 & 58.5 & 41.3 & 0.1 \\
\hline $135-834 \mathrm{~B}-56 \mathrm{R}-1,7$ & 12 & PHR & 54.63 & 28.80 & 11.08 & 5.02 & 0.04 & 0.81 & 0.08 & 100.46 & 54.8 & 44.9 & 0.3 \\
\hline $135-834 \mathrm{~B}-56 \mathrm{R}-1,7$ & 13 & PHC & 54.38 & 28.71 & 11.19 & 5.04 & 0.03 & 1.04 & 0.10 & 100.49 & 55.0 & 44.8 & 0.2 \\
\hline $135-835 \mathrm{~B}-3 \mathrm{R}-2,4$ & 1 & PHC & 47.15 & 33.42 & 16.18 & 1.80 & 0.02 & 0.49 & 0.14 & 99.20 & 83.1 & 16.8 & 0.1 \\
\hline $135-835 \mathrm{~B}-3 \mathrm{R}-2,4$ & $i$ & PHR & 49.11 & 31.54 & 14.77 & 2.68 & 0.03 & 0.62 & 0.19 & 98.94 & 75.1 & 24.7 & 0.2 \\
\hline $135-835 \mathrm{~B}-3 \mathrm{R}-2,4$ & 1 & MIC & 48.21 & 32.52 & 15.81 & 2.16 & 0.01 & 0.57 & 0.24 & 99.52 & 80.1 & 19.8 & 0.1 \\
\hline $135-835 \mathrm{~B}-3 \mathrm{R}-2,4$ & 1 & MIC & 49.38 & 31.36 & 14.59 & 2.67 & 0.05 & 0.69 & 0.25 & 98.99 & 74.9 & 24.8 & 0.3 \\
\hline $135-835 \mathrm{~B}-3 \mathrm{R}-1,137$ & I & PHC & 49.34 & 31.52 & 15.43 & 2.65 & 0.04 & 0.66 & 0.28 & 99.92 & 76.1 & 23.7 & 0.2 \\
\hline $135-835 \mathrm{~B}-3 \mathrm{R}-1,137$ & i & GLOMC & 49.14 & 31.44 & 15.36 & 2.59 & 0.03 & 0.62 & 0.23 & 99.41 & 76.5 & 23.3 & 0.2 \\
\hline $135-835 \mathrm{~B}-3 \mathrm{R}-1,137$ & i & GLOMR & 48.02 & 32.58 & 16.17 & 2.12 & 0.02 & 0.62 & 0.19 & 99.72 & 80.7 & 19.2 & 0.1 \\
\hline $135-835 \mathrm{~B}-3 \mathrm{R}-1,137$ & 1 & MIC & 48.55 & 32.21 & 15.94 & 2.20 & 0.03 & 0.71 & 0.22 & 99.86 & 79.8 & 20.0 & 0.2 \\
\hline $135-835 \mathrm{~B}-3 \mathrm{R}-1,137$ & 1 & MIC & 48.81 & 32.05 & 16.00 & 2.40 & 0.01 & 0.53 & 0.25 & 100.05 & 78.6 & 21.3 & 0.1 \\
\hline $135-835 \mathrm{~B}-3 \mathrm{R}-1,137$ & i & MICR & 48.25 & 32.24 & 16.12 & 2.21 & 0.04 & 0.66 & 0.23 & 99.75 & 80.0 & 19.8 & 0.2 \\
\hline $135-835 \mathrm{~B}-3 \mathrm{R}-1,137$ & $i$ & MIC & 51.68 & 29.44 & 13.26 & 3.70 & 0.09 & 1.11 & 0.35 & 99.63 & 66.1 & 33.4 & 0.6 \\
\hline $135-835 \mathrm{~B}-3 \mathrm{R}-2,4$ & $i$ & MIC & 48.21 & 32.52 & 15.81 & 2.16 & 0.01 & 0.57 & 0.24 & 99.52 & 80.1 & 19.8 & 0.1 \\
\hline $135-835 \mathrm{~B}-3 \mathrm{R}-2,4$ & 1 & MIC & 49.38 & 31.36 & 14.59 & 2.67 & 0.05 & 0.69 & 0.25 & 98.99 & 74.9 & 24.8 & 0.3 \\
\hline $135-835 \mathrm{~B}-3 \mathrm{R}-2,4$ & 1 & PHC & 47.15 & 33.42 & 16.18 & 1.80 & 0.02 & 0.49 & 0.14 & 99.20 & 83.1 & 16.8 & 0.1 \\
\hline $135-835 \mathrm{~B}-3 \mathrm{R}-2,4$ & 1 & PHR & 49.11 & 31.54 & 14.77 & 2.68 & 0.03 & 0.62 & 0.19 & 98.94 & 75.1 & 24.8 & 0.1 \\
\hline $135-836 \mathrm{~B}-3 \mathrm{R}-2,93$ & $4 \mathrm{~A}$ & GLOM & 53.11 & 29.04 & 11.40 & 4.79 & 0.02 & 0.69 & 0.10 & 99.15 & 56.7 & 43.1 & 0.2 \\
\hline $135-836 \mathrm{~B}-3 \mathrm{R}-2,93$ & $4 \mathrm{~A}$ & GLOM & 51.99 & 29.35 & 11.82 & 4.43 & 0.02 & 0.81 & 0.12 & 98.54 & 59.5 & 40.4 & 0.1 \\
\hline $135-836 \mathrm{~B}-3 \mathrm{R}-2,93$ & $4 \mathrm{~A}$ & PHC & 48.20 & 32.17 & 15.31 & 2.32 & 0.01 & 0.63 & 0.29 & 98.93 & 78.4 & 21.5 & 0.1 \\
\hline $135-836 \mathrm{~B}-3 \mathrm{R}-2,93$ & $4 \mathrm{~A}$ & PHI & 59.55 & 24.39 & 5.95 & 7.81 & 0.09 & 0.58 & 0.01 & 98.38 & 29.5 & 70.0 & 0.6 \\
\hline $135-836 \mathrm{~B}-3 \mathrm{R}-2,93$ & $4 \mathrm{~A}$ & PHR & 53.45 & 28.43 & 11.12 & 4.89 & 0.05 & 0.68 & 0.08 & 98.70 & 55.5 & 44.2 & 0.3 \\
\hline $135-836 \mathrm{~B}-5 \mathrm{R}-2,92$ & $4 \mathrm{~B}$ & PHC & 45.65 & 33.80 & 16.71 & 1.43 & 0.01 & 0.74 & 0.31 & 98.65 & 86.5 & 13.4 & 0.1 \\
\hline $135-836 \mathrm{~B}-5 \mathrm{R}-2,92$ & $4 \mathrm{~B}$ & PHR & 54.10 & 26.81 & 9.16 & 5.78 & 0.23 & 0.83 & 0.07 & 96.98 & 46.0 & 52.6 & 1.4 \\
\hline $135-836 \mathrm{~B}-5 \mathrm{R}-2,92$ & $4 \mathrm{~B}$ & PHC & 47.79 & 32.72 & 15.66 & 2.29 & 0.01 & 0.52 & 0.17 & 99.16 & 79.0 & 20.9 & 0.1 \\
\hline $135-836 \mathrm{~B}-5 \mathrm{R}-2,92$ & $4 \mathrm{~B}$ & PHR & 51.02 & 30.59 & 13.29 & 3.65 & 0.03 & 0.75 & 0.14 & 99.47 & 66.7 & 33.1 & 0.2 \\
\hline $135-836 \mathrm{~B}-7 \mathrm{R}-1,31$ & 5 & PHC & 47.11 & 33.10 & 16.55 & 1.82 & 0.03 & 0.65 & 0.17 & 99.43 & 83.3 & 16.6 & 0.2 \\
\hline $135-836 \mathrm{~B}-7 \mathrm{R}-1,31$ & 5 & PHR & 52,10 & 29.08 & 12.76 & 4.05 & 0.05 & 1.12 & 0.28 & 99.44 & 63.3 & 36.4 & 0.3 \\
\hline $135-836 \mathrm{~B}-7 \mathrm{R}-1,31$ & 5 & PHC & 49.37 & 31.25 & 14.65 & 2.72 & 0.03 & 0.70 & 0.18 & 98.90 & 74.8 & 25.1 & 0.2 \\
\hline $135-836 \mathrm{~B}-7 \mathrm{R}-1,31$ & 5 & PHC & 47.93 & 32.57 & 15.52 & 2.12 & 0.04 & 0.75 & 0.17 & 99.10 & 80.0 & 19.8 & 0.2 \\
\hline $135-836 \mathrm{~B}-7 \mathrm{R}-1,31$ & 5 & PHR & 50.42 & 30.94 & 14.13 & 3.20 & 0.04 & 0.86 & 0.24 & 99.83 & 70.7 & 29.0 & 0.3 \\
\hline $135-836 \mathrm{~B}-7 \mathrm{R}-1,31$ & 5 & MIC & 51.10 & 28.85 & 12.81 & 3.85 & 0.05 & 1.09 & 0.22 & 97.97 & 64.6 & 35.1 & 0.3 \\
\hline $135-836 \mathrm{~B}-9 \mathrm{M}-1,47$ & 5 & GRND & 53.89 & 27.90 & $\begin{array}{l}11.01 \\
11.52\end{array}$ & 4.79 & 0.07 & 1.10 & 0.12 & 99.39 & $\begin{array}{l}56.8 \\
56.8\end{array}$ & 42.8 & 0.4 \\
\hline $135-836 \mathrm{~B}-9 \mathrm{M}-1,47$ & 5 & PHC & 49.96 & 30.73 & 14.35 & 3.22 & 0.04 & 0.81 & 0.19 & 99.30 & 71.0 & 28.8 & 0.2 \\
\hline $135-836 \mathrm{~B}-9 \mathrm{M}-1,47$ & 5 & PHR & 52.35 & 29.65 & 12.94 & 3.91 & 0.05 & 1.02 & 0.16 & 100.08 & 64.4 & 35.3 & 0.3 \\
\hline $135-836 \mathrm{~B}-9 \mathrm{M}-1,47$ & 5 & $\mathrm{CH}$ & 50.54 & $\begin{array}{l}29.05 \\
31.09\end{array}$ & 14.57 & 3.04 & 0.03 & 0.85 & 0.20 & 100.32 & 72.4 & 27.4 & 0.2 \\
\hline $135-836 \mathrm{~B}-9 \mathrm{M}-1,47$ & 5 & MIC & 56.64 & 26.96 & 10.26 & 5.46 & 0.1 & 1.19 & 0.09 & 100.70 & 50.6 & 48.8 & 0.6 \\
\hline $135-836 \mathrm{~B}-9 \mathrm{M}-1,47$ & 5 & SKEL & 54.72 & 27.81 & 11.10 & 4.91 & 0.09 & 1.28 & 0.10 & 100.01 & 55.3 & 44.2 & 0.5 \\
\hline $135-836 \mathrm{~B}-9 \mathrm{M}-1,47$ & 5 & MIC & 57.51 & 27.50 & 10.53 & 4.72 & 0.15 & 1.15 & 0.08 & 101.64 & 54.7 & 44.4 & 0.9 \\
\hline $135-839 \mathrm{~B}-18 \mathrm{R}-1,54$ & 2 & PHC & 45.05 & 34.21 & 17.82 & 1.16 & 0.02 & 0.72 & 0.08 & 99.06 & 89.4 & 10.5 & 0.1 \\
\hline $135-839 \mathrm{~B}-18 \mathrm{R}-1,54$ & 2 & PHR & 44.71 & 34.51 & 17.89 & 1.03 & 0.02 & 0.73 & 0.07 & 98.96 & 90.4 & 9.4 & 0.2 \\
\hline $135-839 \mathrm{~B}-18 \mathrm{R}-1,54$ & 2 & PHC & 45.95 & $\begin{array}{l}33.51 \\
33.63\end{array}$ & $\begin{array}{l}17.89 \\
17.50\end{array}$ & 1.25 & 0.08 & 0.97 & 0.16 & 99.54 & 88.2 & 11.4 & 0.4 \\
\hline $135-839 \mathrm{~B}-18 \mathrm{R}-1,54$ & 2 & PHR & 44.31 & 33.91 & 17.84 & 1.14 & 0.03 & 0.71 & 0.11 & 98.05 & 89.4 & 10.4 & 0.2 \\
\hline $135-839 \mathrm{~B}-18 \mathrm{R}-1.54$ & 2 & PHC & 45.25 & 34.42 & 17.93 & 1.16 & 0.02 & 0.76 & 0.10 & 99.64 & 89.5 & 10.4 & 0.1 \\
\hline $135-839 \mathrm{~B}-18 \mathrm{R}-1,54$ & 2 & PHR & 49.03 & 31.41 & 15.21 & 2.68 & 0.06 & 0.96 & 0.18 & 99.53 & 75.6 & 24.1 & 0.3 \\
\hline $135-839 \mathrm{~B}-18 \mathrm{R}-1,54$ & 2 & MIC & 50.16 & 30.04 & 13.84 & 3.16 & 0.07 & 1.11 & 0.23 & 98.61 & 70.5 & 29.1 & 0.4 \\
\hline $135-839 \mathrm{~B}-18 \mathrm{R}-1,54$ & 2 & MIC & 49.42 & 29.33 & 13.45 & 2.72 & 0.13 & 2.09 & 0.53 & 97.67 & 72.6 & 26.6 & 0.8 \\
\hline $135-839 \mathrm{~B}-26 \mathrm{R}-1,23$ & 4 & MIC & 47.80 & 32.26 & 16.22 & 2.05 & 0.03 & 0.96 & 0.33 & 99.65 & 81.2 & 18.6 & 0.2 \\
\hline $135-839 \mathrm{~B}-26 \mathrm{R}-1,23$ & 4 & MIC & 47.47 & 32.68 & 16.32 & 2.02 & 0.03 & 0.75 & 0.22 & 99.49 & 81.5 & 18.3 & 0.2 \\
\hline $135-839 \mathrm{~B}-26 \mathrm{R}-1.23$ & 4 & MICR & 47.47 & 32.72 & 16.16 & 2.07 & 0.03 & 0.70 & 0.23 & 99.38 & 81.0 & 18.8 & 0.2 \\
\hline $135-839 \mathrm{~B}-27 \mathrm{R}-1,15$ & 5 & PHC & 45.66 & 34.24 & 17.86 & 1.24 & 0.03 & 0.71 & 0.11 & 99.85 & 88.6 & 11.2 & 0.2 \\
\hline $135-839 \mathrm{~B}-27 \mathrm{R}-1,15$ & 5 & PHI & 45.53 & 34.35 & 18.01 & 1.12 & 0.03 & 0.79 & 0.07 & 99.90 & $\begin{array}{l}89.7 \\
89.7\end{array}$ & 10.1 & 0.2 \\
\hline $135-839 \mathrm{~B}-27 \mathrm{R}-1,15$ & 5 & PHR & 47.71 & 32.81 & 16.20 & 2.07 & 0.05 & 0.81 & 0.15 & 99.80 & 81.0 & 18.7 & 0.3 \\
\hline $135-839 \mathrm{~B}-27 \mathrm{R}-1,15$ & 5 & PHC & 46.65 & 33.17 & 16.37 & 1.74 & 0.06 & 0.98 & 0.23 & 99.20 & 83.6 & 16.0 & 0.4 \\
\hline $135-839 \mathrm{~B}-27 \mathrm{R}-1,15$ & 5 & PHR & 50.21 & 30.80 & 13.85 & 3.05 & 0.07 & 1.04 & 0.20 & 99.22 & 71.2 & 28.3 & 0.5 \\
\hline $135-839 \mathrm{~B}-27 \mathrm{R}-1,15$ & 5 & GLOM & 44.60 & 34.52 & 17.60 & 1.15 & 0.03 & 0.69 & 0.07 & 98.66 & 89.2 & 10.6 & 0.2 \\
\hline $135-839 \mathrm{~B}-27 \mathrm{R}-1,15$ & 5 & MIC & 45.20 & 34.56 & 17.27 & 1.22 & 0.04 & 0.66 & 0.09 & 99.04 & $\begin{array}{l}8.2 \\
88.5\end{array}$ & 11.3 & 0.2 \\
\hline 135-839B-30R, 74 & 9 & MIC & 49.27 & 31.55 & 14.71 & 2.74 & 0.07 & 0.92 & 0.17 & 99.43 & 74.5 & 25.1 & 0.4 \\
\hline $135-839 \mathrm{~B}-30 \mathrm{R}, 74$ & 9 & MIC & 48.92 & 31.35 & 14.43 & $\begin{array}{l}2.94 \\
2.94\end{array}$ & 0.06 & $\begin{array}{l}0.92 \\
1.05\end{array}$ & 0.18 & 98.93 & 72.7 & 26.9 & 0.4 \\
\hline $135-839 \mathrm{~B}-30 \mathrm{R}, 74$ & 9 & PHC & 49.85 & 31.11 & 14.48 & 2.92 & 0.07 & 1.04 & 0.19 & 99.66 & 72.9 & 26.7 & 0.4 \\
\hline
\end{tabular}

Notes: $\mathrm{C}=$ core, $\mathrm{R}=$ rim, $\mathrm{I}=$ interior, $\mathrm{PH}=$ phenocryst, $\mathrm{MIC}=$ microphenocryst, $\mathrm{SKEL}=$ skeletal, $\mathrm{GRND}=$ groundmass, $\mathrm{OPHI}=$ ophitic, $\mathrm{CH}=$ chadacryst, and GLOM $=$ glomerocryst. 
APPENDIX D

Microprobe Analyses of Clinopyroxene, Sites 834 through 839

\begin{tabular}{|c|c|c|c|c|c|c|c|c|c|c|c|c|c|c|}
\hline $\begin{array}{l}\text { Core, section, } \\
\text { interval }(\mathrm{cm})\end{array}$ & Unit & Form & $\mathrm{SiO}_{2}$ & $\mathrm{TiO}_{2}$ & $\mathrm{Al}_{2} \mathrm{O}_{3}$ & $\mathrm{FeO}^{*}$ & $\mathrm{MnO}$ & $\mathrm{MgO}$ & $\mathrm{CaO}$ & $\mathrm{Na}_{2} \mathrm{O}$ & $\mathrm{NiO}$ & $\mathrm{Cr}_{2} \mathrm{O}_{3}$ & Sum & wo \\
\hline $135-834 \mathrm{~A}-13 \mathrm{X}-2,24$ & $2 \mathrm{~A}$ & PHC & 52.77 & 0.40 & 2.62 & 4.38 & 0.14 & 17.53 & 21.87 & 0.20 & 0.02 & 0.44 & 100.37 & 43.9 \\
\hline 135-834A-13X-2, 24 & $2 \mathrm{~A}$ & PHR & 52.28 & 0.60 & 3.13 & 5.53 & 0.17 & 17.35 & 20.94 & 0.17 & 0.05 & 0.28 & 100.50 & 42.3 \\
\hline $135-834 \mathrm{~A}-13 \mathrm{X}-2,24$ & $2 \mathrm{~A}$ & PHC & 53.10 & 0.41 & 2.31 & 4.49 & 0.12 & 17.95 & 21.12 & 0.16 & 0.04 & 0.41 & 100.11 & 42.5 \\
\hline $135-834 \mathrm{~A}-13 \mathrm{X}-2,24$ & $2 \mathrm{~A}$ & PHR & 51.65 & 0.49 & 3.57 & 4.24 & 0.12 & 16.62 & 22.20 & 0.21 & 0.04 & 0.66 & 99.80 & 45.6 \\
\hline $135-834 \mathrm{~A}-13 \mathrm{X}-2,24$ & $2 \mathrm{~A}$ & MIC & 48.40 & 1.91 & 5.95 & 9.71 & 0.25 & 13.73 & 19.56 & 0.39 & 0.00 & 0.03 & 99.93 & 42.1 \\
\hline 135-834A-13X-2, 24 & $2 \mathrm{~A}$ & MIC & 49.55 & 1.48 & 5.14 & 9.58 & 0.24 & 14.84 & 19.10 & 0.29 & 0.06 & 0.00 & 100.28 & 40.3 \\
\hline $135-834 \mathrm{~A}-14 \mathrm{X}-1,6$ & $2 \mathrm{~A}$ & MIC & 52.32 & 0.67 & 2.49 & 7.87 & 0.27 & 17.45 & 18.86 & 0.16 & 0.02 & 0.04 & 100.15 & 38.1 \\
\hline $135-834 \mathrm{~A}-14 \mathrm{X}-1,6$ & $2 \mathrm{~A}$ & MIC & 50.37 & 0.96 & 4.30 & 6.25 & 0.11 & 15.46 & 20.92 & 0.26 & 0.04 & 0.09 & 98.76 & 44.1 \\
\hline $135-834 \mathrm{~A}-14 \mathrm{X}-1,6$ & $2 \mathrm{~A}$ & MIC & 49.93 & 0.87 & 4.51 & 6.29 & 0.13 & 15.97 & 21.16 & 0.27 & 0.05 & 0.15 & 99.33 & 43.7 \\
\hline $135-834 \mathrm{~A}-14 \mathrm{X}-1,6$ & $2 \mathrm{~A}$ & MIC & 51.06 & 0.81 & 2.95 & 8.06 & 0.27 & 16.55 & 19.38 & 0.18 & 0.05 & 0.03 & 99.34 & 39.6 \\
\hline $135-834 \mathrm{~A}-14 \mathrm{X}-1,6$ & $2 \mathrm{~A}$ & GLOM & 47.94 & 1.48 & 3.79 & 13.75 & 0.37 & 11.74 & 18.52 & 0.42 & 0.04 & 0.00 & 98.05 & 40.4 \\
\hline $135-834 \mathrm{~B}-8 \mathrm{R}-1,110$ & $2 \mathrm{~A}$ & PHC & 53.29 & 0.41 & 1.96 & 5.33 & 0.20 & 16.67 & 21.34 & 0.19 & 0.03 & 0.09 & 99.51 & 43.7 \\
\hline $135-834 \mathrm{~B}-8 \mathrm{R}-1,110$ & $2 \mathrm{~A}$ & PHC & 51.93 & 0.82 & 1.82 & 10.98 & 0.31 & 15.01 & 18.41 & 0.26 & 0.01 & 0.02 & 99.57 & 38.3 \\
\hline $135-834 \mathrm{~B}-8 \mathrm{R}-1,110$ & $2 \mathrm{~A}$ & PHC & 49.82 & 1.20 & 3.94 & 10.36 & 0.34 & 13.58 & 19.63 & 0.36 & 0.01 & 0.03 & 99.27 & 41.9 \\
\hline $135-834 \mathrm{~B}-8 \mathrm{R}-1,110$ & $2 \mathrm{~A}$ & PHR & 48.74 & 1.68 & 3.63 & 13.36 & 0.31 & 11.85 & 19.05 & 0.46 & 0.02 & 0.00 & 99.10 & 41.2 \\
\hline $135-834 \mathrm{~B}-8 \mathrm{R}-1,110$ & $2 \mathrm{~A}$ & PHC & 50.66 & 0.92 & 3.83 & 7.88 & 0.17 & 14.80 & 20.58 & 0.30 & 0.00 & 0.04 & 99.18 & 43.4 \\
\hline $135-834 \mathrm{~A}-15 \mathrm{X}-1,28$ & $2 \mathrm{~B}$ & PHC & 52.77 & 0.51 & 2.52 & 6.09 & 0.20 & 19.10 & 19.22 & 0.19 & 0.06 & 0.18 & 100.84 & 37.9 \\
\hline $135-834 \mathrm{~A}-15 \mathrm{X}-1,28$ & $2 \mathrm{~B}$ & MIC & 51.91 & 0.62 & 1.77 & 8.11 & 0.25 & 17.56 & 18.97 & 0.18 & 0.03 & 0.03 & 99.43 & 38.0 \\
\hline $135-834 \mathrm{~A}-15 \mathrm{X}-1,28$ & $2 \mathrm{~B}$ & MIC & 50.02 & 1.05 & 4.31 & 7.72 & 0.22 & 15.33 & 20.62 & 0.28 & 0.00 & 0.04 & 99.59 & 42.8 \\
\hline $135-834 \mathrm{~A}-17 \mathrm{X}-4,92$ & 5 & MIC & 51.89 & 0.86 & 1.53 & 12.34 & 0.44 & 14.02 & 18.35 & 0.30 & 0.00 & 0.05 & 99.78 & 38.4 \\
\hline $135-834 \mathrm{~A}-17 \mathrm{X}-4,92$ & 5 & OPHC & 51.43 & 0.84 & 3.09 & 7.93 & 0.20 & 15.09 & 20.56 & 0.28 & 0.01 & 0.02 & 99.45 & 42.9 \\
\hline $135-834 \mathrm{~A}-17 \mathrm{X}-4,92$ & 5 & OPHI & 50.87 & 1.03 & 3.71 & 7.75 & 0.20 & 14.68 & 20.56 & 0.29 & 0.00 & 0.07 & 99.16 & 43.6 \\
\hline $135-834 \mathrm{~A}-17 \mathrm{X}-4,92$ & 5 & OPHR & 52.02 & 0.84 & 1.35 & 12.76 & 0.44 & 13.91 & 18.35 & 0.30 & 0.03 & 0.03 & 100.03 & 38.2 \\
\hline $135-834 \mathrm{~B}-10 \mathrm{R}-1,37$ & 5 & OPHC & 50.84 & 0.73 & 1.72 & 5.36 & 0.16 & 16.33 & 21.81 & 0.22 & 0.05 & 0.05 & 97.27 & 45.8 \\
\hline 135-834B-10R-1, 37 & 5 & OPHI & 51.27 & 0.87 & 4.20 & 6.59 & 0.12 & 16.12 & 21.88 & 0.24 & 0.05 & 0.05 & 101.39 & 45.4 \\
\hline 135-834B-10R-1, 37 & 5 & OPHR & 50.04 & 1.51 & 3.14 & 12.41 & 0.40 & 13.19 & 19.01 & 0.31 & 0.03 & 0.03 & 100.07 & 40.8 \\
\hline 135-834B-10R-1, 37 & 5 & OPHC & 50.29 & 0.88 & 4.62 & 5.48 & 0.13 & 16.02 & 21.55 & 0.28 & 0.01 & 0.01 & 99.27 & 45.4 \\
\hline 135-834B-10R-1, 37 & 5 & OPHI & 50.52 & 1.18 & 4.02 & 9.11 & 0.24 & 15.02 & 20.27 & 0.35 & 0.02 & 0.02 & 100.75 & 42.5 \\
\hline $135-834 \mathrm{~B}-10 \mathrm{R}-1,37$ & 5 & OPHR & 49.05 & 1.61 & 3.76 & 12.16 & 0.27 & 13.48 & 19.13 & 0.44 & 0.02 & 0.02 & 99.94 & 40.9 \\
\hline $135-834 \mathrm{~B}-14 \mathrm{R}-1,32$ & 6 & PHC & 51.61 & 0.64 & 1.91 & 7.24 & 0.21 & 17.10 & 19.77 & 0.28 & 0.03 & 0.24 & 99.03 & 40.0 \\
\hline $135-834 \mathrm{~B}-14 \mathrm{R}-1,32$ & 6 & PHR & 51.37 & 0.74 & 2.41 & 6.74 & 0.18 & 16.44 & 20.79 & 0.26 & 0.02 & 0.21 & 99.16 & 42.4 \\
\hline 135-834B-14R-1, 32 & 6 & PHC & 49.77 & 1.39 & 3.86 & 8.42 & 0.23 & 14.67 & 20.09 & 0.35 & 0.04 & 0.19 & 99.01 & 42.5 \\
\hline $135-834 \mathrm{~B}-14 \mathrm{R}-1,32$ & 6 & PHR & 49.23 & 1.58 & 3.68 & 9.37 & 0.29 & 14.43 & 20.32 & 0.43 & 0.01 & 0.05 & 99.39 & 42.4 \\
\hline $135-834 \mathrm{~B}-14 \mathrm{R}-1,32$ & 6 & PHC & 49.88 & 1.18 & 4.23 & 7.60 & 0.21 & 14.93 & 20.17 & 0.37 & 0.03 & 0.18 & 98.78 & 42.9 \\
\hline $135-834 \mathrm{~B}-14 \mathrm{R}-1,32$ & 6 & PHR & 50.49 & 0.89 & 3.47 & 6.37 & 0.22 & 15.91 & 20.84 & 0.29 & 0.04 & 0.45 & 98.97 & 43.3 \\
\hline 135-834B-14R-1, 32 & 6 & MIC & 49.86 & 1.27 & 3.94 & 8.75 & 0.23 & 15.06 & 19.52 & 0.36 & 0.00 & 0.09 & 99.08 & 41.1 \\
\hline 135-834B-15R-1, 43 & 6 & PHC & 50.04 & 1.21 & 4.54 & 7.78 & 0.27 & 15.30 & 19.55 & 0.34 & 0.06 & 0.20 & 99.29 & 41.5 \\
\hline $135-834 \mathrm{~B}-15 \mathrm{R}-1,43$ & 6 & PHR & 50.98 & 1.17 & 3.90 & 7.66 & 0.20 & 15.18 & 19.94 & 0.29 & 0.00 & 0.06 & 99.38 & 42.3 \\
\hline $135-834 \mathrm{~B}-15 \mathrm{R}-1,43$ & 6 & GLOM & 50.53 & 1.01 & 4.31 & 6.54 & 0.21 & 15.86 & 19.92 & 0.32 & 0.05 & 0.47 & 99.22 & 42.2 \\
\hline $135-834 \mathrm{~B}-15 \mathrm{R}-1,43$ & 6 & GLOM & 50.97 & 0.91 & 4.07 & 6.21 & 0.19 & 15.49 & 20.88 & 0.29 & 0.05 & 0.37 & 99.43 & 44.0 \\
\hline 135-834B-15R-2, 35 & 6 & GLOM & 51.04 & 0.97 & 4.65 & 7.22 & 0.16 & 16.38 & 20.55 & 0.32 & 0.00 & 0.38 & 101.67 & 43.5 \\
\hline 135-834B-15R-2, 35 & 6 & GLOM & 50.44 & 1.42 & 4.53 & 7.93 & 0.15 & 15.46 & 20.91 & 0.30 & 0.03 & 0.17 & 101.34 & 44.6 \\
\hline 135-834B-15R-2, 35 & 6 & PHC & 50.35 & 1.43 & 3.88 & 10.40 & 0.25 & 15.75 & 18.35 & 0.39 & 0.04 & 0.15 & 100.99 & 39.8 \\
\hline 135-834B-15R-2, 35 & 6 & PHR & 50.86 & 1.11 & 4.29 & 8.31 & 0.21 & 15.81 & 19.50 & 0.33 & 0.01 & 0.24 & 100.67 & 42.2 \\
\hline $135-834 \mathrm{~B}-15 \mathrm{R}-2,35$ & 6 & PHC & 51.02 & 0.97 & 4.15 & 7.42 & 0.15 & 16.17 & 20.89 & 0.32 & 0.03 & 0.41 & 101.53 & 43.6 \\
\hline $135-834 \mathrm{~B}-15 \mathrm{R}-2,35$ & 6 & PHR & 51.17 & 1.03 & 3.34 & 8.33 & 0.23 & 16.27 & 20.41 & 0.29 & 0.00 & 0.08 & 101.15 & 42.3 \\
\hline 135-834B-30R-3, 105 & 7 & GRND & 48.09 & 1.03 & 6.25 & 8.61 & 0.16 & 11.96 & 21.80 & 0.42 & 0.04 & 0.17 & 98.53 & 48.1 \\
\hline 135-834B-30R-3, 105 & 7 & GRND & 47.82 & 2.32 & 5.05 & 10.63 & 0.29 & 11.69 & 20.51 & 0.51 & 0.04 & 0.27 & 99.13 & 45.3 \\
\hline 135-834B-30R-3, 105 & 7 & MIC & 49.87 & 1.26 & 3.18 & 11.07 & 0.28 & 13.11 & 19.59 & 0.40 & 0.00 & 0.05 & 99.81 & 42.0 \\
\hline 135-834B-30R-3, 105 & 7 & MIC & 48.42 & 1.72 & 5.18 & 9.25 & 0.23 & 12.68 & 20.56 & 0.41 & 0.01 & 0.21 & 98.67 & 45.1 \\
\hline 135-834B-35R-2, 121 & 8 & PHC & 50.78 & 0.61 & 4.48 & 5.13 & 0.17 & 16.92 & 19.49 & 0.19 & 0.00 & 0.69 & 98.46 & 41.3 \\
\hline 135-834B-35R-2, 121 & 8 & PHR & 50.94 & 0.59 & 3.83 & 5.08 & 0.11 & 17.06 & 20.15 & 0.23 & 0.04 & 0.65 & 98.68 & 42.0 \\
\hline 135-834B-35R-2, 121 & 8 & PHC & 52.95 & 0.35 & 2.46 & 5.19 & 0.16 & 17.78 & 19.50 & 0.19 & 0.02 & 0.40 & 99.00 & 40.3 \\
\hline $135-834 \mathrm{~B}-35 \mathrm{R}-2,121$ & 8 & PHC & 52.68 & 0.35 & 2.28 & 4.79 & 0.17 & 18.11 & 19.78 & 0.18 & 0.04 & 0.50 & 98.88 & 40.5 \\
\hline 135-834B-35R-2, 121 & 8 & GRND & 50.91 & 0.67 & 4.18 & 5.97 & 0.14 & 16.80 & 19.41 & 0.22 & 0.02 & 0.22 & 98.54 & 40.8 \\
\hline 135-834B-35R-2, 121 & 8 & GRND & 49.81 & 1.02 & 5.21 & 7.01 & 0.21 & 16.52 & 18.43 & 0.21 & 0.01 & 0.05 & 98.48 & 39.2 \\
\hline 135-834B-35R-2, 121 & 8 & MIC & 52.35 & 0.45 & 2.51 & 6.09 & 0.19 & 18.38 & 17.92 & 0.13 & 0.04 & 0.29 & 98.35 & 37.0 \\
\hline $135-834 \mathrm{~B}-36 \mathrm{R}-1,20$ & 8 & PHC & 51.92 & 0.40 & 2.30 & 4.86 & 0.16 & 17.38 & 20.50 & 0.15 & 0.03 & 0.43 & 98.13 & 42.2 \\
\hline $135-834 \mathrm{~B}-36 \mathrm{R}-1,20$ & 8 & PHR & 49.52 & 1.29 & 5.79 & 6.70 & 0.19 & 15.21 & 20.38 & 0.26 & 0.00 & 0.02 & 99.36 & 43.4 \\
\hline $135-834 \mathrm{~B}-36 \mathrm{R}-1,20$ & 8 & PHC & 52.76 & 0.40 & 2.14 & 5.95 & 0.21 & 19.12 & 18.12 & 0.11 & 0.00 & 0.25 & 99.06 & 36.6 \\
\hline $135-834 \mathrm{~B}-36 \mathrm{R}-1,20$ & 8 & PHR & 49.95 & 1.13 & 4.96 & 7.48 & 0.23 & 15.79 & 19.40 & 0.22 & 0.06 & 0.04 & 99.26 & 40.9 \\
\hline $135-834 \mathrm{~B}-36 \mathrm{R}-1,20$ & 8 & PHC & 50.98 & 0.71 & 4.51 & 4.98 & 0.12 & 16.51 & 20.58 & 0.21 & 0.04 & 0.4 & 99.05 & 43.3 \\
\hline 135-834B-36R-1, 20 & 8 & PHR & 51.12 & 0.79 & 3.86 & 5.85 & 0.19 & 16.68 & 19.89 & 0.23 & 0.01 & 0.28 & 98.90 & 41.6 \\
\hline 135-834B-36R-1, 20 & 8 & MIC & 51.22 & 0.58 & 3.37 & 6.00 & 0.20 & 17.29 & 19.63 & 0.18 & 0.03 & 0.25 & 98.75 & 40.5 \\
\hline 135-834B-36R-1, 20 & 8 & MIC & 50.21 & 0.75 & 4.01 & 6.35 & 0.15 & 16.28 & 19.98 & 0.23 & 0.05 & 0.28 & 98.29 & 41.9 \\
\hline $135-834 \mathrm{~B}-36 \mathrm{R}-1,20$ & 8 & MICR & 50.23 & 0.91 & 4.70 & 7.96 & 0.17 & 16.04 & 19.01 & 0.27 & 0.04 & 0.01 & 99.34 & 39.9 \\
\hline $135-834 \mathrm{~B}-37 \mathrm{R}-1,46$ & 9 & GRND & 49.27 & 1.24 & 4.5 & 7.96 & 0.17 & 15.01 & 19.84 & 0.32 & 0.00 & 0.0 & 98.4 & 42.2 \\
\hline $135-834 \mathrm{~B}-37 \mathrm{R}-1,46$ & 9 & GRND & 48.9 & 1.4 & 4.41 & 9.4 & 0.31 & 15.36 & 17.58 & 0.32 & 0.02 & 0.08 & 97.99 & 37.7 \\
\hline 135-834B-43R-1, 107 & 10 & GRND & 51.28 & 1.09 & 3.08 & 11.18 & 0.31 & 14.81 & 18.24 & 0.35 & 0.00 & 0.00 & 100.34 & 38.3 \\
\hline 135-834B-43R-1, 107 & 10 & GRND & 49.14 & 1.85 & 3.28 & 14.43 & 0.40 & 11.74 & 18.45 & 0.45 & 0.00 & 0.02 & 99.76 & 40.0 \\
\hline 135-834B-43R-1, 107 & 10 & GLOM & 48.47 & 1.91 & 5.95 & 11.01 & 0.23 & 14.37 & 18.31 & 0.3 & 0.02 & 0.09 & 100.74 & 38.5 \\
\hline $135-834 \mathrm{~B}-43 \mathrm{R}-1,107$ & 10 & MIC & 52.68 & 0.6 & 2.11 & 11. & 0.3 & 17.31 & 14.95 & 0.2 & 0.03 & 0.05 & 99 & 30.9 \\
\hline 135-834B-46R-1, 37 & 11 & PHC & 51.00 & 0.79 & 4.51 & 5.69 & 0.19 & 16.79 & 20.54 & 0.28 & 0.00 & 0.16 & 99.95 & 42.0 \\
\hline 135-834B-46R-1, 37 & 11 & PHR & 51.14 & 0.57 & 4.34 & 4.74 & 0.07 & 16.17 & 21.47 & 0.23 & 0.02 & 0.75 & 99.5 & 44.9 \\
\hline $135-834 \mathrm{~B}-47 \mathrm{R}-1,27$ & 12 & PHC & 50.37 & 1.1 & 3.0 & 11.40 & 0. & 13.56 & 19.20 & 0.3 & 0.01 & 0.00 & 99.51 & 40.7 \\
\hline $135-834 \mathrm{~B}-47 \mathrm{R}-1,27$ & 12 & $\mathrm{PH}$ & 48.74 & 1.5 & 4.3 & 12.01 & 0. & 13.50 & 18.28 & 0.37 & 0.00 & 0.0 & 99.16 & 39.1 \\
\hline 135-834B-47R-1, 27 & 12 & PHC & 48.56 & 1.67 & 4.19 & 11.71 & 0.32 & 13.38 & 19.00 & 0.38 & 0.03 & 0.05 & 99.29 & 40.4 \\
\hline 135-834B-47R-1, 27 & 12 & PHC & 50.25 & 1.37 & 3.74 & 10.75 & 0.32 & 13.33 & 19.81 & 0.31 & 0.01 & 0.0 & 99.89 & 42.2 \\
\hline 135-834B-47R-1, 27 & 12 & PHR & 49.54 & 1.1 & 3.7 & 9.90 & 0.2 & 13.42 & 20.40 & 0.3 & 0.01 & 0.0 & 98.81 & 43.4 \\
\hline $135-834 \mathrm{R}-47 \mathrm{P}-13$ & 12 & PH & 49.3 & 1.3 & 4. & 10.2 & 0.2 & 13. & 19.67 & 0.37 & 0. & 0.00 & 98.96 & 41.7 \\
\hline $4 \mathrm{~B}-47 \mathrm{R}-1,130$ & 12 & PHR & 50.37 & 1.25 & 3.77 & 10.64 & 0.37 & 14.33 & 19.17 & 0.37 & 0.02 & 0.06 & 100.35 & 40.0 \\
\hline $135-834 \mathrm{~B}-47 \mathrm{R}-1,130$ & 12 & PHC & 48.10 & 1.83 & 5.23 & 11.56 & 0.35 & 13.25 & 19.12 & 0.41 & 0.01 & 0.02 & 99.88 & 40.6 \\
\hline $135-834 \mathrm{~B}-47 \mathrm{R}-1,130$ & 12 & PHR & 50.52 & 1.13 & 3.69 & 10.38 & 0.33 & 14.24 & 19.97 & 0.39 & 0.00 & 0.03 & 100.68 & 41.3 \\
\hline
\end{tabular}


APPENDIX D (continued).

\begin{tabular}{|c|c|c|c|c|c|c|c|c|c|c|c|c|c|c|c|c|}
\hline $\begin{array}{l}\text { Core, section, } \\
\text { interval }(\mathrm{cm})\end{array}$ & Unit & Form & $\mathrm{SiO}_{2}$ & $\mathrm{TiO}_{2}$ & $\mathrm{Al}_{2} \mathrm{O}_{3}$ & $\mathrm{FeO}^{\circ}$ & $\mathrm{MnO}$ & $\mathrm{MgO}$ & $\mathrm{CaO}$ & $\mathrm{Na}_{2} \mathrm{O}$ & $\mathrm{NiO}$ & $\mathrm{Cr}_{2} \mathrm{O}_{3}$ & Sum & wo & $\mathrm{EN}$ & FS \\
\hline 135-835B-3R-1, 137 & 1 & PHC & 52.03 & 0.38 & 4.02 & 5.70 & 0.22 & 17.23 & 20.45 & 0.22 & 0.05 & 0.88 & 101.18 & 37.3 & 51.8 & 11.0 \\
\hline $135-835 \mathrm{~B}-3 \mathrm{R}-1,137$ & 1 & PHR & 53.43 & 0.35 & 1.95 & 7.44 & 0.27 & 18.61 & 18.23 & 0.14 & 0.05 & 0.11 & 100.58 & 42.4 & 47.7 & 9.9 \\
\hline 135-835B-3R-1, 137 & 1 & $\mathrm{PHC}$ & 52.16 & 0.44 & 3.88 & 6.66 & 0.18 & 16.90 & 20.46 & 0.19 & 0.02 & 0.26 & 101.15 & 41.4 & 48.0 & 10.6 \\
\hline $135-835 \mathrm{~B}-3 \mathrm{R}-1,137$ & 1 & PHR & 51.97 & 0.49 & 4.50 & 7.04 & 0.16 & 16.62 & 19.46 & 0.18 & 0.02 & 0.18 & 100.62 & 40.0 & 48.4 & 11.5 \\
\hline 135-835B-3R-1, 137 & 1 & PHC & 50.96 & 0.50 & 4.86 & 5.81 & 0.15 & 16.53 & 19.62 & 0.20 & 0.07 & 0.45 & 99.15 & 41.5 & 48.6 & 9.9 \\
\hline $135-835 \mathrm{~B}-3 \mathrm{R}-1,137$ & i & $\mathrm{PHC}$ & 50.49 & 0.74 & 4.61 & 6.94 & 0.19 & 16.46 & 19.65 & 0.19 & 0.03 & 0.29 & 99.59 & 40.8 & 47.6 & 11.6 \\
\hline $135-835 \mathrm{~B}-3 \mathrm{R}-1,137$ & $\mathrm{i}$ & PHR & 51.47 & 0.56 & 3.43 & 6.07 & 0.17 & 16.09 & 21.07 & 0.16 & 0.02 & 0.23 & 99.27 & 43.6 & 46.3 & 10.1 \\
\hline $135-835 \mathrm{~B}-3 \mathrm{R}-1,137$ & 1 & GLOMC & 52.51 & 0.38 & 2.35 & 6.13 & 0.20 & 17.70 & 19.78 & 0.16 & 0.01 & 0.26 & 99.48 & 40.1 & 49.9 & 10.0 \\
\hline 135-835B-3R-1, 137 & 1 & GLOMR & 51.78 & 0.52 & 3.15 & 7.12 & 0.18 & 16.64 & 19.80 & 0.17 & 0.04 & 0.05 & 99.45 & 40.7 & 47.6 & 11.7 \\
\hline $135-835 \mathrm{~B}-3 \mathrm{R}-1,137$ & 1 & GLOMC & 51.57 & 0.47 & 3.26 & 5.63 & 0.18 & 16.65 & 20.59 & 0.17 & 0.04 & 0.33 & 98.89 & 42.7 & 48.0 & 9.4 \\
\hline $135-835 \mathrm{~B}-3 \mathrm{R}-2,4$ & $i$ & MIC & 52.95 & 0.31 & 1.94 & 6.16 & 0.21 & 17.71 & 19.41 & 0.16 & 0.00 & 0.12 & 98.97 & 39.6 & 50.3 & 10.2 \\
\hline $135-835$ B-3R- 2,4 & 1 & MIC & 52.53 & 0.35 & 2.68 & 6.54 & 0.25 & 18.16 & 17.60 & 0.18 & 0.00 & 0.09 & 98.38 & 36.5 & 52.5 & 11.0 \\
\hline $135-836 \mathrm{~B}-3 \mathrm{R}-2,93$ & $4 \mathrm{~A}$ & GLOM & 51.96 & 0.55 & 1.84 & 9.29 & 0.25 & 15.59 & 19.26 & 0.19 & 0.06 & 0.04 & 99.03 & 39.8 & 44.8 & 15.4 \\
\hline $135-836 \mathrm{~B}-3 \mathrm{R}-2,93$ & $4 \mathrm{~A}$ & PHC & 52.51 & 0.40 & 1.73 & 7.49 & 0.22 & 16.47 & 19.81 & 0.17 & 0.04 & 0.00 & 98.84 & 40.7 & 47.0 & 12.4 \\
\hline $135-836 \mathrm{~B}-3 \mathrm{R}-2,93$ & $4 \mathrm{~A}$ & $\mathrm{PHC}$ & 52.85 & 0.31 & 1.84 & 5.45 & 0.19 & 17.34 & 20.42 & 0.14 & 0.00 & 0.03 & 98.57 & 41.7 & 49.3 & 9.0 \\
\hline $135-836 \mathrm{~B}-5 \mathrm{R}-2,92$ & $4 \mathrm{~B}$ & PHC & 53.03 & 0.28 & 2.05 & 4.88 & 0.15 & 18.08 & 21.08 & 0.16 & 0.04 & 0.27 & 100.02 & 43.1 & 49.9 & 7.0 \\
\hline $135-836 \mathrm{~B}-5 \mathrm{R}-2,92$ & $4 \mathrm{~B}$ & PHR & 51.65 & 0.59 & 3.17 & 8.38 & 0.25 & $\begin{array}{l}10.00 \\
15.89\end{array}$ & 20.10 & 0.25 & 0.03 & 0.02 & 100.33 & 42.4 & 45.3 & 12.4 \\
\hline $135-836 \mathrm{~B}-5 \mathrm{R}-2,92$ & $4 \mathrm{~B}$ & $\mathrm{PHC}$ & 51.39 & 0.68 & 3.14 & 9.47 & 0.26 & 15.48 & 20.58 & 0.26 & 0.06 & 0.00 & 101.32 & 42.8 & 43.5 & 13.8 \\
\hline $135-836 \mathrm{~B}-5 \mathrm{R}-2,92$ & $4 B$ & PHR & 50.97 & 0.76 & 1.25 & 20.57 & 0.65 & 12.02 & 15.85 & 0.25 & 0.01 & 0.03 & 102.36 & 34.1 & 34.9 & 31.0 \\
\hline $135-836 \mathrm{~B}-5 \mathrm{R}-2,92$ & $4 \mathrm{~B}$ & PHC & 52.62 & 0.40 & 3.42 & 5.26 & 0.15 & 16.99 & 21.87 & 0.17 & 0.06 & 0.25 & 101.19 & 45.1 & 47.3 & 7.6 \\
\hline $135-836 \mathrm{~B}-5 \mathrm{R}-2,92$ & $4 \mathrm{~B}$ & GLOM & 53.57 & 0.31 & 2.20 & 5.39 & 0.12 & 17.87 & 21.21 & 0.15 & 0.02 & 0.12 & 100.96 & 43.2 & 49.2 & 7.6 \\
\hline $135-836 \mathrm{~B}-7 \mathrm{R}-1,31$ & 5 & MIC & 51.57 & 0.57 & 3.20 & 8.07 & 0.16 & 16.13 & 19.85 & 0.18 & 0.02 & 0.07 & 99.82 & 40.7 & 46.0 & 13.4 \\
\hline $135-836 \mathrm{~B}-7 \mathrm{R}-1,31$ & 5 & MICR & 49.17 & 1.12 & 5.36 & 10.40 & 0.29 & 15.66 & 17.68 & 0.20 & 0.02 & 0.03 & 99.93 & 36.9 & 45.4 & 17.7 \\
\hline $135-836 \mathrm{~B}-7 \mathrm{R}-1,31$ & 5 & GLOM & 50.28 & 0.80 & 5.14 & 10.03 & 0.25 & 15.46 & 17.81 & 0.20 & 0.02 & 0.02 & 100.01 & 37.5 & 45.3 & 17.2 \\
\hline $135-836 \mathrm{~B}-7 \mathrm{R}-1,31$ & 5 & PHC & 51.71 & 0.46 & 3.41 & 8.25 & 0.22 & 16.86 & 18.23 & 0.18 & 0.05 & 0.13 & 99.50 & 37.7 & 48.5 & 13.9 \\
\hline $135-836 \mathrm{~B}-7 \mathrm{R}-1,31$ & 5 & PHR & 49.92 & 1.05 & 4.54 & 9.47 & 0.24 & 14.85 & 19.24 & 0.20 & 0.01 & 0.05 & 99.57 & 40.4 & 43.4 & 16.2 \\
\hline $135-836 \mathrm{~B}-9 \mathrm{M}-1,47$ & 5 & $\mathrm{MIC}$ & 53.09 & 0.49 & 2.77 & 9.59 & 0.24 & 17.14 & 16.19 & 0.15 & 0.01 & 0.03 & 99.70 & 34.5 & 49.6 & 15.9 \\
\hline $135-836 \mathrm{~B}-9 \mathrm{M}-1,47$ & 5 & PHC & 53.13 & 0.54 & 3,00 & 9.16 & 0.3 & 17.25 & 16.26 & 0.14 & 0.10 & 0.01 & 99.89 & 34.7 & 50.0 & 15.3 \\
\hline $135-836 \mathrm{~B}-9 \mathrm{M}-1,47$ & 5 & $\mathrm{PHC}$ & 52.93 & 0.52 & 3.27 & 10.10 & 0.34 & 18.49 & 14.30 & 0.12 & 0.03 & 0.07 & 100.17 & 30.2 & 53.1 & 16.7 \\
\hline $135-836 \mathrm{~B}-9 \mathrm{M}-1,47$ & 5 & $\mathrm{PHC}$ & 52.22 & 0.45 & 2.42 & 10.67 & 0.36 & 18.32 & 14.70 & 0.13 & 0.06 & 0.00 & 99.33 & 30.1 & 52.2 & 17.7 \\
\hline $135-836 \mathrm{~B}-9 \mathrm{M}-1,47$ & 5 & PHR & 51.06 & 0.58 & 2.72 & 12.52 & 0.32 & 17.26 & 14.61 & 0.16 & 0.00 & 0.00 & 99.23 & 30.0 & 49.4 & 20.6 \\
\hline $135-836 \mathrm{~B}-9 \mathrm{M}-1,47$ & 5 & OPHC & 50.68 & 0.58 & 3.46 & 9.39 & 0.26 & 15.50 & 18.92 & 0.18 & 0.00 & 0.03 & 99.00 & 39.4 & 44.9 & 15.7 \\
\hline $135-836 \mathrm{~B}-9 \mathrm{M}-1,47$ & 5 & OPHR & 49.61 & 0.65 & 3.65 & 9.71 & 0.35 & 15.94 & 18.04 & 0.20 & 0.02 & 0.08 & 98.25 & 37.5 & 46.1 & 16.4 \\
\hline $135-836 \mathrm{~B}-9 \mathrm{M}-1,47$ & 5 & GRND & 51.63 & 0.65 & 3.33 & 10.60 & 0.35 & 16.21 & 16.51 & 0.18 & 0.08 & 0.10 & 99.64 & 35.3 & 47.0 & 17.7 \\
\hline $135-839 \mathrm{~B}-18 \mathrm{R}-1,54$ & 2 & MIC & 50.17 & 0.80 & 4.62 & 11.60 & 0.29 & 15.54 & 18.31 & 0.19 & 0.05 & 0.04 & 101.61 & 38.0 & 44.9 & 17.1 \\
\hline $135-839 \mathrm{~B}-18 \mathrm{R}-1.54$ & 2 & MIC & 51.38 & 0.50 & 3.46 & 10.61 & 0.35 & 16.04 & 17.78 & 0.16 & 0.03 & 0.06 & 100.37 & 36.5 & 45.9 & 17.6 \\
\hline $135-839 \mathrm{~B}-18 \mathrm{R}-1,54$ & 2 & $\mathrm{OPH}$ & 48.32 & 1.08 & 4.55 & 14.87 & 0.32 & 11.50 & 19.28 & 0.29 & 0.00 & 0.00 & 100.21 & 40.1 & 35.8 & 25.1 \\
\hline $135-839 \mathrm{~B}-18 \mathrm{R}-1,54$ & 2 & GLO & 51.33 & 0.54 & 3.55 & 9.20 & 0.31 & 15.89 & 19.84 & 0.17 & 0.02 & 0.08 & 100.93 & 39.8 & 45.1 & 15.2 \\
\hline $135-839 \mathrm{~B}-18 \mathrm{R}-1,54$ & 2 & GRND & 51.27 & 0.38 & 1.86 & 16.20 & 0.45 & 20.12 & 8.36 & 0.09 & 0.01 & 0.01 & 98.75 & 16.9 & 56.7 & 26.4 \\
\hline $135-839 \mathrm{~B}-18 \mathrm{R}-1,54$ & 2 & PHC & 54.02 & 0.14 & 0.68 & 15.21 & 0.43 & 25,35 & 3.26 & 0.03 & 0.02 & 0.01 & 99.15 & 6.4 & 69.5 & 24.1 \\
\hline $135-839 \mathrm{~B}-18 \mathrm{R}-1,54$ & 4 & $\mathrm{MIC}$ & 52.57 & 0.22 & 1.32 & 14.96 & 0.48 & 23.60 & 5.62 & 0.03 & 0.06 & 0.00 & 98.86 & 11.1 & 65.0 & 23.9 \\
\hline $135-839 \mathrm{~B}-26 \mathrm{R}-1,23$ & 4 & $\mathrm{PHC}$ & 50.44 & 0.49 & 4.31 & 4.63 & 0.15 & 16.63 & 21.18 & 0.16 & 0.02 & 0.70 & 98.71 & 44.1 & 48.2 & 7.8 \\
\hline $135-839 \mathrm{~B}-26 \mathrm{R}-1,23$ & 4 & $\mathrm{PHC}$ & 51.95 & 0.30 & 3.15 & 4.42 & 0.13 & 18.26 & 19.94 & 0.14 & 0.05 & 0.99 & 99.33 & 40.8 & 52.0 & 7.3 \\
\hline $135-839 \mathrm{~B}-26 \mathrm{R}-1,23$ & 4 & $\mathrm{PHC}$ & 51.96 & 0.28 & 3.18 & 4.91 & 0.15 & 17.31 & 21.00 & 0.11 & 0.02 & 0.26 & 99.18 & 42.8 & 49.1 & 8.1 \\
\hline $135-839 \mathrm{~B}-26 \mathrm{R}-1,23$ & 4 & PHR & 49.33 & 0.65 & 5.40 & 6.88 & 0.11 & 15.17 & 20.74 & 0.11 & 0.02 & 0.06 & 98.47 & 43.9 & 44.6 & 11.5 \\
\hline 135-839B-26R-1, 23 & 4 & $\mathrm{PHC}$ & 51.21 & 0.33 & 4.10 & 5.14 & 0.15 & 16.46 & 20.95 & 0.10 & 0.03 & 0.22 & 98.69 & 43.7 & 47.7 & 8.6 \\
\hline $135-839 \mathrm{~B}-26 \mathrm{R}-1,23$ & 4 & PHC & 53.06 & 0.21 & 2.39 & 4.66 & 0.17 & 19.47 & 18.64 & 0.10 & 0.03 & 0.87 & 99.60 & 37.7 & 54.7 & 7.6 \\
\hline $135-839 \mathrm{~B}-26 \mathrm{R}-1,23$ & 4 & PHR & 52.28 & 0.23 & 3.31 & 4.83 & 0.16 & 17.49 & 20.74 & 0.11 & 0.02 & 0.32 & 99.49 & 42.4 & 49.7 & 8.0 \\
\hline $135-839 \mathrm{~B}-27 \mathrm{R}-1,15$ & 5 & PHC & 54.08 & 0.15 & 1.22 & 15.31 & 0.40 & 26.80 & 2.05 & 0.00 & 0.02 & 0.01 & 100.04 & 4.0 & 72.3 & 23.8 \\
\hline $135-839 \mathrm{~B}-27 \mathrm{R}-1,15$ & 4 & PHC & 54.20 & 0.18 & 1.21 & 14.98 & 0.39 & 27.06 & 1.93 & 0.00 & 0.03 & 0.00 & 99.98 & 3.7 & 73.0 & 23.3 \\
\hline $135-839 \mathrm{~B}-27 \mathrm{R}-1,15$ & 5 & $\mathrm{PHC}$ & 54.01 & 0.17 & 1.46 & 14.67 & 0.35 & 27.13 & 1.80 & 0.02 & 0.04 & 0.05 & 99.70 & 3.5 & 73.6 & 22.9 \\
\hline $135-839 \mathrm{~B}-27 \mathrm{R}-1,15$ & 5 & PHC & 54.12 & 0.18 & 1.60 & 14.94 & 0.33 & 26.48 & 2.22 & 0.01 & 0.00 & 0.06 & 99.94 & 4.4 & 72.3 & 23.4 \\
\hline $135-839 \mathrm{~B}-27 \mathrm{R}-1,15$ & 5 & PHR & 53.07 & 0.15 & 1.47 & 15.39 & 0.40 & 25.93 & 2.16 & 0.01 & 0.02 & 0.03 & 98.63 & 4.3 & 71.3 & 24.4 \\
\hline $135-839 \mathrm{~B}-30 \mathrm{R}-1,74$ & 9 & PHC & 52.39 & 0.27 & 1.91 & 14.78 & 0.40 & 24.94 & 4.52 & 0.01 & 0.02 & 0.02 & 99.26 & 8.9 & 67.9 & 23.2 \\
\hline $135-839 \mathrm{~B}-30 \mathrm{R}-1,74$ & 9 & PHR & 51.81 & 0.27 & 2.14 & 17.49 & 0.36 & 24.88 & 2.06 & 0.02 & 0.01 & 0.04 & 99.08 & 4.1 & 68.4 & 27.5 \\
\hline $135-839 \mathrm{~B}-30 \mathrm{R}-1,74$ & 9 & PHC & 53.61 & 0.31 & 3.91 & 12.37 & 0.34 & $\begin{array}{l}24.000 \\
20.31\end{array}$ & 7.61 & 0.37 & 0.01 & 0.02 & 98.86 & 16.6 & 61.7 & 21.7 \\
\hline $135-839 \mathrm{~B}-30 \mathrm{R}-1,74$ & 9 & PHR & 51.53 & 0.49 & 2.39 & 19.44 & 0.43 & 20.02 & 4.23 & 0.05 & 0.01 & 0.03 & 98.62 & 8.9 & 58.5 & 32.6 \\
\hline $135-839 \mathrm{~B}-30 \mathrm{R}-1,74$ & 9 & MIC & 54.14 & 0.19 & 1.17 & 16.52 & 0.37 & 26.04 & 2.17 & 0.01 & 0.02 & 0.01 & 100.64 & 4.2 & 70.2 & 25.6 \\
\hline $135-839 \mathrm{~B}-30 \mathrm{R}-1,74$ & 9 & MICR & 53.54 & 0.27 & 1.78 & 17.46 & 0.38 & 24.59 & 2.37 & 0.07 & 0.05 & 0.02 & 100.53 & 4.7 & 67.7 & 27.6 \\
\hline $135-839 \mathrm{~B}-30 \mathrm{R}-1,74$ & 9 & MIC & 49.84 & 0.58 & 3.00 & 14.95 & 0.30 & 15.27 & 15.44 & 0.19 & 0.01 & 0.02 & 99.60 & 31.8 & 43.7 & 24.5 \\
\hline $135-839 \mathrm{~B}-30 \mathrm{R}-1,74$ & 9 & MIC & 51.69 & 0.40 & 2.56 & 10.99 & 0.35 & 17.37 & 15.70 & 0.16 & 0.03 & 0.00 & 99.25 & 32.2 & 49.6 & 18.2 \\
\hline 135-839B-30R-1, 74 & 9 & MIC & 50.16 & 0.57 & 2.83 & 13.06 & 0.38 & 15.56 & 16.17 & 0.14 & 0.02 & 0.02 & 98.91 & 33.5 & 44.8 & 21.7 \\
\hline $135-839$ B-30R-1, 74 & 9 & MIC & 46.12 & 2.04 & 3.36 & 24.51 & 0.55 & 10.27 & 12.60 & 0.22 & 0.04 & 0.04 & 99.75 & 27.1 & 30.8 & 42.1 \\
\hline
\end{tabular}

Note: Forms as described in Appendix C. 
APPENDIX E

Microprobe Analyses for Olivine, Sites 834, 835, and 839

\begin{tabular}{|c|c|c|c|c|c|c|c|c|c|c|c|c|}
\hline $\begin{array}{l}\text { Core, section, } \\
\text { interval (cm) }\end{array}$ & Form & $\mathrm{SiO}_{2}$ & $\mathrm{FeO}$ & $\mathrm{MgO}$ & $\mathrm{MnO}$ & $\mathrm{CaO}$ & $\mathrm{Al}_{2} \mathrm{O}_{3}$ & $\mathrm{NiO}$ & $\mathrm{Cr}_{2} \mathrm{O}_{3}$ & Sum & FO & FA \\
\hline $135-834 \mathrm{~A}-12 \mathrm{X}-\mathrm{CC}, 2$ & PHC & 39.89 & 12.57 & 46.81 & 0.22 & 0.31 & 0.03 & 0.13 & 0.00 & 99.96 & 86.9 & 13.1 \\
\hline $135-834 \mathrm{~A}-12 \mathrm{X}-\mathrm{CC}, 2$ & PHR & 39.46 & 12.83 & 46.23 & 0.26 & 0.37 & 0.08 & 0.10 & 0.03 & 99.36 & 86.5 & 13.5 \\
\hline $135-834 \mathrm{~A}-12 \mathrm{X}-\mathrm{CC}, 2$ & PHC & 39.75 & 13.15 & 46.22 & 0.23 & 0.34 & 0.02 & 0.13 & 0.05 & 99.89 & 86.2 & 13.8 \\
\hline $135-834 \mathrm{~A}-12 \mathrm{X}-\mathrm{CC}, 2$ & PHC & 39.01 & 13.23 & 45.59 & 0.21 & 0.38 & 0.05 & 0.09 & 0.06 & 98.62 & 86.0 & 14.0 \\
\hline $135-834 \mathrm{~A}-12 \mathrm{X}-\mathrm{CC}, 2$ & PHC & 39.74 & 13.46 & 45.69 & 0.21 & 0.37 & 0.05 & 0.06 & 0.04 & 99.62 & 85.8 & 14.2 \\
\hline $135-834 \mathrm{~A}-14 \mathrm{X}-6,7$ & MIC & 38.89 & 18.24 & 41.98 & 0.31 & 0.30 & 0.01 & 0.05 & 0.01 & 99.79 & 80.4 & 19.6 \\
\hline $135-834 \mathrm{~A}-14 \mathrm{X}-6,7$ & MIC & 38.14 & 17.91 & 41.85 & 0.31 & 0.31 & 0.00 & 0.02 & 0.02 & 98.56 & 80.6 & 19.4 \\
\hline $135-834 \mathrm{~B}-14 \mathrm{R}-1,32$ & PHC & 38.92 & 19.20 & 41.80 & 0.33 & 0.28 & 0.01 & 0.09 & 0.01 & 100.64 & 79.5 & 20.5 \\
\hline $135-834 \mathrm{~B}-14 \mathrm{R}-1,32$ & PHR & 38.67 & 19.41 & 41.29 & 0.33 & 0.28 & 0.02 & 0.08 & 0.00 & 100.08 & 79.1 & 20.9 \\
\hline $135-834 \mathrm{~B}-15 \mathrm{R}-2,35$ & PHC & 38.55 & 19.50 & 40.67 & 0.34 & 0.28 & 0.00 & 0.07 & 0.00 & 99.41 & 78.8 & 21.2 \\
\hline $135-834 \mathrm{~B}-15 \mathrm{R}-2,35$ & PHR & 39.24 & 19.85 & 41.35 & 0.36 & 0.29 & 0.00 & 0.05 & 0.03 & 101.17 & 78.8 & 21.2 \\
\hline $135-834 \mathrm{~B}-15 \mathrm{R}-2,35$ & PHC & 38.61 & 18.02 & 42.05 & 0.36 & 0.29 & 0.00 & 0.11 & 0.03 & 99.47 & 80.6 & 19.4 \\
\hline $135-834 \mathrm{~B}-15 \mathrm{R}-2,35$ & PHR & 38.14 & 17.98 & 41.32 & 0.31 & 0.29 & 0.00 & 0.09 & 0.00 & 98.13 & 80.4 & 19.6 \\
\hline $135-834 \mathrm{~B}-15 \mathrm{R}-2,56$ & $\mathrm{PHC}$ & 39.69 & 16.14 & 43.93 & 0.28 & 0.29 & 0.01 & 0.09 & 0.06 & 100.49 & 82.9 & 17.1 \\
\hline $135-834 \mathrm{~B}-15 \mathrm{R}-2,56$ & PHR & 39.71 & 17.68 & 43.34 & 0.34 & 0.28 & 0.00 & 0.08 & 0.04 & 101.47 & 81.4 & 18.6 \\
\hline $135-834 \mathrm{~B}-15 \mathrm{R}-2,56$ & MIC & 39.19 & 17.17 & 43.16 & 0.29 & 0.28 & 0.09 & 0.07 & 0.04 & 100.29 & 81.8 & 18.2 \\
\hline $135-834 \mathrm{~B}-15 \mathrm{R}-2,56$ & MICR & 38.44 & 16.45 & 42.26 & 0.30 & 0.34 & 0.02 & 0.07 & 0.01 & 97.89 & 82.1 & 17.9 \\
\hline $135-834 \mathrm{~B}-28 \mathrm{R}-1,42$ & $\mathrm{PHC}$ & 39.58 & 12.00 & 46.72 & 0.23 & 0.32 & 0.00 & 0.16 & 0.07 & 99.08 & 87.4 & 12.6 \\
\hline $135-834 \mathrm{~B}-28 \mathrm{R}-1,42$ & MIC & 38.12 & 16.90 & 42.67 & 0.34 & 0.48 & 0.04 & 0.03 & 0.08 & 98.66 & 81.8 & 18.2 \\
\hline $135-834 \mathrm{~B}-28 \mathrm{R}-1,42$ & MIC & 38.30 & 17.41 & 41.62 & 0.32 & 0.49 & 0.00 & 0.12 & 0.06 & 98.32 & 81.0 & 19.0 \\
\hline $135-834 \mathrm{~B}-30 \mathrm{R}-3,105$ & MIC & 39.99 & 12.82 & 46.38 & 0.22 & 0.32 & 0.00 & 0.08 & 0.07 & 99.88 & 86.6 & 13.4 \\
\hline $135-834 \mathrm{~B}-30 \mathrm{R}-3,105$ & MIC & 39.86 & 13.86 & 45.34 & 0.24 & 0.38 & 0.08 & 0.11 & 0.06 & 99.93 & 85.4 & 14.6 \\
\hline $135-834 \mathrm{~B}-30 \mathrm{R}-3,105$ & MIC & 39.57 & 13.36 & 46.42 & 0.27 & 0.33 & 0.06 & 0.11 & 0.08 & 100.20 & 86.1 & 13.9 \\
\hline $135-834 \mathrm{~B}-30 \mathrm{R}-3,105$ & GRND & 39.66 & 12.64 & 46.12 & 0.24 & 0.36 & 0.00 & 0.16 & 0.04 & 99.22 & 86.7 & 13.3 \\
\hline $135-834 \mathrm{~B}-30 \mathrm{R}-3,105$ & PHC & 39.95 & 11.53 & 47.84 & 0.20 & 0.33 & 0.00 & 0.17 & 0.02 & 100.04 & 88.1 & 11.9 \\
\hline $135-834 \mathrm{~B}-30 \mathrm{R}-3,105$ & PHI & 39.53 & 11.98 & 47.79 & 0.20 & 0.34 & 0.02 & 0.18 & 0.07 & 100.11 & 87.7 & 12.3 \\
\hline $135-834 \mathrm{~B}-30 \mathrm{R}-3,105$ & PHR & 40.58 & 12.63 & 47.16 & 0.25 & 0.35 & 0.03 & 0.15 & 0.06 & 101.21 & 86.9 & 13.1 \\
\hline $135-834 \mathrm{~B}-30 \mathrm{R}-3,105$ & PHC & 40.39 & 11.18 & 47.63 & 0.19 & 0.33 & 0.00 & 0.34 & 0.15 & 100.21 & 88.4 & 11.6 \\
\hline $135-834 \mathrm{~B}-30 \mathrm{R}-3,105$ & PHR & 40.75 & 12.15 & 47.78 & 0.19 & 0.33 & 0.05 & 0.33 & 0.12 & 101.70 & 87.5 & 12.5 \\
\hline $135-834 \mathrm{~B}-31 \mathrm{R}-2,43$ & PHC & 40.12 & 12.71 & 46.91 & 0.20 & 0.33 & 0.03 & 0.10 & 0.07 & 100.47 & 86.8 & 13.2 \\
\hline $135-834 \mathrm{~B}-31 \mathrm{R}-2,43$ & PHR & 41.54 & 12.13 & 46.43 & 0.24 & 0.37 & 0.60 & 0.15 & 0.01 & 101.47 & 87.2 & 12.8 \\
\hline $135-834 \mathrm{~B}-31 \mathrm{R}-2,43$ & PHC & 40.13 & 12.84 & 46.89 & 0.26 & 0.34 & 0.02 & 0.11 & 0.01 & 100.60 & 86.7 & 13.3 \\
\hline $135-834 \mathrm{~B}-31 \mathrm{R}-2,43$ & PHR & 39.94 & 12.20 & 46.73 & 0.18 & 0.33 & 0.03 & 0.14 & 0.07 & 99.62 & 87.2 & 12.8 \\
\hline $135-834 \mathrm{~B}-31 \mathrm{R}-2,43$ & PHC & 40.15 & 12.45 & 46.32 & 0.21 & 0.37 & 0.03 & 0.16 & 0.07 & 99.76 & 86.9 & 13.1 \\
\hline $135-834 \mathrm{~B}-31 \mathrm{R}-2,43$ & PHR & 41.45 & 12.72 & 46.10 & 0.25 & 0.70 & 0.34 & 0.14 & 0.08 & 101.78 & 86.6 & 13.4 \\
\hline $135-834 \mathrm{~B}-35 \mathrm{R}-2,121$ & GRND & 39.58 & 13.83 & 45.20 & 0.27 & 0.30 & 0.04 & 0.10 & 0.04 & 99.36 & 85.3 & 14.7 \\
\hline $135-834 \mathrm{~B}-35 \mathrm{R}-2,121$ & GRND & 39.60 & 15.18 & 44.60 & 0.26 & 0.29 & 0.00 & 0.09 & 0.04 & 100.06 & 84.0 & 16.0 \\
\hline $135-834 \mathrm{~B}-35 \mathrm{R}-2,121$ & GRND & 39.27 & 15.14 & 44.47 & 0.26 & 0.31 & 0.00 & 0.10 & 0.04 & 99.59 & 84.0 & 16.0 \\
\hline $135-834 \mathrm{~B}-35 \mathrm{R}-2,121$ & PHC & 40.01 & 13.33 & 46.31 & 0.16 & 0.28 & 0.00 & 0.13 & 0.08 & 100.30 & 86.1 & 13.9 \\
\hline $135-834 \mathrm{~B}-35 \mathrm{R}-2,121$ & PHI & 40.28 & 13.13 & 46.33 & 0.26 & 0.25 & 0.00 & 0.13 & 0.05 & 100.43 & 86.3 & 13.7 \\
\hline $135-834 \mathrm{~B}-35 \mathrm{R}-2,121$ & PHR & 39.64 & 13.59 & 46.04 & 0.23 & 0.25 & 0.00 & 0.15 & 0.06 & 99.96 & 85.8 & 14.2 \\
\hline $135-834 \mathrm{~B}-35 \mathrm{R}-2,121$ & PHR & 39.41 & 15.21 & 44.48 & 0.24 & 0.27 & 0.01 & 0.07 & 0.00 & 99.69 & 83.9 & 16.1 \\
\hline $135-834 \mathrm{~B}-36 \mathrm{R}-1,0$ & PHC & 39.38 & 13.91 & 46.07 & 0.22 & 0.27 & 0.36 & 0.09 & 0.00 & 100.30 & 85.5 & 14.5 \\
\hline $135-834 \mathrm{~B}-36 \mathrm{R}-1,0$ & PHR & 39.41 & 14.99 & 44.57 & 0.29 & 0.28 & 0.03 & 0.41 & 0.00 & 99.98 & 84.1 & 15.9 \\
\hline $135-834 \mathrm{~B}-37 \mathrm{R}-1,46$ & PHC & 39.87 & 13.50 & 46.17 & 0.19 & 0.31 & 0.04 & 0.15 & 0.05 & 100.28 & 85.9 & 14.1 \\
\hline $135-834 \mathrm{~B}-37 \mathrm{R}-1,46$ & PHR & 38.79 & 15.89 & 43.72 & 0.33 & 0.32 & 0.03 & 0.14 & 0.03 & 99.25 & 83.1 & 16.9 \\
\hline $135-834 \mathrm{~B}-37 \mathrm{R}-1,46$ & PHC & 39.49 & 13.42 & 46.13 & 0.23 & 0.31 & 0.01 & 0.13 & 0.07 & 99.79 & 86.0 & 14.0 \\
\hline $135-834 \mathrm{~B}-37 \mathrm{R}-1,46$ & PHR & 40.02 & 13.55 & 46.52 & 0.27 & 0.35 & 0.00 & 0.15 & 0.05 & 100.91 & 86.0 & 14.0 \\
\hline $135-834 \mathrm{~B}-37 \mathrm{R}-1,46$ & GRND & 39.69 & 14.61 & 45.23 & 0.28 & 0.30 & 0.02 & 0.13 & 0.08 & 100.34 & 84.7 & 15.3 \\
\hline 135-834B-39R-1, 0 & $\mathrm{PHC}$ & 38.33 & 21.52 & 39.87 & 0.39 & 0.26 & 0.00 & & 0.01 & 100.38 & 76.8 & 23.2 \\
\hline $135-834 \mathrm{~B}-39 \mathrm{R}-1,0$ & PHR & 39.07 & 21.57 & 40.08 & 0.37 & 0.28 & 0.01 & 0.10 & 0.03 & 101.51 & 76.8 & 23.2 \\
\hline $135-834 \mathrm{~B}-46 \mathrm{R}-1,37$ & MIC & 39.27 & 13.58 & 45.72 & 0.27 & 0.31 & 0.06 & 0.03 & 0.06 & 99.42 & 85.7 & 14.3 \\
\hline $135-834 \mathrm{~B}-46 \mathrm{R}-1,37$ & MIC & 39.51 & 14.05 & 45.85 & 0.30 & 0.33 & 0.00 & 0.08 & 0.03 & 100.15 & 85.3 & 14.7 \\
\hline $135-834 \mathrm{~B}-46 \mathrm{R}-1,37$ & PHC & 39.43 & 13.71 & 45.89 & 0.25 & 0.28 & 0.20 & 0.08 & 0.20 & 100.04 & 85.6 & 14.4 \\
\hline $135-834 \mathrm{~B}-46 \mathrm{R}-1,37$ & PHC & 39.80 & 13.55 & 45.99 & 0.23 & 0.30 & 0.01 & 0.14 & 0.05 & 100.07 & 85.8 & 14.2 \\
\hline $135-834 \mathrm{~B}-47 \mathrm{R}-1,130$ & MIC & 37.15 & 28.96 & 33.88 & 0.50 & 0.26 & 0.00 & 0.04 & 0.01 & 100.80 & 67.6 & 32.4 \\
\hline $135-834 \mathrm{~B}-47 \mathrm{R}-1,130$ & MICR & 35.85 & 29.19 & 32.69 & 0.56 & 0.26 & 0.00 & 0.01 & 0.03 & 98.59 & 66.6 & 33.4 \\
\hline $135-834 \mathrm{~B}-47 \mathrm{R}-1,130$ & MIC & 36.52 & 28.90 & 33.50 & 0.50 & 0.26 & 0.00 & 0.05 & 0.01 & 99.74 & 67.4 & 32.6 \\
\hline $135-834 \mathrm{~B}-54 \mathrm{R}-1,5$ & PHC & 36.89 & 28.33 & 33.99 & 0.54 & 0.25 & 0.00 & 0.03 & 0.04 & 100.07 & 68.1 & 31.9 \\
\hline $135-834 \mathrm{~B}-54 \mathrm{R}-1,5$ & PHR & 36.89 & 28.78 & 33.28 & 0.50 & 0.29 & 0.01 & 0.01 & 0.02 & 99.78 & 67.3 & 32.7 \\
\hline 135-834B-56R-1, 7 & PHC & 37.49 & 27.86 & 33.83 & 0.52 & 0.30 & 0.00 & 0.01 & 0.01 & 100.02 & 68.4 & 31.6 \\
\hline 135-834B-56R-1, 7 & SKEL & 37.75 & 29.21 & 33.87 & 0.52 & 0.25 & 0.01 & 0.00 & 0.00 & 101.61 & 67.4 & 32.6 \\
\hline 135-834B-57R-1, 0 & PHC & 37.38 & 28.15 & 34.35 & 0.47 & 0.26 & 0.03 & 0.03 & 0.01 & 100.68 & 68.5 & 31.5 \\
\hline $135-834 \mathrm{~B}-57 \mathrm{R}-1,0$ & PHR & 37.02 & 28.74 & 33.57 & 0.48 & 0.31 & 0.00 & 0.00 & 0.04 & 100.16 & 67.6 & 32.4 \\
\hline 135-835B-3R-1, 137 & PHC & 39.69 & 14.85 & 44.88 & 0.29 & 0.28 & 0.00 & 0.24 & 0.08 & 100.31 & 84.3 & 15.7 \\
\hline $135-835 \mathrm{~B}-3 \mathrm{R}-1,137$ & PHR & 39.05 & 15.93 & 43.23 & 0.27 & 0.32 & 0.09 & 0.20 & 0.02 & 99.11 & 82.9 & 17.1 \\
\hline 135-835B-3R-1, 137 & PHC & 40.09 & 12.41 & 47.16 & 0.21 & 0.25 & 0.00 & 0.33 & 0.00 & 100.45 & 87.1 & 12.9 \\
\hline $135-835 \mathrm{~B}-3 \mathrm{R}-1,137$ & PHR & 39.38 & 15.47 & 44.02 & 0.30 & 0.27 & 0.00 & 0.24 & 0.03 & 99.71 & 83.5 & 16.5 \\
\hline $135-835 \mathrm{~B}-3 \mathrm{R}-2,4$ & PHC & 39.64 & 14.18 & 44.89 & 0.23 & 0.29 & 0.07 & 0.08 & 0.02 & 99.40 & 84.9 & 15.1 \\
\hline $135-835 B-3 R-2,4$ & PHR & 40.12 & 15.48 & 44.79 & 0.30 & 0.28 & 0.00 & 0.10 & 0.02 & 101.09 & 83.8 & 16.2 \\
\hline $135-835 B-3 R-2,4$ & PHC & 39.2 & 15.73 & 43.75 & 0.26 & 0.26 & 0.04 & 0.08 & 0.00 & 99.32 & 83.2 & 16.8 \\
\hline 135 & PHR & 40.00 & 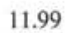 & 4 & 0 & 0 & 0 & 0.1 & 0 & 1 & 87.6 & 12.4 \\
\hline $135-839 \mathrm{~B}-22 \mathrm{R}-1,19$ & PHC & 40.74 & 9.58 & 49 . & 0.21 & 0.23 & 0.00 & 0.22 & 0.06 & 100.30 & 90.2 & 9.8 \\
\hline 135-839B-22R-1, 19 & PHR & 39.71 & 13.56 & 45.75 & 0.22 & 0.30 & 0.02 & 0.09 & 0.04 & 99.69 & 85.7 & 14.3 \\
\hline $135-839 \mathrm{~B}-22 \mathrm{R}-1,24$ & PHC & 40.59 & 10.74 & 48.52 & 0.18 & 0.23 & 0.00 & 0.19 & 0.03 & 100.48 & 89.0 & 11.0 \\
\hline $135-839 \mathrm{~B}-22 \mathrm{R}-1,24$ & PHR & 39.54 & 12.70 & 46.54 & 0.24 & 0.32 & 0.01 & 0.10 & 0.07 & 99.52 & 86.7 & 13.3 \\
\hline $135-839 \mathrm{~B}-22 \mathrm{R}-1,24$ & PHC & 39.78 & 10.99 & 47.52 & 0.21 & 0.25 & 0.02 & 0.16 & 0.06 & 98.99 & 88.5 & 11.5 \\
\hline $135-839 \mathrm{~B}-22 \mathrm{R}-1,24$ & PHR & 40.26 & 12.79 & 44.58 & 0.24 & 0.87 & 0.84 & 0.12 & 0.07 & 99.77 & 86.1 & 13.9 \\
\hline $135-839 \mathrm{~B}-22 \mathrm{R}-1,30$ & $\mathrm{PHC}$ & 40.75 & 10.79 & 48.86 & 0.18 & 0.21 & 0.01 & 0.18 & 0.10 & 101.08 & 89.0 & 11.0 \\
\hline $135-839 \mathrm{~B}-22 \mathrm{R}-1,30$ & PHI & 40.31 & 11.03 & 48.28 & 0.21 & 0.23 & 0.00 & 0.14 & 0.07 & 100.27 & 88.6 & 11.4 \\
\hline $135-839 \mathrm{~B}-22 \mathrm{R}-1,30$ & PHR & 40.21 & 12.46 & 47.01 & 0.25 & 0.28 & 0.04 & 0.16 & 0.11 & 100.52 & 87.1 & 12.9 \\
\hline $135-839 \mathrm{~B}-26 \mathrm{R}-1,23$ & PHC & 40.49 & 10.44 & 48.17 & 0.24 & 0.26 & 0.00 & 0.16 & 0.13 & 99.89 & 89.2 & 10.8 \\
\hline $135-839 \mathrm{~B}-26 \mathrm{R}-1,23$ & PHR & 39.96 & 14.32 & 45.57 & 0.25 & 0.27 & 0.00 & 0.10 & 0.01 & 100.48 & 85.0 & 15.0 \\
\hline
\end{tabular}


APPENDIX E (continued).

\begin{tabular}{ccccccccccccc}
\hline $\begin{array}{c}\text { Core, section, } \\
\text { interval }(\mathrm{cm})\end{array}$ & Form & $\mathrm{SiO}_{2}$ & $\mathrm{FeO}$ & $\mathrm{MgO}$ & $\mathrm{MnO}$ & $\mathrm{CaO}$ & $\mathrm{Al}_{2} \mathrm{O}_{3}$ & $\mathrm{NiO}$ & $\mathrm{Cr}_{2} \mathrm{O}_{3}$ & $\mathrm{Sum}$ & $\mathrm{FO}$ & $\mathrm{FA}$ \\
\hline 135-839B-26R-1,23 & $\mathrm{PHC}$ & 40.33 & 11.02 & 48.17 & 0.20 & 0.24 & 0.00 & 0.17 & 0.15 & 100.28 & 88.6 & 11.4 \\
$135-839 \mathrm{~B}-26 \mathrm{R}-1,23$ & $\mathrm{PHR}$ & 40.41 & 12.03 & 47.60 & 0.17 & 0.24 & 0.00 & 0.11 & 0.05 & 100.61 & 87.6 & 12.4 \\
$135-839 \mathrm{~B}-26 \mathrm{R}-1,23$ & $\mathrm{PHC}$ & 39.88 & 11.93 & 47.50 & 0.28 & 0.23 & 0.00 & 0.14 & 0.03 & 99.99 & 87.6 & 12.4 \\
$135-839 \mathrm{~B}-26 \mathrm{R}-1,23$ & $\mathrm{PHR}$ & 39.35 & 15.79 & 43.82 & 0.25 & 0.39 & 0.25 & 0.07 & 0.03 & 99.95 & 83.2 & 16.8 \\
\hline
\end{tabular}

Note: Forms as described in Appendix C.

APPENDIX F

Selected Cr-spinel Analyses, Sites 834, 836, and 839

\begin{tabular}{|c|c|c|c|c|c|c|c|c|}
\hline Hole: & $834 \mathrm{~A}$ & $834 \mathrm{~B}$ & $836 \mathrm{~A}$ & $839 \mathrm{~A}$ & $839 \mathrm{~A}$ & 839B & $839 \mathrm{~B}$ & $839 \mathrm{~B}$ \\
\hline Core, section: & $12 \mathrm{X}-\mathrm{CC}$ & $26 \mathrm{R}-1$ & $5 X-1$ & $24 X-1$ & $24 X-1$ & $25 \mathrm{R}-1$ & $25 \mathrm{R}-1$ & 25R-1 \\
\hline Interval $(\mathrm{cm})$ : & $0-3$ & $53-65$ & $37-40$ & $19-22$ & $19-22$ & $35-38$ & $35-38$ & $43-45$ \\
\hline Analysis no.: & 1 & 2 & 3 & 4 & 5 & 6 & 7 & 8 \\
\hline Description: & IPC & G & IPC & PC & PR & PC & PR & IO \\
\hline Unit: & 1 & 7 & 3 & 1 & 1 & 3 & 3 & 4 \\
\hline $\mathrm{SiO}_{2}$ & 0.07 & 0.03 & 0.02 & 0.01 & 0.06 & 0.03 & 0.08 & 0.02 \\
\hline $\mathrm{TiO}_{2}^{2}$ & 0.98 & 0.69 & 0.37 & 0.25 & 0.27 & 0.25 & 0.33 & 0.37 \\
\hline $\mathrm{Al}_{2} \mathrm{O}_{3}$ & 26.68 & 27.63 & 27.44 & 13.55 & 12.13 & 11.15 & 11.05 & 14.45 \\
\hline $\mathrm{V}_{2} \mathrm{O}_{3}$ & 0.23 & 0.13 & 0.15 & 0.12 & 0.12 & 0.08 & 0.06 & 0.19 \\
\hline $\mathrm{Cr}_{2} \mathrm{O}_{3}$ & 35.03 & 36.00 & 35.85 & 55.04 & 52.70 & 56.43 & 54.06 & 48.65 \\
\hline $\mathrm{FeO}$ & 22.09 & 19.47 & 20.13 & 15.72 & 24.16 & 16.41 & 21.38 & 21.71 \\
\hline $\mathrm{MnO}$ & 0.17 & 0.10 & 0.11 & 0.05 & 0.17 & 0.07 & 0.17 & 0.10 \\
\hline $\mathrm{NiO}$ & 0.09 & 0.19 & 0.14 & 0.21 & 0.14 & 0.13 & 0.09 & 0.09 \\
\hline $\mathrm{ZnO}$ & & & 0.06 & & & & 0.08 & \\
\hline $\mathrm{MgO}$ & 14.27 & 14.89 & 14.99 & 15.28 & 9.97 & 15.55 & 11.97 & 12.90 \\
\hline $\mathrm{CaO}$ & 0.10 & 0.12 & 0.12 & 0.02 & 0.11 & 0.00 & 0.06 & 0.02 \\
\hline Total & 99.69 & 99.25 & 99.38 & 100.25 & 99.82 & 100.10 & 99.33 & 98.51 \\
\hline $\mathrm{RFe}_{2} \mathrm{O}_{3}$ & 7.77 & 6.35 & 7.58 & 5.28 & 6.09 & 6.84 & 6.64 & 8.09 \\
\hline $\mathrm{RFeO}$ & 15.09 & 13.75 & 13.31 & 10.97 & 18.68 & 10.26 & 15.40 & 14.43 \\
\hline RTotal & 100.47 & 99.89 & 100.14 & 100.78 & 100.43 & 100.78 & 100.00 & 99.32 \\
\hline $\mathrm{Cr} / \mathrm{Cr}+\mathrm{Al}$ & 0.468 & 0.466 & 0.467 & 0.731 & 0.744 & 0.772 & 0.766 & 0.693 \\
\hline $\mathrm{Mg} / \mathrm{Mg}+\mathrm{Fe}$ & 0.627 & 0.659 & 0.667 & 0.713 & 0.487 & 0.730 & 0.581 & 0.614 \\
\hline $\mathrm{Fe}^{3} /\left(\mathrm{Cr}+\mathrm{Al}+\mathrm{Fe}^{3+}\right)$ & 0.090 & 0.073 & 0.086 & 0.063 & 0.076 & 0.082 & 0.082 & 0.099 \\
\hline $\mathrm{Cr} /\left(\mathrm{Cr}+\mathrm{Al}+\mathrm{Fe}^{3+}\right)$ & 0.426 & 0.432 & 0.427 & 0.686 & 0.688 & 0.709 & 0.703 & 0.625 \\
\hline $\mathrm{Al} /\left(\mathrm{Cr}+\mathrm{Al}+\mathrm{Fe}^{3+}\right)$ & 0.484 & 0.495 & 0.487 & 0.252 & 0.236 & 0.209 & 0.214 & 0.277 \\
\hline
\end{tabular}

Notes: $\mathrm{RFe}_{2} \mathrm{O}_{3}$ and $\mathrm{RFeO}$ represent recalculated values based on stoichiometry. $\mathrm{V}_{2} \mathrm{O}_{3}$ corrected for $\mathrm{Ti}$ peak overlap. $\mathrm{IPC}=$ inclusion in plagioclase, $\mathrm{G}=$ groundmass, $\mathrm{PR}=$ phenocryst $(\mathrm{rim}), \mathrm{PC}=$ phenocryst (core), and $\mathrm{IO}=$ inclusion in olivine.

APPENDIX G

Selected Ti-rich Magnetite Analyses, Sites 834, 836, 837, and 839

\begin{tabular}{|c|c|c|c|c|c|c|c|c|c|}
\hline Hole: & $834 \mathrm{~B}$ & $836 \mathrm{~B}$ & 837B & 837B & 837B & $837 \mathrm{~B}$ & $839 \mathrm{~A}$ & 839B & $839 \mathrm{~B}$ \\
\hline Core, section: & $28 \mathrm{R}-1$ & $6 \mathrm{R}-2$ & $2 \mathrm{R}-1$ & $2 \mathrm{R}-1$ & $5 \mathrm{R}-1$ & $5 \mathrm{R}-1$ & $24 \mathrm{X}-1$ & $16 R-1$ & $25 \mathrm{R}-1$ \\
\hline Interval $(\mathrm{cm})$ : & $35-42$ & $59-63$ & $24-26$ & $24-26$ & $66-69$ & $66-69$ & $19-22$ & $60-63$ & $43-45$ \\
\hline Analysis no.: & 9 & 10 & 11 & 12 & 13 & 14 & 15 & 16 & 17 \\
\hline Description: & G & G & GC & GR & $\mathrm{PC}$ & PR & G & G & G \\
\hline Unit: & 7 & $4 B$ & 1 & 1 & 1 & 1 & 1 & 1 & 4 \\
\hline $\mathrm{SiO}_{2}$ & 0.12 & 0.08 & 0.11 & 0.10 & 0.06 & 0.12 & 0.13 & 0.20 & 0.24 \\
\hline $\mathrm{TiO}_{2}^{2}$ & 23.24 & 20.68 & 12.21 & 12.21 & 9.54 & 11.93 & 14.11 & 16.21 & 11.22 \\
\hline $\mathrm{Al}_{2} \mathrm{O}_{3}$ & 1.77 & 1.23 & 3.39 & 3.29 & 3.57 & 3.17 & 2.69 & 4.21 & 1.63 \\
\hline $\mathrm{V}_{2} \mathrm{O}_{3}$ & 0.41 & 0.89 & 1.30 & 1.34 & 1.19 & 1.25 & 1.46 & 0.78 & 0.57 \\
\hline $\mathrm{Cr}_{2} \mathrm{O}_{3}$ & 0.05 & 0.10 & 0.15 & 0.25 & 0.14 & 0.19 & vi.i4 & 0.08 & 0.07 \\
\hline $\mathrm{FeO}$ & 69.91 & 74.01 & 76.30 & 76.77 & 79.42 & 78.60 & 76.46 & 73.84 & 79.48 \\
\hline $\mathrm{MnO}$ & 0.65 & 0.39 & 0.31 & 0.32 & 0.29 & 0.27 & 0.33 & 0.39 & 0.26 \\
\hline $\mathrm{NiO}$ & 0.01 & 0.07 & 0.01 & 0.02 & 0.01 & 0.04 & 0.01 & 0.01 & 0.00 \\
\hline $\mathrm{ZnO}$ & 0.00 & 0.17 & 0.00 & 0.14 & 0.08 & 0.00 & 0.00 & 0.00 & 0.00 \\
\hline $\mathrm{MgO}$ & 0.71 & 0.97 & 2.72 & 2.60 & 2.71 & 1.81 & 0.76 & 0.42 & 0.58 \\
\hline $\mathrm{CaO}$ & 0.16 & 0.03 & 0.06 & 0.05 & 0.00 & 0.05 & 0.11 & 0.13 & 0.31 \\
\hline Total & 97.03 & 98.62 & 96.56 & 97.09 & 97.01 & 97.43 & 96.20 & 96.27 & 94.37 \\
\hline $\mathrm{RFe}_{2} \mathrm{O}_{3}$ & 21.11 & 27.91 & 41.67 & 41.98 & 47.54 & 42.63 & 37.01 & 31.23 & 43.70 \\
\hline $\mathrm{RFeO}^{3}$ & 50.91 & 48.90 & 38.81 & 39.00 & 36.64 & 40.24 & 43.16 & 45.73 & 40.16 \\
\hline RTotal & 99.15 & 101.42 & 100.73 & 101.30 & 101.77 & 101.70 & 99.91 & 99.40 & 98.75 \\
\hline
\end{tabular}

Notes: $\mathrm{RFe}_{2} \mathrm{O}_{3}$ and $\mathrm{RFeO}$ represent recalculated values based on stoichiometry. $\mathrm{V}_{2} \mathrm{O}_{3}$ corrected for Ti peak overlap. $\mathrm{G}=$ groundmass, $\mathrm{GC}=$ groundmass (core), $\mathrm{GR}=$ groundmass (rim), $\mathrm{PC}=$ phenocryst (core), and phenocryst (rim). 